\title{
BEYOND \\ DEMOCRACY \\ IN CAMBODIA \\ Political Reconstruction in a \\ Post-Conflict Society
}

\section{Edited by Joakim Öjendal and Mona Lilja}

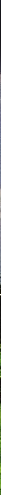


BEYOND DEMOCRACY IN CAMBODIA 


\section{NIAS - NORDIC INSTITUTE OF ASIAN STUDIES DEMOCRACY IN ASIA SERIES}

Series Editor: Tak-Wing Ngo, Sinological Institute, Leiden University

Indonesia and the 'Third Wave of Democratization'. The Indonesian proDemocracy Movement in a Changing World Anders Uhlin

The Cultural Construction of Politics in Asia Edited by Hans Antlöv and Tak-Wing Ngo

Democracy andAuthority in Korea. The Cultural Dimension in Korean politics

Geir Helgesen

Democracy in Malaysia. Discources and practices Edited by Francis Loh Kok Wah and Khoo Boo Teik

Human Rights and Asian Values. Contesting National Identities and Cultural Representations in Asia Edited by Michael Jacobsen and Ole Bruun

Elections in Indonesia. The New Order and Beyond Edited by Hans Antlöv and Sven Cederroth

Democracy, Development and Decentralization in Provincial Thailand Daniel Arghiros

From Subjects to Citizens. Balinese Villagers in the Indonesian Nation-State Lyn Parker

Southeast Asian Responses to Globalization. Restructuring Governance and Deepening Democracy Edited by Francis Loh Kok Wah and Joakim Öjendal

Constructing Singapore. Elitism, Ethnicity and the Nation-Building Project Michael D. Barr and Zlatko Skrbiš

Beyond Democracy in Cambodia. Political Reconstruction in a Post-Conflict Society Edited by Joakim Öjendal and Mona Lilja 


\section{Beyond Democracy in Cambodia}

Political Reconstruction in a Post-Conflict Society

Edited by Joakim Öjendal and Mona Lilja

$\because$ MiaS PRess 
Democracy in Asia, No. 12

First published in 2009 by NIAS Press

NIAS - Nordic Institute of Asian Studies

Leifsgade 33, 2300 Copenhagen S, Denmark

E-mail: books@nias.ku.dk

Online: http://www.niaspress.dk_

(C) NIAS - Nordic Institute of Asian Studies 2009

While copyright in the volume as a whole is vested in the Nordic Institute of Asian Studies, copyright in the individual chapters belongs to their authors. No chapter may be reproduced in whole or in part without the express permission of the publisher.

\section{British Library Cataloguing in Publication Data}

Beyond democracy in Cambodia : political reconstruction in a post-conflict society. -- (Democracy in Asia series ; 12) 1. Democratization--Cambodia. 2. Postwar reconstruction-Political aspects--Cambodia. 3. Cambodia--Politics and government--1975-1979.

I. Series II. Ojendal, Joakim. III. Lilja, Mona. 320.9'596'09051-dc22

ISBN: 978-87-7694-043-0

Typesetting by NIAS Press

Produced by SRM Production Services and printed in Malaysia 
For Ebba, Anna and Ella,

and

Vera, Iris and Kitty 



\section{Contents}

Preface and Acknowledgements • vii

Contributors • ix

Abbreviations • xii

1 Beyond Democracy in Cambodia. Political Reconstruction in a Post-

Conflict Society? - 1

Joakim Öjendal and Mona Lilja

2 Reconstructing Legitimate Political Authority through Elections? - 31 Caroline Hughes

3 The Judicial System and Democratization in Post-Conflict

Cambodia • 70

Kheang Un

4 Decentralization as a Strategy for State Reconstruction in Cambodia • 101

Kim Sedara and Joakim Öjendal

5 Globalization, Women's Political Participation and the Politics of Legitimacy and Reconstruction in Cambodia • 136 Mona Lilja

6 The Political Economy of Aid and Regime Legitimacy in Cambodia • 151

Sophal Ear

7 (Re)Creating Local Political Legitimacy through Governance Intervention? - 189

Malin Hasselskog

$8 \quad$ Cambodian Religion since 1989 • 224

John Marston 
9 Re-establishing Legitimacy through the Extraordinary Chambers in the Courts of Cambodia . 250

Laura McGrew

10 The Never-Ending Hunt for Political Legitimacy

in a Post-Conflict Context • 297

Mona Lilja and Joakim Öjendal

Index • 313

\section{TABLE}

6:1 Royal Government of Cambodia Aid Requests, Donor Pledges and Disbursements • 161 


\section{Preface and Acknowledgements}

It all started at a coffee break, with the rather innocent question of 'How does a community, actually, return to normality after a violent conflict?' Working at a Department of Peace and Development Research, and experiencing the struggles in many societies to overcome past violence, this seemed to be a pertinent, yet under-researched question. The question was put from an anthropological perspective, but was soon scaled up to national level in our joint effort to grasp the full breadth of this issue. An early literature study revealed two things: firstly, few studies had been conducted where reconciliation and reconstruction were dealt with at the same time, and, secondly, although there was much policy-driven and prescriptive literature, there were relatively few full-size empirical studies asking how it had actually been done, and with which consequences. Cambodia seemed to be a primary case for studying these issues. However, at the time, in the late 1990s, there were many cases heading towards a 'post-conflict phase', or so it seemed.

In the context, Cambodia seemed a rogue case: remnants of the civil war still lingering, democracy limping around on one leg, poverty as deep and widespread as before, and political conflicts still manifest, ready to explode. Palestine with an implementable Oslo Agreement, Sri Lanka heading towards a cease-fire, Rwanda forcefully dealing with genocide, and even Bosnia with the fresh Dayton Agreement seemed to make more distinct headway than Cambodia in terms of post-conflict reconstruction. These cases were different yet similar, giving birth to the idea of a comparative research project. While this is a single case volume, it was in this 'Reconstruction and Reconciliation project' that this volume was conceived and nurtured. Thanks to everybody in this project for the inspiration and intellectual support. Especially, we want to thank Marita Eastmond and Helena Lindholm Schulz for generously sharing their intellectual strength and academic experience, setting the standards for a 
work like this. Björn Hettne too deserves credit - this was not his project, but his sheer presence seems to be an inspiration for academic deeds. The volume has also benefited from the Sida/Sarec funded project on 'Hybrid Democracy' and the Processes of Change: the Political Transformation of 'Installed Democracies'.

We are also grateful for a rich variety of comments on the draft of the introduction, mainly from the seminar at University of Gothenburg's School of Global Studies, and from participants at the October 2005 workshop held in Varberg, Sweden, on 'Reconfiguring Religion, Power and Moral Order in Cambodia', organized by Alexandra Kent, who also excellently contributed to language corrections in this book. In the same spirit we wish to thank two anonymous reviewers for insightful and thorough comments. Finally, Sofie Hellberg, Nina Gren and Djordje Zarkovic have done a wonderful job on finalizing the product, and the team at NIAS Press we commend for their patience and support in the critical final stages of this work. An endeavour like this is never finished, and Cambodia continues to surprise, but at some point one has to let it go. Through divorces and complicated pregnancies, this volume has now come of age and is ready to start to live its own life. 


\section{Contributors}

Sophal Ear, Ph.D., is an Assistant Professor of National Security Affairs at the United States Naval Postgraduate School (NPS). Prior to joining the NPS, Dr. Ear was a Post-doctoral Fellow at the Maxwell School of Syracuse University where he taught Policy and Administration in Developing Countries. Over the past decade, he has been consultant for the World Bank, the Asian Development Bank, and others. A graduate of the University of California, Berkeley and Princeton University, he moved to the United States from France as a Cambodian refugee at the age of ten.

Malin Hasselskog is a doctoral candidate in Peace and Development Research at the School of Global Studies, University of Gothenburg. Her research is focused on issues of development and governance interventions, and the interplay that takes place as such interventions are implemented in local settings. From 1997 to 2000 she worked for the UNDP in Cambodia.

Caroline Hughes is Associate Professor of Governance Studies at Murdoch University in Western Australia. She has been researching Cambodian politics for 15 years, and has written two books on the subject, The Political Economy of Cambodia's Transition 1991-2001 (Routledge, 2003) and Dependent Communities: Aid and Politics in Cambodia and Timor-Leste (Cornell SEAP, forthcoming).

Mona Lilja has a Ph.D. in Peace and Development Research and works as lecturer and researcher at the Department of Global Studies, University of Gothenburg. She has previously written about Cambodian women and their different strategies of fighting an uneven distribution of power between men and women within the political sector (Power, Resistance and Women Politicians in Cambodia: Discourses of Emancipation, NIAS 
Press 2006). Currently, she is engaged in a research project on the 'hybrid democratization' in Cambodia.

John Marston is a Professor and Researcher at the Center for Asian and African Studies of El Colegio de Mexico. His work on Cambodia and Cambodian refugees dates back to the early 1980s, when he worked in refugee camps in Thailand and the Philippines. His completed a doctorate in anthropology at University of Washington in 1997. He is the co-editor of History, Buddhism, and New Religious Movements in Cambodia, published by University of Hawai'i Press.

Laura McGrew is completing a Ph.D. at Coventry University in the UK, where her dissertation focuses on reconciliation in Cambodia. She holds Masters degrees from Johns Hopkins University's School of Advanced International Studies in Washington DC, and from Emory University in Atlanta, Georgia. She has worked with the United Nations and various NGOs in Cambodia, on the Thai-Cambodian border, in Rwanda, Sri Lanka, Afghanistan, Nepal and the U.S., in the fields of human rights, rule of law, promoting coexistence, project design, research, monitoring and evaluation. She is the author of several articles on transitional justice, governance and peace building in Cambodia.

Joakim Öjendal is Professor of Peace and Development Research at the School of Global Studies at University of Gothenburg. He has done research on Cambodian issues for 15 years. Currently he is involved in a research project concerning 'Reconstruction of war-torn societies, as well as one on Democratization and decentralization' in Cambodia. His other fields of research have been globalization in Southeast Asia: Deepening Democracy and Restructuring Governance: Responses to globalization in Southeast Asia, NIAS Press, (co-edited with Francis Loh), and regionalization as a global phenomenon in Regionalization in a Globalizing World, Zed Press (co-edited with Michael Schulz and Fredrik Söderbaum).

Kim Sedara is an anthropologist and has an M.A. in Cultural Anthropology, from Northern Illinois University, under the Fulbright scholarship. Presently he is a Senior Researcher at Cambodia Development Resource Institute (CDRI), Cambodia. His research focus is on local government reforms and post-conflict reconstruction of Cambodia and his studies 
have been published in several international journals as well as in edited volumes. During 2009 he is finalizing his Ph. D. at the School of Global Studies, University of Gothenburg.

Kheang Un is currently Assistant Director of the Center for Southeast Asian Studies, Northern Illinois University. He also serves as research advisor to the Cambodia Development Resource Institute and a board member of Build Cambodia, a US-based non-profitable organization, and as an In-Country Coordinator for Tracking Development, a multi-disciplinary and multicountry project, at Leiden University. His publications on contemporary Cambodian Politics are dealing with issues of human rights, democracy, and the rule of law have appeared in The Journal of Human Rights, Pacific Affairs, Asian Survey, Asian Perspectives and in a number of edited books. 


\section{Abbreviations}

ADB

Adhoc

ASEAN

ASEM

ANLWC

BFD

CARERE

CARERE2

$\mathrm{CC}$

$\mathrm{CDC}$

CDP

CG

CGDK

CDHS

COMECON

COMFREL

$\mathrm{CPA}$

CPI

CPIA

CPP

DC-Cam

DED

DPK

DK

DSA

ECCC

FDI

FUNCINPEC
Asian Development Bank

Cambodian Human Rights and Development Association

Association of Southeast Asian Nations

Asia-Europe Meeting

Association for Nuns and Laywomen of Cambodia.

Buddhism for Development

Cambodia Resettlement and Reintegration

Cambodia Area Rehabilitation and Regeneration

Commune Council

Council for the Development of Cambodia

Commune Development Plan

Consultative Group

Coalition Government of Democratic Kampuchea

Cambodia Demographic and Health Surveys

Council for Mutual Economic Assistance

Committee for Free Elections in Cambodia

Country Performance Assessment

Corruption Perception Index

Country Policy and Institutional Assessment

Cambodian People's Party

The Documentation Center of Cambodia

The German Development Foundation

Democratic Party of Kampuchea or the Khmer Rouge

Democratic Kampuchea

Daily Subsistence Allowance

Extraordinary Chambers in the Courts of Cambodia

Foreign Direct Investment

Front Uni National pour un Cambodge Independent, Neutre,

Pacifique et Cooperatif or National United Front for an Independent, Neutral, Peaceful and Cooperative Cambodia 


\begin{tabular}{ll} 
GCDK & General Coalition for a Democratic Kampuchea \\
GDP & Gross Domestic Product \\
GW & Global Witness (NGO) \\
HBF & The Heinrich Böll Foundation \\
ICORC & International Conference on the Rehabilitation of Cambodia \\
IFI & International Finance Institutions \\
IFFRASORC & Institute Français de la Statistique, de Sondage d'Opinion de \\
& Recherche sur le Cambodge \\
IMF & International Monetary Fund \\
KBS & Khmer Buddhist Society \\
KPRP & The Khmer People's Revolutionary Party \\
KR & Khmer Rouge \\
KRT & Khmer Rouge Tribunal i.e. ECCC \\
LDF & Local Development Fund \\
Licado & Cambodian League for the Promotion and Defence of Human \\
& Rights \\
LPP & Local Planning Process \\
MFAIC & Ministry of Foreign Affairs and International Cooperation \\
MoI & Ministry of Interior \\
MoJ & Ministry of Justice \\
MP & Member of Parliament \\
MRD & The Ministry of Rural Development \\
NADK & The National Army of Democratic Kampuchea \\
NEC & National Election Committee \\
PBA & Performance-Based Allocation \\
PDK & Party Democratic Kampuchea \\
PPMC & The Phnom Penh Municipal Court \\
PRK & People's Republic of Kampuchea \\
RCAF & Royal Cambodian Armed Forces \\
RDS & Rural Development Structure \\
REC & Royal Embassy of Cambodia \\
RGC & Royal Government of Cambodia \\
SCM & The Supreme Council of Magistracy \\
SEATO & Southeast Asia Treaty Organization \\
SGS & Société Générale de Surveillance \\
SOC & State of Cambodia \\
SRSG & Recial Representative of the Secretary-General for Human \\
SRP & \\
& Sam Rainsy Party \\
\hline
\end{tabular}


UNBRO The United Nations Border Relief Organization

UNCDF United Nations Capital Development Fund

UNICEF United Nations Children's Fund

UNTAC United Nations Transitional Authority in Cambodia

UNDP United Nations Development Programme

UNFPA United Nations Population Fund

USAID US Agency for International Development

VDC Village Development Committee

VAT Value-Added Tax

WDI World Development Indicators

WFP World Food Programme

WTO World Trade Organization 


\section{Chapter 1}

\section{Beyond Democracy in Cambodia}

\section{Political Reconstruction in a Post-Conflict Society?}

\section{Joakim Öjendal and Mona Lilja}

Cambodia was made one of the paradigmatic cases of the new world order after the Cold War, when superpowers no longer needed regional conflicts, the UN became interventionist, political ideologies became redundant and 'democracy' became a global norm. By this time, Cambodia had already suffered almost three decades of deep conflicts, social fragmentation and political turmoil. The country had existed at the ideological and territorial frontiers of global conflict, while it struggled at the same time with postcolonial dilemmas of independence, identity and modernization. After 1970, when a coup d'etat made obvious the internal tensions in Cambodian society (Chandler 1991) and marked the genesis of the 'tragedy' that was to follow, Cambodia had been experiencing excessive violence and devastating societal destruction. Until 1975, the Lon Nol regime had consisted of a nonlegitimate and incompetent state administration that had further degraded the country's already weak state machinery and made it easy prey for the communist rebels, who subsequently gained infamy as the 'Khmer Rouge'. Although it only lasted until the end of 1978, the rule of the Khmer Rouge meant unspeakable horrors for the vast majority of the population (Kiernan 1993; Chandler 1991; Vickery 1984). The regime was directly or indirectly responsible for a genocide ${ }^{1}$ that may have cost as many as two million lives. In addition, this period saw the breakdown of social order, national infrastructure and popular trust in the state as provider of security and development. 
As the Khmer Rouge regime was approaching dissolution due to its internal contradictions, it was overthrown by a Vietnamese armed invasion in late 1978/early 1979. The new Vietnam-backed regime restored basic order but, following the cruel rationale of the Cold War, the radical communist Khmer Rouge began receiving major support from the Western powers in an effort to counteract the 'expansion' of the Soviet-backed Vietnamese. Hence, an 'unwinnable' civil war ensued and this lasted until the UNTAC intervention in 1992. This story is well known by now and is not the primary interest of this volume.

When the Cold War ended, intense efforts were put into resolving outstanding conflicts and reconstituting Cambodia. The primary mechanism of this was the Peace Agreement of 1991, and the resulting UN intervention known as UNTAC. In an unprecedented manner, the UN 'took over' responsibility for the country, arranged elections and took the lead in drawing up the new constitution. In September 1993, when UNTAC formally left the country, the conflict had supposedly been resolved, a viable political system invented, and a period of democratization and reconstruction was to commence. These processes did not, however, progress in a straightforward way - quite the contrary. It is these processes and the fifteen years following their initiation that constitute the focus of this volume.

'Beyond Democracy' in the title of this volume does not imply that democracy has been achieved in Cambodia. Nor is it meant to suggest that efforts to advance the values inherent in democracy may be discontinued. Rather, it connotes the fact that democracy and democratization have been exhausted as concepts that can be used with any precision to analyse political change and social development in Cambodia. Several cornerstones of the democracy-package have been established, while others have not. Although this is not an uncommon situation in post-conflict ${ }^{2}$ countries, and despite major ongoing social change, this partial democratization may be static rather than a stage of 'democratic transition'. We contend that it is necessary to move beyond debates on democratization and seek an approach that will illuminate shades and dimensions of the process.

Further, in the context of 'post-conflict reconstruction', democratization assumes a particular quality. Being imposed, enforced, inserted and disconnected from the underlying indicators of 'regular' democratization, it becomes atypical and to some extent artificial. Hence, political development in Cambodia over the past fifteen years has been neither 
linear, nor typical, nor predictable. This makes the application of a standard analysis of democratic development inappropriate. Hence, this volume is an attempt to move the frontier of our understanding of post-conflict socalled democratization a step forward. Below, we elaborate the perspective with which we propose to achieve this.

\section{THE APPROACH OF THE VOLUME}

The reconstitution of Cambodia that was initiated in the early 1990s was embedded in two paradigmatic shifts in the international system. These represented early attempts at what has since been termed 'post-conflict reconstruction', and they continue to be important, setting the framework for processes that are traditionally considered 'internal'. The first shift, associated with the end of the Cold War, consisted of changes in power constellations and interests in the international arena. These enabled the acceleration of multi-national interventions designed to repair societies that had broken down in civil wars, genocides and internal strife of the Cold War era (e.g. Snow 1996; $c f$. Ottaway 2003). This also became possible since there were no longer any defining superpower interests being acted out in regional conflicts. The second shift was the global demand for democratization, typically referred to as a 'Third Wave' (Huntington 1991), according to which no other forms of governance were considered internationally acceptable and upon which international aid and political recognition were conditioned (Ottoway 2002). Elections - in which technical aspects were often emphasized - became the policy response and the results became formative for the subsequent process of 're-establishing politics' (Zartman 1995, 2004; Paris 2004).

Unsurprisingly, the 'localization' of these two phenomena - interventionism for post-conflict reconstruction and demands for democratization - in impoverished societies that are emerging from decades of widespread violence, totalitarianism and civil war, and which lack historical experiences of liberal politics, is not a simple process. On the contrary, localization implies enormous social change. It is difficult to achieve rapidly and to control. As Lyons cautiously puts it:

In nearly all recent cases following state failure and civil war, reconstruction of political order has involved elections. Such elections have become the principal means to legitimate the new leadership and the institutional structures that emerge from a peace process. Western policymakers as well 
as parties to conflicts often regard elections as the only alternative on the table'. Such postconflict elections, however, carry tremendous burden.

Lyons 2004: 270

He continues by observing that: 'elections have been used ... to legitimise the new government. [It is] one of the very few mechanisms available to provide internal and external legitimacy to a new government' (ibid., our emphasis). Paris has convincingly pointed out that putting elections before institutions may be tempting in the short run, but devastating in the longer term (2004). The obvious risk here is that elections legitimize a shallow 'democratization', providing an 'acceptable' façade but little substantial change. However, democracy/elections could serve a dual purpose of legitimizing a new regime, ${ }^{3}$ while at the same time providing the battleground for a 'new' political competition, which may retain former dividing lines and possibly re-ignite differences rather than yield reconciliation. In liberal quarters, it is assumed that this process is benign, transforming violent conflict into a controlled, non-violent competition that is battled out in parliament. However, the argument that this is a nonstarter is equally convincing, since the political institutions may not be capable of constraining these differences within the non-violent domain (Hughes 2003; cf. Paris 2004).

There are, in fact, major contradictions embedded in these processes, both between the two trends, and between their conceptual form and actual implementation, implementation being constrained by the history, culture and political interests of each particular case. Firstly, although the two trends observed above are conceptually independent with their own prerequisites and demands, they tend to coalesce in policy: interventions tend to use the toolbox of democratization (and elections) to achieve conflict resolution, but not necessarily democracy. The absence of pre-requisites for democracy has not deterred interventionists from pursuing this strategy. While credible alternatives to democratization as a reconstruction strategy may be few, the ways in which democratization is initiated may, as Paris has argued (2004; $c f$. Mansfield and Snyder 2005), ultimately undermine peace and hamper both reconstruction and the consolidation of democracy itself. Indeed, Ottaway goes so far as to claim that it cannot work on account of its internal contradictions (Ottaway 2002). Similarly, if more modestly, Rondinelli and Montgomery contend: 
Sometimes, in a foreshortened perception of their ultimate goals, nationbuilders support procedures that seem 'democratic', like elections and partisan competition, without concern for their consequences. Experience suggests that these devices introduced too soon can abort stable growth of democratic institutions ...

Rondinelli and Montgomery 2005: 20

Put plainly, delivering democracy through a limited intervention for meeting short-term demands for conflict resolution is usually performed at the expense of long-term processes of democratization ( $c f$. Brinkerhoff 2005).

Secondly, as has been repeatedly pointed out (Thion 1993; Roberts 2001; Öjendal 2003), neither the political culture nor the institutionalized patronage politics of Cambodia (Hughes 2003; Un 2004) are conducive to jump-starting a liberal democracy. The 'big bang' approach to democratization is, in fact, unrealistic for most societies and in particular for those that lack the crucial preconditions that have been identified in democracy research with regard to income level, class structure, democratic tradition, and education ( $c f$. Sørensen 1993; Diamond and Plattner 1998). According to these indicators, Cambodia is far from 'ready' for democratization.

Nevertheless, Cambodia is undergoing change, with the 'old' being affected by liberal democratic discourse and with local variations emerging. However, the outcome is unlikely to match the high ideals of the newborn democracy that guided the UNTAC intervention and subsequent reconstruction support. Instead, we see something else emerging. It is as yet unclear exactly what this is, but it is certainly more open-ended and less linear than what is typically anticipated in the reconstruction discourse. Critics have stressed the fragility of the instrumental approach (Luckham, Goetz and Kaldor 2003; Paris 2004; Junne and Werkoren 2004), and others have illustrated how this fragility is played out empirically in Cambodia (Hughes 2003) and in other places (Chandler 2000). In particular, the significance of the post-violence experience may be underrated (Rothstein 1999). Consequently, intervention/democratization-cum-reconstruction may establish a political system that 'looks good' (especially in terms of elections) but is very vulnerable in the medium to long term. It may have poor credibility, exacerbate political rivalry, be distanced from the masses, fail to gain broad legitimacy and ultimately result in fragmented reconstruction that plunges societies back into uncertainty, insecurity and 
mal-development. ${ }^{4}$ We have seen this happen in countries such as Somalia, East Timor, Liberia, Sierra Leone, Haiti, Congo-Kinshasa and Afghanistan. Indeed, the 'reversal' of early post-conflict reconstruction processes seems now to be the dominant pattern (Junne and Verkoren 2004).

Is the establishment of competitive politics advisable before major conflicts have been solved? Should political rivalry between former enemies be encouraged before there are institutions and systems available to accommodate their conflicts? Long and Brecke have confirmed that the single most important feature of a successful reconciliation process is that the former enemies and leaders of the new political regime publicly reconcile and perform acts expressing symbolic unity and mutual forgiveness (2003; cf. Galtung 2001). Rivalry should, then, only be encouraged in a system in which political differences can be accommodated and when parties are prepared to allow the 'winner' of legitimate elections to rule ( $c f$. Paris 2004; $c f$. Bermeo 2003: 165f). This level of generalized trust is, however, rarely present in deeply divided societies that are emerging from periods of prolonged violence.

Post-conflict reconstruction deals with deep distrust of politics and leadership. Hence, conflict experienced in any civil war implies, by definition, that the ruler's moral right to rule is contested. The reestablishment of a legitimate political system that includes a legitimate government and exercises legitimate governance from a position of strength may be the most central and pressing need in the context of post-conflict reconstruction (Kumar and Cousens 2001). It could be argued that this is indeed a precondition for all other reconstruction efforts, and is what ultimately defines the robustness of the overall process of reconstruction (cf. Rondinelli and Montgomery 2005). While democratization based on intervention does not necessarily render post-conflict reconstruction impossible, it presents major challenges, particularly in relation to the establishment of the 'moral right to rule'. According to the sceptical viewpoint, time is insufficient for the founding of a new system, and newly instated governments are poorly able to meet the external demands made on them. Under these circumstances neither external nor internal legitimacy is easily attainable.

The Cambodian post-war regime has felt the full weight of this. Early on it was regarded as a major success (UN 1995; Doyle 1995) and the government was in extreme need of the assets to which this success allowed access (aid, trade, political recognition, political stability). However, with time, this 
'success' has been increasingly questioned as the contradictions identified above have been seen to impact heavily on the would-be democratization and stabilization process. After the coup d'état in 1997, many analysts were prepared to bury any hopes of successful reconstruction (Ashley 1998; Chandler 1998; Doyle 2001), and after the political turmoil of late 2005, some concluded that democratization had failed in Cambodia (Heder 2005; McCargo 2005). Today, the political situation resembles what Carothers (2002) has branded 'dominant power politics'. The political opposition has been effectively marginalized and most observers consider a change of government through election to be unlikely within the foreseeable future (e.g. SPM 2003), though the situation does not constitute 'dictatorship' as we know it. Carothers elaborates:

Countries with this syndrome have limited but still real political space, some political contestation by opposition groups, and at least most of the basic institutional forms of democracy. Yet, one political grouping ... dominates the system in such a way that there appears to be little prospect of alteration of power in the foreseeable future.

Carothers 2002

More particularly, since heavy external interventions and hollow democratic procedures may produce a government with only limited legitimacy, any legitimacy that is achieved may in fact be based on predemocratic conditions or contemporary patronage politics. In other words, traditional patrimonial politics may dominate the system from within ( $c f$. Craig and Porter 2006; Pak et al. 2007). The key challenge to progressive policymakers for achieving political stability in such a context may be to support politics promoting legitimacy based on a democratic system. However, although democracy advocates would like to believe this is possible, it is not clear that pursuing democratic politics is the most rational choice in the short term for those actually in power.

The dominant party in Cambodia has been walking a tightrope since 1993. On the one hand, constitutionalism and democratic rules have been partly upheld, human rights abuses have decreased and civil liberties have been protected sufficiently to secure continued international support, aid flows and a degree of 'external legitimacy'. On the other hand, state-led exploitation, political violence, corruption and politics based on personal networks have far from vanished, and the result is an internal legitimacy crisis. The CPP-led government has remained, indeed established itself 
in power, but it has neither enhanced regime legitimacy, nor deepened democracy (Un 2004; Hughes 2003; Hughes and Kim 2003). For whatever reason - the UNTAC legacy, unresolved conflicts among the political elite, structural impediments, persistent patrimonial politics or an imperfect constitution - the aftermath of each national election has occasioned the questioning of the right to rule and has resulted in prolonged national crises. Moreover, open political violence, widespread corruption, and stateled exploitation of natural resources have led to popular discontent with the current regime. However, voters may remain loyal simply for lack of a viable alternative.

Popular engagement in, or defence of, the democratic ('electocratic', some would say, $c f$. Shamsul 2002) system has been weak during the period in question (Colletta and Cullen 2000). Despite popular support for the idea of democracy, the widespread optimism at the time of UNTAC has been replaced with cynicism from former believers and indifference from the masses. Donors, including influential international financial institutions such as the World Bank and the IMF, have repeatedly threatened to withdraw support as have some bilateral donors. Both internal and external legitimacy are, then, deficient though they may not be entirely destroyed (see below). It would seem that the most pressing task of the reconstruction phase - the establishment of a political system that delivers a regime with the moral right to rule - is on the verge of failing and propelling Cambodia back into political turmoil. If this were to occur, it would not be due to an unexpected outbreak of violence as on previous occasions but to diminishing legitimacy, paradoxically resulting from the 'success' of the dominant party in amassing political power. Clearly, 'elections' and electoral politics have not in themselves managed to prevent this.

It is tempting to discuss how to enhance legitimacy, fulfil the ideals of democracy, achieve reconstruction and to write about how things should be done. However, this kind of writing is common in the post-conflict reconstruction literature (Orr 2002; Hamre and Sullivan 2002; World Bank 1998; Rondinelli and Montgomery 2005; Ottaway 2002) and more is hardly required here. Instead of a normative-idealist approach, we therefore apply a more analytical-constructivist one based on empirical material and using a 'from within' perspective. ${ }^{5}$ Instead of analysing how reconstruction and the regaining of political legitimacy should have been achieved, we ask the empirical question: what has been done to rebuild legitimacy? And we ask the analytical question: has this actually resulted in enhanced 
regime legitimacy? The fundamental line of inquiry, which takes structural constraints and actors' (mis)behaviour into consideration, concerns the way in which societies actually behave politically in their attempts to recover order after periods of internal and excessive violence. ${ }^{6}$

We are primarily interested in the period from the UN intervention and the subsequent election in 1993, up to the present. Taking a critical stance upon instrumental interventions aimed at achieving conflict resolution and upon the belief in the implementation of democratization, we examine the reconstruction efforts that have taken place in the case of Cambodia. In particular, we are interested in how a re-established political regime may or may not earn the moral right to rule. This is particularly interesting in the Cambodian case in which this 'moral right' has historically been substituted by 'power' (Mabbett and Chandler 1995) and where stateled large-scale violence and civil war have undermined political unity, government authority and the generalized trust that is essential for stable social conditions. This lack of trust is extended to politics and the political system (Hughes and Kim 2003; Luco 2003; van de Put 1997).

Thus, reconstruction in Cambodia has been attempted under the mantle of democratization. It was born of external intervention and suffers the legitimacy problems that, we argue, inhere in such an arrangement. However, the question as to whether or not political reconstruction progresses remains an empirical one. In the Cambodian case, we focus upon whether or not the (re-)establishment of a political system is associated with basic and widespread legitimacy. We inquire into whether the inserted political system can be transformed from a device for managing conflicts into a substantial democracy with broad-based participation, reliable institutions and civil norms that are able to accommodate political conflicts. We propose that to manage this, a democratic system needs first to be gradually developed so as to enhance political legitimacy so that a more genuine, institutionally fully-fledged political system with democratic qualities can eventually emerge. Such an approach makes simple questions about whether or not Cambodia qualifies as a democracy redundant. Our inquiry deals instead with the ways in which democratization may or may not be emerging in Cambodia. 


\section{THEORETICAL UNDERPINNINGS}

The rationale behind the international approach to the Cambodian case is deeply embedded in liberal theory and its assumption that democracy digests conflict ( $c f$. Richmond 2005). It is assumed that Cambodia's postconflict difficulties will be addressed by introducing a formal democratic system and its standard techniques. It is also assumed that democratic values will gradually develop in tandem with this, and that respect for human rights will improve and political institutions be strengthened. This is then supposed to draw society into a virtuous cycle of deepening democratic values. Even when the techniques of a democratic system are in operation, the quality of democracy hinges on the localization of politics and the generation of legitimacy for the emerging regime. In other words, we propose that the reconstruction urgency is the problem to which democratization is the measure applied, for which legitimacy is the 'quality indicator' for assessing the 'realness' of Democracy. Hence, these three concepts - reconstruction, democracy/democratization, and legitimacy - are of paramount importance for this work. Below, we present these concepts in general terms before explaining how they will be applied in this volume.

\section{The general and particular application of 'reconstruction'}

The declaration by UN General Secretary Boutros Boutros-Ghali in 1992 of the need for global 'Peace-Building' in the aftermath of the Cold War seemed timely. He proposed this should include: 'disarming', 'restoration of order', 'repatriation of refugees', 'retraining of security personnel', 'monitoring of elections', 'increased human rights monitoring', 'reformation of government institutions' and 'promotion of formal and informal ways of political participation' (UN 1992). More than a decade later, while this list of 'virtues' has in many places largely been achieved, social stability and reconstruction have not; nor has the risk of returning to a situation marked by violent conflict and endemic under-development been reduced. The most obvious explanation for this may be that the UN Secretary General was thinking in terms of time-limited interventions and projects for addressing the most urgent problems, while little attention was paid to the particulars of post-conflict target societies and their historical and cultural legacies. This has been the dominant approach to recovery for a 'decade of reconciliation' (cf. Chandler 2000; Roberts 2001). 
However, debate about the approach, content and meaning of 'reconstruction' has blossomed. As a theoretical concept, reconstruction is poorly defined and is influenced more by political, ideological and pragmatic preferences than by analytical clarity. In this volume, we present it as the process by which a society attempts to move from a situation marked by earlier conflict to a situation in which this legacy is no longer a defining feature. In the research proposal upon which this research is based, ${ }^{7}$ we proposed four broad fields as integral to 'post-conflict reconstruction'. These were: the re-establishment of legitimate political authority; the transition to a post-war economy; the achievement of reconciliation between former enemies; and the creation of 'home', including the return of refugees. In this volume, we focus on the first of these fields.

The World Bank, with almost a decade of experience of 'Post-conflict Reconstruction' (or six decades if we consider its origin in Europe after the Second World War), defines it as 'the rebuilding of the socio-economic framework of society' and the establishment of 'the enabling conditions for a functioning peacetime society [including] the framework of governance and the rule of law'. The UNDP, whose work is guided by the Security Council's statement of February 2001, perceives 'peace-building' as 'aimed at preventing the outbreak, the recurrence or continuation of armed conflict and [it] therefore encompasses a wide range of political, developmental, humanitarian, and human rights programmes and mechanisms' (UN 2001). ${ }^{8}$ These views are of course permeated by their respective internal culture and mandate, but are nevertheless (or precisely therefore) dominant in terms of financing activities for post-conflict reconstruction, and they are thus of great significance for any post-conflict assessment.

Turning to the explicitly policy-oriented literature, in a push for a reorientation of the US after September 11, Hamre and Sullivan, for instance, propose 'security', 'justice and reconciliation', 'social and economic well-being' and 'governance and participation' as the four pillars on which any post-conflict reconstruction must build (2002: 89). Orr, in a critique of an all too common, distant, 'minimalist' approach to reconciliation, proposes that in order to achieve longer-term sustainability, five areas must be considered: 'supporting "constituting processes"', 'mobilizing disenfranchised sectors of the population', 'building sustainable civil administration capacity', 'addressing corruption', and from the side of the donor community 'crafting an appropriate system of conditionalities' (Orr 2002: 141-142). 
These are examples of a literature that is replete with 'lists' of what to do in a 'post-conflict' situation. They often produce policy-driven recommendations designed for the consumption of intervention strategists and aid policy-makers. Such recommendations are imbued with unacknowledged ideological preferences and they frequently lose sight of the society to be reconstructed, in all its social and cultural complexity. ${ }^{9}$ The above-listed recommendations are undeniably desirable to various degrees for the reconstruction of society. In particular, an acceptable political order has to be founded, consisting of constitutive processes as well as administrative capacity ( $c f$. Barnes 2001: 86).

However, the 'policy lists' reviewed above are inadequate for at least four reasons. Firstly, most of this literature shares the presupposition that the trajectory of reconstruction is the progressive return to a vaguely defined, pre-existing state of normality. We consider this presupposition ill-founded since the 'previous situation' was, at least partly, the reason that conflict broke out in the first place ( $c f$. Brinkerhoff 2005: 11; Jackson 2005: $56),{ }^{10}$ and current political and economic globalization have also put new pressures on individual states compared to the 'golden era' of nation-state building, which coincided with the decolonization period (Debiel and Klein 2002: 5; Lizée 2000: 163ff). Cerny has coined the term 'governance gap' to capture weakening state sovereignty as increasing numbers of decisions are taken far from the local setting (1999). In an era of globalization, we can take neither the forms nor the processes of the road to reconstruction and reconciliation for granted; the re-establishment of political authority may take unexpected turns ( $c f$. Weiss 2000; Öjendal 2002). Seen historically, the establishment of multi-party and participatory democracy in Cambodia, for instance, and the attempt in this way to bolster regime legitimacy were bold inventions ( $c f$. Mabbett and Chandler 1995). 'Reconstruction' is a search for a brave, though not always recognizable, new world.

Secondly, the concept of 'Post-Conflict Reconstruction' also suffers from its association with rehabilitation after natural disasters (which has a longer history in terms of international intervention), the assumption being that we know what to rebuild so we only have to think about how to do it (Green and Ahmed 1999: 190; $c f$. UNDP and UNFPA 2000). We know how to reconstruct a bridge, but to (re)construct political institutions in an era of neo-liberal globalization when there is an urgent need to re-establish state authority and regime legitimacy in a tortuous political culture is not simply a technical task. Obviously, when collapsed states are given a 
second chance, they should be prevented from heading down the same path again. Rather, the remarkable feature of current reconstruction efforts is that we do not know what to 'rebuild'. However, it is safe to assume that reconstruction must be informed by the complex reality and micro-politics of the local setting. Current reconstruction efforts must therefore both 'invent' and rehabilitate society (Migdal 2001; Schurman 2001; Öjendal 2002; Newell 2002; Weiss 2000). Thus, the 're-' component of reconciliation and reconstruction may be misleading.

Thirdly, in some of the literature it is argued that in order to overcome past violence, the nature of the conflict must be analysed and understood. For instance, a conflict arising from ethnic tensions requires resolution that emphasizes communication and integration, while a class-based conflict may require a changed distribution of resources and increased transparency. Galtung, among others, argues that 'Resolution' is often simply taken for granted in the Reconstruction and Reconciliation debate; it is the missing ' $R$ ' of a triad (Galtung 2001). This position is further developed by Long and Brecke, who argue that a conflict cannot be considered resolved until there has been some kind of reconciliation between the key actors of the former conflict (2003). Despite common political rhetoric, there exists no 'Ground Zero' - all change emerges from a previous situation and is therefore in some way dependent on that situation ( $c f$. Skocpol 1984). Reconciliation follows from conflict resolution, which in turn is designed according to the basis of the conflict. Often, little attention is given to actually solving the conflict. Hopes are instead pinned to the emerging political regime and some distant promise of 'development'. This may explain the notable lack of sustainability that characterizes post-conflict processes ( $c f$. Verkoren and Junne 2004).

Fourthly, as should be clear from the above, most lists and recommendations are steeped in culture, ideology and the 'fashions' of the international donor community. Moreover, they are typically prescriptive policy recommendations that seldom stem from empirical analyses (even less so from 'research') of how societies have gone about recovering themselves, and they are often delivered without reference to specific political cultures or social organization: neither institutional nor legal conditions are normally considered (World Bank 1998; Colletta and Cullen 2000; UNDP 2002, are cases in point). 'Normality' is then defined according to a hegemonic discourse and may be anything but 'normal' for the particular case. ${ }^{11}$ Thus, reconstruction efforts are assumed not only to be identical irrespective of 
where they are implemented, but also to be of a pre-determined character. We propose, by contrast, that social interests need to be identified, political activities analysed and cultural parameters discussed.

There is no way of determining beforehand how long a process of 'reconstruction' will take, though a generation is a common estimate. However, the quality of the process is more important than the duration. In one decade, South Africa seems to have come much further than Chile has in three and Turkey in nine. Moreover, there are few examples of excessive violence being overcome without some kind of public, focused reconstruction-cum-reconciliation effort. ${ }^{12}$ A century later, the large-scale violence against the Armenian population remains a contentious issue in Turkey due to official refusal to acknowledge its significance. In Cambodia, we have many shallow, technical measures being aimed at reconstruction and reconciliation, but few have succeeded in initiating the abovementioned transformation. Today, 39 years since Sihanouk was overthrown, 31 years since the Khmer Rouge was ousted and 16 years since the UN introduced 'democracy', there is still an urgent need for reconciliation and reconstruction in Cambodia.

The major exception to this pattern is the imposition of a democratic system, which, according to liberal theory, is expected to embed reconstruction efforts in an overall political progression (cf. Paris 2006). However, given the 'imposed' nature of 'democracy' in Cambodia (and other similar cases), it is far from certain that it will manage to achieve this ( $c f$. Lyons 2004). The pressure for the democratic system to deliver a wide range of goods under precarious circumstances is enormous. Hence 'democracy' and 'democratization' become key concepts for 'reconstruction'.

\section{The general and particular application of 'democracy' and 'democratization'}

An impressive body of literature has evolved in the wake of Huntington's 'third wave of democratization' (Huntington 1991; Diamond 1999; Hadenius 1997; Diamond and Plattner 1993, 1998; Sørensen 1993). However, the halting nature of these 'democratizations' has spawned a trend for attaching prefixes to democracy such as 'semi-', 'electoral', 'quasi-', 'liberal', 'illiberal', and 'shallow'. Whereas in the 1990s much focus was placed on democratization (i.e. transition from authoritarianism), interest has now shifted largely to the consolidation of the shaky democracies that usually result from interventions (Diamond 1999; cf. Öjendal and Antlöv 1998). 
One of the most illuminating distinctions is perhaps that between, on the one hand, 'procedural' democracies, or the establishment of multiparty elections and associated structures and liberties and, on the other, 'substantial' democracies, or the deeper aspects of societal development conducive to democratization (Gordon and White 1998; Bastian and Luckham 2003). For instance, in the early 1990s in Africa, virtually all authoritarian systems turned into 'procedural' democracies in just a few years, only rapidly to revert to quasi-dictatorships or one-party states, sometimes accompanied by civil wars. By contrast, criticism of the sluggishness of democratization in Korea and Taiwan has virtually died out in light of the consistent increase in democratic substance in these political systems. For these, consolidation has become a key term. The establishment of procedural/electoral democracy is really the easy part, but consolidating it is more problematic. ${ }^{13}$ Some argue that consolidation has largely come to a halt and they brand the emerging political systems as at best 'hybrid', since they have crystallized into a mix of authoritarianism and procedural democracy (Carothers 2002). We will elaborate this point below and in the concluding chapter of this volume.

In studying the role of democracy in post-conflict reconstruction the most striking paradox seems to be the tight focus on enforced democratization, while the vast literature on 'spontaneous' democratization remains absent from the discussion. Or as Call and Cook note: 'The postconflict peacebuilding community and the democratization communities have enjoyed remarkably little dialogue' (2003: 136). They go on to observe that most cases of intervention-cum-democratization do not tally at all with the structural requirements for democratization designated by democratization researchers ( $c f$. O’Donnell et al. 1986; Sørensen 1993; Diamond 1999). This kind of intervention fits neither with 'traditional' theory about the democratizing effects of a growing middle class (Lipset 1959) or the revolutionary power of the working class (Therborn 1977), nor with notions of the transforming power of 'pacts', as advocated by O'Donnell and others (1986). Instead, intervention is often founded upon vague theoretical grounds that combine a variation of liberal peace theory (cf. Richmond 2005) with assumptions about the influence of the prodemocracy international context. The strength of this combination is far from evident. Hence, we fear, these interventions seem destined to yield unstable democracies for which the problems of substantiating democracy 
and regime legitimacy remain key. In the light of this, some challenging questions have been posed by Call and Cook:

[Does postconflict democratization] signify a failure of the international community because of either insufficient resources or poor choices? Or are Western models of liberal democracy simply an inappropriate model? Conversely, should partial success be emphasized, recognizing that many years are required for democratic consolidation and that expectations should be lowered?

Call and Cook 2003b: 234

The reversal of perspective in the middle of the quote above is crucial - this may be the only way to combine the practice of intervention with the theory of democratic transition without rejecting such a combination as a policy recommendation. However, this requires that we acquire a 'sense of direction', i.e., is the installed regime - which, we suggest, typically suffers from a structurally determined legitimacy deficit - progressively gaining legitimacy and stability, and is it slowly developing a more substantial democracy? Or is 'democracy' just a veil that in fact legitimizes authoritarian politics and impedes 'real' democratization? In his extensive writings on democratic transition, Diamond argues:

At bottom, I believe consolidation [of democracy] is most usefully construed as the process of achieving broad and deep legitimization, such that all significant political actors, at both elite and mass levels, believe that the democratic regime is the most right and appropriate for their society, better than any other realistic alternative they can imagine.

Diamond 1999: 65

Diamond's reasoning resonates with the approach taken in this volume. However, it also reveals one of the most critical flaws in much of the democratization literature. In Cambodia most people 'believe that the democratic regime is the most appropriate for their society', but the real question (in Cambodia and elsewhere) is whether this 'democratic regime' is 'democratic' in any meaningful way. The distinction between what is branded 'democratic' and what is actually delivered is central to this volume. We therefore need to 'unpack democracy'.

Here, we shall be assessing the processes and fields that have the potential to enhance (or reduce) regime legitimacy. Legitimacy thus becomes the key concept for unpacking of the notion of democracy: Its growth or decline 
becomes a litmus test for evaluating the success of political reconstruction. Greater popular confidence in the emerging political system is therefore assumed to indicate a gradual move out of post-conflict emergency. We choose not to attach a 'cover all' prefix to the concept of democracy in order to discuss whether or not Cambodia qualifies as such a democracy. Instead, we propose what we believe to be a more robust and in-depth approach to the understanding of the possible consolidation of democracy and to postconflict reconstruction.

\section{The general and particular application of 'legitimacy'}

Past experience suggests that what may be needed most [in post-conflict reconstruction] is some degree of political stability and legitimacy and respect for law.

Rondinelli and Montgomery 2005: 20

In a Weberian perspective, any government or ruler requires a degree of legitimacy in order to rule, and any sustainable political system must be able to deliver this. 'The basis of every system of authority, and correspondingly of every kind of willingness to obey, is a belief, a belief by virtue of which persons exercising authority are lent prestige' (Weber 1964: 382). This view of legitimacy is in turn based on the notion of a reciprocal relation between people and state, like that of the classic Hobbesian 'social contract'. The state provides protection and people reciprocate with loyalty, paying taxes or enlisting to fight external enemies. Moreover, according to the same logic, the basis on which a regime earns its legitimacy determines which power it can exercise (Weber 1964). Without popular support, a ruler who lacks the moral right to rule can only dominate through the crude exercise of power such as in the form of coercion, violence or fear. In Cambodia, such conditions have recurred in various guises over the last three decades, most brutally during the Khmer Rouge era in the 1970s. A modern liberal democratic regime cannot operate without legitimacy - it will either be voted out of office or transform itself into a manipulative authoritarian system to retain power. However, the Cambodian context exhibits further complexities, particularly within two areas.

Firstly, during the Westphalian era, ${ }^{14}$ in which Weber rested comfortably, the ruler and the subject were locked into mutual dependence, creating a solid bond from which neither could escape. However, under neo-liberal globalization, it is clear that legitimacy has to be earned internally as well 
as externally - particularly for weak states that depend on aid and trade ( $c f$. Lyons 2004; cf. Alagappa 1995: 48). In the case of Cambodia, this dual source of legitimacy is very evident. Virtually no taxes are collected in the rural areas, but the financial flows (aid, trade, FDI, resource concessions, exports) from the outside keep the system afloat. This represents a remarkable shift from the historical rice-based, self-sufficient economy (cf. Öjendal 2003). Secondly, civil war is, as noted, by definition a condition in which the legitimacy of the ruler has been called into question. Unless there is some exceptional transformation (like that in Spain in 1975), a legitimacy deficit will persist, even under positive conditions, among major segments of society for some time. Unless this is dealt with effectively, old conflicts are likely to flare up and re-ignite civil strife. As Brinkerhoff remarks: 'Without a minimum degree of legitimacy, states have difficulty functioning; and loss of legitimacy in the eyes of some segment of the population is an important contributor to state failure' (2005). Given the patrimonial political culture and historical distance between rulers and ruled in Cambodia (Pak et al., 2007; cf. Mabbett and Chandler 1995), the notion of governments earning legitimacy based on popular support in a democratic process and seeking 'power' from below is novel. Indeed, 'post-conflict' political change has robbed rulers of the 'regular' mechanisms of generating legitimacy.

The liberal aim of democracy, and elections in particular, is to produce legitimate governments. However, this may not always succeed. Indeed, legitimacy may be enjoyed without elections (such as with the government of Sweden during the Second World War), and elections may not deliver legitimacy (as in Eastern Europe in the 1980s). In post-conflict societies, individual and collective trauma from earlier violence may override the significance of elections and the 'burden' on elections may simply be too high for them to guarantee the production of legitimate governments (Lyons 2004). Peasants who cast votes on election day may see no results but may instead face insecurity if they dare to challenge local norms; women may be invited to join various political bodies but may be punished if they dare to speak up; the 'rule of law' may be applied unfairly and become an instrument of the powerful; opposition parties may exist but can become impotent due to marginalization or veiled threats. Major social categories have only limited access to democratic rights through national elections alone. Hence, the building of legitimacy is a multi-dimensional process that involves a wide range of 'political goods'. 'Reconstituting legitimacy in the post-conflict states', Brinkerhoff argues (2005: 5), 'involves 
expanding participation and inclusiveness, reducing inequities, creating accountability, combating corruption, and introducing contestability (elections).' According to the same source, legitimacy-building also includes service delivery, constitutional reform, re-establishment of the rule of law and functioning institutions, as well as civil society development. It is in line with this understanding that this volume presents a 'state-of-the-art' analysis of a broad spectrum of Cambodian society in order to see to what extent 'legitimacy' is generating 'democracy'.

Ultimately, 'legitimacy' is an 'essentially contested concept'. It defies definition since it denotes evaluation as well as description (Gallie 1956). Degree (strong/weak) is more relevant than absolute dichotomies and qualitative assessments are more fruitful than quantitative measurements (cf. Alagappa 1995: 30). It is therefore and should be subject to constant evaluation and reassessment. Typically, 'democracies' that are put in place via international intervention have the challenging task of mediating between pre-existing systems and norms (such as traditional governance systems, habituated war-rationalities, pre-modern institutional set-ups, gender orders and centralized power structures) and external demands for a rights-based, election-steered, participatory, transparent and liberal democratic order. In the short term, governance delivered by the elite may consequently be legitimized through adherence to local and traditional ideals rather than to those of liberal democracy (Jackson 2005). In other words, the elite is likely to continue seeking its power base according to the pre-democratic social order, and to act according to this rationale and within its local network despite the fact that its power base is supposed to derive from the popular vote. This situation can give rise to an external legitimacy crisis instead, which may ultimately be devastating for those promoting a stable internal political reconstruction. ${ }^{15}$ However, the reverse is also true - that hastily abandoning the traditional system in favour of a foreign one may give rise to an internal legitimacy crisis instead. Many of the regimes that are emerging under these circumstances try to attempt both; using elections to secure external legitimization and patronage politics for securing internal power. ${ }^{16}$

Clearly, in post-conflict societies elections may not carry the same constitutive value that they do in other contexts. The pursuit of legitimacy is a more comprehensive and drawn-out endeavour than the mere holding of elections (Bastian and Luckham 2003: 21; Brinkerhoff 2005: 12). At root, we contend, legitimacy consists of three components. Firstly, it requires 
that actions are based upon a legal framework, ultimately a constitution, but in a wider sense on the establishment of the rule of generally accepted, known and implemented law, for which government 'impartiality' is essential (Rothstein 2005). Secondly, to achieve regime legitimacy, credible, sustainable and accountable political institutions must be created ( $c f$. Paris 2004). Thirdly, to enjoy regime legitimacy, a degree of popularity must be mustered, possibly drawing upon the 'sanctity of tradition' (Weber 1964: 130ff).

Historically, Cambodian rulers have not sought legitimacy in this way (Mabbett and Chandler 1995). Instead, 'force' rather than a moral right to rule has generated capacity ( $c f$. Ovesen 2004). However, in combination with crude power the 'sanctity of tradition' has offered royalty a right to rule and the Sangkum era ${ }^{17}$ undeniably contained some dimensions of legitimization as outlined above. However, without exception (including the Sihanouk-era), rulers have been forced to employ violence in order to retain power. Under a democratic order, other means - another mixture of popularity and patronage - of securing legitimacy have to be sought and this has presented a major challenge to post -1993 governments.

At present, we lack the historical or cultural experience of how political systems emerge and how their key agents act under the imperative to generate political legitimacy and extend accountability downward. Liberal theory may prove to be correct or it may not, either way greater credit should perhaps be given to cultural and/or structural explanations. New solutions may, as this volume proposes, instead appear as an unpredictable mixture of 'sanctity of tradition' and 'forced liberal democratization', yielding a 'hybrid system'. This volume aims to shed light on this 'hybrid' pattern. Below, we briefly present the volume's empirical content and contributors.

\section{THIS VOLUME: A BRIEF PRESENTATION}

Plenty has been written on the pros and cons of the UN intervention in 1992/93 (e.g. UN 1995; Finlay 1995; Doyle 1996) and on the legacy it left (Ashley 1998). However, the UN operation has been assessed either in terms of its actions and choices within its narrow mandate, with little reference to what this meant for social change, or according to the supposition that everything that has taken place since is the responsibility of the UN operation, while little attention has been paid to the credibility of this 
external agent. Metzl early identified the dilemma of delivering a balanced assessment of the intervention:

Whatever the future holds for Cambodia, it is unlikely that historians will care much that UNTAC caused inflationary pressure in Cambodia, that prostitution, evil though it is, increased under UNTAC's watch, or that the de-mining programme was begun. If Cambodia remains relatively stable and slowly develops economically and structurally, later generations will praise the UN's role in Cambodia with the type of optimistic gloss that characterizes the Blue Book. If, on the other hand, the country falls apart, few will care that the refugees were returned, that there was a period when individual rights were somewhat protected, or that technically excellent elections were carried out.

Metzl 1995

It may, then, be time to seek to better understand the value of intervention and enforced democratization as a means of reconstructing societies after periods of internal strife and violence. As social scientists, we are not primarily interested in evaluating the UN but rather in studying an emerging political economy in order to understand to what extent a new regime has managed to re-establish political legitimacy. We seek indications of more solid democratic conditions than those that can be produced by 'simple' elections. The garnering of legitimacy is a multifaceted and drawnout process that cannot be contained within the confines of a UN operation or be captured with simple measuring techniques. We have chosen to study a number of key fields for illuminating this process.

Caroline Hughes offers an historical overview of the elections and contesting parties to explore the extent to which these have managed to move beyond the political conflicts inherited from the last three decades, while at the same time fulfilling their democratic task. Although the 'intervention model' (Ottaway 2002) suggests that elections are supposed to achieve all of this, it is far from certain that they do so in reality.

This is followed by a chapter by Un Kheang, in which he assesses the extent to which the rule of law has been introduced and whether this has generated broad legitimacy. The constitution is one of the most liberal in Asia, and the development of new laws accepted by the democratically elected parliament has been intense, but the drafting and implementation of laws is not unproblematic. The author contends that this may be one of the weakest points in the Cambodian post-conflict political reconstruction. Another rearrangement of the state administration 
that is designed to enhance popular participation and regime legitimacy is the decentralization reform, which has become a mixture of local democratization and development intervention. This is one of few reforms that has been driven from within the state in the era of reconstruction, and may be just the beginning of a major reform package. ${ }^{18}$ This is discussed in the chapter by Kim Sedara and Joakim Öjendal, who examine how the local state machinery has strengthened itself and, thereby, the current political system.

A major paradox in post-conflict Cambodia is that at the time of the UN operation, although women comprised an overwhelming majority of the population, they were nevertheless politically marginalized. A core ideal of democracy is that everybody should have equal political rights. If the majority of the population is able to participate in a new political system it is likely that legitimacy gains can be made. However, in Cambodia it seems this process has not been as smooth as was hoped because of the 'sanctity of tradition'. Mona Lilja assesses the process by which women enter politics, the shortcomings of this process and the possible political consequences. The two subsequent chapters review similar issues but in entirely different ways. In classical social science, the ability to deliver prosperity or 'growth' is considered the single most effective way of enhancing legitimacy ( $c f$. Alagappa 1995: 41ff). Aid flooded Cambodia after the first elections, and has continued to do so. But the question remains as to whether or not this has this generated growth, reduced poverty and been turned into political gains and, if so, by which means? Have the conditionalities attached to foreign aid been a source of regime strength or regime weakness? These questions are addressed by Sophal Ear. The second contribution analyzing the dynamic effects of foreign long-term intervention is provided by Malin Hasselskog. She discusses to what extent donors, through the design of aid projects, might achieve a desired alteration in local politics and promote the establishment of 'good governance'. The micro-context she presents in her contribution shows that interventions are not so easy to 'control' and it is not easy to make them deliver what they are supposed to. Instead they tend to gather their own momentum and evolve in unexpected directions, influenced by local circumstances. The state may be strengthened by aid but may, equally, be undermined by it. This theme recurs in Ear's contribution.

Finally, we have two contributions concerning key processes of reconstruction. The first, by John Marston, assesses how religion has 
become involved in the legitimization of the new order. The relationship between the Sangha (brotherhood of monks) and the political ruler has always been important in Cambodia, and perhaps particularly so in the post-independence era. After its abolition by the Khmer Rouge, Buddhism is now regenerating, but it stands in a complex relationship to political power. Political actors are, of course, keen to cash in on the legitimacy that Buddhism can generate, but are not necessarily as keen to be restrained by its ethical norms and values. In the last chapter, which is of great contemporary relevance, Laura McGrew analyzes the political significance of the design and preparation of the Khmer Rouge Tribunals. The South African Truth Commission is frequently given credit for that country's relatively successful post-conflict reconstruction. The Khmer Rouge Tribunals are an entirely different phenomenon, although they are not necessarily less politicized. The government is ambivalent to the trials, since it could very well see several of its prominent members or connections summoned to court. How could this be avoided without the reconciliatory value of the trials being nullified? How could legitimacy be gained rather than lost in this process?

Finally, we provide a concluding chapter on today's Cambodian political reconstruction-cum-democratization. Our focus is on whether, how, why or why not political reconstruction in Cambodia progresses through its alleged democratization. To assess the degree and pace of this multifarious process we observe to what extent the current regime is managing to reduce the legitimacy deficit that emanates from intervention and enforced political change.

Although the contributors to this volume address differing areas of study, methodologically we all seek to provide 'empirically thick' descriptions that present a perspective 'from within'. This is in contrast to the perspectives 'from above' or 'from outside' that accompany the usual lists of policy recommendations. Our key tasks are observation and analysis rather than prescription and recommendation. All chapters in this volume are based on extended empirical fieldwork and long-standing acquaintance with the Cambodian context. We cannot give the final answer to the question of the degree of legitimacy enjoyed by the current regime, but we provide well-founded input to the debate on how to view the process of reconstruction after organized violence and the re-establishment political authority under these conditions. We also contribute to the ongoing debate about democratization in Cambodia, not by arguing about whether or not 
Cambodia is a democracy, but by illuminating the underlying weaknesses and strengths of the current political system and the roles of its prime actors. Finally, we discuss some of the theoretical issues raised by the Cambodian case and in so doing illuminate discussions on democratization.

\section{NOTES}

1 There is debate regarding the technical content of the term 'genocide'. Here, however, we use the term in a generic sense.

2 We use the term 'post-conflict' since this is the concept discussed in most of the relevant literature. However, it is to some extent a misnomer since societies rarely move beyond 'conflict' - conflict being a normal feature of any society. A more accurate concept might be 'post-war' or, more broadly, 'post-violence'.

3 In accordance with a generally accepted approach (Lawson 1993), we distinguish between the legitimization of the State, of the Regime and of the Government. The first represents overall state construction and support for whether there should be such a construction within the given territory or not. The second would be support for the political system in question; i.e. its basic values and political institutions. The third would be support for a particular government in power at any particular time. Henceforth, this distinction will be used in the text. However, it should be noted that socialist and authoritarian politicians intentionally blur the distinction between these categories. At times, a fourth level may be added, namely a personalized one, epitomized by the Leader.

$4 \quad$ Mansfield and Snyder (2005) have provided a powerful contribution to the 'democratic peace' debate when noting that although mature democracies may be stable, 'emerging democracies' are more unstable than either mature democracies or authoritarian constructions ( $c f$. Richmond 2005).

5 In this, we agree with, and respond to, Call and Cook: '[the post-conflict reconstruction] literature has been ... empirically weak, and highly prescriptive' (2003: 235).

6 This question constitutes the basis of a major comparative research project, 'Legacies of war and violence: Reconstruction and reconciliation in war-torn societies', of which this study is a part.

7 See 'The Legacies of War and Violence: Reconstruction and Reconciliation in Wartorn Societies' (Eastmond and Hettne 2002).

8 The UNDP has a more 'hands-on' approach through its focus on the following: sustainable recovery of communities, including increasing economic activity, security of livelihoods, income generation and poverty alleviation; reduction of the vulnerability of communities and individuals to future events; reintegration of returning refugees and IDPs; disarmament, demobilization and reintegration of excombatants; and increased capacity of peacetime governance structures and systems that provide essential services and of civil society at local and national levels (UNDP web site, 2003-01-22, http://www.undp.org/erd/recovery/index.htm).

9 The most extreme example of this is perhaps the UNDP's (2002) publication 'Lessons Learned in Crises and Post-Conflict Situations', though it only discusses the nature of the UNDP projects and their output and not whether these have generally contributed 
to the reconstruction and reconciliation of societies or the means by which these processes may have been achieved.

10 For instance, in Cambodia today, competent and non-corrupt political institutions are in short supply and this may be considered a major impediment to reconstruction. However, one reason for the ascendance of the Khmer Rouge was the utter failure of its predecessor, the Lon Nol regime 1970-75, to establish and maintain such institutions, so the argument that trustworthy institutions have never existed in Cambodia is persuasive ( $c f$. Chandler 1998). Thus, the challenge is not to rebuild what previously existed but to construct something new and more solid. It is also often argued that the period of conflict has created social fragmentation, which needs to be addressed. While this would be desirable, there existed no spontaneous 'sense of community' in the pre-conflict period either (Ovesen et al. 1996; Vickery 1986; Thion 1993). Again, 'new' rather than 'previously existing' structures need to be built.

11 This is neither an argument against the normatively desirable values of for example human rights and democracy, nor one that democracy is impossible to implement in certain cultures. It does, however, note that there are more and less efficient ways of promoting sustainable reconstruction and that it is often done without much reflection and knowledge, resulting in a sub-optimal process.

12 It is remarkable how difficult it is for the international community to work with bridging peace efforts and developments efforts. UNTAC had effectively no development component, and the development community has with one or two exceptions not worked with conflict resolution and targeted peace-building.

13 Mobutu in Zaire announced overnight 500 new parties, thus ridiculing demands for multi-party elections. The rapid inclusion of Spain, Portugal and Greece into the European community after the fall of the previous fascist regimes was to a large extent justified as attempts to consolidate fragile democracies.

14 This concept was invented in order to highlight the difference between the period of nation-state building and the subsequent, current period, during which 'globalization' became the primary rationale of the global system. This implies inter alia that 'tapping into global flows' and 'adapting' to the Global Political Economy is vital for development efforts ( $c f$. Hettne 2003).

15 We only need to recall Iraq and Afghanistan to realise the severity of external legitimacy deficits. In a more subtle form, the cases of Indonesia under Soeharto and contemporary Sudan are other cases in point. Cambodia (i.e. the regime at the time) was itself 'forced' into the entire UNTAC intervention/democratization since it was unable to survive without external recognition/legitimacy.

16 The turbulent 20th century in East Asia has provided several examples, such as Soeharto of Indonesia and Marcos of the Philippines. Both of these leaders tried but failed to mediate between incompatible internal and external demands, and eventually they fell. In the 1960s Cambodia's Sihanouk tried to gain both external and internal legitimacy. However, his political programme was ultimately unable to manage both aspects in the Southeast Asian political climate of the 1960s. In early 20th century China Sun Yat Sen over-emphasized foreign values, whereas Ho Chi Minh in Vietnam may have been one of those who best managed to combine the two. See Loh and Öjendal (2005) for a contemporary review of this issue in Southeast Asia. 
17 This refers to the period of Sihanouk's rule from 1953 to 1970, which is generally upheld as Cambodia's 'golden years'. It has been suggested that the prosperity and happiness of the period may be exaggerated in popular memory in light of what subsequently occurred.

18 In December 2007, during the final editing of this volume, the so-called 'Organic Law' was drafted. It included a thorough revision of the state administration ostensibly to further propel it in the direction of democracy. This reform would appear to remove the remaining non-democratic features of the institutional set-ups in Cambodia. However, as in many other realms, the outcome of this may not necessarily be 'democratic'.

\section{REFERENCES}

Alagappa, Muthia (ed.) (1995) Political Legitimacy in Southeast Asia: The Quest for Moral Authority. Stanford: Stanford University Press.

Ashley, David (ed.) (1998) 'The Failure of Conflict Resolution in Cambodia: Causes and Lessons'. In Brown and Timberman op. cit.

Barnes, Samuel, H. (2001) 'The Contribution of Democracy to Rebuilding Postconflict Societies. American Journal of International Law, Vol. 95, pp. 86-101.

Bastian, S. and R. Luckham (2003) Can Democracy Be Designed? The Politics of Institutional Choice in Conflict-Torn Societies. London: Zed Press.

Bermeo, Nancy (2003) 'What the Democratization Literature Says or Doesn't Say About Postwar Democratization'. Global Governance 9 (2): 159-177.

Brinkerhoff, Derick W. (2005) 'Rebuilding Governance in Failed States and Post-Conflict Societites: Core Concepts and Cross-Cutting Themes'. Public Administration and Development, Vol. 25, pp. 3-14.

Brown, Frederick Z. and David G. Timberman (eds) (1998) Cambodia and the International Community. Singapore: ISEAS.

Call, Charles T. and Susan F. Cook (2003) 'On Democratization and Peacebuilding'. Global Governance, Vol. 9, 2003.

Carothers, Thomas (2002) 'The End of the Transition Paradigm'. Journal of Democracy, Vol. 13, January 2002, pp. 5-21.

Cerny, Philip G. (1999) ‘Globalization, Governance and Complexity'. In Aseem Prakash and Jeffrey A. Hart (eds) Globalization and Governance. New York and London: Routledge, pp. 188-212.

Chandler, David (1983) A Cambodian History. Boulder, Colorado: Westview Press.

-_ (1991) The Tragedy of Cambodian History: Politics, War and Revolution since 1945. New Haven and London: Yale University Press.

- - (1998) 'The Burden of Cambodia's Past'. In Brown and Timberman op. cit.

-_ (2000) Bosnia: Faking Democracy after Dayton. London: Pluto Press.

Colletta, Nat and Michelle Cullen (eds) (2000) Violent Conflict and the Transformation of Social Capital - Lessons from Cambodia, Rwanda, Guatemala and Somalia. Washington: World Bank. 
Cousens, Elisabeth M. and Chetan Kumar (2001) Peacebuilding as Politics - Cultivating Peace in Fragile Societies. Boulders Colorado: Rienner.

Craig, David and Porter Douglas (2006) Development Beyond Neoliberalism? Governance, Poverty Reduction and Political Economy. London: Routledge.

Diamond, Larry (1999) Developing Democracy: Towards Consolidating. London: Johns Hopkins University Press.

Diamond, Larry and Marc F. Plattner (eds) (1993) The Global Resurgence of Democracy. Baltimore: The Johns Hopkins University Press.

- - (1998) Democracy in East Asia. London: Johns Hopkins University Press.

Doyle, Michael W. (1995) UN Peacekeeping in Cambodia: UNTAC's Civil Mandate. Boulder, Colorado: Rienner.

- - (2001) 'Peacebuilding in Cambodia: Legitimacy and Power'. In Cousens and Kumar, op. cit.

Eastmond, Marita and Björn Hettne (2002) The Legacies of War and Violence: Reconstruction and Reconciliation in War-torn Societies. Göteborg: Mimeo.

Finlay, Trevor (1995) Cambodia - The Legacy and Lessons of UNTAC. Stockholm: SIPRI.

Gallie, W. B. (1956) 'Essentially Contested Concepts'. Proceedings of the Aristotelian Society 56: 167-198.

Galtung, Johan (2001) After Violence: 3R, Reconstruction, Reconciliation, Resolution Coping with Visible and Invisible Effects of War and Peace. Accessed 15 September 2002. Available: http://www.transcend.org.

Green, Reginald Herbold and Ismail I. Ahmed (1999) 'Rehabilitation, Sustainable Peace and Development: Towards Reconceptualisation'. Third World Quarterly, Vol. 20, No. 1, pp. 189-206.

Hadenius, Axel (ed.) (1997) Democracy's Victory and Crisis. Cambridge: Cambridge University Press.

Hamre, John J. and Gordon R. Sullivan (2002) 'Towards Postconflict Reconstruction'. Washington Quarterly, 25.4 (2002), pp. 85-96.

Heder, Steve (2005) 'Hun Sen's Consolidation: Death or Beginning of Reform?' Southeast Asian Affairs. Singapore: ISEAS.

Hettne, Björn (2003) Från Pax Romana till Pax Americana. Stockholm: Santérus.

Hughes, Caroline (2003) The Political Economy of Cambodia's Transition, 1992-2001. London: Routledge.

Hughes, Caroline and Kim Sedara (2004) The Evolution of Democratic Process and Conflict Management in Cambodia: A Comparative Study of Three Cambodian Elections. Working Paper 30. Phnom Penh: CDRI.

Huntington, Samuel (1991) The Third Wave. Oklahoma: University of Oklahoma Press.

Jackson, Michael D. (2005) 'Chiefs, Money and Politicians: Rebuilding Local Government in Postwar Sierra Leone’. Public Administration and Development, Vol. 25, pp. 49-58. 
Junne, Gerd and Willemijn Verkoren (2005) 'The Challenges of Post-conflict Development'. In Junne, Gerd, and Willemijn Verkoren, Post-conflict Development: Meeting New Challenges. Boulder, Colorado: Rienner.

Kiernan, Ben (ed.) (1993) Genocide and Democracy in Cambodia. New Haven:Yale University Press.

Lawson, Stephanie (1993) 'Conceptual Issues in the Comparative Study of Regime Change and Democratization'. In Geoffrey Pridham (ed.), Transitions to Democracy. Aldershot: Dartmouth.

Lipset, Seymour Martin (1959) 'Some Social Requisites of Democracy: Economic Development and Political Legitimacy'. American Political Science Review, No. 53, pp. 69-105.

Loh, Francis and Joakim Öjendal (eds) (2005) Deepening Democracy and Restructuring Governance: Responses to Globalization in Southeast Asia. Copenhagen: NIAS Press.

Long, W. J. and P. Brecke (2003) War and Reconciliation: Reason and Emotion in Conflict Resolution. Cambridge, Mass.: MIT Press.

Luckham, Robin; Anne Marie Goertz and Mary Kaldor (2003) 'Democratic Institutions and Democratic Politics'. In Robin Luckham and Sunil Bastian, Can Democracy Be Designed? The Politics of Institutional Choice in Conflict-Torn Societies. London: Zed Press.

Luco, Fabienne (2002) Between a Tiger and a Crocodile: Management of Local Conflicts in Cambodia. An Anthropological Approach to Traditional and New Practices. Phnom Penh: UNESCO.

Lyons, Terrence (2004) 'Transforming the Institutions of War: Post-conflict Elections and the Reconstruction of Failed States'. In Rothberg, R. I. (ed.), When States Fail: Causes and Consequences. Princeton: Princeton University Press.

Mabbett, Ian and David Chandler (1995) The Khmers. Oxford: Blackwell.

Mansfield, Edward D. and Jack Snyder (2005) Electing to Fight: Why Emerging Democracies Go to War. Cambridge, Mass.: MIT Press.

McCargo, Duncan (2005) 'Cambodia: Getting Away with Authoritarianism?' Journal of Democracy, Vol. 16, No. 4.

Metzl, Jamie Frederic, 1995, 'The Many Faces of UNTAC: A Review Article', in Contemporary Southeast Asia, Vol. 17, No 1, June 1995, pp. 85-96.

Migdal, Joel S. (2001) State in Society - Studying how States and Societies Transform and Constitute One Another. Cambridge: Cambridge University Press.

Newell, Peter (2001) Globalisation and the Future State, IDS Working Paper 141. Sussex.

O’Donnell, Guillermo and Philippe C. Schmitter (1986) Transitions from Authoritarian Rule: Tentative Conclusions about Uncertain Democracies. Baltimore: Johns Hopkins University Press.

Öjendal, Joakim (2002) 'Globalizing the Southeast Asian Developmental State? Reinventing Local Development', presented at the SSAAPS-conference, Göteborg Sept. 
- - (2003) Ten Years of Reconstruction and Reconciliation - What it May Mean in Cambodia, Working Paper No 7, Göteborg University: Padrigu.

Öjendal, Joakim and Hans Antlöv (1998) 'Asian Values and its Political Consequences - is Cambodia the First Domino?' Pacific Review, Vol. 11, No. 4.

Orr, Robert (2002) ‘Governing when Chaos Rules: Enhancing Governance and Participation’. Washington Quarterly, Vol. 25, No. 4, pp. 139-152.

Ottaway, Marina (2002)'Rebuilding State Institutions in Collapsed States'. Development and Change, Vol. 33, No. 5, pp. 1001-1023.

- - (2003) 'Promoting Democracy after Conflict: The Difficult Choices'. International Studies Perspectives, Vol. 4, pp. 314-322.

Ovesen, Jan (2004) 'Political Violence in Cambodia and the Khmer Rouge "Genocide"'. In Richards, Paul (ed.), No Peace, No War; An Anthropology of Contemporary Armed Conflicts. Athens, Ohio and Oxford: Ohio University Press and James Currey, pp. 2239.

Ovesen, Jan, Ing-Britt Trankell and Joakim Öjendal (1996) When Every Household is an Island. Uppsala University: Department of Cultural Anthropology.

Pak et al. (2007) Accountability and Neo-Patrimonialism in Cambodia: A Critical Literature Review, Working Paper 34. Phnom Penh: CDRI.

Paris, Roland (2004) At War's End - Building Peace after Civil Conflict. Cambridge: Cambridge University Press.

- - (2006) 'Bringing the Leviathan Back'. International Studies Review, Vol. 8, No. 3, September.

Richmond, Oliver (2005) The Transformation of Peace. London: Palgrave.

Rigby, Andrew (2001) Justice and Reconciliation After the Violence. London: Rienner.

Roberts, David W. (2001) Political Transition in Cambodia 1991-99 - Power Elitism and Democracy. Richmond: Curzon Press.

Robinson, Mark and Gordon White (eds) (1998) The Democratic Developmental State. Oxford: Oxford University Press.

Rondinelli, Dennis A. and John D. Montgomery (2005) 'Regime Change and Nation Building: Can Donors Restore Governance in Post-conflict States?' Public Administration and Development, Vol. 25, No. 1, pp. 15-23.

Rothstein, Robert, L. (1999) After the Peace - Resistance and Reconciliation. London: Rienner.

Schurman, Frans (2001) Globalization and Development Studies - Challenges for the 21st Century. London: Sage.

Shamsul, A. B. (2002) 'Globalization and Democratic Developments in Southeast Asia: Articulation and Social Response’. In Kinnvall, Catarina and Kristina Jönsson, (eds), Globalization and Democratization in Asia - The Construction of Identity. London: Routledge, pp. 193-209. 
Skocpol, Theda (ed.) (1984) Vision and Method in Historical Sociology. Cambridge: Cambridge University Press.

Snow, Donald M. (1996) Uncivil Wars: International Security and the New Internal Conflicts. London: Rienner.

Sörensen, Georg (1993) Democracy and Democratization. Boulder, Colorado: Westview Press.

SPM (2003) 'Levelling the Playing Field for Democratic Governance - Technical Review of the DESA Project Portfolio in Cambodia, The Sixth Report of the Sida Advisory Team (SAT) on Democratic Governance in Cambodia'. Phnom Penh: Mimeo.

Therborn, Göran (1977) 'The Rule of Capital and the Rise of Democracy'. New Left Review, No. 103, pp. 17-41.

Thion, Serge (1993) Watching Cambodia. Bangkok: White Lotus.

Un, Kheang (2004) 'Democratization Without Consolidation: The Case of Cambodia, 1993-2004', PhD dissertation, Northern Illinois University: Department of Political Science.

UN (1992) 'An Agenda for Peace: Preventive Diplomacy, Peacemaking and Peace-keeping.' Report of the Secretary-General pursuant to the statement adopted by Summit Meeting of the Security Council on 31 January 1992.

- - (1995) The UN and Cambodia 1991-1995. New York: UN.

- (2001) 'Security Council, Presidential Statement, 20 February, 2001, Para 5'. New York: UN.

UNDP (2002) Lessons Learned in Crises and Post-Conflict Situation - The Role of UNDP in Reintegration and Reconstruction programmes. New York: UNDP.

- - web site, Accessed 22 January 2003. Available: http://www.undp.org/erd/recovery/ index.htm.

UNDP and UNFPA (2000) The Role of UNDP in Crisis and Post-conflict Situations. New York: UN.

Van de Put, Willem (1997) An Assessment of Community in Cambodia. Phnom Penh: Mimeo.

Vickery, Michael (1984) Cambodia 1975-1982. Bangkok: Silkworm (reprint).

- - (1986) Kampuchea - Economics, Politics and Society. London: Pinter/Rienner.

Weber, Max (1964) The Theory of Social and Economic Organization. New York: The Free Press.

Weiss, Linda (2000) 'Developmental States in Transition: Adapting, Dismantling, Innovating, not “Normalizing”'. The Pacific Review, Vol. 13, No. 1, pp. 21-56.

World Bank (1998) Post-conflict Reconstruction: The Role of the World Bank. Washington: World Bank.

Zartman, William (1995) Collapsed States: The Disintegration and Restoration of Legitimate Authority. Boulder, Colorado: Rienner. 


\section{Chapter 2}

\section{Reconstructing Legitimate Political Authority through Elections?}

\section{Caroline Hughes}

As the introduction to this volume notes, elections - particularly 'free and fair' ones - have been elevated to an unprecedented status in international policy-making over the past fifteen years. In the post-Cold War world, the holding and winning of competitive elections has come to be viewed as the badge of internal democratic legitimacy, representing a prima facie case for external recognition also. In Cambodia, this formula has caused a certain amount of anxiety amongst international policy-makers and local democracy activists alike. Cambodian elections have been held regularly, and, although not without their problems, have been judged 'credible' by international and local observers. The consequence of this has been the award of recognition to the Cambodian government by the international community, and the reward of aid to the Cambodian state on the part of most international donors, the US being a notable exception.

However, as the premise of this volume indicates, there remains a significant degree of unease over the nature of state-society relations in Cambodia. Problems include patently un-liberal and undemocratic government attitudes, including tolerance of rampant corruption and intolerance of political dissent, top-down policy-making which marginalizes the poor, and concomitant, or perhaps consequent, failures to alleviate poverty. There is clear dissatisfaction amongst the Cambodian people with the performance of their government in some of these respects. ${ }^{1}$ The question is whether this dissatisfaction represents a failure of the post-war regime to establish processes and institutions for delivering legitimate government. If so, why has this failure occurred in a context where regular, 'credible' elections are held? 
This chapter aims to address these questions, by focusing on the political function of Cambodian elections, historically and recently. Doing so requires scrutinizing the concept of legitimacy itself. Amongst international policy-makers since the end of the Cold War, legitimacy has been equated with democratic legitimacy, interpreted as a purely procedural affair - if the procedures of electioneering are properly held then the legitimacy of the outcome should be unquestioned. Less attention has been paid to the content of electoral debates. Cambodian elites have a tendency, when addressing one another, the international community and their own people, to pick and mix from a wide range of legitimizing discourses, drawn from ideologically driven interpretations of history, popular (and populist) notions of a supposed Khmer ethnic tradition, ideas of charismatic authority, and locally inflected interpretations of global discourses about international law, environmentalism, and the nature of modernity. This is not problematic in itself. Every election campaign in every country in the world, including in the so-called 'advanced democracies', is characterized by the construction of similar collages of image and soundbite designed to induce patriotic sentiment, ethnic chauvinism, modernizing zeal, fervour for over-simplified ideology, stereotyping of insiders and outsiders, and to spark fear in the breasts of the voters. Whether or not they add up to democratic legitimacy, procedurally defined, is a question of whether these contending sources of legitimacy are used to mobilize support within the confines of the election process or whether they are used to trump it.

International support for the role of elections in democracy promotion over the past fifteen years has been predicated on the assumption that the procedural legitimacy conferred by smoothly functioning electoral processes will eventually marginalize, or at least confine, challenges based upon different moral claims to power. This question is different, however, from the question of whether, in the eyes of Cambodian voters themselves, the present interplay between democratic and other forms of legitimacy evident in Cambodian electoral politics since 1993 adds up to the conferral of 'a moral right to rule' upon the claimants that have regularly achieved power - namely, the Cambodian People's Party (CPP) and its prime ministerial candidate, Hun Sen. If it does, then the present state of affairs can be seen as at least stable and broadly culturally appropriate, as the CPP maintains, even if not precisely democratic. If it does not, then the present state of affairs must be seen as unstable and oppressive, as consistently alleged by the opposition. The aim of this chapter is to analyse these contending claims. 
In investigating these questions, it is important to note the diversity within the Cambodian electorate. This diversity is visible in the fairly stable pattern of voting that has emerged at national elections until 2008, in which three parties have dominated the scene but none has ever won an overall majority. The CPP's share of the vote has climbed slowly from 39.2 per cent in 1993 to 47.4 per cent in 2003; that of FUNCINPEC has declined rather more sharply from 46.5 per cent to 20.8 per cent over the same period; while the third party, the SRP, which competed for the first time in 1998, has seen its share rise from 14.4 per cent in that election to 21.9 per cent in 2003. The same pattern persisted through the 2008 election. The voting figures doubtless reflect, to an extent, the procedural irregularities - ranging from violence, intimidation and vote-buying to haphazard registration processes, lost ballots, and altered figures - that have affected all Cambodian elections since 1993 and which have been largely attributed to the CPP. Yet freedom to campaign has grown over successive elections since $1993,{ }^{2}$ and local and international election observers have consistently judged Cambodian elections flawed but 'credible' in reflecting the range of opinions among Cambodian voters. ${ }^{3}$ Both the results and the observers' assessments of the processes suggest that most Cambodian voters perceive themselves as able to exercise some degree of choice at the ballot box, and that some Cambodian voters have consistently voted for a party widely recognised as abusive and corrupt, while others have consistently voted for an opposition that decries that abuse and corruption as rendering the perpetrators unfit to compete for power.

The basic ingredients for procedural legitimacy - some freedom of choice at regular intervals, a variety of contenders able to mobilize a reasonable degree of support, and a system that delivers a plural outcome - exist. This chapter investigates whether these ingredients, in the Cambodian context, add up to legitimacy for the current Cambodian government. If they do, then is that legitimacy specifically democratic legitimacy? If the current government has legitimacy, how do voters understand its rather exploitative and often violent activities, and why do they confer a moral right to rule upon leaders who behave in this way? Why have international observers found difficulty in conceptualizing the links between the way that voters understand legitimacy, and the question of awarding external legitimacy? In answering these questions, this chapter will reflect upon the legitimizing discourses used by the most successful Cambodian contenders in elections, historically and since 1993; the relationship of these discourses to the 
procedures of democracy; and the perspectives of voters and international observers witnessing these competitive displays.

Evidence will be presented here to suggest that elections contribute to establishing legitimate political authority in a number of ways in Cambodia: that the main utility of elections for Cambodian politicians is that they give an opportunity for them to enact forms of political behaviour which allow them to call upon a number of different forms of legitimation at once. In investigating this claim, I will briefly compare the electoral strategies of three political parties which have dominated Cambodian electoral politics historically and currently - namely the Democrat Party, the Sangkum Reastr Niyum (People's Socialist Community), and the Cambodian People's Party (CPP).

\section{DEMOCRATIC LEGITIMACY IN CAMBODIAN ELECTIONS}

The Democrat Party was the first significant force in Cambodian electoral politics, winning Cambodia's first election in 1946 and controlling the National Assembly until this was dissolved by King Sihanouk in 1952. Thereafter it declined in the face of police repression and opposition from King Sihanouk and was disbanded in 1957. The Sangkum Reastr Niyum was launched by Sihanouk in 1955 and dominated Cambodian politics, swiftly marginalizing the Democrat Party and all other electoral contenders, until Sihanouk's overthrow in 1970.

The Cambodian People's Party (CPP) is the successor of the People's Revolutionary Party of Kampuchea, the party which led the one-party state of the 1980s. The party marks its founding date as 1951 - the year when the Indochinese Communist Party was disbanded and replaced in Cambodia by the Khmer People's Revolutionary Party (KPRP). This party's Pracheachon (People's) group contested elections throughout the 1950s and 1960s, while the KPRP, which later became the Communist Party of Kampuchea, pursued underground activities. In the UN-organized elections of 1993, the CPP was beaten into second place by the royalist Front Uni National pour un Cambodge Independent, Neutre, Pacifique et Cooperatif (National United Front for an Independent, Neutral, Peaceful and Cooperative Cambodia, better known as FUNCINPEC), but the CPP subsequently won the 1998, 2003 and 2008 national elections with successively higher margins.

Investigations of the electoral records of these three parties suggest that all, during periods when they were successful, have relied upon their 
organizational capacities to mobilize voters, rather than an appeal to the voter's conscience or interests, to get the vote. The Democrat Party was formed by a progressive group of young elite Cambodians, recently returned from studies in France (Osbourne 1973: 42). As their name suggests, this party strongly promoted a notion of political authority as appropriately democratically legitimized - their platform comprised demands for 'independence and democracy' and attacks on 'nepotism and corruption' (Chandler 1991: 36; 38), and their vision for a post-colonial state comprised 'the achievement of a European-type parliamentary system with a maximum of democratic rights' (Vickery 1982: 91). These tenets were ideologically attractive to young, educated, urban Khmers; however, electoral success was determined by the ability to win the votes of rural peasants.

The style of rural campaigning adopted by the Democrat Party suggests that their ideological commitment to democracy, the source of their appeal amongst urban intellectuals, was not supported by their organizational strategy for winning the rural vote within the villages. Rather than attempting to win the commitment of villagers to their ideals, and thus spread a notion of elections as contributing to the democratic legitimation of those in power, and to the empowerment of voters as awarding authority to their representatives, the Democrats exploited the traditional respect accorded to members of the religious establishment to attract votes. Thus David Chandler writes that the Democrats 'took care to nominate candidates who commanded widespread local support, often choosing former monks or achar, whereas its leaders were drawn from Cambodia's elite' (Chandler 1991: 31-2). In his History of Cambodia, Chandler (1993) states that the Democrat victory in the 1946 elections 'revealed the popularity of the Democrat Party among Cambodian authority figures who were in a position to deliver the vote. In this election as in others over the next twenty years or so, many peasants voted as they were told to vote by people they habitually obeyed' (Chandler 1993: 175).

Also important to the electoral success of the Democrats was their popularity within the lower ranks of the colonial civil service. Steve Heder reports that the party maintained provincial and district committees within the state apparatus which 'often dominated the local state administration which was used to mobilise support and block activities by rival parties' (Heder 1998: 11). While the Democrat Party's ideology was crucial in winning support within the civil service, their electoral success emerged from the fact that support within the state 'was crucial to its ability to 
get out and win the vote', by exploiting their official power and status, rather than by winning battles of ideas (ibid.). While ideas of democracy and political freedom were important in determining support among urban intellectuals, victory at the polls, Heder and Chandler maintain, was achieved through the exploitation of networks of local administrative control and through tapping into customary structures of authority, rather than through fostering democratic values of political pluralism within rural villages. The 1990 s admonition that rural voters should vote 'according to their conscience' was conspicuously absent.

This strategy left the Democrats defenceless when a more powerful wielder of traditional authority entered the scene. By 1955, the Democrats' popularity had turned to impotence, in the face of an increasingly politically active monarch, King Norodom Sihanouk, who used his appeal amongst the peasantry to undercut the electoral base of the Democrats, at the same time as the party started to lose the battle of ideas amongst the urban elite over the question of independence. This had become a burning question in the light of the ongoing struggle in Vietnam. In the Cambodian countryside, insurgent groups, both nationalist and communist, were demanding independence and challenging French control militarily. Attempts to raise the question politically through parliament led the government into direct conflict with the French colonial authorities. The King dismissed the government and assembly and assumed full emergency powers in June 1952 with the full support of the French.

The decline of the Democrat Party partly reflected the problems of attempting to run a democratic government under a colonial system. However, it also reflected the importance to the Democrat Party of customary, rather than specifically democratic, structures of authority, demonstrated by their inability to respond when Sihanouk moved to coopt these in the service of his own political movement, the Sangkum Reastr Niyum. The Sangkum espoused a conservative ideology in which political power was portrayed in terms of a constellation of resonant symbols drawn from Angkorean iconography, French colonial discourse, newly invented nationalist sentiment, and village tradition. 'Buddhist socialism', as this ideology was named, drew liberally from Buddhist teachings on the duties of kings and subjects; myths about the glorious Khmer past at Angkor, based on the colonial dreams of French archaeologists; a supposed cultural disposition towards unity and consensus; and Cold War scare stories about the red menace. 
Organizationally, the Sangkum was held together by the person of Sihanouk himself, and designed so as to maximize perceptions of Sihanouk as not merely a political leader, but as the lynchpin of spiritual and secular authority structures that were central to post-independence Cambodian understandings of the Khmer political 'tradition' handed down to them from their Angkorean ancestors. On a wave of post-independence popularity, the Sangkum quickly absorbed pre-existing parties, including significant numbers of former Democrats, leaving only a weakened Democrat Party and the left-wing Pracheachon Party to contest the September 1955 elections. In those elections, the Sangkum gained all the seats in the national assembly and more than 80 per cent of the vote, to the Democrats' 12 per cent and Pracheachon's 4 per cent. Having gained an early monopoly of political power on the back of independence, the Sangkum cemented its hold on Cambodian politics for the next fifteen years through a mixture of tactics. Sihanouk himself pursued an energetic modernization programme, travelling the countryside, building hospitals, schools, roads and universities, and dropping presents from his helicopter to the toiling peasants in the fields below. This populist modernization drive was combined with the use of the Sangkum as a vehicle through which patronage could be distributed in the form of administrative offices and candidacies, all of which were awarded personally by Sihanouk until 1966. Meanwhile, the Sangkum's ideology marginalized contending opinions as un-Khmer, a source of dangerous and culturally inauthentic disharmony, which played into the hands of foreign powers that were poised to invade and destroy the Khmer land. In the deteriorating security environment of Southeast Asia in the late 1950s and 1960s, these rhetorical tropes had much resonance, and were quickly combined with colonial discourse and post-colonial sentiment into a powerful tale of Cambodia's tragic descent into poverty and ingloriousness at the hands of outside powers, primarily the Vietnamese, Thais and French.

This strategy proved effective in winning support at the polls, particularly as polling procedures were designed in a manner that mirrored the Sangkum's portrayal of the political community and the dangerous character of political debate within it. For example, in 1959, in response to an alleged coup attempt against Sihanouk supported by Thailand, Sihanouk called, not an election, but a referendum, to demonstrate popular support for his rule. The choices offered to voters were couched in foreign policy terms, as a choice between Sihanouk's 'neutralism', long portrayed as 
the only means by which Cambodia's independence could be maintained; 'pro-SEATOism' as espoused by one of the alleged coup plotters, a former Democrat leader named Son Ngoc Thanh; and 'communism'. Voting was organized by giving voters the choice between a photograph of Sihanouk, a photograph of Son Ngoc Thanh, and a red card to represent communism. Unsurprisingly, most voters went for Sihanouk, as representing monarchy, Khmer-ness, and independence, and because, David Chandler comments, voting for the alternatives entailed discarding a photograph of Sihanouk in public, which itself was grounds for imprisonment (Chandler 1991: 117).

It is evident that the legitimacy emerging from such events can be described as democratic only in a limited sense. Indeed, throughout the 1960s, political dissent increased swiftly, particularly among educated Khmer in the cities, who were influenced by alternative ideologies from both the left and the right, dissatisfied with increasing corruption and economic mismanagement and concerned by the deteriorating security environment. Their dissent was dealt with through heavy-handed repression, censorship of the press, restriction of contacts with foreigners, harassment of intellectuals by the police and the army, and political assassinations. All elections after 1952 were characterized by the intimidation of opposition candidates and vote-buying. David Chandler comments that by the 1962 elections, opposition to Sihanouk was 'terrorised, inert or in prison' (Chandler 1991: 120). Increasingly in the 1960s intellectuals accused of dissidence fled to the maquis, where the Communist Party of Kampuchea had formed a clandestine movement. Ben Kiernan characterized the situation in 1967 as one of 'near complete estrangement of the urbanised elite in Phnom Penh and elsewhere, with radicals and educated youth opposing Sihanouk from the left' (Kiernan 1975).

In the rural areas, however, where state penetration was limited, land was reasonably plentiful and capitalist modernization of the economy, in the form of plantation agriculture for example, was rare, Sihanouk's popularity was unchallenged. While few base line studies are available of peasant attitudes during the years of Sihanouk's direct rule, the fact that the Sangkum continued to mobilize support at the polls suggests that the ideology of Buddhist Socialism concurred in important respects with the peasants' own view of the situation; or at least that no alternative equally convincing discourse was available within which any grievances could be articulated. John Girling argues that the politics of Sihanoukism was 'widely accepted for more than a decade since [it] provided emotional 
satisfaction' (Girling 1971: 3). Oral histories collected by Kate Frieson from rural Cambodians tend to support this view. Frieson views lack of state penetration into the countryside, economic 'egalitarianism' in rural society and passive rural 'subservience to the centuries old monarchy ... spiritually legitimised through the Buddhist religion' as the three major obstacles to Communist Party recruitment campaigns into the 1970s (Frieson 1994: $15)$.

A number of historians and contemporary anthropologists have described Cambodian villages in the 1950s and 1960s as 'autarkic' in the degree to which they managed their own affairs and were insulated from the world of national politics. May Ebihara, conducting fieldwork in a Cambodian village in 1959, found that officials were viewed as 'outsiders' and treated with suspicion, but were not regarded as constituting a pervasive threat. Ebihara reported that the regional delegate to the National Assembly for her fieldwork village was 'a vague and remote figure who is supported because he has Sihanouk's endorsement' (Ebihara 1968: 537). ${ }^{4}$ Indeed, beyond the immediate sphere of face to face contacts within the village, the only recognizable national political figure was Sihanouk himself. Ebihara commented in 1968 ,

Political conflicts and parties do exist in Cambodia, but they are usually almost exclusively a phenomenon of the urban elite and intelligentsia and Svay's inhabitants know nothing of them. So far as the villagers are concerned, there is only Norodom Sihanouk, the nation's leader and the monarchy with which he is identified.

Ebihara 1968: 543-544

The successes of the Democrat Party from 1946 to 1952 and the subsequent ascendance of the Sangkum, which retained its hold on the allegiances of the peasants, if not the urban educated class, into the 1970s, can be attributed to the ways in which these movements adapted their mode of organization and political strategies to fit the structure of Cambodian society and politics. For the Democrat Party, the promotion of democratic ideals among an urban educated class was translated into victory at the polls through the exploitation of networks within the state and the ability of these networks to organize and mobilize a rural population that was accustomed to developing political strategies and making political choices in a local rather than a national context. Ideological tenets regarding the nature of government representation were less important than maintaining 
cordial relations with local leaders and patrons, in a village setting where the functions of national government appeared distant and were in any case strictly limited by the colonial power.

The fact that Sihanouk was able to claim the mantle of independence hero, along with that of monarch, descendant of the kings of Angkor and spiritual lynchpin of Buddhist cosmologies of power, enabled him to win popular support, undercutting the Democrats in rural Cambodia, and initially in urban settings also. That rural support continued for so long was a function of the fact that Sihanouk was able to exploit the distance between people and state. Where government touched the people in a positive way - through the school-building programme for example - Sihanouk was there in person to take the credit. Where government touched the people in a way that provoked resentment - through the corruption of officialdom, for example - Sihanouk was not there; or if he was, he took the opportunity to lambaste the official in question publicly. The relative thin-ness of statesociety relations in the villages permitted this situation to last for fifteen years, despite a deteriorating economy, increasing corruption, widespread human rights abuses, concomitant disaffection on the part of the newly educated youth and the urban elite, a gathering storm in Vietnam, and the best efforts of the Communist Party. While Sihanouk's authority was clearly legitimate in the eyes of the rural population during these years, this was a legitimacy that was based upon an ability to manipulate, in very fundamental ways, perceptions of the nation as this appeared from the perspective of the village. The staging of the 1959 referendum exemplifies this. The referendum represented an opportunity for Sihanouk to reinforce his view of the future of the nation as poised precariously between the capitalist and communist worlds. Sihanouk's rhetoric concerning the importance of Cambodia's 'neutralism' in the Cold War was itself a reprise of the rhetoric of the French Protectorate regarding Khmer vulnerability in the face of predations from the Thai tiger and the Vietnamese crocodile in the nineteenth and twentieth centuries. The representation of Sihanouk himself, hero of independence and descendant of Angkor, as the 'middle path' between right and left, Thai and Vietnamese, was essentially a restatement of his own vision of himself as both the incarnation and saviour of the nation, conceived both in secular and spiritual terms. It is important to note, however, that elections during the Sihanouk years suffered from declining turn-out rates, nationally, but particularly in Phnom Penh, where 
absenteeism in the 1958 election amounted to 55 per cent of the population, and to 80 per cent by 1966 .

This experience reflects an important aspect of political legitimacy. The ability to present certain types of authority as legitimate depends fundamentally on the degree to which such authority looms large in the everyday experience and political imaginings of individuals. A crucial determinant of attitudes to authority is the perceived relationship between that authority and the political community regarded as immediate and salient. Mobilizing acquiescence to policies which are perceived as far away and of marginal import for that community is considerably less difficult than mobilizing active support for policies which have a profound impact on everyday life and personal aspiration. Neither the Democrats nor Sihanouk attempted to persuade villagers of the importance of their policies. Instead, they mobilized villagers through customary and colonial authority structures, thus reasserting the importance of these as gatekeepers between the familiar world of the village and the unfamiliar world of the modernizing state. While the Democrats developed a network of supporters in the state and religious hierarchy who could achieve this, Sihanouk adopted a strategy whereby his own person, at the head of both state and religious structures, was conceived as the unifying force. Sihanouk's ceaseless journeying across the country, his attention to modernizing projects in infrastructure, education and culture, and the extraordinary efforts he made to project his personal presence across the territory entailed a conception of the nation, as viewed from the village, that largely inhered in Sihanouk himself.

This was a strategy that could work as long as the central government did not attempt to implement ambitious policies at village level that might directly challenge local power structures and subsistence strategies. The groups of people most directly affected by his government - the officials constrained to negotiate their way through the patronage networks he instituted; the urban dwellers who suffered from their corruption; and the educated youth who sought jobs in the deteriorating off-farm economy over which he presided - showed their view of his policies by abstaining in elections that offered no meaningful choice, and by supporting the rightwing coup that overthrew him. In rural areas, also, where modernization of agriculture did tentatively begin, as in Battambang in the late 1960s, bringing the modernizing spirit of Buddhist socialism into direct conflict with traditional strategies for economic survival, dissent was significantly greater. 
Aside from the impact of particular policies implemented, the cities, and specifically Phnom Penh, were far more open to foreign ideas from the left and the right that challenged the parochial romanticism of Buddhist Socialism. From the perspective of the city, Cambodia was not merely a conglomeration of autarkic villages united by a common 'Khmerness' that centred on Buddhism and the King. Rather, it was viewed as an independent, modernizing state, with a national economy that could, if well managed, offer them personal opportunities, and which also had a potentially significant role to play in emerging regional and international geopolitical orders. In relation to this view of the political community, the conception of authority offered by Sihanouk and Buddhist Socialism - that of cosmological order, dictated by the weight of history and tradition, which denied both opportunities for debate and dissent and any potential for individuals other than the Prince to contribute to the national project - operated poorly as a legitimizing discourse, particularly in the context of the economic and political stresses and strains that emerged in the 1960s.

\section{COMMUNITY AND LEGITIMACY IN CAMBODIA DURING THE WAR}

While it strains the terms of political discourse to apply the term 'legitimacy' to any of Cambodia's governments from the early 1970s to the end of the 1980s, arguably the 'bitter decades' of upheaval and destruction significantly affected post-war conceptions of community. It has been argued above that conceptions of community are significant determinants of legitimacy. In other words, legitimate political authority is not either present or absent; it is something that is shaded according to individual perceptions of the importance, relevance and immediacy of the authority in question. The war in Cambodia had profound effects on conceptions of community in Cambodia. Although the political rhetoric of post-war Cambodia on all sides of the political divide is markedly and self-consciously reminiscent of the political rhetoric of Sihanoukism, nevertheless the Sihanoukist rhetoric of today operates against the backdrop of the war, and its impact on Cambodian communities.

The republican government formed after the overthrow of Sihanouk was greeted with euphoria initially by young urbanites, but quickly became bogged down in disastrous warfare. Unable to mobilize support amongst the rural population, many of whom heeded the exiled Sihanouk's call to arms and joined the Communist Party, the urban-based regime collapsed 
once abandoned by its American backers. The Communist Party entered Phnom Penh and established the regime of Democratic Kampuchea (DK) unopposed by any organized political force. They then evacuated the cities and performed appalling atrocities on urban dwellers who died or fled in large numbers. Despite a division of the population into 'old' people (peasants and longstanding party members) and 'new' people (urban dwellers), and the better treatment of 'old' people, DK was not successful in legitimizing itself among the rural population that had brought it to power, because of the violent intrusion into rural lives that the regime's radical ideology dictated. The formal abolition of religion and schools, the attempt to curtail family life, the insistence upon hours of political education, the collectivization of agriculture and the incredible violence with which these policies were enforced entailed that the regime represented a massive shock to a rural population that had previously exhibited little desire to be remade through struggle into a revolutionary force. Furthermore, the failure of the regime's agricultural policies led to starvation, even among 'old' people, whose rations were initially more plentiful.

The Democrat Party and the Sangkum had attempted little in the way of remaking the structures of village authority, preferring to harness it to the business of mobilizing voters. However, the upheaval of the war and the DK regime had profound effects. Although DK ideology was based upon a notion of the rural Khmer as noble and progressive, the DK in fact attempted to destroy traditional rural community structures. May Ebihara, in her account of the impact of the DK on a village in Kandal province, describes how villagers fled to Phnom Penh in the early 1970s, to seek refuge from bombing, and then were evacuated back to their village by the DK in 1975. They were subsequently moved to a different site a few kilometres away, although a few were sent to Pursat province. Families were broken up and lands were confiscated. At the same time the formal abolition of religion removed the wat as a source of authority in the village, while the old administrative units of the pre-war regime were replaced by new numbered zones (Ebihara 2002). Ledgerwood and Vijghen report that outsiders were often brought in to administer cooperatives, 'specifically to break local-level bonds of loyalty' while other 'hierarchies and networks of social obligations were deliberately targeted for destruction' (Ledgerwood and Vijghen 2002: 119). These hierarchies were not replaced by the institution of any alternative, more nationally based, territorial administration. DK rule was highly personalized, due to a lack of a centralized bureaucratic apparatus 
that could administer on a mass scale, and consequently uneven across the country. However, the thinking of the DK was specifically national, and local communities, even down to the family, were ripped apart in the interests of promoting a national renaissance (Marston 2002). Meanwhile, the movement of individuals across the country, either at the dictate of DK leaders, in flight from their repression, or to return home or search for family members after the fall of the regime, represented a mass migration unprecedented in Cambodian colonial or post-colonial history.

Some recent studies suggest that the outcome of the destruction of local structures and the failure to replace them with any concrete national organization created an atomized society, based upon kin networks, and notable for its lack of either organizational or moral bases for collective action. ${ }^{5}$ The accumulated experiences of Sihanoukist boosting of an invented tradition of Khmerness, co-opted by the DK, and DK destruction of both organized village life and an urban intellectual class resulted in an absence of imaginings of community in Cambodia beyond an elevated view of Khmer greatness and a paranoid suspicion of the corruption of this both at national and at local level. This was exacerbated by the difficulties of re-establishing central control following the Vietnamese invasion of 1979. The incoming People's Republic of Kampuchea (PRK) declared a rebirth of the Cambodian nation in 1979, re-establishing a limited Buddhist establishment, re-opening schools and markets, permitting normal family life, and adopting a significantly more relaxed policy than their predecessors on collective farming.

However, the potential for mobilizing legitimacy for centralized authority was limited. In the catastrophic situation of the late 1970s and early 1980s, the PRK faced immense difficulties creating a national administrative infrastructure that was capable of successfully overseeing such basic policies as the conscription of soldiers to fight a revitalized National Army of Democratic Kampuchea, operating on the Thai border with foreign support; the prevention of the flight of the population to refugee camps on the Thai border where they would at least be fed; or the purchasing of rice from farmers to feed the urban population. Although the new government moved swiftly to create a local authority structure that assumed far-reaching powers to police mobility, religious observance, resource allocations and political sympathies, it faced determined resistance to many centralized policy initiatives, and was forced to concede the power to negotiate accommodations to its own local representatives. 
Such legitimacy as the PRK managed to institute in the ten years until the reform era began in 1989 was achieved primarily through appeal to an intense sense of national threat via continual reminders to the population that the regime constituted the only bulwark against the 'return of the Khmer Rouge'. The open links of the PRK to Vietnam entailed difficulties in using the notion of 'Khmerness' to great effect in articulating the nature of the 'nation' thus reborn and protected.

From the Sangkum onwards, successive regimes' attempts to promote their own legitimacy were heavily based on claims to defend a national imagining of the community. However, weak national administrative structures precluded effective mobilization around these claims, and waves of repression by political leaders against their own officials weakened this structures still further. The national identity proclaimed by politicians was not given administrative shape; in the Sangkum, the only national structure was the King himself, while the DK's disruptions of local political structures did not replace these by any sense of overarching national political or bureaucratic vision that was evident at rural level. For these regimes, the only manifestation of an emerging sense of nationhood was the hazy vision of 'Khmerness' articulated by Sihanouk and successive regimes after him. The PRK - openly backed and supervised by Vietnamese soldiers and administrators - had considerable problems mobilizing this trope to any political effect, also. As a legitimizing trope, 'Khmerness' became more of a problem than an asset.

Equally, the breakdown of ties within villages, the loss of family members, inward and outward migration, militarization, and the experience of chaos and destruction, create a new situation in which reconstituted villages exist in a milieu more frightening than before. David Chandler has noted a longstanding distinction in Cambodian culture between phum and prey - village and forest - as representing familiarity and civilization, in the former case, and strangeness and barbarism, in the latter (Chandler 1982); but in post-war Cambodia familiarity was itself made strange by the disruption to village communities. Internal displacement, refugee repatriation, and immigration have filled villages with strangers; the policies of both the DK and the PRK implicated religious authorities in politicking; and increasing difficulties in accessing cultivable land resulted in disruption to traditional methods of subsistence farming. The idea of culturally authentic 'Khmerness' made possible the notion of a nation that 'ought' to be ideologically in harmony in itself. This prompted difficulties in 
the post-war conceptualization of the political community, because of the dissonance between this rhetoric and the actual experience of national and local division, upheaval and unfamiliarity from the 1960s onwards.

Successive regimes attempted to explain away this dissonance by attributing internal dissent to external agents provocateurs who were seen as continually 'burrowing in'. ${ }^{6}$ The nature of these external agents varied. Sihanouk denounced the red menace, Thai plotters, and the CIA. The leaders of the Khmer Republic launched pogroms against the Vietnamese tmil. The torture centres and mass graves of Democratic Kampuchea were filled with suspected agents of the Vietnamese, CIA, and KGB, while PRK vigilance focused on the 'genocidal Pol Pot clique', also known as the 'gang of butchers', and 'Beijing expansionists'. Continual focus on these external threats, as a byproduct of the attempt to explain away the ordinary internal conflicts engendered by post-colonial state building and capitalist penetration, in a regional context of desperate conflict, has heightened the sense of vulnerability, at the national level but also at the individual level. Continued hysterical reference to the activities of traitors and enemies, assertions that the Khmer culture and nation are 'dying', and belief that Vietnamese interlopers are pursuing miscegenation strategies designed to taint Khmer blood, accompanied with the experience of warfare, violence and upheaval that reached into every village and caused actual death on a massive scale, have arguably given the pre-war rhetoric a new meaning that could not have been envisaged in the relatively peaceful autarkic villages of colonial and Sihanoukist Cambodia.

The idea of ethnic death took on a distinctively international dimension in the 1980s, when the dislocation and chaos of the 1970s was succeeded by an increasingly rigid division of the population into two contending nations. As the border camp system was established, the various insurgent or resistance movements on the border consolidated into the Coalition Government of Democratic Kampuchea, while the People's Republic of Kampuchea cemented its control of the interior. International recognition of, and support for, these contending nations - from China, ASEAN and the West in the case of the CGDK, and from Vietnam and the Soviet Bloc in the case of the PRK - further problematized the issue, as did the diplomatic efforts of the contending parties to seek external recognition as the rightful 'government' of Cambodia. The sensitivity of this issue was such that in the Paris Peace Agreements of 1991, none of the parties was named as a 
'government', although all were granted the status of having recognized 'existing administrative structures'.

Clearly, in the case of the resistance, these structures were rudimentary and confined to refugee camps or small enclaves, while in the case of the PRK, by that time renamed the State of Cambodia (SoC), the existing administrative structure was in fact a fully functioning, albeit weak, national state. The existence of two contending communities, with associated administrations, vying to be recognized internationally as the real 'Cambodia' heightened long-standing concerns that Khmer culture, as well as territory, was under attack from enemies that wished to debase and corrupt it. These concerns were reflected and promoted in the portrayal, particularly, of conditions in Cambodia under PRK rule in leaflets circulated in refugee camps. While PRK propaganda gushed about the liberation and rebirth of the Khmer nation, shoulder to shoulder with the peoples of Indochina, rumours in border camps and the West told of forced Vietnamization, politicization of religion and loss of Khmer culture.

For individual Cambodians, the splitting of Cambodia into two contending nations, recognized internationally by contending power blocs, and divided locally by swathes of landmines, by distinct assertions of geopolitical allegiance and historical trajectory, and by mutual denunciation of each by the other as a fake and corrupted mirage of the true Khmer nation, made the ability to imagine a united national community with a common past and a common future extremely difficult. At the same time, the imperative and naturalness of Khmer unity was felt more powerfully than ever before, and the problem of explaining the evident disunity was ever more difficult. One answer to this problem emerged along the lines of Sihanoukist and DK tradition: to regard 'Khmerness' as essentially pure but as having succumbed, in many instances, to the fatal corruption of foreign intervention, and thus to attribute 'foreignness' (dubious ancestry, brainwashing by foreign powers, or the possession of ' $\mathrm{Khmer}$ bodies but Vietnamese hearts and minds') to all those Cambodians who lined up on the 'other side'.

The question of how the 'nation' was to be conceptualized, emerged from the war significantly problematized. Locally, within Cambodian villages; nationally, among the contending Cold War Cambodias; and internationally, rhetorical traditions had emerged that imagined Cambodia as a community under attack. However, the outlines and character of this community were unclear. Continued obsessive questioning, within Cambodian political 
discourse, of the ethnic origins of individuals, of the numbers of ethnic minorities within the population, and of the exact location of Cambodia's territorial borders reflected difficulties in creating any secure imagining of the Cambodian nation. This clearly has major implications for ideas of democratic legitimacy. For the will of the people to be sovereign, there needs to be first a clear idea of who 'the people' are; and a fairly confident belief in their common concern to promote the continued sovereignty and well-being of the nation as a whole. In Cambodia, these ideas and beliefs continue to be problematic, both at national and local level. A valid electoral procedure is inadequate to award legitimacy to a sovereign national government if, as is often the case in post-authoritarian elections, not only the officials who implemented it, but also the observers who watched it, the parties who took part in it, and a substantial but unknown number of the voters who cast their ballots are all seen as potential threats, not only to the nation's health but to its very existence.

\section{LEGITIMACY IN CAMBODIAN ELECTIONS SINCE 1993}

Competitive elections were reintroduced in Cambodia in the 1990s, as part of the Paris Peace Agreements of 1991. The first competitive national elections were organized by the United Nations Transitional Authority in Cambodia (UNTAC) in 1993, as part of its effort to implement a comprehensive political settlement to the conflict. The 1993 elections were held in the context of a broken ceasefire, declining security, and recalcitrance on the part of the major parties, particularly the Party of Democratic Kampuchea, which withdrew from the peace process, citing bias on the part of UNTAC, and called for a boycott of the election, and the Cambodian People's Party, which resisted UNTAC's efforts to oversee its 'existing administrative structure', the State of Cambodia, as a means of ensuring a level playing-field for political competition. Because of the problems surrounding the 1993 elections, and continued problems of political assassination, intimidation and claims of vote-buying and electionrigging in subsequent electoral processes, elections have generally been regarded as an internationally imposed phenomenon, held for the purposes of beckoning international legitimacy, but cynically undermined by parties that either failed to understand or positively resisted the idea of democratic legitimacy. 
However, the fact that elections have continued to be held in Cambodia suggests that the ruling party - the Cambodian People's Party (CPP), which has gone from strength to strength in terms of its grip on power since the shock of its election loss in 1993 - sees some benefit in holding them. In fact, the CPP appears in a significantly stronger position domestically now than it did in the 1980s. Its main military opponents have either been co-opted or destroyed, and the major opponents of the party have found themselves increasingly hamstrung in their attempts to organize opposition to continued CPP rule. In part, this certainly reflects the use the CPP has made of the international aid that flows as a direct result of the continued timely holding of elections. However, it also reflects the fact that the CPP has used elections to strengthen its domestic legitimacy as well.

Central to this have been the ways in which the CPP has been able to manipulate conceptions of political community in post-war Cambodia. It has played upon the central rhetorical concern of post-war Cambodia - the difficulty of establishing a coherent and concrete notion of the national political community, and the anxieties this provokes regarding the possibility of national death - both in its electoral rhetoric and in its observable activities surrounding elections. In so doing, the CPP has been able to advance its own legitimacy in three ways. First, it has been able to present itself as the only organized force within the country, capable of preventing disintegration into chaos. Second, it has been able to both maintain and demonstrate the weakness of its opponents in this regard. Third, it has been able to strengthen itself internally and organizationally through the practice of subjecting its cadre to the experience of competitive elections. As a result of these advances in legitimacy, the CPP has been able to cement ties between the centre of the party, and its local representatives in villages and communes across the country. Through these three linked strategies, it has used elections to promote the idea that, however ethnically and politically suspect the party's own origins might be, it represents the only viable incarnation of a national, functioning, Khmer political community.

The major rhetorical tropes of all Cambodia parties in elections since 1993 have focused on the question of national death. Briefly, the CPP's claim to the vote has been twofold: the ability to maintain security and the ability to provide a basic level of functioning state services. Neither of these claims is unequivocal; particularly since the collapse of the NADK in 1998. In the 2000s, the major threat to the security of the average civilian 
comes from within the CPP's orbit, rather than from outside it, while the level of functioning state services available is entirely dependent upon the ability to mobilize contacts or pay bribes. However, the CPP's account of its history portrays it as the party that stepped into the chaos of the DK revolution and attempted to pick up the pieces in 1979; that held the line against the 'return of the Khmer Rouge' throughout the 1980s; and that oversaw weapons destruction programmes and mobilized resources for school building, temple restoration, and communications infrastructure in the 1990s and 2000s. The CPP portrays itself as the party of state-building and modernization. In 2003, for example, CPP officials across the country emphasized a single simple message to voters: 'We are the party that gets things done; don't bite the hand that feeds you."

For the other major parties, exiled in the 1980s and consigned to a junior role in the administration in the 1990s and 2000s, similar concrete achievements are hard to come by. FUNCINPEC has attempted little in the way of adapting the inherited rhetoric of Sihanoukism to new realities. The party continues to campaign almost exclusively on the notion that Cambodian voters will always vote for the King, as the lynchpin of the nation. Declining votes suggest, however, that the significance of the King in the eyes of the voters is itself declining, a notion also supported by the notable lack of social or political turbulence surrounding Sihanouk's abdication in favour of his son Sihamoni in 2004. Whereas Sihanouk in the 1950 s and 60s supported the message of his cosmological significance to the Khmer nation, spiritually conceived, with an energetic modernization programme that brought tangible benefits to rural communities, in the 1990s it is the CPP that has taken on the latter role, emblazoning the CPP's emblem and Hun Sen's personal monogram on roads, schools, bridges and temples right across the country. FUNCINPEC's efforts to compete have been lacklustre and unconvincing.

Both FUNCINPEC and the Sam Rainsy Party continue to emphasise the CPP's 'Vietnamese' origins, complaining in every election since 1993 that the CPP, in collusion with Hanoi, has mobilized Vietnamese immigrants to pour in from the east, given them fake ID cards, and registered them as voters to deliver a CPP victory. While this rhetoric regularly causes a great deal of concern amongst Khmer voters, the ability of these parties to deal with 'Hanoi' is undemonstrated, since, in the experience of most voters, neither have demonstrated the ability even to maintain party offices in the villages or to construct an adequate road. 
Furthermore, elections themselves offer a new opportunity for the CPP to demonstrate the effectiveness of its organizational apparatus in the service of the nation. Since UNTAC, elections have become, in effect, the leitmotif of post-war Cambodian order. UNTAC itself led the way in this respect, presenting the 1993 elections as a symbol of the UN's own success in intervening in Cambodia to bring about political change. In part, this was a public relations gambit on the part of the UN. Having failed, by early 1993, to hold the ceasefire and keep all the parties on board, the May 1993 election offered the last chance for the UN to achieve part of its mandate and present the Cambodian operation as a success. The fact that, against the political and technical odds, the UN managed to pull off an astonishing organizational feat, in getting almost 90 per cent of voters to the polls, itself legitimized the UN's operation in Cambodia, which was notably unsuccessful in so many other respects.

The kudos that the UN attracted internationally through its success in holding elections has not gone unnoticed by the political parties. For the CPP, in particular, the holding of regular elections is regarded as a legitimizing device, not so much because of the popular mandate it bestows, but because doing so upholds the CPP's claims to be the only party that can govern the country adequately, and the only party equal to the task of bringing peace to Cambodia and restoring Cambodia to its rightful place as a sovereign state in the international community. The ability to hold an election that is accepted internationally validates the CPP's claims to be a civilizing and unifying force in Cambodian politics. As Hun Sen himself has claimed, the winning of such an election is merely 'the icing on the cake' (Hun 1998 [author's own translation]).

This view of elections is supported by evidence that, within the CPP, the overriding imperative is that elections should be 'orderly'. The emphasis on peace and public order is regularly cited by CPP officials as the most important criterion for election success, and indeed, elections since 1993 have steadily improved in this respect. For the CPP, the ability to mobilize voters to go to the polls has always been an important aspect of electoral strategy, which has underpinned the CPP's attitude towards election campaigning and election administration.

Regarding elections as legitimating not only in the potential for winning them but also in terms of success in organizing them both reflects and promotes the continued identification of party and state within Cambodia, and particularly within the CPP. Although CPP officials are well-drilled 
in the language of the democratic separation of party and state roles, and although this was backed up in the 2003 elections by directives from the National Election Committee (NEC) insisting that officials should not campaign during working hours, the overlap between administration and campaigning activities remains important. For example, some of the most persistent illegal activities in Cambodian elections include the collection of voters' voting cards by local officials; the noting down of voters' voting card numbers; the marching of voters to the polls in groups led by village chiefs; and the directing of important administrative information towards party members. These have been attacked by opposition parties as intimidatory and exclusionary activities, designed to make voters feel coerced into voting for the CPP.

However, for CPP local authorities, accustomed to giving close direction to their constituents in political and administrative matters, there appears to be a strong belief that such activities contribute to the 'success' of the election by improving voter turn-out rates, in line with Hun Sen's assertion that the most important thing is that the election itself should run smoothly. While there is perhaps a certain degree of disingenuousness in the latter remark, it is nevertheless arguable that in fact the two issues are inextricably linked: that the legitimacy of the CPP stems not so much from the number of votes awarded to it by the voters, but from its ability to demonstrate that it can organize and mobilize voters to participate in a nationally-administered political exercise. This in itself is seen as equating to a mandate to rule, and a justification for any heavy-handed tactics that might have been employed along the way, given the lack of other contenders who can claim the same administrative effectiveness.

In the 2003 election, one of the main complaints by the losing parties after the election was that their supporters received inadequate information, and consequently went to the wrong polling station, could not find their name on voters' lists at the polling stations, or could not find the polling station at all. This was a problem that clearly emerged from inequalities of access to information on the part of voters. COMFREL warned before the 2003 election that the NEC's announcement to voters that they should check their names on provisional voting lists posted at commune offices before the election was unclear and not widely publicized, and that most of the population were 'oblivious to the announcement'. For CPP supporters, the task of checking their registration was performed for them by party 
officials and/or village chiefs. For those identified as opposition supporters, similar services were apparently not provided. ${ }^{8}$

One NEC member, interviewed after the election, confirmed that the CPP's party structure had provided this kind of information to CPP members:

The CPP checked all the details of the voter's name, voting card number and polling station and they write it on a piece of paper and give it to each member. FUNCINPEC didn't do this. CPP gave this piece of paper to each of their members, so when they arrive at the polling station they can find their name on the list very fast.

NEC representative, 7 Oct 2003

By contrast, members of other parties faced difficulties in finding their names, in crowded polling stations, without assistance from party officials and local authorities who were banned from the area of the polling station in an attempt to reduce the potential for intimidation or coercion of voters, and who, where they defied this ban, were in any case disinclined to assist people who were not members of their parties. Another NEC member defended the actions of CPP officials in this matter, again implicitly raising the issue of whether organizational efficiency in this respect justified the CPP's victory in the election, even though this victory may in part have been a product of such organizational efficiency, rather than a result of the popularity of the party's political platform:

After the commune councilelections, there are three parties in the commune council. We believe that in the village, if you have all three parties in the commune council, why don't the other parties go and give information too? If it's just the CPP in the commune then that's one thing, but you can't say that only the CPP can give information. SRP and FUNCINPEC are members of the commune council too, so they have the right to disseminate also. They can disseminate through the party.

NEC representative, 5 Oct 2003

The notion that political success is appropriately a function of the party's ability, not merely to convince the voters of a set of ideas, but to mobilize them on election day, arguably reflects the long-standing conviction, evident in the policies of the Democrat Party and the Sangkum, that legitimacy flows from organizational capacity, rather than primarily from an appeal to the conscience of the voter. 
A further complaint heard in both 1998 and 2003 was that the electoral apparatus of the National, Provincial and Commune Election Committees was dominated by CPP members. One of the national election monitoring organizations, the Committee for Free Elections in Cambodia (COMFREL), conducted a survey of Provincial Election Committee members in eleven provinces in 2003 and concluded that 79 per cent were affiliated in some way to the CPP (COMFREL 2003). The CPP has defended itself from this claim by arguing that its members are the only people in Cambodia with administrative experience, and that therefore there is no choice but to appoint these people to the task of organizing the election. This is a claim with which many international observers have reluctantly concurred. It is important to note, however, that whereas election observers regard this as an unavoidable stain on the legitimacy of the election results, for the CPP it advances the legitimacy to be gained from electoral exercises. By stacking the election apparatus with their own supporters, and gaining acceptance internationally of the view that they are the only party capable of organizing the election, they gain support for their main claim to power - the fact that they are the only organization in Cambodia that can get things done.

It is evident that for Prime Minister Hun Sen, this claim to legitimacy is the most important, far outweighing any legitimacy that might be gained from efforts to persuade voters of the political salience of his programme. For this reason, Hun Sen refrained from campaigning during election campaigns in the 1998 and 2003 elections, commenting that it would not be fair for the organizer of the election to also campaign for votes. This reflects an attempt to distance himself from the other parties, and to avoid being seen as merely another contender; it also reflects an appreciation of the legitimacy that is awarded by being regarded as the one who can organize the country.

The great importance of this arises from the very issue that the CPP's opponents emphasize: the insubstantial and intangible nature of the Khmer nation. For the CPP's opponents, the Vietnamese origins of the CPP corrupts all CPP efforts to create a concrete territorial apparatus for mobilizing and administering Khmer society and offers an opportunity for Vietnam to continue to control Cambodia's destiny. However, many voters find the alternative that the CPP posits - an ungoverned, violent chaos - a more frightening alternative.

A further advantage of elections for the CPP is that they confine the opposition to a set of roles from which their ability to challenge this form 
of legitimacy is extremely difficult. During the 1980s, the legitimacy of the CPP's precursor, the PRK, suffered from its inability to exert this kind of power over the population. The population were, in effect, always offered a choice, albeit an extremely difficult one: they could remain within PRK territory or they could undertake the hazardous journey to the resistance 'zones'. While these zones were unattractive in many ways, their continued existence offered a constant reminder of the limits to PRK power.

The peace process of 1991-93 and the subsequent cooptation of the PDK (Party of Democratic Kampuchea) into the CPP between 1996 and 1998 removed these visible limits to CPP power. At the same time, the military battle in Phnom Penh in 1997, and the subsequent destruction of FUNCINPEC's underground military network and flight of FUNCINPEC and SRP politicians from Phnom Penh, left the CPP unchallenged militarily and organizationally within Cambodia. FUNCINPEC and the SRP returned to Cambodia in time for the elections in July 1998, but without having the opportunity to build structures across the country that could operate as a similar alternative to the CPP's organization and could appear to voters as an alternative structure with the potential to govern the country.

This remained true up to 2003. Although FUNCINPEC returned to the governing coalition after the 1998 elections, it did so as the clearly junior partner. Both FUNCINPEC and the SRP gained seats, and in some cases commune chief positions in the 2002 commune elections. However, the insertion of these individuals into a local authority structure that was still dominated by the CPP, through its village chiefs, its continued numerical dominance on commune councils, its hold on the district and provincial administrations, and its entrenched position within line ministries and the armed forces, did little to change the view that FUNCINPEC and SRP representatives took part in government essentially on the sufferance of the CPP. The dynamics of commune government is still in a state of flux and it is too early to say whether the opening of this layer of authority will have significant effects on this perception in the long run. At the time of the 2003 national election, however, FUNCINPEC and the SRP appeared to voters, and to their own activists in the communes, as marginal players in the administration of Cambodia.

Like the Sangkum in the 1960s, the CPP's considerable advantage is conferred by the dual strategies of exclusion and repression of opponents, which is then used to demonstrate the weakness of these opponents, 
from which it is concluded that such opponents would not be capable of controlling the country even if they had the chance. The possibilities for FUNCINPEC and the SRP to challenge this perception are limited. FUNCINPEC's strategy of repeatedly entering the government as a junior partner has proved unsuccessful, since the party's leaders have been incapable of actually governing from within the coalition, given their inability to exercise control over organs of state that are dominated by the CPP. The SRP strategy of remaining outside the government allows them to retain a moral stance of indignation at government mismanagement; yet it also precludes them from doing anything to show that they represent a viable alternative. This leads voters to wonder what a victory for the opposition would mean in terms of the government of the country.

This is a very rational and real concern, and is frequently articulated as a concern over the question of a 'transfer of power'. In a country where not only the policies of the government but also the nuts and bolts of its functioning are closely identified with the organization of the CPP, it is unclear whether a FUNCINPEC-SRP coalition would indeed be able to exercise any kind of meaningful government at all. This scenario briefly presented itself in 1993, when a group of CPP leaders declared their intention to withdraw the eastern provinces from Cambodia altogether, in response to FUNCINPEC's electoral victory. The UN and King Sihanouk were widely seen as having capitulated to this threat in permitting the CPP to join a coalition with FUNCINPEC, with a status more elevated than, perhaps, its vote share would imply.

The situation in the $2000 \mathrm{~s}$ is different. Given the disarming of FUNCINPEC and the integration of the PDK into the CPP, an electoral victory for the CPP's opponents is perhaps unlikely to cause civil war. It is more likely, perhaps, that the CPP would itself split, and the engineering of such a split is something to which other parties have devoted a great deal of attention. The attitude of the military in such a situation is an important question. It is likely that different military commanders would respond differently, lining up on different sides of a political conflict, in response to their immediate economic and entrepreneurial interests. However, without the CPP to act as a stabilizing mechanism for controlling the military, albeit through the patently anti-democratic methods of offering patronage in the form of pay-offs and politicized appointments, widespread instability would be a likely outcome, thus buttressing the CPP's claims to be the only organization capable of governing the country. 
A significant absence in contemporary Cambodian electioneering has been any clear opposition stance on this question. Although the opposition has been active in attempting to develop a network of contacts among key power-brokers, viewed as potential allies, inside the CPP and the military, this activity has been conducted in secret. Consequently, the parties have been unable to articulate a strategy to the voting public. This permits the $\mathrm{CPP}$ to argue, convincingly, that the opposition response to such an electoral upset would be immediate flight. In view of the flight of the leadership of FUNCINPEC and the SRP in July 1997, and in view of a long history in postindependence Cambodia of the flight of dissidence in the face of repression, this argument is a credible one; indeed, the author witnessed FUNCINPEC politicians arranging visas for themselves and their families in case they needed to depart following the elections in 1998. While the plan may be to regroup in Bangkok to avoid immediate repression, and to mobilize international support for a triumphant return, this is not a scenario that is particularly reassuring to opposition supporters in the villages who would doubtless be left behind to face the music.

Indeed, for voters, the most immediate concern is the local level of government. Perceptions of the national level come via the local level, primarily via village and commune chiefs. At the village level, the CPP is still clearly in control, as the landslide victory for the CPP in the 2002 commune elections showed. In the surrounding forests, armed groups more or less loosely affiliated to the military prey on village orchards and forest resources and offer a disturbing and ever-present reminder of the chaos that could envelop the community, should the power of the CPP, seen both as organizing the civilian sphere and holding the military in check, be curtailed. The fundamental question, perhaps, at local level, is who has the power to protect, reward and govern? The answer, unequivocally, is, only the CPP - the party that has, as Hun Sen continually reminds voters, remained with them through the years of warfare, delivered them from genocide, rebuilt their schools and temples, and showed its ability, in the worst of times, to get things done.

The extent to which this message is perceived as reassuring depends in large part on the position of the individual within the village. In 1998, large post-election demonstrations took place, in which villagers from across the country fled their villages to Phnom Penh, in part to escape intimidation by CPP officials at home, and in part to register their anger at the prospect of continued CPP government. Interviews conducted at the 
time with some of these demonstrators indicated that their main grievance was their exclusion from the benefits awarded by the party at local level. Demonstrators complained that they had been identified as opposition supporters and that, consequently, they were excluded from the benefits of development assistance, prevented from getting jobs, and that they faced immense difficulties feeding and educating their children as a result (interviews with demonstrators, August 1998).

Such policies of exclusion continue within Cambodian villages and are crucial to the CPP's strategy of demonstrating the rewards that accrue to those who support the party that 'gets things done'. However, from 1998, the CPP has also been aware of the unpopularity of some of its own local officials, and has acted to discipline these. Indeed, one interpretation of the CPP's willingness to promote commune level elections, despite the risk that these would offer greater power at local level to the party's opponents, was that local elections offered an opportunity to jettison the most abusive and unpopular local chiefs that were denting the CPP's image in certain villages (interview with Ministry of Interior Official, June 1996). Indeed, the CPP, by virtue of its extensive organizational structure, has been the most sophisticated of the Cambodian parties in terms of tracking its own popularity within the country. For example, in 1998, the CPP held a secret ballot in preparation for the national elections of that year in the commune of Kraingyov, site of a development zone sponsored personally by Hun Sen, to gauge its popularity. Interestingly, the CPP is reported to have lost this ballot, a result that apparently led to a change in the Prime Minister's personal development strategies. Awareness that intensive efforts to provide an all-encompassing development strategy for individual communes was perhaps increasing resentments between local power-holders and those who were marginalized has led to a more arms-length approach in development assistance. Currently, pro-CPP newspapers, reporting on the resentments caused by the appropriation of gifts by local power-holders, take care to distinguish the 'corruption' of local officials on the ground from the highminded generosity of the absent benefactor. ${ }^{9}$

At the same time, national elections provide an important incentive to local level officials to comply with the party line. Compared to the 1980s, when the central state faced great difficulty in exercising control over local officials, particularly in relation to the implementation of socialist land distribution policies, the CPP now wields much greater control over its own cadre. Elections, arguably, and the central allocations of development 
assistance aimed at promoting electoral victory, have had an important role to play in this exertion of discipline. Periodic elections raise the spectre of loss of power for local officials, were the CPP to lose power and an opposition party to take over the government and enact root and branch reforms. This threat can be used to ensure that local officials, at least periodically, take a national perspective, and comply with demands for loyalty from the central party organization. As such, the enactment of the electoral contest imbues both the central party and the central state with a tangible purpose maintaining power in the face of a potential threat from opposition parties - in which the efforts of local cadres can be enlisted.

It is also likely that elections offer a significant boost to the authority of Hun Sen within the CPP. The ascent of Hun Sen within the party organization over the past fifteen years has been partly due to his astute use of patronage to gain control of the most important sections of the police and the army. However, there is also clearly a charismatic aspect to his authority, the significance of which is enhanced by the regular subjecting of the party to elections. At election times, the party requires an individual face which is not only recognizable, but also capable of inspiring both fear and confidence, depending upon where one stands politically. Hun Sen's description of himself as a 'strongman', his personal sponsorship of development projects, and the attention he pays to travelling around the country and meeting villagers in person, present him, like Sihanouk before him, as the apex of the pyramid of relations that constitute political authority in contemporary Cambodia. However, it is important to note also the difference between these two charismatic figures. Whereas Sihanouk traded on the cosmological significance of his royal blood, Hun Sen trades upon the power inherent in his personal patronage and control of a variety of social forces, primarily the military, the party, the state, and local authorities. Hun Sen's ability to fulfil this role has undoubtedly contributed to his personal consolidation of power, although there is evidence that this has been contested and resented within the upper echelons of the party. Increasing focus of the opposition upon the person of Hun Sen as the barrier to more cooperative relations, particularly during post-election horse-trading to form a coalition government, is a clear downside to the increasing equation of the party with the person of the Prime Minister, as the alleged split between Hun Sen and Chea Sim following the 2003 elections suggests. 


\section{LOCAL AND INTERNATIONAL RESPONSES}

To what extent do voters concur with the notions of political authority which underpin the legitimizing functions of elections described above? The evidence here is equivocal, but at least two points stand out. First, the image the CPP has projected is one of unassailable power and administrative effectiveness in promoting security and development, the alternative to which is chaos. This appears to closely accord with voter perceptions of the purpose of their vote: a survey by The Asia Foundation in 2003 found that 34 per cent of voters voted for parties who achieved 'development' and 30 per cent said they were voting for their party of choice because it had 'got things done'. A further 24 per cent reported that they would vote for their party of choice to keep the peace; 13 per cent said they would vote for the party their chief supported. Only 28 per cent of voters said they were swayed by a party's policies or ideology (The Asia Foundation 2003).

That voters are convinced by the CPP's message and use their vote strategically to defray the threat of chaos suggests that the CPP at least enjoys a certain degree of functional legitimacy in an environment where voters perceive few options for dealing with their major concerns of peace and development. The failure of the opposition parties to offer a realistic alternative has already been discussed. It is also the case that the issues of security and administrative capacity (how entrepreneurial interests within the military are to be controlled; how threats such as the secession threat of 1993 might be dealt with, other than by appeasement; how the country can be governed without the use of the politicized networks of loyalty and corruption that underpin the state at national and local levels) are never debated in election campaigning. While the Sam Rainsy Party, in particular, has taken pains to present the electorate with a picture of how CPP government works nationally and locally, and of the role of corruption within the CPP's intertwined state and party networks, it has not specifically addressed the question of how these networks are to be combated.

The CPP's pitch, then, is apparently convincing. But this is not the same as being popular. That the CPP is fully aware of this is evident from the degree of stage management that goes into CPP political activities. Interviews with members of communities patronized by Hun Sen suggest the degree to which Hun Sen's extensive programme of visits to his people are policed by local officials. Interviewees report that individuals viewed as 'rebellious' are made to sit at the back and warned to remain silent and that 
police attend meetings to keep an eye on potential trouble-makers. While Hun Sen's programme of personal donations self-consciously reprises Sihanouk's activities in the 1960s, he is reliant at least in part upon local officials to mobilize the applause..$^{10}$ The reports of demonstrators in 1998, who described policies to exclude them from benefiting from gifts donated by Hun Sen, because they supported the opposition, suggested that the penalties imposed on the 'rebellious' were serious and threatening. In the 2003 elections, the army and police were mobilized after polling day to occupy public spaces in Phnom Penh and to police the main highways into the city, to prevent the potential for any similar demonstrations breaking out. Politics in Cambodia, both at village level and at national level, continues to be associated with a powerful sense of threat, and the regular deployment of coercion, partly as an advertisement of the CPP's power to maintain order, as charged by the voters; but also purely and simply as a means to repress dissent.

International election observer exercises have encountered great difficulties in attempting to disentangle the obvious provision of a certain degree of choice from the pervasive sense of threat surrounding it, in their efforts to assess the legitimizing efficacy of Cambodian elections. In part this is because of the focus on the procedural aspects of electioneering. As indicated above, it is part of the CPP's bid for political supremacy to be able to organize smoothly run elections in which everyone votes and not many people are killed. Emphasis by international observers on the numbers of people voting, the secrecy of the ballot, the technical competence with which the ballots are counted, and the number of political assassinations consequently misses the point.

However, it is difficult to imagine an alternative mode for international election observation, because of the difference between external and internal legitimacy. Whereas internal legitimacy, as noted above, has a complicated texture, woven from a variety of different types of thread, which appear more or less prominent when perceived from different parts of the polity, the external legitimacy that permits a government to represent a state in the international system is cut from more standard cloth. Even in the current age of interdependence, intervention and invasion, to a great extent the principle of sovereignty entails that external legitimacy either exists or it doesn't. If it is there, then external agents must respect the principle that a state controls its own internal affairs. To the extent that the on-off switch 
of external recognition relies upon the complex play of light that comprises internal legitimacy, problems emerge.

Focus on procedural aspects of the election play to the on-off switch. Procedural democracy is transparent. It permits a focus on the quantitative rather than on the qualitative: asking how many people voted, rather than what influenced their voting choices; how many minutes politicians spoke for on television, rather than on what was said. It is difficult under any circumstances to define criteria for measuring the quality of democracy. Any criteria that might be offered would be difficult to observe, especially by foreigners election observers who do not speak the local language, do not know the local power brokers, and do not have the time to conduct extensive interviews with electoral participants. While international observers have focused on the question of whether voters were offered a choice, they have been unable to comment on whether the choice offered made sense in terms of voters' conceptions of political authority, understandings of power in their community, or beliefs as to what might be possible in the contemporary Cambodian environment. Where they have commented on these issues, their comments have been hotly contested both within Cambodia and outside it. In any case, producing such commentaries would greatly complicate external policy decisions which require a simple verdict as to whether the election was 'credible' or not. Given that domestic legitimacy is a question of shades of opinion that vary across the electorate according to the perspectives of individuals, the information available to them, and their perceptions of such issues as the nature of political authority and the contours of the political community, the ability to answer the question of legitimacy with a yes or a no necessarily entails simplification to the point of irrelevance.

It is significant, however, that Cambodian NGOs and opposition activists spend a great deal of energy liaising with international observers and attempting to influence their view of the situation. In the case of Cambodia's national election monitoring organizations, this is usually in an attempt to introduce greater sophistication and to assert Cambodian ownership of the question of the government's external legitimacy. For opposition activists, however, regular campaigns for the international community to withhold its recognition of a Hun Sen-led government serve a more complicated purpose. In part, they represent a simple challenge to any democratic legitimacy awarded by the election, either internally or externally, and an effort to remove the crutch of international aid that shores up the CPP's 
image of competence and control. Campaigning against recognition of the credibility of the election however also directly challenges the CPP's claims of administrative efficiency. For example, an SRP official interviewed in 2003 commented on the question of political violence:

The NEC, the Ministry of Interior and Hun Sen are yelling for people to be tolerant and peaceful, etc. But the question, with those appeals, is why are these things still happening? Is Hun Sen in control or not? If he can't control the country, he should step aside. He makes a lot of declarations, but if things don't happen then you start to question, who is running the country. And the fact is that no one is really taking the country, because no one takes responsibility for running the country. No one is prepared to take the blame.

SRP national representative, 3 July 2003

In this case, the opposition directly attacks the CPP's own claims with respect to the election: that its efficient implementation demonstrates the CPP's administrative capacities and thus legitimates its rule on functional grounds. Equally, campaigning for international support for the non-recognition of the elections also permits the opposition to present themselves as having sufficient power behind them to tackle the CPP's rather menacing hold on the country, and to effect a transfer of power. This was most evident in 1998, when, as post-election demonstrations gathered momentum and diplomatic efforts to resolve the post-election crisis were at their most intense, leaflets began circulating in Phnom Penh claiming that the US was poised to invade Cambodia and topple Hun Sen. These rumours gave an observable boost to demonstrations that were failing to attract a response from the CPP leadership. The SRP, in particular, continues to lobby vigorously internationally both over alleged crimes against humanity perpetrated by Hun Sen and over the question of democratic legitimacy in Cambodian elections. However, in contrast to the 1990s when diplomats in Cambodia placed the question of democracy high on the agenda, international views have swung towards Hun Sen's own perception of legitimate political authority based on the view that any state is better than a 'failed state'.

\section{CONCLUSIONS}

This exploration of political legitimacy in Cambodian national elections suggests a number of pertinent conclusions regarding the nature of 
elections in post-conflict societies. It has been argued that a major strand of legitimacy mobilized by the Cambodian People's Party in the 1990s flows from the party's ability to project, on the one hand, an image of unassailable power based upon organizational competence, and on the other hand, a threatening prospect of chaos and destruction should this organization be undermined by democratic processes. From one perspective, the claims of the CPP are invidious in that it is the CPP itself which is the organization most likely to cause such chaos. However, this perspective regards the CPP as a unified organization with unproblematic control over its component parts within the party, military and state. Given that in part the organizational coherence of the party since the departure of the Vietnamese in 1989 has depended upon its ability to deliver electoral victories that serve the interests of its powerful supporters, particularly in the military, it is not clear that the party would hold together in the event of an electoral defeat. It is also the case that while democratic reforms in Cambodia since 1991 have brought a plurality of parties into the political process, none of these parties, except the CPP, has offered the electorate a clear statement of how it would deal with powerful interests that at present are kept in check, to an extent, by the CPP's networks of corruption and protection. In effect, the choice facing voters at the polls is to continue to live with the exploitative and violent aspects of CPP rule in return for a continuation of the CPP's control of its component parts; or to reject the CPP and take the risk that the only alternative could turn out to be chaos. So far, a sufficient, and increasing, number of voters have opted into the CPP's network of protection.

This decision could be interpreted as capitulation to the threat of coercion, or a pragmatic appreciation of the realities of contemporary Cambodia, in which institutions have not emerged which can exercise power independently of the party. Again, this can be appropriately regarded as the outcome of CPP policies to maintain the party's own centrality to the functioning of the state. However, the process of separating party and state across the post-communist world has suggested that a sharp sundering of inextricably linked organizations has rarely worked well, and has frequently resulted in just the type of chaos that Cambodian voters fear. It is arguably the case that democratic institutions imported from Western models were not designed and are not equipped to deal with the kinds of powerful and violent interests that are left behind when conflict ends. 
Having said this, it is clear that an almost equal number of Cambodian voters are prepared to take this risk - specifically the almost 42 per cent that voted for FUNCINPEC and the SRP in 2003, as compared to the 47.4 per cent that voted for the CPP. There is clearly a split between a section of the community that regards the message of stability and administrative effectiveness offered by the CPP as the most cogent response to Cambodia's current situation, a declining number who see a return to monarchism as a viable alternative, and an increasing number attracted by the SRP's specifically liberal message of internationally-supported root and branch reform of the state. To some extent, Cambodian elections turn on contending conceptions of what political authority ought to be, and how it can be exercised in the present environment.

It is beyond the scope of this essay to examine in detail how such differences play out in terms of the demographics of the population, but it is possible to advance some very broad generalizations. CPP village chiefs interviewed in 2003 in three provinces regarded the young population as potentially the most likely to vote for the SRP. The young are clearly a group which benefit little from CPP policies, as the high rates of youth unemployment and landlessness suggest. They are also a group which are perhaps less motivated by fear of the chaos that their parents experienced in the 1970s and 1980s. The youthfulness of Cambodia's population means that this group will be increasingly important in determining the outcome of future elections, with perhaps profound effects on electioneering and election results.

There is also a clear split between the perspective of the urban and rural populations. While the urban population votes overwhelmingly for FUNCINPEC or the SRP, the rural population represents the power base of the CPP. This has been frequently explained by the fact that the rural population is more easily coerced by local authorities sympathetic to the CPP. However, research has also found that the rural population tends to have a more local perspective than the urban population. ${ }^{11}$ The view from the village and the view from the city are not the same. For villagers, the outside world flows in through the mediation of local authorities, and it is local authorities that have long provided protection from bandits, the military in the forest, and insurgent groups, while the CPP has been a primary provider of links to the outside world through its road and school building programmes. Consequently, the CPP is able to project its image of all-encompassing power more effectively in the village context. 
In the towns, by contrast, where opposition parties are far more active; where subsistence is affected by a much wider plurality of actors (private sector employers, landlords, customers, tenants, NGOs and foreigners); and where officialdom is more likely to present itself as an obstacle than an opportunity; the CPP has enjoyed limited success. To return to the significance of a central trope of political rhetoric, that of 'Khmerness' and its vulnerability, in the context of a city that has an increasingly global outlook 'Khmerness' is seen, perhaps, as better safeguarded by conformity to international norms of governance, as a safeguard against infiltration by 'foreigners' from a neighbour - Vietnam - that is viewed by virtue of its continued espousal of 'communism' as out of step with global society. In the village, by contrast, the imagining of the national community is to a great extent framed by the presence of the one concrete national structure - the $\mathrm{CPP}$. For villagers excluded from protection and patronage by the party, and threatened at election times, assertion of a different basis for inclusion - that of ethnicity, as championed by the opposition party - is often the only recourse. While these contending conceptions of the contours of the political community, the institutional framework that is capable of holding it together, and the resources of power available to support these, continue to circulate, it is difficult to foresee the triumph of procedural democratic legitimacy as the arbiter of Cambodian political authority.

\section{AUTHOR'S NOTE}

This study is based upon three sets of fieldwork. Research into the 1998 election was funded by the Leverhulme Trust; research into the election campaigns of the contending parties in the 2003 election was supported by the British Academy's Committee for South East Asian Studies; and fieldwork into the nature and functioning of conflict resolution mechanisms during and after the 2003 elections was supported by AusAid, under the auspices of the Cambodia Development Research Institute. The support of all these organisations is gratefully acknowledged.

\section{NOTES}

1 Corruption, particularly, registered high disapproval ratings in a 1998 survey on the subject; see Centre for Social Development, 'National Survey on Public Attitudes towards Corruption,' available online at http://www.bigpond.com.kh/users/csd/, 
accessed 27 September 2005. This survey, conducted in 1998, found that 98 per cent of respondents felt that ending corruption was important.

2 See Hughes and Kim (2004)

3 The national election observer organisations COMFREL and NICFEC pronounced elections 'credible' in both 1998 and 2003.

4 For descriptions of village 'autarky' see also Frieson 1994: 23; Vickery 1984: 13; Kiernan 1993: 13.

5 Notably, Ovesen et al. 1996.

6 For a discussion of this terminology, see A. Hinton (2002); for a discussion of its wider use in Cambodian political discourse, see Hughes (2004)

7 This message was conveyed by a number of interviewees, particularly village and commune chiefs and CPP provincial party officials interviewed in Takeo, Kompong Cham and Kampot provinces, during the 2003 elections.

8 For an account of this conflict, see Hughes and Kim (2004).

9 Such reports are discussed in greater detail in Hughes (2006).

10 It should be noted that a lack of freedom granted to independent researchers in Sihanouk's Cambodia entailed that the genuine nature of peasant approbation for Sihanouk was assumed rather than proven. However, Ebihara's 1959 account suggests that peasant support for Sihanouk was genuine in the village she studied (Ebihara 1959: 551-2).

11 See, for example Biddulph 2001, Hasselskog et al. 2000.

\section{REFERENCES}

Biddulph, Robin (2001) Civil Society and Local Governance: Learning from Seila Experience. Kuala Lumpor: UNOPS.

Centre for Social Development (1998) 'National Survey on Public Attitudes towards Corruption'. http://www.bigpond.com.kh/users/csd/, accessed 27 September 2005.

Chandler, David (1982) 'Songs at the Edge of the Forest: Perceptions of Order in Three Cambodian Texts.' In Alexander Woodside and David Wyatt (eds), Moral Order and the Question of Change. New Haven: Yale University Press, Southeast Asia Monographs 24, pp. 53-77.

-_ (1991) The Tragedy of Cambodian History: Politics, War and Revolution since 1945. New Haven and London: Yale University Press.

- - (1993) A History of Cambodia (second edition). Chiang Mai: Silkworm.

COMFREL (2003) 'Report on the Irregularities of Provincial Electoral Committee's Recruitment Procedures'. Press release, Phnom Penh, 23 May 2003.

Ebihara, May (1968) 'Svay, a Village in Cambodia'. PhD dissertation, Columbia University.

_- (2002) 'Memories of the Pol Pot Era in a Cambodian Village'. In Judy Ledgerwood (ed.), Cambodia Emerges from the Past, Eight Essays. DeKalb: Northern Illinois University Southeast Asia Publications, pp. 91-108. 
Frieson, Kate (1994) 'The Impact of Revolution on Cambodian Peasants: 1970-1975'. PhD dissertation, Monash University, 1992. Ann Arbor: UMI Dissertation Services.

Girling, John (1971) The Sihanouk Myths. Occasional paper no. 7. Singapore: Institute of South East Asian Studies.

Hasselskog, Malin, Krong Chanthou and Chim Charya (2000) Local Governance in Transition, Villagers' Perceptions and Seila's Impact. Phnom Penh: UNDP/CARERE.

Heder, Steve (1998) 'A Lesson in Power: the Rise and Fall of the Democrats'. Phnom Penh Post, 30 January-12 February, p. 11.

Hinton, Alexander (2002) 'Purity and Contamination in the Cambodian Genocide'. In Ledgerwood (ed.), Cambodia Emerges from the Past, Eight Essays. DeKalb: Northern Illinois University Southeast Asia Publications, pp. 60-90.

Hughes, Caroline (2004) 'Democracy, Culture and the Politics of Gatekeeping: The Transnation Goes Home'. In Brenda Yeoh and Katie Willis (eds), State/Nation/ Transnation: Transnational Communities in the Asia-Pacific. London: Routledge, pp. 197-217.

- - (2006) 'The Politics of Gifts: Generosity and Menace in Contemporary Cambodia'. Journal of South East Asian Affairs, Vol. 31, No. 3, pp. 469-489.

Hughes, Caroline and Kim Sedara (2004) The Evolution of Democratic Process and Conflict Management in Cambodia: A Comparative Study of Three Cambodian Elections. Phnom Penh: Working Paper 30, CDRI.

Hun Sen (1998) 'Twenty Minutes with VOA by Telephone'. Reasmei Kampuchea (Light of Cambodia), 14 August, pp. 1/11.

Kiernan, Ben (1975) The Samlaut Rebellion and its Aftermath: the Origins of Cambodia's Liberation Movement, Part I. Working Paper 4. Clayton: Centre of Southeast Asian Studies, Monash University.

Ledgerwood, Judy and John Vijghen (2002) 'Decision Making in Khmer Villages'. In Ledgerwood (ed.), Cambodia Emerges from the Past, Eight Essays. DeKalb: Northern Illinois University Southeast Asia Publications, pp. 109-150.

Marston, John (2002) 'Democratic Kampuchea and the Idea of Modernity'. In Judy Ledgerwood (ed.), Cambodia Emerges from the Past, Eight Essays. DeKalb: Northern Illinois University Southeast Asia Publications, pp. 38-59.

Osborne, Milton (1973) Politics and Power in Cambodia: The Sihanouk Years. Camberwell: Longman.

Ovesen, Jan, Ing-Britt Trankell and Joakim Öjendal (1996) Where Every Household is an Island: Social Organization and Power Structures in Rural Cambodia. Uppsala Research Reports in Cultural Anthropology 15. Uppsala: Uppsala University.

The Asia Foundation (2003) 'Democracy in Cambodia - 2003, A Survey of the Cambodian Electorate'. Draft Report, Phnom Penh, 16 May 2003, pp. 37, 44, 47, 48, 49.

Vickery, Michael (1982) 'Looking Back at Cambodia'. In Ben Kiernan and Chantou Boua (eds), Peasants and Politics in Kampuchea 1941-1981. London: Zed Press, pp. 89-113. 


\section{INTERVIEWS}

Interviews with demonstrators, 'Democracy Square' demonstrations, Phnom Penh, August 1998.

Interview with Ministry of Interior Official, Phnom Penh, June 1996

NEC representative, personal interview, Phnom Penh, 5 October 2003.

NEC representative, personal interview, Phnom Penh, 7 October 2003.

SRP national representative, personal interview, 3 July 2003. 


\title{
Chapter 3
}

\section{The Judicial System and Democratization in Post-Conflict Cambodia}

\author{
Kheang Un
}

After decades under foreign rule and tyrannical governments, Cambodia in 1993 through international intervention adopted a democratic system with a free market economy. Ever since, the country has struggled to deepen democracy and promote economic development. In any post-conflict society, progressive reconstruction requires a broadly legitimate political system, a system generally perceived as transparent, responsive and accountable. As Öjendal and Lilja, citing Brinkerhoff, state in the introductory chapter to this volume, 'Reconstructing legitimacy in the post-conflict states involves expanding political participation and inclusiveness, reducing inequality, combating corruption and introducing contestability.' Such processes require, among other factors, the existence of the rule of law sustained by an effective, independent judicial system. As the World Development Report 2006 emphasizes, 'The justice system can do much more to level the playing field in the political, economic and socio-cultural domains' (World Development Report 2006: 175). The presence of such a level playing field will help generate the trust of both the elites and the public in the political system, enabling the new regime's legitimacy to be enhanced, paving the way first for the emergence and then the maintenance of long term social and political stability.

Judicial independence was enshrined in the 1993 Cambodian Constitution to promote the rule of law and to protect political and civil liberties that in the past had been neglected and suppressed. Article 128 of the Constitution states: 'The judicial power shall be an independent power ... The judiciary shall cover all lawsuits including the administrative ones.' Article 130 affirms, 'The judicial power shall not be granted to 
the legislative or executive branches.' A written constitution, as in many emerging countries, is of course not a guarantee for judicial independence for it does not ensure the 'actual implementation and maintenance of an independent judiciary' (Howard 2001: 96). This chapter examines the Cambodian judicial system since the inception of electoral democracy in 1993, assessing its level of effectiveness and independence in upholding the rule of law and protecting civil and political liberties. To elaborate this assessment, the chapter is divided into three main sections. The first discusses the attributes of an independent judiciary and its role in deepening and sustaining democracy, contending that an independent judiciary can promote and maintain democracy by upholding the rule of law. The second section discusses the nature of the current judicial system. Beginning with the history of the judiciary, this section will then reflect on the issues of the judiciary's effectiveness and independence, arguing that the inability of the judiciary to maintain the rule of law is a consequence of scarcity in human and capital resources, low intra-institutional cooperation, corruption, political dependence and subordination, and widespread impunity. All of these problems are intertwined with patronage politics and the ruling elite's halfhearted commitment to democracy. The third section concentrates on how an ineffective, corrupt and politically dependent judiciary affects government legitimacy and hence democratic promotion.

\section{THE JUDICIARY AND DEMOCRACY}

Democratic promotion and sustainability requires the rule of law because it ensures political rights and civil liberties, and also serves as a 'mechanism of accountability' constraining the abuse of state agents, their associates, and institutions. Theoretically, the rule of law, according to Guillermo O'Donnell, means that 'Whatever law exists is written down and publicly promulgated by an authority before the events meant to be regulated by it, and is fairly applied by relevant state institutions including the judiciary.' Fair applicability requires that 'The administrative application or judicial adjudication of legal rules is consistent across equivalent cases' (O'Donnell 2004: 33).

Without the rule of law, there will be no checks and balances and hence no guarantee that the rich and powerful will act within legal and institutional boundaries. Under these circumstances, no horizontal or verticalaccountability systems can be maintained. Horizontalaccountability 
refers to the responsibility of one state institution to another, while vertical accountability means the responsibility of elected officials not only to voters but also to civil society organizations between election cycles (Diamond 2003). To maintain the rule of law, the judiciary requires independence or it 'can be easily manipulated to prevent it from questioning the illegal or arbitrary acts of state actors' (Larkins 1996: 606).

An independent judiciary theoretically should possess, among other characteristics, two fundamental attributes: party detachment and political insularity. Party detachment is the notion that conflicts should be adjudicated by judges who 'are independent from the parties in the litigation, not to be related to them or in any way under their control or influence' (Owen 1993: 55). In other words, judicial decisions should be contingent upon 'the objective principles of the law; not the social or political standing of the litigants' (Larkins 1996: 608).

Political insularity requires that the judiciary be independent of other political institutions (Fiss 1993: 56), implying that judges should not be employed as 'tools to further political aims or punished for preventing their realization' (Larkins 1996: 609). Political insularity is important because it enables the court to serve as 'a countervailing force within the larger governmental system' (Fiss 1993:56). This is what O’Donnell calls horizontal accountability and responsibility, wherein no public or private citizens - particularly the rich, the powerful or state institutions - can escape legal responsibility for their behaviour (O'Donnell 2004: 36-37). More specifically, the judiciary must possess the ability and the will to pursue the criminalization of political responsibility. Horizontal accountability can exist if judges feel comfortable and secure in their role as legal adjudicators who can confront other institutions. If judges fear being removed when they threaten the significant interests of certain parties, then they must appease powerful groups or individuals in order to stay on the bench. Consequently, judicial independence is undermined.

Furthermore, an independent judiciary is indispensable for promoting, sustaining and legitimizing democracy. This is particularly important in a post-conflict society such as Cambodia, where the regime's legitimacy requires not only periodical elections but the existence of an acceptable level of equity - expressed as equal opportunity through fair process. This is a process made possible by the pressure of an independent judiciary (World Development Report 2006). Ideally, an independent judiciary not only holds everyone equal before the law and protects political and civil rights, but also 
holds elected officials and their associates accountable for illegal actions (Huber et al. 1999: 197; Zakaria 2003). To be genuinely independent, the judiciary must be perceived by all members of the society 'as a legitimate institution for determination of right, wrong, legal and illegal' (Larkins 1996: 610). In this way, an independent judiciary can mediate conflicts among political actors in a legitimate fashion, a process that can minimize political violence and confrontation that could jeopardize political order and hence democratic advancement. ${ }^{1}$ Therefore, the closer a judiciary is to the ideal type, the better the rule of law is secured.

Democratic deepening requires the existence of pro-democratic political forces, including most significantly opposition political parties. The presence of vibrant opposition requires the existence of an independent judiciary. In other words, without independence, the judiciary could be a tool of the government to monitor and control political opponents and advance the interests of state agents and their associates (Heymann 1993). In this case, 'The judge's black robe', Irwin Stotzky writes, 'is another hated uniform of another establishment tool' (Stotzsky and Nino 1993: 23).

Judicial independence is also compromised by institutional weakness, which includes limited resources, low salaries, lack of trained personnel and low intra-institutional cooperation. Low salaries make judges and court officials susceptible to compromise and bribery. Lack of intrainstitutional cooperation is another weakness found in many newly emerging democracies, including Cambodia. Since no single agency can enforce horizontal accountability, the judiciary cannot perform its role effectively unless it receives support from other government institutions, particularly the police who investigate crimes and execute court orders and rulings. On this point Marvin E. Frankel writes: 'The principal lesson of a general nature is that judges cannot lead in the political process unless those with the troops are prepared, somehow or other, to move in the same direction' (Frankel 1993: 27).

The above theoretical sketch is of course an ideal type. However, the proximity of a country's judicial system to this ideal type is directly related to better protection of civil and political rights and results in a more equitable socio-economic and political field (World Development Report 2006). 


\section{THE NATURE OF THE CAMBODIAN JUDICIAL SYSTEM: A BRIEF HISTORY}

The discourse of judicial independence and effectiveness is new to Cambodia. A modern legal system was introduced by French colonial rule in the late nineteenth century and operated in Cambodia until 1975, when Cambodia fell under the radical regime of Democratic Kampuchea (DK). During this period, the majority of Cambodians had no contact with the judicial system, and those who were accused of crimes rarely found their basic rights fairly or effectively upheld (Amnesty International 2003).

The DK regime found no value or necessity in law, and terminated the legal system. The DK regime, the historian Michael Vickery writes, did not even have the 'pretense of legality' (Vickery 1986: 120). Almost all Cambodians with legal backgrounds were killed, while other legal resources such as schools, books, court buildings and legal texts were either destroyed or converted to other usages. Arrests, sentences and executions were made through arbitrary decisions of DK cadres who acted in the name of Angkar (the organization).

Thus, when the People's Republic of Kampuchea (PRK) came to power in 1979, there was no legal system in place. The PRK, following the Vietnamese and Soviet models, re-established a judicial system to give Cambodia at least the pretense of legality (Amnesty International 2003). Because of staff shortages, the PRK set up short-term training courses for would-be judges and prosecutors (Donovan 1993: 81-82). However, because the regime considered the legal system an integral part of the ruling party's apparatus, the training emphasized Marxist-Leninist doctrines over legal subjects (Gottesman 2003: 243). Prosecutors and judges were usually former school teachers and literate Cambodians with 'good biography', meaning that they had no political connection to the previous regime.

The PRK was slowly able to create a formal court system. However, as in other communist states, the PRK judicial system was subservient to the party and the government (Donovan 1993: 90; Gottesman 2003: 245-249). The official party line was that the court could not be entirely trusted, and this distrust opened a space for frequent interference in the judicial process by government officials at both the central and provincial level. ${ }^{2}$ The party or powerful individuals, but not law, determined the course of the proceedings and the verdicts of trials. A former Minister of Justice complained during a meeting at the council of Ministers in 1986: 'Sentencing depends on the 
influence of persons offering an opinion, not on the law' (Gottesman 2003: 254).

In 1989, soon after the departure of the Vietnamese troops, the PRK initiated a series of reforms, some of which were relatively cosmetic and others more substantial. The government took a new name, the State of Cambodia (SOC), and promulgated a new constitution that emphasized some fundamental freedoms and the rule of law. However, under the SOC government, the overlapping relationship between the judicial and executive branches remained (as in the colonial system) and the judicial branch continued to be subordinate to the party. A Supreme Court report to the National Assembly revealed this fundamental problem. The report states, '... the People's Supreme Court ... is not competent to resolve the suits itself, has only examined them ... so that they may be turned over to the competent organs to be dealt with. This is because we felt that the work of receiving and resolving suits is a matter of ideology' (cited in Fernando 1988:60).

After the 1993 democratic elections, Cambodia adopted a system of checks and balances in which judicial independence was enshrined in the constitution. Although the judicial system was thus secured in theory, it has never been able to uphold its constitutional mandate. Major problems embedded within the system that impede the judiciary's operations include but are not limited to a lack of material and human resources, a lack of independence, and corruption. The latter two issues, as we will see, are interconnected with the embeddedness of patron-clientelism, discussed below.

\section{LACK OF RESOURCES}

The judiciary faces a severe shortage of material resources. Budgetary allocations for the judicial system are channelled through the Ministry of Justice (MOJ), which had an annual budget of 0.1 per cent of GDP in 2003, and of which the courts received a small fraction. The budgetary allocation was significantly lower than those of defence and security, which received 1.7 and 0.9 per cent of GDP respectively (World Bank 2003:12). In actual monetary terms, the MOJ in 2003 received US 2.4 million dollars, while the Ministries of Defence and Interior obtained US 91.2 million dollars and US 65.5 million dollars respectively (ibid.: 13). According to the Phnom Penh Municipal Court, even that minimal amount arrived at the court late and 
irregularly (Phnom Penh Municipal Court 2000). ${ }^{3}$ Throughout the country court buildings are in deteriorating condition; office supplies within the court are totally inadequate (Council on Legal and Judicial Reform 2002a). Court staff are expected to provide their own supplies such as pens, paper, and legal forms. One court official sarcastically said: 'In Cambodia, the court is independent to the extent that the government wants it to be selfsufficient' (J 6, 16 August 2002). ${ }^{4}$ Consequently, these staff are expected by their superiors to ask for a 'contribution' - an informal fee - from litigants to cover these materials and to supplement their meagre income.

The Phnom Penh Municipal Court (PPMC) is the most important court of first instance in the country because it has jurisdiction over Phnom Penh city - the hub of wealth and power. However, the court house does not reflect its significance. The PPMC is a former villa that during the early 1980s was transformed into the municipal court. It is now in a run-down condition with garbage littered inside and outside the court compound. Water is found dripping over the staircases and inside some offices, and moss grows on the veranda of the court building. Trial rooms are furnished with a few simple pieces of furniture, and garbage litters the floor. The court house is extremely crowded; clerk desks are situated along the hallways, balconies and at the base of staircases. ${ }^{5}$

All modern equipmentand furniture, such as computers, air-conditioners, phones, chairs and sofas, found in the judicial chambers belong to individual judges and prosecutors. At this court there is no computerized system or even a file system for all cases. Cases are generally considered 'important and unimportant' depending on the amount of money clerks, judges and prosecutors can expect to extract from these cases and the social and the political status of litigants. Documents related to important cases are well taken care of, while those that are unimportant are not. On the morning of 23 September 2002 a young man was on trial on a charge of robbery allegedly committed in May 2001. At the end of barely twenty minutes of deliberation, before making his final judgment, the judge asked the accused to make his last appeal to the court. The young man said, 'I have been tried and convicted on this charge once already. I was sentenced to eight years in prison.' The clerk, the judge and the prosecutor looked awkwardly at each other and had no recollection as to whether the accused had been on trial before and had been convicted. ${ }^{6}$

In a 2002 annual report, Dith Munty, head of the Supreme Court and cochairman of the Council on Legal and Judicial Reform, depicted the general 
physical state of Cambodian court houses as follows. 'Working places are located in apartments or in people's residents [sic] built partly from bricks and partly from woods [and now] are in old almost collapsed, narrowed and crowded conditions which is not suitable as a valuable place for finding justice for the people' (Council on Legal and Judicial Reform 2002).

A PPMC court official said: 'If we talked about materials [and] building, it is zero. It is not suitable as a court. There is no janitor. Other government ministries have janitors. The dirty place is the court' (J 1, 9 October 2002). Another official commented: 'The government does not pay much attention to the judicial system. The Phnom Penh Municipal Court is a small cottage of justice; it is not a palace of justice [tolakar krong Phnom Penh keu chea kaun khtom yutethoar mimmen chea veang yutethoar te]. I would like the Phnom Penh court to become a palace of justice. But the request for money to construct a new building was denied' (J 3, 27 September 2002).

Court infrastructure has never been a priority on the agenda of the Cambodian government. Prime Minister Hun Sen, in a speech at the workshop on Cambodian judges and prosecutors, brushed aside Munty's comments, as follows:

I carefully read the report H.E. Dith Munty prepared for this workshop. Some courthouses are built from wood and brick that is not the proper place for giving justice to citizens. This problem will be solved step by step. Do not ask for 50,000 million riels in 2003 for this. If so, this means we spend our budget for building courthouses but not road building ... We need to have more money, we need to collect tax from farmers so that we can build courthouses ... Collecting taxes ... from farmers for only building courthouses is not possible.

Sen 2002

However, several court officials contend privately that constructing courthouses is not a matter of lack of budget but is rather a matter of government policy toward the judicial system. A court official states:

If the government wants to pay attention to the court, they could. The government can get a new building for the Phnom Penh court if it wanted ... Look, how big the building for the Department of Foreigners of the Ministry of Interior. They have power; they can ask for money to build the building. 
The Cambodian legal system also faces a severe shortage in human resources. By the end of 2002, the Kingdom had 198 judges (Sen 2002). Of this minimal number, only a handful have proper legal qualifications. The level of education among Cambodian judges is well captured in a newspaper title: 'Disorder in the Courts: From Highly Educated to Unschooled, Cambodian Judges are a Mixed Pot' (McEvans and Phann 2000).

According to a 2000 Asian Development Bank (ADB) study, out of a total of 171 judges, while 40 per cent of them had attended (but not necessarily finished) lower secondary or high school, an additional seven per cent had only primary education. The remaining judges had Buddhist education or had completed or nearly completed Bachelor's degrees in either law or other disciplines (Asian Development Bank 2000: 85). The level of education among prosecutors appears similarly grim. The same ADB report states that while only nine per cent hold a formal law degree, less than a quarter of the total 54 prosecutors have had any formal legal education (ibid.).

One judge commented that 'The court began from point zero in 1979. There were very few lawyers left. Judges have little education. Talking about the judicial system, they [foreigners, especially westerners] laughed at us. Our society is poor; in other countries, they wouldn't let me hold this position [the director of a provincial court]' (J 7, 10 March 2003). ${ }^{8}$ As a result, judges commonly find themselves incapable of resolving legal issues that arise. In reference to the increase of salary for judges, a clerk at a provincial court said: 'The government should not pay judges that much because they are incompetent. They do not know the law or legal procedures' (J 37, 28 December 2002). ${ }^{9}$

Cambodia also faces a lawyer shortage. While a total of 275 lawyers are certified to practise law, only about 180 are believed to engage in legal practice (Coren 2003). Cambodian lawyers also possess a wide variety of educational backgrounds. Some of them were certified to be lawyers after they gained experience serving in the legal system, particularly as a clerk. Consequently, a combination of limited legal experience and knowledge of the law and legal procedures among lawyers and corruption negatively affect the quality of legal representation. Based upon his personal observations of court hearings in Cambodia, a western embassy staff member, an attorney by training, noted that Cambodian lawyers are not competent and they did not present solid evidence. He added, 'No evidence presented by the lawyers would stand up in any other court' (D 1, 6 June 2003). ${ }^{10}$ 
This author's observations, after attending many court sessions over a period of several months, revealed that there was little cross-examination during the trials. Lawyers are either fearful or inexperienced in challenging prosecutors or judges during trials. Such fear derives from concerns - real or perceived - that judges would rule arbitrarily against their clients in the current trial or future trials. 'Lawyers, if they dare to argue a lot [in the court room]', a court clerk said, 'might lose even their underwear' (J 9, 4 December 2002). A lawyer claims that some lawyers lost their jobs because of judges' unfavorable rulings against their clients, not on legal grounds but out of personal revenge against the lawyers who had openly challenged judges during trials (J 34, 25 August 2002).

\section{Low Intra-institutional Cooperation}

The justice police are an auxiliary arm of the court, assisting on judicial issues including investigations and execution of court warrants and rulings. By law, the prosecutors have the responsibility to supervise the justice police in the latter's working relationship with the court (J 3, 27 September 2002). However, the court and the justice police are in constant confrontation with one another, a precedent that dates back to the 1980s. At that time top PRK leaders debated the relative role of the two institutions, and the outcome was a general tendency to protect law enforcement from rival 'branches of government' including the judiciary (Gottesman 2003: 252-253). This legacy continues into the present, whereby the police threaten, ignore, or at best offer lukewarm support to the court. The Prosecutor General in his 2002 annual report stated, 'Prosecutors have difficulty because of a lack of cooperation from local authorities', which includes the judicial police. Commenting on the report, a prosecutor from Sihanoukville stated, 'What the Prosecutor General has raised hits the main point, and that is that prosecutors throughout the country and the judicial police seem not to be on good terms. This is the truth' (Council on Legal and Judicial Reform 2002).

The subservience of the judiciary to the police power rests on multiple factors, some of which are endogenous while others are exogenous to the judiciary. Exogenous factors are administrative and political. The administrative problem derives from the chain of command of the justice police. Although under the law the justice police are under the control of prosecutors, their salary, promotion and demotion are under the control of the Ministry of Interior. Thus, a prosecutor explains, 'If the activities of 
prosecutors or judges affect the interests of their superiors, they [the justice police] would not participate in these activities' (J 3, 29 September 2002).

Politically, the state does not trust the judiciary and it employs the police as a check on the court. This author's research reveals that there is a general agreement among court officials - clerks, prosecutors and judges - that the court receives only lukewarm cooperation from the police. Consequently, there have been numerous instances and allegations in which the judicial police refused to execute court warrants or rulings. This is a major problem, said a prosecutor, adding that 'In some cases the higher authorities defended the police when the police did not execute court orders' (J 2, 14 May 2002). On 21 October 2002, the court issued a detention order for an alleged offender, Peng Leang, representative of Chilbo Industrial Co. Ltd., but the Justice Police of Phnom Penh Municipality refused to arrest him. The police, according to a PPMC judge, decided that the court warrant was 'unfair'. The judge added that 'Monitoring the improper conduct of the court is the duty of the Supreme Council of Magistracy. ${ }^{11}$ However, the police's defiance of the court received widespread approval from the executive branch, including Prime Minister Hun Sen. Responding to the report filed by the Ministry of Interior, Prime Minister Hun Sen affixed the comment, ' $[\mathrm{I}]$ would like to congratulate the intelligence of our police officers who did not execute the abusive charge of the court that would make investors afraid' (Ministry of Interior 2002).

The police assert that they refuse to execute court warrants or rulings because they are unjust. Some observers, in fact, view police noncollaborative behavior as resistance to yielding power to the judiciary. 'During the SOC regime', a judge stated, 'power was in the hands of the police. Now the court has some power. The Ministry of Interior is unhappy with us [the court]. They say the court is incompetent [and] corrupt. Thus, when the court issues warrants, local police do not execute [those warrants]' (J 10, 15 October 2002).

Other judges and prosecutors see the police as acting as a kind of appellate court that has the right to retry the rulings of the court of first instance through their refusal to execute court warrants and rulings. Clerks, judges and prosecutors are all dismayed by the police behaviour. The justice police act, a judge said, as if they are the 'second court', justifying his claim by stressing that the police 're-examine and re-evaluate our decisions. Thus, we have no value' (J 16, 28 October 2002). 


\section{Corruption and Patronage}

Court officials also suggest that impunity is a product of patronage, corruption and the abuse of power. Despite the existence of internationally endorsed 'free and fair' elections, the state is not being ruled by democratic political institutions. The mechanism through which the state is governed has changed little since the late 1980s. The Cambodian state is structured by interlocking pyramids of patron-client networks that serve as a means of exclusion and inclusion in a multi-network competition (Heder 1995). In other words, like many developing countries, the Cambodian state is built not on rational institutions but on patronage, a political pattern in which a leader's power comes from his ability to capture and maintain loyalty of key sections of political elite by fulfilling their material aspirations through the distribution of perquisites (King 2002: 609).

Like the court, the police are trapped within the system of patron-client politics. Facing pressure from high-ranking government officials, the police do not execute all court warrants or rulings. 'I believe there were powerful people', a judge said, 'who intervened with the police commission, then the police did not carry out court warrants' (J 19, 19 December 2002). The police generally do not execute court warrants or rulings if there are no monetary incentives. In some court cases, the plaintiffs have to pay the police to execute court warrants or rulings. 'Plaintiffs who have money can make the police work faster by offering them money. But if plaintiffs do not have money to give to the police, the police will not execute court warrants [or rulings]' (J 40, 27 September 2002).

Court officials including judges and prosecutors publicly stated that low salaries are a factor contributing to judicial corruption. Up until 2002, the average monthly salary for judges, prosecutors and other court officials was around US\$24. A monthly salary of US\$24 was never anywhere near sufficient to support individual court officials, let alone their families. According to a judge, the living conditions of court officials under the current regime are poorer than those during the PRK/SOC. During that period, the government at least offered state employees, including court officials, supplementary rations including rice, gasoline and soap (J 7, 3 October 2002). Therefore, poverty causes corruption. As one judge acknowledges, 'The court is corrupt and that I am not denying. But there are some good people. There are some bad people but these people are the product of poverty. Poverty generates illegal acts' (J 14, 21 October 2002). ${ }^{12}$ 
Corruption is not attributed as much to poverty as it is to rent seeking behaviour, a common practice of present day Cambodia. Through decades of war and social upheaval, Cambodians experienced constant uncertainties in their lives. Such uncertainties forced many of them to maximize their personal gains whenever opportunities permitted, with little concern for societal consequences. However, because of an absence of institutional constraints, rent seeking behaviour has become excessive, permeating all state institutions. The propensity of corruption is enforced by the belief that their posts are temporary, therefore prompting them to take advantage of their position whether through legal or illegal acts. 'Corruption among judges in the court does exist', says a prosecutor. 'Some judges think that they will not occupy their posts forever, so they engage in bribery. It is dreadful that way' (J 3, 17 October 2002).

The absence of institutional constraint coupled with a wider sociopolitical environment dominated by patronage and corruption blurs even judges' perceptions of what constitutes legality and illegality, and morality verses immorality. Judges whom the author interviewed did not reject the allegation that the courts were corrupt. However, they defended their actions forcefully arguing that some acts of receiving money from litigants do not constitute corruption. Rather, they argued that these monetary transactions can rightfully be called 'fees'. Accepting such a fee is not wrong - if not legally, at least morally. Defending their act of accepting money from litigants, a judge explained: 'We [judges] help those who are right. [When] they win their cases, they repay their gratitude to us [pel ke chneah ke song sarkun yoeng]. This is Khmer culture' (J 24, 18 October, 2002).

Another judge admitted that she accepted money from people. However, she emphasized that 'What should be asked is what service did I provide those people? The money that they offered was for the service that I offered them and this service is not at all illegal. If accepting money for doing things is illegal, then it can be called corruption. If accepting money for doing things is legal, then it cannot be called corruption' (J 10, 15 October 2002). Tith Sothy, chief judge at Kampong Cham provincial court, was reported to have admitted: 'I cannot tell a lie. Even I take money from time to time. But after the case is decided, and sometimes I do not know they are giving me money. Sometimes, they are giving me a box, and I think it is a gift' (cited in McEvens and Phann 2000).

Despite the judges' claim of moral conduct, this author's interviews and conversations with clerks, lawyers and litigants reveal that very often judges 
manipulated those who came into contact with the judiciary to ensure the maximum bribe. According to a lawyer, on some occasions judges employed delaying tactics in their rulings in order to extract more bribe money from litigants (J 34, 25 August 2002). The office of the former governor of Phnom Penh alleged that seven PPMC judges accepted US $\$ 310,000$ in bribery in exchange for releasing 20 criminals (Khon 2000: 44).

Corruption within the judicial system is intertwined with the overarching system of patronage; they are two aspects of a single way of thinking of power. As in other branches of the government, merit counts for little within the judiciary. On the contrary, appointments and promotions are based on patronage and bribery. 'Within the court system', a prosecutor said, 'if someone wants to be promoted he/she has to make a request and the request involves paying a bribe. I could not understand. I knew some people who requested to be promoted and they did just that [paid a bribe]' (J 3, 2 October 2002). Transferring to PPMC or to the court in a prosperous province also requires paying a bribe. A judge who was able to get transferred from a remote province to a more populous and relatively prosperous one said she could not afford the price to transfer to the Phnom Penh Municipal Court (J 25, 4 December 2002).

Regarding this issue, a judge comments:

At the Phnom Penh court, there are rich people who are willing to pay bribes [when they are involved in court cases]. There are cases with potential cash. Transferring from the provinces to the city needs money. Soon after a transfer of a judge from the province to the city has been made, stories involving corruption were immediately heard.

J 13, 29 October 2002

Corrupt and incompetent judges are able to maintain their jobs because of the extensive corruption within the judicial system and the entrenched patron-client networks. 'A number of judges', a judge said, 'are incompetent. But the Ministry [MOJ] and SCM cannot dismiss them because of corruption. Some incompetent judges have money. They take [their] money to bribe those in higher authority [then] they can retain their posts' (J 10, 9 October 2002).

Interviews and conversations also reveal that bribery involves the appointment and transfer of court clerks. 'When people spend money', a clerk says, 'they have to earn money back. This is an issue that leads to corruption within the judicial system' (J 32, 19 November 2002). After 
paying an initial fixed amount of money, court officials have to maintain regular payments to their superior or patrons by buying them gifts and paying for their meals.

\section{INTERVENTION FROM THE EXECUTIVE BRANCH}

Compared to the courts under the previous communist regime, the present courts enjoy some independence. 'Under the communist regime', a prosecutor said, 'the court had no independence at all. In court cases related to serious crime, the court had to go to the party for advice. The party was the institution that determined the degree of punishment.' Currently, he added, 'judges do not ask for advice in making their judgment' (J 3, 27 September 2002). However, the court's independence remains limited. Although the court in theory can make its judgment, in reality it operates under the shadow of perceived if not real fear. For example, a prosecutor commented:

Judicial independence is not being independent in terms of materials and finance, but independent in a sense that when we have a court case, the court can judge the case according to its understanding [of the case]. Being independent in the sense that during the trial we are not afraid of their [government and individual] power. But we have not yet been able to do that. I am concerned about the pressure of the government and other individuals over the court ... For example, if the Minister of Justice said he wanted us to impose punishment at this or that level, judges had to tilt toward the minister's suggestion.

J 3, 17 October 2002

Interference by the executive branch and powerful individuals in court affairs occurs. Although reports of the frequency of interference varied from one interviewee to another, there is a general consensus that if there was intervention, judges and prosecutors needed to accommodate (J 19, 4 December 2002; J 15, 14 November 2002.). Intervention occurs on three grounds: nepotism, patronage and politics. In most cases, high-ranking government officials intervene by writing letters or telephoning judges or prosecutors. A judge said that the contents of those messages were completely legal, including phrases such as 'requesting the court to resolve the case according to the law', 'requesting the court to help look into the matter' (J 19, 19 December 2002). Sometimes, high-ranking government 
officials send their 'fixers who are connected to big people' to the court to talk directly with judges and prosecutors (J 19, 19 December 2002).

Judges and prosecutors generally acquiesce when faced with intervention by high-ranking government officials. Such submission derives from either 'affection' or fear. Affection is the product of reciprocal relationships whereby people return favors for what others did for them; such relationships have become a standard practice that is difficult to avoid in the patronage based society of Cambodia. 'Influence of intervention from a higher authority depends on the individual judge.' But the judge adds, 'Maintaining one's stance is difficult. For example, they used to help our interests. What can we do in such a case?' (J 15, 3 October 2002). It is in the sense of the desire to maintain a personal relationship and the need to maintain backing from higher authorities in the long run that stands in contrast to how 'corruption' is often conceived in the West, as a purely financial transaction.

Fear of being punished in one way or another is the most common reason cited by judges and prosecutors for their submission to interference by powerful people (J 2, 14 May 2003). While doing their work judges and prosecutors need to assess the surrounding political environment. 'In taking action', a prosecutor said, '[court officials] need to listen to the direction of the wind in order to stay alive' (J 3, 2 October 2002). Another judge expressed a similar view, saying that 'Intervention is normal. Any judge experiences this with cases over which he presides. This issue is complicated. When this issue arises, we [judges] have to think of our safety' (J 13, 29 October 2002).

Although there was no threat involved, a judge said, 'We judges have to follow because we know in advance the dimension of their power. If we do not comply, we will have a problem' (J 4, 9 October 2002). Concern over safety might include job as well as physical security. A judge admitted that such concerns affect his judgment of court cases. He said,

I want judges to be able to say precisely what they see. If they see [something] wrong, they say it is wrong. If they see [something] right, they say it is right. But in reality, judges feel really cold. If we do not compromise, they [the government/big people] can remove us.

J 24, 18 October 2002

Interventions in court affairs occur prior to, during and after the trial. Sometimes, interveners order the court to postpone a trial or delay the execution of court warrants or rulings. 'The execution of court rulings is 
a serious issue if the ruling affects "big people" [directly or indirectly]. Big people', a judge complained, 'can go to the Ministry of Justice and ask the Ministry to intervene. The Ministry then issues a letter asking the court to delay, postpone or to stop the execution of the ruling.' Sometimes, the executive branch pressures the court to arrest and imprison people.

On 21 September 2002, the chief of the Cambodian National Police ordered the arrest of the editor of Chak Kroval Newspaper and one of his staff. The police asked the prosecutor to file the charge and the judge to issue a jail warrant because the newspaper had published an article defaming the police chief. ${ }^{13}$ Because of the power of General Hok Lundy in the government and as a member of the Central Committee of the CPP, a prosecutor said, 'The court had to do it even though according to the law the judge should not issue a detention order. In normal cases, the accused can be released on bail until the trial. But because Hok Lundy ordered the arrest the judge had to follow' (J 23, 25 September 2002). Regarding the same issue, another judge commented, "The detention was not done according to the will of the judge. He did it in order to please Mr. Hok Lundy. This is a violation of human rights' (J 1, 9 October 2002).

Shortly after the issuing of the detention order, when the suspects were about to be sent to the detention centre, the news of the arrest reached Prime Minister Hun Sen, who ordered the police to release the two 'within 20 minutes'. Immediately after the order, an adviser to the Prime Minister worked diligently with the court to secure the release of the two suspects. Mr. Oam Yin Teang was quoted to have said:

The intervention of Samdech Prime Minister is not an order for the court to release Mr. Keo Sophoan and Mr. Chey Makara ... The Prime Minister's order is only directed toward the police authority; it was not an order for the court ... don't be mistaken that there was an order for the court, a branch whose independence is guaranteed within the judicial system.

Koh Santepheap 2002

This incident clearly demonstrates that the court can be twisted and turned by the executive branch. Political and civil cases are the same; as a prosecutor put it, 'If the order came from above, who dares [to question it]' (J 23, 25 September 2002). Commenting on the arrest of the journalists (discussed above), a judge said: 
The police arrested people illegally. The police arrested these people and brought them to the court. Based upon the press law, the court could not detain them. But because of the pressure from the police, I decided to issue the detention order. After detaining these people, the court released them as soon as there was an order from the Prime Minister.

J 15, 14 November 2002

Operating in a climate of impunity, where professional assassinations do occur, court officials do have legitimate concern about their own security. Such fears among court officials proved to be well-founded with the assassination of a senior judge, Sok Sethamony, in broad daylight at one of Phnom Penh's busiest intersections during morning rush hour on 23 April 2003. Like other high-profile killings, the motive behind the assassination will probably never be known. Also as in other cases, the killers will remain 'outside the net of law' (Cambodian Human Rights Action Committee 2003).

Judge Sok Sethamony had presided over a number of high-profile cases, including those of members of the so-called Cambodian Freedom Fighters, and that of a former Khmer Rouge commander (Human Rights Watch 2003). The police had their own speculations regarding the death of the judge, including 'revenge over corruption money', and 'a love affair' (Samean 2003). Although the motive for the killing is unknown, the act gravely affected the independence of the court and confirmed the fears that court officials had long had. Hing Thearith, a former PPMC judge, told a reporter that the assassination was emotional intimidation that interfered with his legal judgment, adding that 'I'm afraid that I might be killed' (ibid.). A prosecutor mentioned that immediately after the assassination of Judge Sok Sethamony, the PPMC requested the SCM and the MOJ to issue a statement condemning the killing of the judge. The two institutions refused to do so. No institution, the prosecutor complained, seemed to have the will to defend the court when it was in need of help and protection (J 2, 14 May 2003).

Among those interviewed for this study, there was general agreement that in political cases, judges deliver verdicts that fit the guidelines of the government. Some attribute judges' subordination to the legacy of the socialist past. A human rights lawyer said:

In the judicial system, judges [and] prosecutors tend to have old tendencies carried over from the communist regime. They belong to a political party 
I don't want to name. They think of the interests of their party first, their party line first. Thus, neutrality does not exist.

N 9, 1 February 2003

A judge concurs, commenting that 'The party is most important. They think of their party first; it does not matter whether they are from FUNCINPEC, CPP or SRP. What should be asked is do they dare to let their people die? No. The majority of chief judges are CPP. The CPP is in firm control' (J 19, 19 December 2002). The politicized nature of Cambodian governance makes it impossible for a neutral judicial system to emerge. Everything comes down to politics, argues a prosecutor, because 'The characteristics of politics determine the peculiarity of the court system' (J 23, 25 September 2002). Judges and prosecutors owe their careers to their parties or their patrons. Therefore, when they make any decision they have to think of, as one court official put it, 'who offered them the seat' (J 32, 20 November 2001). Consequently, 'it is unavoidable that court officials serve the interests of political parties and that the judicial system serves politics' (J 3, 2 October 2002).

NGOlawyers whom the author interviewed complained about difficulties in representing political cases. One of them said,

If court cases involve politics, I think that about 98 per cent contain judges that follow the order from politicians ... We cannot find justice for our client no matter how hard we try in presenting evidence and finding witnesses.

N 11, 2 January 2003

A senior government legal adviser once said that although the party had the power to issue an order it was up to the judge to listen to or ignore the order (J 38, 5 December 2002). It is true in theory that judges can ignore such orders, but it would be unwise for them to do so. This research shows that court officials are concerned about potential reprisals if they deviate from the standard operating procedure. A judge commented:

Everything we [judges] do has to be cautious, afraid that it might touch on the politics of the country. In some cases we implemented law; sometimes we did not dare to do that. Our country just got out of war. Lots of power is in the hands of the government. We have to be careful. Lawyers have to know politics. In cases that can seriously touch politics, we have to be careful. In some cases if we [judges] do not follow the orders [of senior government officials or government] we have trouble. We cannot resist them directly. 
Sometimes, we must assess the political situation asking ourselves how far we can go. In a place where power reigns, judges must know about politics. If they do not know, they cannot stand [in the court].

J 10, 15 October 2002

Another judge agrees that it is crucial for judges to know the working of politics in order to stay afloat, because in Cambodia law is subservient to political power. In Cambodia, a judge said, 'Lawyers have to know about politics while politicians do not need to know the law' (J 4, 9 October 2002). Generally, in political cases, government leaders can order the verdict of their choice. Citing a former President of the Cambodian Bar Association, a joint study by three human rights organizations shows that in political cases evidence is not needed; just 'advice' from the top is sufficient for making judgments (Adhoc, Licado, and Human Rights Watch 2003: 20).

\section{THE LEGITIMACY OF THE JUDICIAL SYSTEM}

Widespread corruption severely curtails the ability of the poor, who have neither money nor khnang (political connections), to seek justice. A government official compared Cambodian courts to 'a fish market' (G 11, 21 November 2001), an analogy that accurately depicts the disordered, profit-maximizing environment in which court cases are considered as fish whose price can be set or bargained. As in a fish market, cases involving the poor are metaphorically seen by court officials as bony, less juicy, low price fish that can be overlooked, resulting in many unprocessed cases each year.

The official justification for such delays is shortages of judges and resources. However, according to a court clerk, most of the unprocessed cases in 2002 were 'cases without money' (J 30, 29 September 2002). A NGO lawyer concurred, saying that 'he had difficulty with the court because he represented the poor. Because the poor had no money to pay, the court either delayed their cases or left them untouched' (N 20, 23 December 2002).

The widespread corruption within the judiciary also creates injustice for the poor when they face legal battles with the rich, because judges and prosecutors more often than not judge cases based upon the 'thinness' or 'thickness' of the stack of bribe money (J 32, 12 December 2001). In cases in which both defendants and plaintiffs are poor, the court observes the law. This occurs only when the court decides to process the case. Even if 
the case is processed, the parties involved might not receive justice in the final deliberation, because as a lawyer explained, 'Judges and prosecutors are careless, not paying attention to the case; [they] do not consider the case carefully' (J 31, 21 September 2002).

Based upon observations of trials at PPMC, a delegation from Amnesty International pointed out that 'Judges and prosecutors appear unwilling or unable to uphold Cambodian law and adhere to international standards of fairness' (Amnesty International 2003: 3). Trials were conducted hastily with little or no cross-examination from defence lawyers. The delegation also asserted that a trial for a serious charge involving multiple defendants lasted only two hours (ibid.: 5). The author's own observation of a number of trials over a period of a few months discerned a similar problem. Investigating judges either failed to conduct their own investigation or did so carelessly, making the court rely on evidence presented by the police. During a criminal trial, a trial judge complained about the investigating judge's carelessness in collecting evidence and information, commenting that 'It appears that the gentleman did his work without having any conscience. ${ }^{14}$

The combination of embedded corruption, nepotism, patronage politics and government interference engender a negative popular perception toward the judiciary in particular and government institutions in general. It is very common to hear people echo the phrase 'The court in Cambodia uses the scale to weigh money but not to seek justice. ${ }^{15}$ For example, a World Bank survey shows that the majority of Cambodians consider the court full of corruption, void of integrity and a tool for the rich and the powerful. Among those interviewed in the survey, 64 per cent agree with the statement 'the judicial system is very corrupt'; 63 per cent completely agree that 'the judicial system is only for the rich and powerful'; and 58 per cent completely agree that 'the judicial system does not deserve any trust' (The World Bank 2000: 30). A survey by AsiaBarometer at the University of Tokyo shows that the level of people's trust in government institutions is low. 34.3 per cent of respondents stated that they 'don't trust', 'don't really trust', and 'don't trust at all', government institutions (Un 2005).

\section{Attempts at Judicial Reform}

The government publicly acknowledges corruption within the judiciary and considers it a source of people's distrust of the system and an obstacle to foreign as well as domestic investment. According to Koh Santepheap, a 
pro-government newspaper, Prime Minister Hun Sen said 'Citizens have no confidence in the justice system because judges adjudicate cases based on bribery' (Koh Santepheap 2005). Consequently the government has taken a number of measures to reform the justice system.

In response to the shortages of judges and prosecutors, the government in 2002 established the Royal School for Magistrates with a plan to recruit fifty trainees for every promotion. The first promotion began in 2003. In the meantime, the government also raised the salaries of judges and prosecutors to between US\$320 and US\$400 depending upon seniority (Royal Government of Cambodia 2002). One of the major problems underlying courts' erratic nature and corruption is the absence of major laws. Responding to this issue the government has worked on drafts of criminal and civil law codes. However, while the process has been under way for a number of years, only the civil law codes have been passed, as of 2008.

Another critical reform was the amendment of Article 51. Up until 1999, government officials - civil servants, police and the military - were insulated from criminal prosecution by Article 51 of the Law on Civil Servants. Under this article, any arrest of a civil servant required permission from his or her superior. Therefore, some people considered Article 51 as a virtual licence to commit crime. A legal scholar and senior government official argued that under this article, 'Government officials, including all civil servants, police and the military, enjoyed an effective immunity from criminal prosecution' (Siphana 2002: 48).

This law provided an opportunity for collusion between suspects and their superiors resulting in many cases in which superiors ignored prosecutors' requests for the arrest of their subordinates. 'If the suspect is on good terms with the head of the department, the head did not respond to the court inquiry. We could not do anything if the department head tied our hands' (J 1, 9 October 2002).

On 18 September 1999 the King promulgated an amendment to Article 51 , which required a notification to the department heads within three days of a 'charge being filed against an employee in their departments', in lieu of prior approval from the institution (Asian Development Bank 2000: 80). However, the amendment did not address the issue of impunity in a meaningful way. The problem of impunity is linked with the wider culture of impunity that has been institutionalized. An Asian Development Bank study links impunity to the broader 'issue of the state's inability or 
unwillingness to hold itself and its officials accountable for wrongdoing' (ibid.: 81). As such, the judicial system functions with its self-generated defects as well as with impediments generated by other government institutions and powerful individuals within and outside the government.

The government's lack of political will encourages its officials and institutions to infringe on court sovereignty. 'The rule of law', a prosecutor said, 'exists only on paper. In reality, people use power not law' (J 2, 2 October 2002). The Council on Legal and Judicial Reform also raised this issue, stating, 'Regularly, judges and prosecutors experienced obstruction or threats from various circles who have power and influence' (Council on Legal and Judicial Reform 2002b: 11). The abuse of power and the continued subordination of the judiciary to powerful individuals and other institutions are the sources of widespread impunity. Judges and prosecutors do not dare to investigate all suspected cases that involve powerful individuals or their networks for fear of reprisal (J 22, 18 December 2002; J 10, 15 October 2002). A judge told the author, 'When I was studying [law] a French professor mentioned that, after reading newspapers and finding out that there were cases that might relate to public order, prosecutors in France would go to conduct investigations. Prosecutors in France dare to use their rights that are written in law.' He then asked this question: 'Does the prosecutorial institution in Cambodia dare to conduct [similar] investigations?' (J 24, 18 October 2002). The resultant effect is that the rule of law is not equally and consistently applied or enforced in Cambodia. A leading human rights leader privately told the author:

The rule of law in Cambodia exists only in name, in the Constitution, in the official statements of leaders ... It does not exist in reality ... There are two kinds of law: one for the powerful and the rich; the other is for the poor ... [If] we visit prisons, we find only poor people, not rich people.

N 6, 20 January 2003

A report by a group of human rights organizations confirms the widespread impunity enjoyed by high ranking government officials, the rich and the politically well connected. 'When suspects are arrested who have ties to high ranking officials, relatives of the suspects or others acting on their behalf may intervene to secure the suspects' release', the report says, 'either through money inducement or the intimidation of the prosecutor or investigating judge' (Adhoc, Licado, and Human Rights Watch 1999: 7). 
The most dramatic method - known as 'operation iron-fist' - was the assertion of executive power over the judiciary through the suspension and removal of judges and prosecutors, and the re-arrest of suspected criminals that the court had previously released, in the government's judgment, 'under unusual circumstances'. As a warning to the judiciary, in March 2005, Prime Minister Hun Sen stated, 'If you committed a violation, it does not matter whether you are a judge or a prosecutor, even if you are a minister, you will be arrested. If it is not done so, he will do as he wishes' (Koh Santepheap 2005). In reaction to this statement, a special commission was set up to investigate the conduct of judges and prosecutors, resulting in the temporary suspension of two judges and two prosecutors.

The government's 'operation iron-fist' might curb the erratic behaviour of judges and prosecutors; but these measures are sporadic and unsustainable. Long term sustainable measures that are crucial for democratic deepening and building legitimacy require the establishment of horizontal accountability building. Articles 132 and 134 of the Constitution entrusts the Supreme Council of Magistracy (SCM) the power to guarantee the independence of the judiciary, and to maintain the discipline of judges and prosecutors. The SCM (a supreme council that is supposed to guarantee the independence and monitor the conduct of judges and prosecutors), however, is highly politicized and under CPP control. Thus far, the CPP has not demonstrated real commitment to reforming the SCM. After all, a politicized and corrupt SCM serves their interests best. A senior official at the MOJ privately told the author that state leaders would never 'drive a post to tie themselves' by reforming the SCM (J 35, 25 September 2003).

The SCM's highly politicized nature led former King Sihanouk to distance himself from it. Son Soubert, a member of the Constitutional Council, recalled the former monarch's remarks: 'His majesty is a blind person, a mute person, a deaf person who cannot lead those people [members of SCM]' (Son Soubert, 21 June 2003). Judges, prosecutors, clerks and human rights workers interviewed by the author all agreed that the SCM is highly politicized. A judge said: 'SCM is dominated by the CPP. Those people [members of SCM] worked for their party. Since senior government officials are members of the party, they have influence over judges and the court' (J 24, 18 October 2002). Furthermore, judges and prosecutors are agents of political parties, particularly the CPP, whose leaders have a decisive influence over judges' decisions. A legal aid worker said, 'In political cases, the Prime Minister [Hun Sen] has his own network 
at the courts. According to judicial discretion, judges can rule according to his [legal] judgments; but the court listens to [CPP] politicians. For FUNCINPEC, how its network dominates [the court] I don't know; but the CPP does' (N 13, 23 December 2002).

Such a lack of horizontal accountability will not enhance human rights and protect people's livelihoods, and the creation of trust. As another judge commented:

If they let the court be independent, the court can create a mechanism to monitor the activities of individuals and the government. The government violated people's rights greatly. If the court is independent, the court can find justice for the people. I witnessed government officials who confiscated people's land and sold it to businessmen who turned it into a plantation.

J 1, 9 October 2002

More importantly, when an accountability institution such as the judiciary is subordinated to corruption-sustained patron-client networks, then the rule of law is severely affected. And consequently, democratic consolidation is hampered because the judiciary is unable to hold leaders and their clients accountable for their acts. Furthermore, rare efforts to reform the system have faced stiff resistance.

\section{CONCLUSION}

The Cambodian judicial system has been a target for domestic as well as international criticism for being corrupt, politically dependent and ineffective. However, little research has been done to examine the detailed workings of the system at the ground level. This chapter attempts to fill this gap by offering ethnographic, empirical evidence from those within the judicial system - judges, prosecutors, clerks - and those who come into contact with the judiciary - litigants, lawyers and human rights workers.

The information collected for this study reveals a picture of a judicial system which is weak, dependent and corrupt; characteristics that often delay or deny justice to the majority of Cambodians. However, such an analysis might be considered by optimists to be too harsh for a post-conflict society like Cambodia. For these optimists, Cambodia has travelled far politically, economically and socially, transforming itself from a war-ravaged country to a state of normalcy. Therefore, at the present, any expectation - with the usage of Western standards - of Cambodia having an effective, 
independent judiciary is unrealistic at the most and impatient at the least. In short, according to this perspective, Cambodia is at a transition - transition from a post-conflict society to a normal one. Transition can produce three outcomes: forward movement, backward regression or stillness. Arguably, the development of the judiciary in Cambodia, as this chapter portrays, reflects a state of glacially forward movement, if not stillness, as far as effective, independent elements are concerned. These are conditions affected by Cambodia's past dependence.

The problems within the judicial sector are a product of the broader social, political and economic environment of post-conflict Cambodia, i.e., extended clientelism and elites' half-hearted commitment to democracy. As power is structured on patronage, corruption within the judiciary is just a symptom of the problem in the wider political system. A lack of commitment to democratization obstructs the establishment of the rule of law and horizontal accountability, including a politically independent and well funded judiciary.

Rather than adopt a systematic reform of the judicial system to make it a viable, politically independent institution that could uphold the rule of law and promote political freedom, the state under CPP control initiated selective ineffectual piecemeal reform. The problems in the judiciary are endemic for two reasons. First, corruption is a practice that judges must, to varying degrees, be involved with in order to get to and continue to stay on the bench. Second, judges and prosecutors are subjected to encroachment from the executive and party leaders who can remove them from the bench if they find judicial decisions offensive.

In many ways, the judiciary is a tool of the ruling party/parties to legitimize their actions and strengthen the executive power at the expense of the principle of checks and balances. The government's recent 'mission iron grip' exercise aimed at reforming the judicial system, including the suspension of judges and prosecutors and the re-arrest of previously released prisoners, is a case par excellence. Such actions are an attempt by the government to show the public its 'commitment' to bring about social justice and order. Yet the hidden agenda of this action serves two purposes: to place the blame squarely on the judiciary and to conceal the widespread social injustice and corruption currently permeating Cambodia.

This quest for legitimacy through ad hoc reform of the judiciary, however, is not conducive to long term democratic development because it does not promote a process and mechanisms for horizontal accountability. Although 
the public denunciation of the judicial system might frighten some judges and prosecutors and hence might temporarily lessen corruption within the judiciary, such actions do not strengthen the power of the judiciary to uphold the rule of law and political liberties for the long term. Ultimately, when a fair judiciary, which is guaranteed by the Cambodian Constitution, has in reality been violated, abused and neglected, and turned into an ineffective, politically dependent and corrupt institution, it will fail to generate an equal playing field. These conditions, if they persist over time, will consequently impede the deepening of democracy and legitimacy because they undermine the rule of law and people's trust not only in the court system but also in other political institutions.

\section{NOTES}

1 See also Gunther et al. 1995: 9.

2 Author's interviews with court officials during his fieldwork revealed that such interference was extensive. These officials consistently used the phrase 'they act like during the communist era', when they were frustrated with interference from powerful individuals and other institutions, particularly the police (Fieldnotes SeptemberDecember, 2002). See also Gottesman, Cambodia After the Khmer Rouge: Inside the Politics of Nation Building, New Haven: Yale University Press, 2003, pp. 250-254.

3 This is a problem faced not only by the judicial system but also by other government institutions.

4 For the purposes of confidentiality, the letter 'J' followed by a numerical number are used to identify interviewees from the judicial system including judges, prosecutors, clerks, lawyers and officials at the Ministry of Justice. This process of masking identities is in accordance with the protection of human subjects protocols required by Northern Illinois University's Institutional Review Board.

5 Author's observation while conducting research there in 2002 and 2003.

6 Author's court attendance Phnom Penh Municipal Court, 9 September 2002.

7 The Department of Foreigners is in charge of visa and immigration affairs.

8 This judge is highly regarded by many people, both foreigners and Cambodians within and outside of the legal system, as one of the most qualified judges.

9 This comment was made in reaction to 2002 government policy to increase judges' salary but not that of court clerks. It should be noted that there are some judges who have proper legal training.

10 Foreign diplomats are identified by letter the 'D' followed by number.

11 For detail of the case see Angkear Heng, 'The President of Chilbo Industrial Co. Ltd. Congratulates Mr. Heng Peou', Rasmei Kampuchea Daily, 8 December 2002.

12 However, the author's observation and personal recollection do not support the notion that judges and prosecutors are poorer than those who occupied those positions during the PRK. 
13 For details of the story, see Koh Santepheap, 'Samdech Hun Sen Orders the Police to Immediately Release the Journalists! Mr. Oam Yin Teang Escorts Keo Sophoan from the Site of Abusive Arrest', 25 September 2002.

14 Author's observation of the trial, 23 September 2002.

15 The Khmer phrase is tulakar nov srok khmar praoe chonhching thloeng luy min men yok tov rok yutethoar.

\section{REFERENCES}

Adhoc, Licado, and Human Rights Watch (1999) Impunity in Cambodia: How Human Rights Offenders Escape Justice. Phnom Penh.

Amnesty International (2003) Kingdom of Cambodia: Urgent Need for Judicial Reform, Available: http://www.amnesty.org/library/index/engasa230042002.

Asian Development Bank (2000) Cambodia: Enhancing Governance For Sustainable Development. Manila: Asian Development Bank, Programs Department (West).

Cambodian Human Rights Action Committee (2003) 'News Release: Phnom Penh Municipal Court Was Shot to Death'. Phnom Penh 23 April.

Coren, Michael (2003) 'Strengthening the Arm of the Law'. Phnom Penh Post, 9- 22 May.

Council on Legal and Judicial Reform (2002a) Report on the Situation of Courts Throughout the Country and the Direction for Judicial Reform. Phnom Penh: Council of Ministers.

- - (2002b) Documents, Seminar on Works of Judges and Prosecutors throughout the Country. Phnom Penh: Council of Ministers.

Diamond, Larry (2003) 'What Civil Society Can Do to Reform, Deepen and Improve Democracy'. Paper Presented at the Workshop on Civil Society, Social Capital, and Civil Engagement in Japan and the United States, Tokyo 12-13 June. Online cited 20 January 2005. Available: http://www.standford.edu/ ldiamond/papers/civJa.pdf.

Donovan, Dolores A. (1993) 'The Cambodian Legal System: An Overview'. In Frederick Brown (ed.), Rebuilding Cambodia: Human Resources, Human Rights, and Law. Baltimore: The Johns Hopkins University Press, pp. 69-107.

Fernando, Basil (1998) Problems Facing the Cambodian Legal System. Hong Kong: An Asian Human Rights Commission Publication.

Fiss, Owen (1993) 'The Rights Degree of Independence'. In Irwin P. Stotzky (ed.), Transition to Democracy in Latin America: The Role of the Judiciary. Boulder: Westview Press, pp. $55-72$.

Frankel, Marvin E. (1993) 'Concerning the Role the Judiciary May Serve'. In Irwin P. Stotzky (ed.), Transition to Democracy in Latin America: The Role of the Judiciary. Boulder: Westview Press, pp. 23-33.

Gottesman, Evan (2003) Cambodia After the Khmer Rouge: Inside the Politics of Nation Building. New Haven: Yale University Press.

Gunther, Richard; Hans-Jurgen Puhle and P. Nikiforos Diamandouros (1995) 'Introduction'. 
In Richard Gunther (et al.), The Politics of Democratic Consolidation: Southern Europe in Comparative Perspective. Baltimore: The Johns Hopkins University Press, pp. 1-32.

Heder, Steve (1995) 'Cambodia's Democratic Transition to Neoauthoritarianism'. Current History, Vol. 94, No. 596, pp. 425-429.

Heng, Angkear (2002) 'The President of Chilbo Industrial Co., Ltd. Congratulates Mr. Heng Peou’. Rasmei Kampuchea Daily, 8 December.

Heymann, Phillip B. (1993) 'Should Prosecutors Be Independent of the Executive in Prosecuting Government Abuses?' In Irwin P. Stotzky (ed.), Transition to Democracy in Latin America: The Role of the Judiciary. Baltimore: Westview Press, pp. 203-224.

Howard, Dick (2001) 'Judicial Independence in Post-Communist Central and Eastern Europe'. In Peter H. Russell and David M. O'Brien (eds), Judicial Independence In the Age of Democracy: Critical Perspectives From Around the World. Charlottesville: The University Press of Virginia, pp. 89110.

Huber, Everlyne; Dietrich Rueschemeyer and John D. Stephens (1999) 'The Paradoxes of Contemporary Democracy: Formal, Participatory, and Social Dimensions'. In Lisa Anderson (ed.), Transitions to Democracy. New York: Columbia University Press, pp. $168-192$.

Khon, Pen (2000) Phnom Penh Before and After 1997.

King, Dwight (2000) 'Corruption in Indonesia: A Curable Cancer?' Journal of International Affairs, Vol. 53, No 2, pp. 603-624.

Koh Santepheap (2002) 'Samdech Hun Sen Orders the Police to Immediately Release the Journalists! Mr. Oam Yin Teang Escorts Keo Sophoan from the Site of Abusive Arrest'. 25 September.

- - (2005) 'Suspending Judges-Prosecutors: Iron Fish Shakes the Ministry of Justice and the Supreme Council of Majistracy', 25 May. Available: http://www.kohsantepheapdaily. com.kh/khmer/job08_03.htm,

Larkins, Christopher (1996) 'Judicial Independence and Democratization'. The American Journal of Comparative Law, Vol. 44, No. 4, pp. 605-626.

Makau, Multa (2001) 'Justice Under Siege: The Rule of Law and Justice Subservience in Kenya'. Human Rights Quarterly, Vol. 23, No.1, pp. 96-118.

McEvens, Kelly and Phann Ana (2000) 'Disorder in the Courts: From Highly Educated to Unschooled, Cambodian Judges are a Mixed Pot'. The Cambodian Daily, 4-5 May.

Ministry of Interior, Royal Government of Cambodia (2002) 'Memorandum to the Prime Minister'. Phnom Penh, 2 December (a copy in the author's possession).

O’Donnell, Guillermo (2004) 'Why the Rules of Law Matters'. Journal of Democracy, Vol. 15, No 2, pp. 32-46.

Phnom Penh Municipal Court (2001) 2000 Annual Report. Phnom Penh: Phnom Penh Municipal Court.

Royal Government of Cambodia (2002) Sub-decree on Salaries of Judges. Phnom Penh. 
Saing Soenthrith (2003) 'Police Search For Killers of City Judge'. The Cambodian Daily, 25 April.

Samean, Yun (2003) 'In Judiciary Some Shaken by Police Behavior'. Cambodia Daily, 1 May.

Sen, Hun (2002) Speech Delivered at the 'National Workshop on Cambodian Judges and Prosecutors'. Phnom Penh, 30 December.

Siphana, Sok (2002) 'Formulation of a Legal and Judicial Reform Strategy for Cambodia'. Phnom Penh: Legal Resource Development Center.

Stotzky, Irwin P. and Carlos S. Nino (1993) 'The Difficulties of the Transition Process'. In Irwin P. Stotzky (ed.), Transition to Democracy in Latin America: The Role of the Judiciary. Boulder: Westview Press, pp. 3-20.

Un, Kheang (2005) 'Beliefs and Perception in a Post-Conflict Society: Cambodia in 2004'. In Takashi Inoguchi (et al.), Human Belief and Values in Striding Asia. Tokyo: Institute of Oriental Culture, University of Tokyo, pp. 155-171.

Vickery, Michael (1986) Kampuchea - Economics, Politics and Society. London: Pinter/ Rienner.

World Bank (2000) Cambodia Governance and Corruption Diagnostic: Evidence from Citizen, Enterprise and Public Official Surveys. Phnom Penh: World Bank.

- - (2003) Cambodia: Enhancing Service Delivery Through Improved Resource Allocation and Institutional Reform. Phnom Penh: World Bank.

World Development Report (2006) Equity and Development. New York: Oxford University Press.

Zakaria, Fareed (2003) The Future of Freedom. London: W.W. Norton \& Company.

\section{INTERVIEWS}

D 1, interview with author, Phnom Penh, 6 June 2003

G 11, interview with author, 21 November 2001

J 1, interview with author, Phnom Penh, 9 October 2002

J 2, interview with author, 14 May 2002.

$\mathrm{J} 2$, interview with author, 2 October 2002

J 3, interview with author, Phnom Penh, 27 September 2002

J 3, interview with author, 29 September 2002

J 3, interview with author, 2 October 2002

J 3, interview with author, 17 October 2002

J 4, interview with author, 9 October 2002

J 6, interview with author, Phnom Penh, 16 August 2002

J 7, interview with author, 10 March 2003

J 7, interview with author, 3 October 2002

J 9, interview with author, 4 December 2002

J 10, interview with author, 9 October 2002 
J 10, Interview with author, 15 October 2002

J 13, interview with author, 29 October 2002

J 14, interview with author, 21 October 2002

J 15, interview with author, 3 October 2002

J 15, interview with author, 14 November 2002

J 16, interview with author, 28 October 2002

J 19, interview with author, 4 December 2002

J 19, interview with author, 19 December 2002

J 22, interview with author, 18 December 2002

J 23, interview with author, 25 September 2002

J 24, interview with author, 18 October 2002

J 25, interview with author, 4 December 2002

J 30, personal conversation, 29 September 2002

J 31, interview with author, 21 September 2002

J 32, interview with author, 19 November 2002

J 32, interview with author, 20 November 2001

J 32, personal conversation, 12 December 2001

J 34, interview with author, 25 August 2002

J 35, conversation with author, Phnom Penh, 25 September 2003

J 37, personal conversation with author, 28 December 2002

J 38, interview with author, 5 December 2002

J 40, interview with author, 27 September 2002

N 9, interview with author, 1 February 2003

N 6, interview with author, 20 January 2003

$\mathrm{N} 11$, interview with author, 2 January 2003

N 13, interview with author, 23 December 2002

N 20, interview with author, 23 December 2002

Son Soubert, interview with author, Kandal Province, 21 June 2003 


\title{
Chapter 4
}

\section{Decentralization as a Strategy for State Reconstruction in Cambodia}

\author{
Kim Sedara and Joakim Öjendal
}

As is noted in chapter 1 of this volume, the dominant approach to solving prolonged internal conflicts in the post-cold-war era has been through international interventions followed by a rushed 'democratization', implemented via multiparty elections and adhering to standard democratic procedures ( $c f$. Ottaway 2002; Paris 2004). Once a peace agreement has been reached, the 'irresistible' rationale of this approach has been to rapidly insert a political regime aiming at bridging previous internal strife and thereby counteracting a structural contestation of political authority. It has been widely recognized that before any reconstruction in war-torn societies can commence, a viable political system needs to be crafted, capable of producing a government which can - in addition to winning a democratic election - earn the 'moral right to rule' (Barnes 2001). ${ }^{1}$ Without a broadly accepted re-establishment of a system for political authority, there exists no 'post-conflict' phase, and no viable possibility for applying subsequent measures and support for 'post-conflict reconstruction'.

There is, however, a contradiction inherited in the rapid insertion of a 'democratic system' on the one hand, and the sustainability of the very same process on the other. Typically for countries coming out of an internal war, democratic values are not widespread, institutions are not developed, and few powerful internal interests are prepared to defend 'democracy' when/if it no longer constitutes the optimal equilibrium point for the key actors' interests ( $c f$. O'Donnell and Schmitter 1986). Civil society is typically disempowered in light of the preceding violence, constituting a weak force in the immediate aftermath of war (eg. Blunt and Turner 2005; $c f$. Orjuela 2002). As is now mounting to a general criticism, the short-term needs to 
solve conflicts and introduce a post-conflict process come frequently into conflict with the long-term demand for stability, democratic sustainability, and the building of stable regime legitimacy; instead they may prepare the ground for renewed conflicts. Once international intervention ends, the increased political competition aggravates sectarian politics, creating a divisiveness resembling the initial situation. The result may be a process which produces neither political stability nor sustainable democracy. Hence, it is argued, the tentative democracy fails to become consolidated, semiauthoritarian interests take over, allowing for neo-patrimonial relations, and a widely spread corruption. Along this line of arguing, a massive criticism of rapidly inserting democracy as a means to conflict resolution and postconflict reconstruction has emerged (Paris 2003; Ottaway 2003; Bastian and Luckham 2003), and indeed a general over-belief in democratization as an inevitable process is common ( $c f$. Carothers 2002).

Cambodia seems to fit this picture: after a 'big-bang' insertion of democracy in 1993, political crises emerged in 1994, 1997, 1998, 2003 and 2005/6, just to mention the most obvious. The much hoped-for democracy is generally seen as deviating towards some kind of 'hybrid' regime (Carothers 2002; Hughes and Kim 2004; Ojendal and Lilja 2006) containing a fair amount of the democratic institutions (such as regular elections and a liberal constitution), but nevertheless at large operating outside accepted democratic norms, values and procedures. Instead of slowly but steadily improving, the process is seen by some as one which is slowly but steadily returning to autocratic rule after a window of democracy (Heder 2005; $c f$. Ashley 1998; Chandler 1998). Some even argue that democratization was a train that never left the platform (McCargo 2005).

The general as well as the particular criticisms of Cambodian democratization have in common that they primarily view democratization at the national level. This approach seems to be widely shared by actors promoting the intervention paradigm, global policy-makers and most analysts alike. As necessary as they may be, agreements between actors at central level and the rapid establishment of national multiparty elections will in themselves build neither sustainable peace nor consolidated democracies (Romeo 2002; Woodward 2002; Paris 2004; UNDP 2002; Diamond 1999). In the words of Michael Doyle:

Traditional strategies of conflict resolution, when successful, were designed to resolve a dispute between conflicting parties. Successful resolution could be measured by the stated reconciliation of parties, the duration of the 
reconciliation, and changes in the way parties behaved toward each other. But successful contemporary peacebuilding doesn't just change behavior; it also, and perhaps more importantly, transforms identities and institutional contexts.

Doyle 1998: 382

Instead, if successful post-conflict reconstruction is to take place through the consolidation of liberal democracy, more in-depth processes need to be initiated, institutions need to be built, civil society needs to be engaged, and, in the long run, political culture needs to be altered (Doyle 1998; Diamond 1999).

While criticism of the quality of Cambodian democratization and limitations of the success of Cambodian reconstruction is usually well founded (Heder 2005; McCargo 2005; Peou 2000; Peou 2007), there are simultaneously more 'grounded' political processes evolving where values such as participation, accountability, representativity, and transparency are taken more seriously, or so it seems (Mansfield 2004; McAndrew 2004; Öjendal 2005; Öjendal and Kim 2006; Evans 2000; cf. Slocomb 2004; Prum 2005; Rudengren and Öjendal 2002; Ayres 2004; Pellini and Ayres 2007). Admittedly, one has to look deep for these more progressive processes in order to find them, since they do not dominate the immediately visible political space in Cambodia. However, most observers agree (as above), the process(es) involved in what can loosely be labelled the 'decentralization process' are too real and too interesting to be ignored, and are possibly, as this chapter will argue, having an influence far beyond their immediate local ambitions.

The decentralization reform, including local elections and participatory methods, may have appeared irrelevant in 'high politics', but its progressive political values impacts inevitably on the majority of the people and promises (but cannot guarantee) to be exactly what the insertion of national democracy was not, namely grounded, understood, localized and defended (see below for a further argument). Moreover, it has for a decade been driven from below/within, making it one of the few political reforms which are 'owned' by the government. In a way, this process has already contributed to a certain degree of enhanced political legitimacy, and brought politics 'down' to regular people and 'out' to the local arenas ( $c f$. Öjendal and Kim 2006). However, as is commonly noticed in the literature, decentralization (and local democracy for that matter) is a double-edged sword where the shifting of focus in politics always serves certain interests and hides others. 
In the highly politicized atmosphere of Cambodia, the decentralization reform is not only a 'soft' reform with the above-mentioned features and aims, but also a tool in a much harsher national power politics. ${ }^{3}$ In fact, as it turns out, and as we shall see below, the entire reform has partly emerged due to realpolitik at the national level and may in fact also result in highly charged alterations in political systems at the national level. In other words, there may be a 'perfect match' between 'hard' central politics and 'soft' local politics.

This chapter attempts to illuminate to what extent the ongoing decentralization process, with its local election and package of political and development ambitions, constitutes a progressive change where democratic values are spreading and political regime legitimacy is being harnessed. In other words, we aim to assess if the political change at local level may be a genuine start of a long-term political reconstruction phase where authorities bit-by-bit earn the 'moral right to rule', hence overcoming endemic public mistrust in government authority and long-term legacies of political division. The underlying suspicion is that it may be that, hence constituting the seeds for the 'real' democratization and a sustainable reconstruction process in Cambodia, although it constitutes a struggle that may take several decades to complete.

Below, we analyse the process leading up to the current phase of decentralization, including its political and hidden agendas. This is followed by a review of the content of the reform and what we know of its implementation so far. With a historical perspective, we then outline the critical issues for the local process and account for our empirical input. Finally, we put the local issues into a national context and draw our conclusions for its role in post-conflict reconstruction. First, however, we review some theoretical writings on the impact of a 'local approach' to processes of political reconstruction.

\section{THEORETICAL UNDERPINNINGS OF THE ROLE OF A LOCAL APPROACH}

Any state machinery is dependent on a particular balance between the central powers and mandates and their local counterparts (Turner 1999). In such a view, the 'decentralization-recentralization' struggle is ever ongoing, and constantly in need of 're-negotiation'. However, in a post-conflict context this 'balance' deserves enhanced attention. Peace agreements are very 'central' accords, whereas a lot of the burden of the violence (and of 
the subsequent reconstruction) remains with the rural areas, implying that the task of rebuilding political legitimacy is greatest in the rural areas. In a UNCDF conference on the topic it was observed that:

Civil wars occur within local communities and it is in rural areas that most of the destruction takes place. Local governance approaches are thus particularly suited to immediate post-war conditions, as long as they are designed to achieve the main priorities of peacebuilding.

Romeo 2002: 3

Romeo adds that 'the reconstruction of local polities [is] an integral part of the process of reconstructing the state. In a sense, the state itself cannot be reconstructed on solid grounds without addressing and resolving the issue of central-local relations.' (Romeo 2002: 4).

Moreover, this argument is also embedded in the comprehensive model for achieving long-term reconciliation outlined by Lederach (1997: 39). He states that:

One could argue that virtually all of the recent [successful] transitions toward peace ... were driven largely by the pressure for change that was bubbling up from the grassroots. In fact, at times, it seems that exhaustion, rather than innovative planned transformation, is chiefly responsible for ending conflicts.

Lederach 1997: 52

In his view, the central-to-local axis is the key, emphasizing upward and downward links (and he does not regard national elections as sufficient). In the case of Cambodia, the political culture does not allow for any 'bubbling up'. However, as we shall see, given an opportunity, the increased political space is much appreciated at the local level, and may also in Cambodia carry political power.

The 'local' approach is also used in reconstruction in the same sense as Kaldor (1999), i.e. if good and civil governance cannot be guaranteed in the entire system, at least 'islands of civility' in certain areas can be attempted, in the hope that these should 'spread' in due time. This argument is important for Cambodia; the political system will not turn accountable, transparent and fair overnight. Quite the contrary; due to a historical legacy of excessively violent experiences, mistrust, vested interests, patronage politics and threats of renewed violence permeate politics. The political practices are harsh, especially for the weak and vulnerable. Ledgerwood 
makes a crucial point when she argues that general trust is so low that it is only in small circles that people trust each other and the public, and that beyond these small circles relations collapse in a vicious circle of selffulfilling processes of distrust. In addition, the emerging cash-economy further fragments any perception of a 'natural' local reciprocity (Kim 2001). Hence, any rebuilding of trust and political legitimacy demands a 'local' approach where endemic social fragmentation can be countered. Hence, there is a case for encouraging circles of reciprocity which are so 'small' and transparent that the give-and-take between the civil society and the state is identifiable (Ledgerwood 2002). This distrust has been observed before, as well as being a recurrent theme in Cambodian political history. In the widest possible perception, 'legitimacy' has never been an important dimension of Cambodian political history. Political control has been achieved through force and to the extent that force vanished, the rulers have lost political control, but with the introduction of 'democracy' in 1993, political legitimacy has turned into an important political factor. To amass support 'from below' seems now to be an innovative, dynamic and possibly powerful way of introducing legitimacy into Cambodian political history; a political history that has few, if any, experiences of peaceful transformation of power. Power rests typically with individuals or groups, but not within public state institutions.

However, within academia, few attempts to study and evaluate this 'local approach' have been made in relation to processes of political reconstruction in the aftermath of the outbreak of large-scale violence. Practitioners' experiences are plentiful, but these experiences are far from unequivocal, highlighting both the risks of simplification and that of donor failure. In fact, a local approach may constitute a threat to peacebuilding and instead create 'decentralized despotism', allowing for local elite capture, an (over-) politicized civil society, or other conflictual processes depending on demographic, ethnic or other imbalances that may be enhanced through disconnecting local and central levels (Mehler 2002: 73; Woodwards 2002). ${ }^{4}$ However, also in benevolent circumstances a number of factors are of crucial importance for achieving a positive impact from a local approach to reconciliation and reconstruction. The five factors below were gathered through a screening of the existing literature and can be understood as a 'state-of-the-art' hypothesis on the local approach to political reconstruction: 
1. The nature (or 'type') of conflict and conflict resolution is crucial. A 'collapsed' state may need to reconnect state authority with civil society through local level reassertion of the state, whereas an ethnically based conflict may (or may not) be acerbated by decentralized initiatives (Mehler 2002).

2. Any approach needs to be culturally adapted and not steered by external or instrumental interests pursuing alien models of little relevance for, and little chance to be understood in, the particular context ( $c f$. Hasselskog, this volume; $c f$. Rist 1997).

3. Central-local relations must be maintained. Local/decentralized levels must not be detached from central level authorities; i.e. they must not be left to themselves without checks and balances and without the possibility for the central level to intervene. Or to take it further: the very point of a decentralized approach is to establish the link between central and local level in the reconciliation process (Romeo 2002).

4. The intervention/reform must aim at, or at least be designed on the basis of, political reconstruction, either through concrete local level conflict resolution or through the establishment of a democratic and legitimate local government, which acknowledges the need for enhanced legitimacy and trust, and which also actively works to remedy these deficiencies (cf. Rigby 2001; Doyle 1998).

5. That the overall political-economic context is supportive is imperative, where technical support and resource access is necessary, and where a dimension of economic development is preferable. (Woodwards 2002)

Thus, our interest in political reconstruction - in contradistinction to conflict settlement - has obliged us to make a difference between an analysis of peace agreements and foreign interventions involving (only) national elites and predominantly viewing the short term, and has led us to consider under which conditions and with what means a more 'grounded' approach may add value and substance to a process of political reconstruction (Doyle 1995; Finlay 1995; UN 1995; cf. Lederach 1997: xvi). Below, we look closer into the case of Cambodia in order to form an opinion on the above discussion on the role of the 'local' approach to political reconstruction. The overall assumption is that decentralization may contribute to enhanced political legitimacy at the local level, which in turn may support democratization and overall political reconstruction. We investigate this first through a review of the process leading up to the decentralization reform, which will be followed by an account of empirical data relevant to this issue, before we consider the effect of the 'local approach' on political reconstruction in Cambodia so far. 


\section{THE EVOLUTION OF DEMOCRATIC DECENTRALIZATION IN CAMBODIA}

The political reform of local governance, which followed in the path of the first election in 1993, has constituted - at best - a 'stop-and-go' process. Until 1998, the ambitions were high (RGC 1994; cf. Bruce St. John 1995: 267), but the actual pace of reforms was slow. ${ }^{5}$ One early important exception to the pattern was a major development project named Seila, which was initiated in 1996 in order to promote local development and to rebuild confidence in the state through encouraging and supporting the local administration to enhance its performance. ${ }^{6}$ In many localities, appreciation of the changing attitude and activities of the local state was evident (Eastmond and Öjendal 2000). Evans et al. have summarized the political legacy of Seila thus:

There is no doubt in our minds that SEILA has succeeded beyond expectations. Most importantly, SEILA has visibly changed attitudes. Communities have become more active and self-reliant, provincial and district government staff have become more responsive to community needs. Put differently, SEILA has made notable progress in promoting democratic values and good governance ...

Evans et al. 2000: 1

Subsequently and by default - not by intent - this turned into one of the flagships for UNDP in their quest to be a leading agency in peacebuilding (UNDP 2002). In fact, the experiences of this 'experiment' subsequently inspired the nation-wide decentralization reform, which by now occupies centre stage in terms of public administration reform (RGC 2001; Bautista 2002; Sokha 2005), and not only in itself, but perhaps largely due to the dynamic effects of that reform (see further below).

\section{Content and Process of the Reform}

While the legal framework for this reform, too, was delayed several times, the laws on both 'Commune Administration' and 'Commune Elections' were passed in the spring of 2001, and the first local elections in modern times were held in February 2002. This process of decentralization aims formally at enhancing local political participation and improving service delivery for addressing rural poverty issues. ${ }^{7}$ The reform introduces locally elected Commune Councils with a range of powers: the Commune Councils have inter alia the right to tax, ${ }^{8}$ write laws, administer some local resources, receive a share of the national budget, and receive development resources from external actors. The Commune Council is formally independent of 
District and Province administration, and answers directly to the Ministry of Interior (MoI) at the national level. It may be seen as modest, but in the Cambodian context - especially compared to the pre-1993 situation - this is a paradigmatic shift in political practices and rationality.

Since the 'big-bang democracy' of UNTAC was obviously not grounded (it was 'invented', implemented and left to itself within 18 months), only through a reform of local governance was the process started of a substantive democratization process, and of the 'real' political reconstruction process. Whereas national politics with its democratic shortcomings (Heder 2005; McCargo 2005) have brought a certain resignation and alienation on the part of the broad public, the decentralization reform has, generally, empowered and inspired people in rural areas. In the process, fear and suppression has gone down markedly (Öjendal and Kim 2006). In essence, it has opened a positive dialogue between the people and the state, and introduced a seed of democratic culture. This may in the big scheme of things be a more solid sign of a break with 'politics as usual' than the national elections ( $c f$. Roberts 2001: 78f). In the commune elections people voted for something that they could actually see the direct result of, and it is likely that these elections, far more than the national ones, served to put some confidence in election matters. It may even be the case that the rural population will now get some real influence over how resources are spent; if so, it would truly represent a shift in Cambodian political practice. Hence, there should be little doubt that the decentralization reform has political significance, as well as democratic potential. But, if it is so atypical in the family of (socalled) reforms during the last decade, as well as in the political culture of Cambodia, why is it at all pursued?

\section{Why a Reform of Democratic Decentralization?}

Seila, when it was initiated, drew a lot of criticism that it worked with bottomup and participatory methods that were deemed too alien and idealistic, and that the communes were run by (what was generally understood as) 'thugs' loyal to the dominant party (Ledgerwood 1998; cf. Thion 1993). The decentralization reform itself likewise faced severe criticism and suspicion when it was first presented (Meixner and Sovirak 1999). And understandably so: not only was it against the mainstream political culture of Cambodia, but it also seemingly made little sense in contemporary politics: why would the dominant party (CPP) introduce a deep democratic reform when it was struggling to minimize the democratic space at national level in order to 
retain and consolidate power? Why would the commune level, previously being the hard-core institution of maintaining political control (and repression) in the rural areas, be made the primary agent for a reform of participatory development and local democratization? Our explanation of these legitimate queries is paradoxical and multi-dimensional.

Firstly, there was hardly any turning back from complementing the national election in 1993 with a local election of some sort. This ambition was stated very early, already in 1994, although at the time in a much smaller costume. When the first drafts on future local election emerged, it was already considered as very late, and the government had to come up with something not to lose credibility.

Secondly, the long time lag between the national elections and the start of the political reform of the rural areas was becoming increasingly awkward. Social and political stability in the rural areas in the 1980s was - in want of political legitimacy - achieved through a mix of political authoritarianism, patronage politics (plan-economy style), and popular fear of violence. Following the first national elections in 1993, the former and the latter were naturally bit-by-bit being reduced, and loyalty through patronage could hardly be kept up without financial benefits and political power being vertically disseminated through the system. In addition, liberal economic reforms were introduced, increasing social and physical mobility in the rural areas, and further challenging a local, stable, patron-client system. In short, political control over the rural areas was rapidly eroding. This was also realised by the Ministry of Interior (MoI) quite early:

Since the Cambodia Government was formed [Sept 1993], it has generally been observed that the commune authorities within some provinces seem to be reluctant to perform their duties and tasks, and that their commitment towards the responsibilities of managing the administration and public security in local areas has [loosened]. The main reason for these [problems] is that they are waiting to see the outcome of the election of commune [authorities] as prescribed in the National Constitution of the Kingdom of Cambodia.

Ministry of Interior, Instruction No. 324, May 10, 1994, unofficial translation

That the MoI was convinced that the grip of local administration had been continuously degenerating was subsequently confirmed (MoI, Interview, November 2000). This was historically the power base of the CPP and 
losing control over rural areas would eventually imply loss of power also at national level. Hence, somehow, local administration had to be given a greater and more solid mandate from which it could continue to operate, but at the same time apply a political strategy acceptable to the new times.

Thirdly, there were vested interests within the state administration regarding economic and political influence in the rural areas. Quite unexpectedly, to safeguard the rural vote had become politically important. The people assuring the majority of votes from the rural areas would also be mandated to form the government (with some 85 per cent of the population residing in rural areas). On the economic side, there was a vast flow of aid resources emerging aimed for the rural areas, and those controlling these resources would also be able to command substantial patronage. The fact that $\mathrm{MoI}$ was pursuing this reform could be understood as a way to re-take ground that had been politically and economically lost to the line ministries, which gained strength when authoritarian politics of necessity increasingly turned towards 'development', engaging primarily social and economic sectors such as health, education and rural development. The practices established under Seila with funds earmarked for the commune level, as well as the taxation rights and the right to an annual budget outlined in the Commune Administration law, re-arranged resource flow and resource generation.

Fourthly, and the most intriguing part of the system change, once the Commune Councils turned out to be CPP-dominated in the first election, ${ }^{9}$ the commune became a key level for local politics. For instance, via the village chief - formally a non-official - and through existing patronage structures the popular vote for CPP at commune and national level was assured, largely within a democratic framework: i.e. without exercising 'violence' but through a combination of the distribution of petty benefits and a semi-aggressive social control, the Commune Council-village chief link is likely to assure a majority of votes for CPP at both commune and national level. Moreover, feeling confident in the overwhelming majority in the Commune Councils, it has been made into a 'catapult' for further political reforms; the Councils are already appointing village chiefs, voting for the Senate, and are likely to be the key instance for electing district and provincial councils (see further below).

So, there is a tension in the reform, between the 'soft' progressive aims and the 'hard' political strategy. It is in general an empirical question which of these will be dominant in the development of the 'hybrid democratization' 
and reconstruction of Cambodia. Let us turn to these empirical issues, first with an historical perspective.

\section{THE HISTORICAL ROLE OF THE COMMUNES AND DECENTRALIZED AUTHORITY ${ }^{10}$}

Before the arrival of the French in 1863, Cambodia was a 'traditional state' with patrimonial power exercised directly from the royal court, from which the central power was spread out only to areas close to the capital (Sreang 2004). The French administration from 1870-1946 attempted to establish a 'modern' form of government in the country. Under the reign of the King Sisowath (1904-1927), the Khum (the commune) was created by the French largely, serving the interest of the colonial administration. At the time, as far as local administration was concerned, the Khum was administered by a Cambodian commune chief or me khum, assisted by some lower officials (Sarraut et al. 1929).

It is not clear whether Commune Councils were popularly elected or not. A French historian (Forest 1980) recounted that the commune chief, or me khum, was elected by villagers alongside the approval of the provincial governor. It is, however, unlikely that the common villagers would have had much say in the matter. Obviously, the establishment of the Cambodian communes was controversial and the Khum at that time was assumed to become one of the most important governmental institutions in supervising local administration (Simon 1919).

The 'commune' wasinvented as a way of strengtheninglocal administrative governance and establishing the state's presence in rural and remote areas. It was further hoped that the administration would be brought closer to the people while simultaneously making it more efficient (Roome 1998: 17). In spite of being established by a Royal Decree as early as 1908, the commune authority made little difference in the short run. The communes remained secondary to the villages as a source of identity. When a new local Decree was issued in 1925, a 'community council of councillors' (kromchumnum) was outlined wherein the me khum was the chairman who 'decided the affairs of the Khum, assisted by his deputies (chumtup) (Homont, taken from Roome 1998: 18). However, the combination of decrees, central control and numerous guidelines resulted in a rigid system of central control instead, and the kromchumnum did not achieve much. 
The turbulent times of the 1940s and 1950s caused great uncertainty in terms of local administration, including first a de-democratization and later a French-inspired attempt at increasing local democracy through a circular in 1955. This was later followed by a 'Kram 340 NS of 1 September 1959', which outlined:

... out of concern to see ... people granted true democracy [and] to promote the people to direct participation [in] the affairs of the state ... This law gives the citizens a right of control over the management of local affairs.

Quoted from Roome 1998: 20

It seems, though, that at different times, in different provinces, 'real' elections were occasionally held for commune chiefs (field notes). At the time, it was seen as a deep democratic reform, in line with modern political thought. However, the gradually harsher political climate of the 1960s prohibited any implementation of the spirit of reform. In spite of the shortcomings, the reform of 1959 seems to have been one of the major influences on the present reform work (Setha, interview, November 2000).

During the Sangkum Reastr Niyum regime (the Sihanouk regime, 1953-70), the legitimacy and possibly the presence of the commune chiefs, commonly referred to as 'fatherly figures', seems to have been fairly high. However, they were only moderately involved in promoting development, and the source of their relative legitimacy was their identity as the local arm of the King (or Sihanouk as Prime Minister) rather than their promotion of local development. Tax and data collection seem to have been the primary activities they tended to. During the Lon Nol period (1970-75), the role and function of the communes declined and was de facto substituted during the Khmer Rouge years by other mechanisms of control and coercion.

During the post-Khmer Rouge era, the administrative system was strengthened with Vietnamese assistance and the communes, as the 'lowest' administrative level, were given an important role in the reconstruction and 'grounding' of the state, as well as for its defence. It is to be noted that commune elections were actually carried out in some places in the early 1980s ( $c f$. Vickery 1986). However, the commune authority became largely an instrument for political control and for the mobilization of both forced labour and the recruitment of soldiers, operating with authoritarian and crude methods; this was especially important in the provinces that continued to come under Khmer Rouge attacks, mainly in the West part of the country ( $c f$. Slocomb 2001). Through the locally mobilized militia, the 
commune level was also a key component of the local defence. This also led to a considerable number of Vietnamese advisers/military officers working closely together with the commune chiefs. In the eyes of the villagers, this generally served to further delegitimize the commune chiefs (Commune Chiefs, Interviews, Battambang and Pursat, October 1999). During the 1980s, the commune authorities did not have much autonomous power, except as an arm of the District authority. Both District and Commune chiefs were the local military commanders, which even now impinge on political legitimacy. Commune chiefs readily admit that their close relation to the Vietnamese became a problem in terms of legitimacy, but most reject the idea that they still are associated with the Vietnamese military (field notes).

The renovation of the state in 1989 ('State of Cambodia') caused few or no changes in the legal framework or the practical work of the commune administration (except that it coincided with the withdrawal of the Vietnamese military). As noted above, the major overhaul of the Cambodian constitution and political life in 1992-93 meant surprisingly little for the commune administration, and virtually nothing for local democracy in the immediate term. The size of the commune administration was reduced, their role became increasingly elusive and the methods at their disposal progressively limited. As argued above, political control exerted from the commune level was disintegrating, and the commune authority's political capacity was degenerating, and most likely its political legitimacy too.

Curiously, there is a crude similarity between the situation at the turn of the twentieth century and the one at the initiation of the contemporary reform: there is limited success in nation-state building; a political elite that is as dependent on outside forces as on internal dynamics; the communes are progressive but weak as administrative units; and the central state has only an elusive presence in the rural areas. Although vertical power has always been strong, the current push is not the first time that the commune level has been utilised as a space for increasing state legitimacy. Will it succeed this time?

\section{REBUILDING POLITICAL LEGITIMACY AT COMMUNE LEVEL?}

As we noted above, most empirical work so far indicates a cautious optimism regarding the early progress of the reform (Mansfield 2004; McAndrew 2004; Öjendal 2005; Öjendal and Kim 2006; Evans 2000; cf. Slocomb 2004; 
Prum 2005; Rudengren and Öjendal 2002; Ayres 2004; Pellini and Ayres 2007). This literature has, however, in common that its empirical base is limited (which it shares with most social science research in Cambodia), and for our purposes it is of limited assistance, since little of it explicitly concerns issues of reconstruction and the rebuilding of political legitimacy. The analysis below is based on quantitative material collected in 2005-2006 and qualitative material from three separate fieldworks from 2003-2006, and benefits from a long-term interest in these issues, equally shared by the authors. The quantitative material spans 583 random interviews in 5 communes in 5 provinces, and with 73 commune councillors in the same provinces. The selection of the 5 provinces is such that it constitutes a geographical spread and, as far as possible, a wide political representation.

As usual, there is no baseline to truly measure change by. ${ }^{11}$ However, the combined historical reporting on the role and perceptions of the commune authority overwhelmingly indicates distance (Chandler 1991; Roome 1998), alienation (Eastmond and Öjendal 2000), ruthlessness (Slocomb 2001; 2004), and fear (Öjendal and Kim 2006; cf. Luco 2003). A massive majority of the testimonies in interviews and life stories points out either that commune authorities used to be distant and irrelevant, or present and scaring. Equally, the deep historical sources tell the same story of state power (Chandler 1991; Mabbett and Chandler 1995; Vickery 1986; Martin 1994). The dominating historical understanding from regular villagers is that any state agency is frightening and should be avoided as far as possible (cf. Hasselskog 2000). A number of surveys have been made the last decade pertaining to the performance of the Commune Councils (Mansfield and MacLeod 2004; MacAndrews et al. 2004). While no systematic baseline has been drawn, there is sufficient scattered evidence to assert that the relation between commune authorities and villagers has not been close, caring, filled with respect, and/or one of harmony of interest. ${ }^{12}$ The hypothesis of this chapter, which contradicts these views, is that the decentralization and the local elections are introducing a new rationale for local government. This is neither an instant, nor an unproblematic process, and we will present empirical evidence that reflects a reality that deviates from the historical pattern and defends this claim. Below, popular perceptions, Commune Council perception, and political analysis will be the general categories under which this hypothesis will be scrutinized. 


\section{Changing Popular Perceptions of the Commune Councils?}

One of the recurring themes in the literature describing the difficulties of any sort of democratic or participatory governance in the rural areas in Cambodia is the distance between regular people and the state authorities, which is marked by fear and coercion, at times by endemic hostility. Our figures indicate a distinct deviation from that theme. In our survey, more than 90 per cent claimed that they knew the name of the current commune chief, almost as many knew the name of some other councillors, and 61 per cent said they were comfortable seeking out the commune authorities if they had a problem. A staggering 96 per cent claim that anyone can approach the commune authorities and 68 per cent believe that the Commune Council is able to maintain a positive and viable relation to civil society over time.

Taken at face value, this indicates that the degree of distance and alienation is minor, contradicting the regular reports on fear and avoidance; in fact it seems like most people give the authorities at least the benefit of the doubt in this new situation. A word of caution should be inserted here though. Although this survey was carried out by the most qualified people available, there is a cultural difficulty in triggering critical responses from regular Cambodians; especially vis-à-vis the state. However, while this is true for both cultural and historical reasons, it is a clear perception among surveyors and researchers alike that the degree of outspokenness is currently quite high, and definitely much higher than it used to be. ${ }^{13}$ Although a major change is detected here, social and cultural structures do not change easily. Hence, the relationship between electorates and state authorities remains a daunting issue at the grassroots level in Cambodia. People may still view local leaders as the formal state powerholders. A member of Village Development Committee in Siem Reap reccounts:

The gap of the relationships between citizens and authorities is still not closely interactive. I do not know why people normally prefer to stay away from authority. People do not go and meet or ask authority unless something unavoidable. However, people in this commune do know all of the $\mathrm{CC}$ members and they mostly respect those CCs as their leaders

VDC member, Bakong Commune, Siem Reap, 24 April 2000

Moreover, looking into the degree of change itself, there is without doubt a perception of change in the local arena. 53 per cent thought that the commune election had implied an immediate change (whereas 39 per cent disagreed), over 70 per cent thought that in their minds the Councils 
had been democratically elected, and more than 90 per cent confidently stated that they could vote the Commune Council out of power at the next election if it did not perform to expectations. A group of elder people explain their impression of the Commune Council:

Since the commune election in 2002, it is very different from the previous system in terms of leadership which was a very top-down approach. However, the decentralization of the Commune Councils is bottom-up, and decisions do not rest with an individual who is normally the chief, but decisions must be made by all councillors.

A group of elder people in Battambang, 27 April 2006

A massive 87 per cent think that the commune councillors respect ordinary people and almost 92 per cent think they (try to) deal with problems that people present them with. The latter is a clear indication that, if nothing else, the general atmosphere in the villages has changed from one of tension, repression and insecurity ( $c f$. Luco 2003) to one of relative stability, predictability and 'tolerance' (cf. Öjendal and Kim 2006). An argument we met was that there is emerging 'a culture of tolerance' within the work of, and civil society's relation to, the Commune Councils. This contrasts starkly with previous anthropological reviews of fear and vertical repression from the side of local authorities (Ovesen et al. 1996). A commune chief and councillors in Kompong Speu express their view on a culture of tolerance as:

People are still used to the culture that power rests only with the chief and our society has been lacking of culture of tolerance (khmean kar sondos pranei). But since the commune election, all different political parties can work together and especially each of us, to be the benevolent leader, must rule by mutual tolerance (samak thor). This culture of tolerance is gradually emerging now among the commune councillors.

Commune chief and councillors, Kompong Speu, 3 April 2006

Moreover, there is also an emerging discourse at the local level, on the growing diligence on the side of the local authorities, where korob ('respect') is replacing klach ('fear') as the main characteristic of the Commune Councils. ${ }^{14}$ Pro peiy ni nueng anarthor doch kang ro tes trauv te mean pi was another Khmer saying we came across, freely translated as 'Khmer culture and state authority are the two wheels in an oxcart, supporting one another'. This is a different way to describe the alteration in the perception of the 
Commune Councils, in that it sensitively calls for/describes a soft relation between popular Khmer culture and state authority. Such description would never have been used to describe the prior situation in rural Khmer villages. Now, over 70 per cent of the respondents say that there clearly is a more harmonious atmosphere in the villages, as compared to the period of the first democratic election. This has to a large degree to do with the ceasing of the civil war, but more than a quarter of the respondents trace this change to the emerging decentralization reform in one way or another. A majority believes that the Commune Council has actively accomplished local level reconciliation through education, helping solve minor conflict and simply being honest with people. A well-respected elder person, who is also Achar Wat, describes the nature of Cambodian farmers' perception of the local state as follows:

Personally, I think Khmer do not like to change their leaders; they do not trust the new ones coming in to replace the old ones. This makes them not frequently switch political party. You often see during the election campaign politicians always providing gifts. Our culture is not doing something bad to the gift provider and we must pay back sometimes (doeung kun) (respect someone's favour). And people still believe in karmar: to be a leader that person must have accumulated merits from his or her previous life.

Achar Wat and Farmer in Battambang, 3/May 2006

It seems that, drawing on the above, the 'hard' aspects of politics - repression, carelessness, neglect, violence, fear - are to a large extent quelled, reformed, or at least subdued for the moment.

Other problems emerge though. Of the people who are not feeling that there has been any change due to the decentralization reform, more than 50 per cent blame poverty and social turbulence as the key reason. What we heard increasingly during our fieldwork was that petty corruption is on the rise, and almost 50 per cent claim that the Commune Councils are corrupt. Another emerging issue is commune chiefs' limited physical presence in the villages; the current problem is that they seem to be absent rather than distanced. Almost 70 per cent of the respondents say that the commune chief comes to their village once a month on average and that they then have meetings and disappear quickly. Only some 30 per cent think that information is disseminated in a transparent way. This should, however, be balanced by the facts that 70 per cent believe that their Commune chief is well informed about the situation in the villages, that 57 per cent believe that 
development projects and the auspices of the commune authorities benefit most villagers, and that more than 50 per cent answer that the Commune Council 'always' help to mediate and (attempt to) solve conflicts (and 92 per cent say that the Commune Council always deals with the situation somehow).

The real problems may however relate to the role of the commune authorities in the overall state administration. They are to a large extent supposed to be 'independent', while operating in a political culture based on vertical patronage structures, putting them in a vulnerable situation, when/if they try to act out their 'independence' (Kim and Öjendal 2007). It is, moreover, commonly argued that the Commune Councils cannot deliver 'development' because their lawfully defined powers have not been fully enacted and that the reform of the rest of the state administration is lagging behind, impeding the development potential of the Commune Councils from being realised. ${ }^{15}$ This is so either due to lack of funds, or due to inadequate administrative routines. Hence, they cannot deliver what they are supposed to be able to deliver. People also tend to identify this pattern: only 30 per cent think that the Commune Councils have enough power to be responsive vis-à-vis the needs of the citizens. Corruption (or at least its perception) is, as mentioned above, understood as growing, which is a recognizable pattern also in other cases where political pressure is loosening, and in the answers there is a non-dominant, but still discernable, undercurrent that the Commune Councils are putting up facades of good governance only, and in reality have invented a much more 'efficient' way of exploiting villagers. A recent research study has identified how liberal economics, political culture and vested party interests coincide into a neopatrimonial pattern, securing privileges for the elite, while at the same time still pursuing the cornerstones of liberal democracy (Pak et al. 2007).

\section{Changing Roles of the Commune Councils?}

Initially, one of the presumed major obstacles to a successful (in any aspect) decentralization reform was initially generally understood as the views (attitudes, behaviour, memories) of the commune authorities and in particular the commune chiefs. There are now, however, several reports repudiating this view, even holding up the progressive work of the Commune Council as a key to the reform. Although most of them by necessity have drawn their conclusions after only a very short period of operation, they put the agency of the commune authorities at the forefront. 
Below we review the councillors' current attitudes and perceptions on local governance, legitimacy and reconciliation.

First of all, in the view of the councillors, there is no doubt whatsoever that there is a massive change in the forms and practices of governance as compared to before the decentralization reform, as almost everybody stated that there has been a major general overhaul, and 93 per cent stated that the exercise of power is distinctly different now. They see two key changes: Firstly, there is a multiparty system with a political debate (of sorts) even at local level. It seems beyond doubt that on one level, repressive politics and the previous atmosphere of fear has vanished. There are many councillors in the council, implying that there is less of a threat of rot am nach (state authoritarianism); i.e. the despotic, autocratic exercise of power so strongly associated with previous commune chiefs. Secondly, and most importantly according to the poll, there is explicit bottom-up thinking and practice integrated in the new system. While the latter could be seen as being at odds with the ingrained political culture, commune councillors generally express relief at not having to be autocratic, repressive and despotic, but instead being 'allowed' to seek protection and/or support behind the popular will.

Interestingly, under the new regime, 96 per cent of the commune councillors think they can manage their task well; 81 per cent think that the multiparty system - the introduction of openly competitive politics at local level - has posed no problems, and 84 per cent believe that powersharing within the Commune Council has not been an issue. This is extremely interesting, given how many problems were foreseen with the role of the commune chiefs and the politically divided Commune Councils. Interestingly, the commune chiefs/councillors are brimming with selfconfidence. The problems they see are twofold. The most obvious is the lack of funds to properly respond to the articulated needs of the people. To open the participatory process, market the idea of decentralization aiming at development gains, and then have no resources available to respond to (most of the) demands is awkward, and in the long run hollows out the legitimacy and reconciliatory effect of the reform. More than 80 per cent of the interviewed councillors think that this is the key problem of the entire reform. In terms of 'getting it right', 85 per cent of the councillors believe that there is a match between local demands and their development policies, and 75 per cent think that their policy is carried out with accountability, 
under a transparent regime, creating good relations between the commune authorities and people at large.

The second difficulty the commune councillors typically see is that they are not vested with a proper mandate to fulfil their task (73 per cent). The tax-raising ability they are vested with is not yet realisable due to the stalling of the reform of the Ministry of Economy (who are keen not to lose their monopoly on taxation, and are worried about unfettered corruption). This is thoroughly bothering 81 per cent of the councillors. Their political authority is also undermined by the fact that the overall civil service reform - which would harmonise the role of the District and Provincial authorities with that of the Commune Councils' - has not yet been launched, ${ }^{16}$ implying that the Commune Councils are left as isolated islands surrounded by the 'old' political style. In fact it seems that there is an honestly felt frustration on the part of the commune councillors that they cannot better enact the new philosophy in their work.

A third difficulty - stated by outsiders - may be that the loyalty of the commune councillors is unclear. By law they should be accountable to the people who have put them in power, work in close collaboration with the rest of the state administration, and report to the Ministry of Interior. However, it is generally assumed that loyalty to the respective party - on the part of the individual commune councillor - is at times stronger than any other alignments, especially in times of 'hard' politics (including times of election). Some 76 per cent of the commune councillors say that they are primarily accountable to the people, but it is also a common complaint that the commune councillors only serve 'their group' [bomreu krom robos klourn], hence (re-)inserting patronage politics in the new order. It is also evident in the answers of the commune councillors that many of them question who their boss(es) really is (are), the answers being distributed equally between 'District', 'National Level', and 'Other' (while 'Political Party' and 'The People' receive only a minor share).

Political legitimacy is building up. The commune authorities generally state that the best way to get the trust of the villagers (which almost everybody agrees is necessary for the winning of the next election) is to work with transparency [doy tomlar pheap], honesty [smos trang], and with a humble approach [heung min prokan kloun]. That 74 per cent of the population are dissatisfied with the quantitative responsiveness (in terms of projects and development) to the citizens' demands is understandable (encompassing the entire issue of poverty), but it is more interesting that 
the quality of responsiveness (encompassing the skills with which it is performed) is deemed as 'satisfying' or 'very satisfying' by 90 per cent of the population.

In sum, local politics seems to have considerably changed in quality, including the image of the commune authorities. This has provided the state (and as it were, the party; see further below) with a considerable boost in term of credibility and legitimacy. These gains are primarily made through political processes. Any tangible success is yet to be found in the realm of development and poverty alleviation. This is however explainable through the little funding (relative to the demands) available for commune projects, and the immenseness of the task. However, it is our conviction that there are more layers to this cake, as we reveal below.

\section{A Change in Local Politics?}

As a consequence of the historical vertical power relations, the distance between ruler and ruled is great in contemporary Cambodia. In several surveys it has been concluded that the commune authorities historically have been seen as a distant and dangerous authority for most Cambodians (Öjendal 2000; Eastmond and Öjendal 2000), reinforcing the generally held view that authorities are best avoided and that ordinary people can only lose from coming in contact with them. In contrast, it is now reported that villagers frequently look up the Commune Councils on their own initiative and discuss their problems with the commune office. Even more interesting, since the communes still have few resources to support the needy, they say that the only way to get respect from the villagers is 'to be totally open. This is our only defence' (field notes). The key differences from the 1980s (when there was a war) and the 1990s (when the communes had no development mandate and no democratic dimension) is that at the time the commune authorities had to increase distance and fear in order to maintain their position (since their work method was not understood as legitimate), while now the rationale is to narrow the distance in order to obtain legitimacy. Judging from the above, in most places these processes seem to have begun.

So far, it is reasonable to conclude that the establishment of Commune Councils has created a pluralistic political space, while at the same time it has not increased horizontal conflicts. The decentralization reform has also started a process whereby the local state is getting increasingly accepted as a legitimate authority, and possibly one which may be able to deliver 
services and induce processes of local development. As such, the eightyear-old decentralization reform outpaces the sixteen-year-old national democratic reform.

However, it would be overly naive to leave it with that. Though it is clear that local politics have changed, it is also clear that there are no simple democratic forms emerging. It is generally understood that the village chief - formally a non-official - exerts considerable social control, and it is likewise generally understood that the village chief knows which family has voted for which party. ${ }^{17}$ The village chiefs are popularly understood as belonging to the dominant party and they are since 2007 selected by the Commune Councils (which are dominated by CPP). With a defunct state machinery in the 1980s, in a state of civil war, legitimacy could not be coerced, but under a politically benign regime, with a development ambition and in command of resource flows, the dominant party turns into an attractive 'patron' (or at least the only credible one).

Or put differently, from the individual peasant's perspective, as long as political ideology does not play a role there is neither any other party that is more likely to deliver benefits, nor are there any major drawbacks for supporting CPP. Quite the contrary, to not support the major political party, in the long run - when a land conflict emerges, when there is a need to borrow money, or when Food for Work assignments are distributed - may prove detrimental to the individual interest. And as everybody 'knows', there is no other party present at the local level with a capacity to deliver either benefits or security. At bottom, there is still a deep mix of party and state affairs, keeping up a long 'tradition' in Cambodia. In addition, veiled threats, petty vote buying, future promises, the power of minor gifts, and other - in the context - minor pressures become extremely efficient in gathering the majority of the vote, especially in combination with the historical fact that $\mathrm{CPP}$ is seen as the main political actor with superior access to coercive mechanisms (security apparatus, police, military). In other words, in a local setting, if a vote for the right party can buy a favour, some security, or some patronage bonds, it may, for the politically uninterested peasant, be the best use of their voting rights. And since nobody really expects politicians to alleviate poverty - too many political ideologies have failed to deliver that over the last four decades - the 'trading' of the vote is for many an easy choice, which may actually render a real benefit at the end of the day.

So, in essence, the democratization of local politics, including soft governance and participatory methods, may have opened up for a 'return' to 
patronage of the 'old kind', which isbased on individual 'choices' andeconomic benefits, ${ }^{18}$ distinct from a more politically commanded patronage during the socialist era. According to liberal theorizing, a liberal environment will guarantee that non-democratic practices - such as patronage structures with demands on reciprocity in terms of voting preferences - are disclosed and prevented as a result of public pressure. However, in rural Cambodia there is hardly any such 'public pressure' defending the finer shades of democracy ( $c f$. Kim and Öjendal 2007). Rather, the remaining poverty, a low degree of education, and the prevailing political culture push peasants towards the seeking of 'protection', and in acquiring that protection they can use a new currency attractive to the elite, namely their political allegiance. Hence, the 'small' paradox (explained above) is that the introduction of soft local governance, including local elections, reinforces the viability of 'nondemocratic' practices along the lines of patronage; the 'large' paradox is that the introduction of local democracy may essentially produce a nondemocratic consolidation of power by the dominant party at national level. The rationale behind the latter claim we disclose below.

\section{THE POLITICAL CONSEQUENCES OF DEMOCRATIC DECENTRALIZATION}

The net effect on democratization of decentralization is not clear; rather, it is multi-stranded and contradictive. On one level, it is obvious that decentralization is successful beyond expectations in supporting democratization and generating political legitimacy at the local level. However, it may also be the case that ultimately, it is cementing a particular political power structure which is not primarily associated with 'democracy'. Reconstruction of sorts may nevertheless be taking place in the wake of the changing local politics, calling into question the not always noted incompatibilities between reconstruction and democratization.

\section{Decentralization as a Means to Enhanced Political Legitimacy and Local Democratization}

It is beyond doubt, we argue, that the previous political repression and the violent politics in rural Cambodia have been replaced by more soft forms of governance, and that a fair share of that is to be attributed to the decentralization reform. People are not afraid of the local government, they respect it to a far higher degree than they used to, and they are generally convinced that it can be replaced with democratic means in the next 
election (and they do not doubt that there will be a next election). There is also a political pluralism of sorts emerging, and public participation is encouraged. Irrespective of whether one assumes a minimalist democratic definition (the possibility of choosing political leadership in a process including real options), or whether one assumes a more comprehensive approach to democracy (including the socio-political climate, the degree of structural violence, and the actual possibilities for parties to contest power), democracy in the local arena has increased considerably. Given the sentiments and debate around this reform only five years ago, and given the general perception of the significance and harshness of Cambodia's political culture, this is nothing less than a major progression.

Having said that, as we see further below it is equally clear that subtle forms of political pressure are applied, possibly being more efficient than harsh political repression ever was in eschewing any 'natural' outcome. However, although classic vote-buying may occur, other more sophisticated social pressures are applied, most of which would hardly be considered illegal even in western democracies, and are very efficient in the context of rural Cambodia. These would include the distribution of minor gifts, free car rides to registration and voting stations, and free meals in relation to campaign activities, but also (semi-)coercive measures such as hints from local authorities that the vote is not secret, that future benefits will be reduced, and that local state services such as conflict resolution and mitigation will be limited. While these relative minor interferences may seem innocent, in the context of poverty and little political education, and a history of authoritarianism, this may actually make a major difference, and it definitely constitutes a limitation on the idea of an ideal local democracy. More regular features of rural Cambodia also cause the quality of democracy to fall: lack of education, poor campaigning, indirect limitations on party formation, and little ideological interest/debate. Many of these features are, however, structural, meaning that they will be there for the foreseeable future, irrespective of what regime is in place and what legal framework is implemented.

The explanation for the alteration in the democratic content of local governance is partly to be found in the national democratization, but to a large extent the decentralization reform has deepened democracy and the degree of participation. Analysing the empirical data reviewed above, it is clear that there have been immediate effects from the reform, and that perceptions of democracy and regime legitimacy have changed from the 
side of the commune councillors as well as from the general population. It may be safe to state that the commune level is the part of the civil administration that has experienced the most solid change and been going through a rather successful (initiation of a) civil service reform. However, as we will see below, this is no guarantee for overall democratization.

\section{Decentralization and its Consequences for Overall Democratization}

From the above we can determine that a) the political control of the rural areas was degenerating in the 1990s and needed to be enhanced; b) the decentralization reform is genuine, with a direct impact on the quality of local governance; $c$ ) the local administration and the overall state machinery have experienced a legitimacy boost. These are the obvious facts, which are by now empirically quite well confirmed.

This process has been led from the MoI, which is dominated by CPP interests. For the first election, the 'democratic' approach was, from their point of view, a gamble. To let go of authoritarian control and replace that with a democratic and decentralized structure is neither a part of the political culture of Cambodia nor of CPP. Still it was pursued.

The first election resulted in massive support for CPP. Once this was a fact, the commune authorities were made the cornerstone of democratic reform in the administration, and used as a platform for the consolidation of power by the ruling party. Firstly, the communes themselves constitute a key level in the nexus between the state and the people. As such the party that controls the Commune Council controls the key institution for the interaction between these two arenas. Secondly, solving a controversy, the Commune Councils were made the key institution in the voting for the members of the Senate ('Senate Election Law'). While the Senate is not politically powerful, it has quite a lot of political status and comprises the senior political elite in the country. In a culture where seniority is highly respected, this is significant. Thirdly, after some debate, the commune councillors have been made responsible for selecting village chiefs. And although, according to a sub-decree, that should be done with respect for popular demand, in reality every village chief will be holding his/her position in gratitude to the Commune Council. Fourthly, in the process around the public sector reform - focusing on reform at the provincial and district level - both the district and provincial councils will be politically elected by the commune councillors too, possibly giving them a leverage over these levels, while giving the overall administration a flavour of democracy. 
Hence, taking the massive support at the commune level, and assuming that it is not likely that this support will lessen any time soon, it seems 'safe' to utilize the Commune Councils as a means of responding to demands on further democratization, with the dominant party still not risking a loss of power. While the elections at commune level are of high quality from a technical perspective, the political elite seems to manage to combine in an efficient way the prevailing political culture with the limitations of fully exercising democratic practices at local level, crafting a predictable election result; a result not from cheating, but also not from a fully fledged democratic culture. This is seemingly a watertight system, not likely to open up to drastic changes in the near future, yet carrying a certain democratic credibility.

\section{Decentralization as a Means to Political Reconstruction?}

Seen from a local perspective, decentralization, in combination with consolidated perceptions of peace, has turned into an impressing tool for the returning of life to some kind of normality. In fact, the ongoing democratic decentralization is - as was pointed out in chapter 1 - not a 're'-construction of something existing previously, but rather an invention, a political experiment thoroughly restructuring local governance, and local politics at large. Decentralization with democratic content has been attempted before in Cambodia, but is has never sunk in, instead being disrupted by other political changes. Now, elements so typical in postconflict societies such as fear, insecurity and political repression have markedly - not to say drastically - gone down, and democracy and popular participation in political processes have improved steeply. Poverty reduction is slow and generalized trust at the local level is suffering from legacies of the long conflict(s), as well as from the nature of the three decades of continuous violence.

The current democratic decentralization has had impacts outside the commune level. That is, outside the local arena(s) commune elections have served to re-establish (invent) a political system that has brought perceptions of a democratizing system and satisfied both radical and popular demands for the further deepening of democratic reforms. And, as we saw above, a large part of the reforming political system is hinged on the commune level and its already established democratic practices and forms. As such, the democratic decentralization can within the political realm be seen as the primary measure for re-constituting legitimate institutions and political 
authority, and civil service efficiency, in the system as a whole. In this view, the decentralization reform gains unexpected weight and significance, and turns into a key policy measure for political reconstruction.

\section{THE ULTIMATE PANACEA OR YET ANOTHER CUL DE SAC?}

The reform of democratic decentralization is rather successful. However, a closer look reveals that not all aspects of the reform fulfil expectations. Firstly, the enhanced democratization expected from the reform has seemingly emerged already. The indicators on democratization reviewed above are doubtlessly impressive. Although some latitude may be given the tendency of the respondents to reply 'too positively' when asked a political question, the figures do not leave much room for doubting that there has been a real political change, given the nature of the previous political systems. In the local arena, a degree of democracy has risen as a result of the democratic decentralization reform. And it seems to be sustainable in the sense that most people view it as unrealistic that the reform will be reversed and the situation return to the previous one.

Secondly, democratic decentralization seems to work well as a tool for post-conflict reconstruction. While this is an undefined process and a loose concept, the fact that fear and violence have been reduced considerably in the villages must be seen as a key process in moving from a phase of conflict to one of 'post-conflict'. As a result, a certain degree of stability is now found in the rural areas.

Thirdly, political institutions of a democratic nature have been directly and indirectly established (or are about to be). This is extremely important in a reconstruction context since this is a typically weak link in the policy measures associated with the reconstruction chain.

However, a fourth expected outcome of the reform is more intriguing. According to most expectations, national level democracy should be boosted by this reform. And it may in the long run. However, as we saw above, currently, the democratic decentralization has created a political body that is subject to mild, but efficient, political manipulation. While this does not necessarily have very serious local effects, through the leverage of the Commune Council appointing representatives at several other levels, it turns into a nationwide concern. The net result seems to be a thorough cementing of the dominant party position: i.e. CPP received the overwhelming majority of the votes at the first commune election 
and could therefore comfortably make the commune level the political base for reforming the political system. To many, that would be seen as an undemocratic net effect of the reform.

Unexpectedly, then, post-conflict reconstruction (thriving under decentralization) and national level democratization (hesitating under decentralization) emerge as different processes, on different tracks. This further underlines the criticism of big-bang interventions aiming at rapid democratization as a strategy for post-conflict reconstruction, as reviewed at the beginning of this chapter. It may on the other hand reinforce the argument ( $c f$. Lederach 1997) for the necessity of a bottom-up approach to political reconstruction.

All in all, in a political sense, this reform is probably the most progressive and successful of all current attempts at rebuilding statehood in post-conflict Cambodia. It is explicitly driven from within, and the most grounded of all the civil service reforms. While we remain critical of the idea of bigbang democratizations expected to solve all post-conflict reconstruction problems, it is nevertheless clear that without a national level liberalization, democratic decentralization would not be taking place. Hence, there is a dialectic relation between 'big' democracy and 'small' democracy, although neither linear, nor deterministic. The relation may not be, at all, what was expected.

\section{NOTES}

1 Although Thailand in no definition is a 'post-conflict' country, the coup d'etat in late September 2006 illustrated well the difference between winning elections and having a broad legitimacy. The growing strife between Fatah and Hamas in Palestine is another case in point.

2 As many commentators have pointed out (e.g. Paris 2004; Ottaway 2003; Woodward 2002) 'post-conflict' is not really a good term since no society is really ever 'postconflict'. Instead, 'post-violence' or 'post-war' would be more accurate. However, in line with the current debate, and with this reservation, we will also use the term 'postconflict'.

3 As we will see below, decentralization is not an isolated phenomenon, but one integrated into 'high politics', and a part of a 'D'n D-reform'; i.e. a package of decentralization and deconcentration aiming eventually at a total overhaul of the state machinery (see 'Strategic Framework for Public Sector Reform', 2005, RGC, Phnom Penh).

4 We are not, however, of the view that decentralization is about 'disconnecting' central and local levels. Rather, decentralization is about giving the local level the power to balance and inform the national influence, and thereby enhance the quality of overall governance. 
5 Others are extending this point even further, arguing that the Cambodian political culture is incompatible with a liberal democratic system and it is not a question of democratic reforms being 'slow' but just evidence that they will not take place (Bruce St. John 1995: 297; Mehmet 1997, passim). While such an argument may have historical precedence, it may overstress the determinism of culture over politics ( $c f$. Hughes et al. 2006).

6 Seila in turn built on 'CARERE', a development project led by UNDP with roots in UNTAC. It aimed to facilitate refugee repatriation through supporting local communities and was in operation from 1992 to 1996.

7 Formally the aims are: i) To promote pluralist participatory democracy at the local level through the creation of popularly mandated and autonomous local governments. ii) To promote the culture and practice of participatory development (planning, management, resource mobilization) at the local level through the Commune Councils. iii) To contribute to the reduction of poverty by improving services and their delivery. (Thematic paper by the Deputy Prime Minister Sar Kheng presented at the National Symposium on Decentralization and Local Governance on May 15-16 2002).

8 This is stated in the law. However, necessary sub-decrees for operationalizing this have so far been withheld by the Ministry of Economics and Finance.

9 At the time, this was a gamble for CPP. The first election was generally deemed democratic, but the only party with a historical base in the rural areas was CPP, hence they gained the majority of the votes. However, they only got 38 per cent of the votes in the first national elections, and many commune authorities (led by CPP) were genuinely unpopular at the time. CPP could well have lost. In order not to do that, prior to the election they substituted a vast number of unpopular old commune chiefs with locally legitimate, informal leaders and engaged its patronage chain with full force to draw the votes. They succeeded beyond anyone's expectations and gained 61 per cent of the votes and 68 per cent of the chairs in the Commune Councils, and the majority of the commune chief positions. Funcinpec was second with 20 per cent of the councillors, and Sam Rainsy Party third with 12 per cent (Mansfield and Macleod 2004).

10 This sub-section is mostly based on Öjendal and Kim (2006).

11 The fieldwork accounted for below constitutes in a way a baseline which will later be followed up. As such it constitutes the first phase of a longitudinal study of the impact of the decentralization reform.

12 For a philosophical discussion on various aspects of this relation then and now, see Öjendal and Kim (2006).

13 The utmost effort has been taken to establish a good rapport with the local population.

14 See Öjendal and Kim (2006) for a description of these terms and their political significance.

15 Note that this hesitancy pertains to affairs outside the commune; inside the commune the commune chief and the village chiefs are by more than 70 per cent believed to possess the real power, and some 95 per cent of the commune councillors think they have decision-making power on local development issues.

16 At the time of the final review of this work, the draft of 'Organic Law' was made public, addressing several of these issues. 
17 In a strict sense this is probably not true. However, the election results on commune level can be lead back to the village level, and once the voting pattern in the village has been determined, qualified guesswork can actually disclose (with some degree of certainty) dissident families.

18 These are real choices of sorts, although under structural pressure from poverty and insecurity.

\section{REFERENCES}

Ashley, David (1998) 'The Failure of Conflict Resolution in Cambodia: Causes and Lessons'. In Frederick Z. Brown and David G. Timberman (eds), op. cit.

Ayres, David (2004) 'NGOs, Partnerships, and Local Governance in Cambodia: Discussion paper', The Commune Council Support Project (CCSP), Phnom Penh.

Barnes, Samuel H. (2001) 'The Contribution of Democracy to Rebuilding Postconflict Societies'. American Journal of International Law, Vol. 95, Issue 20.

Bastian, Sebastian and Robin Luckham (2003) Can Democracy Be Designed? The Politics of Institutional Choice in Conflict-Torn Societies. London: Zed Press.

Bautista, Ernesto, Sak Setha and Prum Sokha (2002) 'Decentralizing the State'. Paper presented at The Second International Conference on Decentralization, Manila, 2527 July 2002.

Blunt, Peter and Mark Turner (2005) 'Decentralization, Democracy and Development in a Post-Conflict Society: Commune Councils in Cambodia'. Public Administration and Development, Vol. 25, No. 1, pp. 75-87.

Brown, Frederick Z. and David G. Timberman (1998) Cambodia and the International Community - the Quest for Peace, Development, and Democracy. Singapore: ISEAS.

Bruce St. John, Ronald (1995) 'The Political Economy of the Royal Government of Cambodia'. Contemporary Southeast Asia, Vol. 17, No. 3.

Carothers, Thomas (2002) 'The End of the Transition Paradigm'. Journal of Democracy, Vol. 13, January.

Chandler, David (1991) The Tragedy of Cambodian History: Politics, War and Revolution since 1945. New Haven and London: Yale University Press.

- (1998) 'The Burden of Cambodia's Past'. In Frederick Z. Brown and David G. Timberman, op. cit.

Diamond, Larry (1999) Developing Democracy: Towards Consolidating. Baltimore and London: Johns Hopkins University Press.

Doyle, Michael W. (1995) UN Peacekeeping in Cambodia: UNTAC's Civil Mandate. Boulder, Colorado: Lynne Rienner.

- - (1998) 'Peacebuilding in Cambodia: The Continuing Quest for Power and Legitimacy'. In Frederick Z. Brown and David G. Timberman, op. cit.

Eastmond, Marita and Joakim Öjendal (2000) The Role of the Commune in Participatory Development in Rural Cambodia. Stockholm: SIDA. 
Evans, Hugh et al. (2000) Strategic Evaluation of CARERE. Stockholm: SIDA.

Finlay, Trevor (1995) Cambodia: The Legacy and Lessons of UNTAC. Stockholm: SIPRI.

Forest, Alain (1980) Le Cambodge et la Colonization Francaise: Histore d'une Colonization sans Heurts, 1897-1920. Paris: L'Harmattan.

Hasselskog, Malin (2000) Local Governance in Transition: Villagers' Perceptions and Seila's Impact. Phnom Penh: CARERE.

Heder, Steve (2005) 'Hun Sen's Consolidation: Death or Beginning of Reform?' In Southeast Asian Affairs (Yearbook). Singapore: ISEAS.

Hughes, Caroline (2003) The Political Economy of Cambodia's Transition, 1992-2001. London: Routledge.

Hughes, Caroline, Joakim Öjendal and Kim Sedara (2006) 'Introduction: Tradition vs. Progress? Rethinking Culture and Power in the Context of Internationally-Sponsored Reform'. Symposium on 'Cambodia: Reassessing Political Culture in Times of Political Change'. Journal of South East Asian Studies, Vol. 36, Issue 2 (July).

Hughes, Caroline and Kim Sedara (2004) Evolution of Democratic Process and Conflict Management in Cambodia: A Comparative study of Three Cambodian Elections. Working Paper 30. Phnom Penh: CDRI.

Kaldor, Mary (1999) New and Old Wars: Organized Violence in Globalized Era. Cambridge: Polity Press.

Kim Sedara (2001) 'Reciprocity: Informal Patterns of Social Interactions in a Cambodian Village Near Angkor Park.' MA dissertation, DeKalb: Northern Illinois University.

Kim Sedara and Joakim Öjendal (2007) Where Decentralization Meets Democracy: Can Civil Society Enhance Accountability from Local Governments in Cambodia? Working Paper 33. Phnom Penh: CDRI.

'The Law on the Administration and Management of Commune/Sangkat' (2002).

'The Law on the Election of Commune Councils' (2002).

Lederach, Jean-Paul (1997) Building Peace. Sustainable Reconciliation in Divided Societies. Washington DC: United States Institute of Peace Press.

Ledgerwood, Judy (1998) 'Rural Development in Cambodia: The View from the Village'. In Frederick Z. Brown and David G. Timberman (eds), op. cit.

Ledgerwood, Judy and John Vijghen (2002) 'Decision-Making in Rural Khmer Villages'. In Ledgerwood, Judy (ed.), Cambodia Emerges from the Past: Eight Essays. DeKalb, Il: Northern Illionois University Press.

Luco, Fabienne (2003) Between the Tiger and the Crocodile: A Social Anthropological Approach to Traditional and New Practices of Management of Local Conflicts in Cambodia. Phnom Penh: UNESCO.

Mabbet, Ian and David Chandler (1995) The Khmers. Bangkok: Silkworm Books.

Mansfield, Christine and Kurt MacLeod (2004) Commune Council and Civil Society: Promoting Decentralization through Partnership. Phnom Penh: PACT. 
Martin, Marie Alexandrine (1994) Cambodia: A Shattered Society. Berkeley: University of California Press.

McAndrew, John (2004) Experiences of Commune Councils in Promoting Participatory Local Governance. Phnom Penh: CCC.

McCargo, Duncan (2005) 'Cambodia: Getting Away with Authoritarianism?' Journal of Democracy, Vol. 16, No. 4.

Mehler, Andreas (2002) 'Decentralization, Division of Power and Conflict Prevention: A Theoretical Exploration with Reference to Africa'. In Tobias Debiel and Axel Klein (eds), Fragile Peace: State Failure, Violence and Development in Crisis Regions. London: Zed Books.

Mehmet, Ozay (1997) 'Development in a War-torn Society: What Next in Cambodia?' Third World Quarterly, Vol. 18, No. 4. pp. 673-686.

Meixner and Sovirak (1999) 'Decentralization in Cambodia'. Cambodia Daily, issue 91, November 6-7. Phnom Penh.

O'Donnell, Guillermo and Philippe Schmitter (1986) Transitions from Authoritarian Rule: Tentative Conclusions about Uncertain Democracies. Baltimore: Johns Hopkins University Press.

Öjendal, Joakim (2000) 'Sharing the Good - Modes of Managing Water Resources in the Lower Mekong River Basin', Göteborg: Padrigu Papers (PhD dissertation).

- - (2005) 'Decentralization as Political Commodity in Cambodia'. In Francis Loh and Joakim Öjendal (eds), Deepening Democracy and Restructuring Governance: Responses to Globalization in Southeast Asia. Copenhagen: NIAS Press.

Öjendal, Joakim and Kim Sedara (2006) 'Korob, kaud, klach: In Search of Agency in Rural Cambodia'. Symposium on 'Cambodia: Reassessing Political Culture in Times of Political Change'. Journal of South East Asian Studies, Vol. 36, Issue 3 (October).

Öjendal, Joakim and Mona Lilja (2006) Hybrid Democracy and the Processes of Change: the Political Transformation of 'Installed Democracies'. Stockholm: Research Application to Sida/Sarec.

Orjuela, Camilla (2003) 'Building Peace in Sri Lanka: A Role for Civil Society?' Journal of Peace Research, Vol. 40, No. 2, pp. 195-212.

Ottaway, Marina (2002) 'Rebuilding State Institutions in Collapsed States'. Development and Change, Vol. 33, No. 5, pp. 1001-1023.

Ovesen, Jan, Ing-Britt Trankell and Joakim Öjendal (1996) When Every Household is an Island - Social Organizations and Power Structures in Rural Cambodia. Uppsala: Research Reports in Cultural Antropology.

Pak, Kimchoeun et al. (2007) Accountability and Neo-Patrimonialism in Cambodia: A Critical Literature Review, Working paper 34. Phnom Penh: CDRI.

Paris, Roland (2003) 'Peacekeeping and the Constraints of Global Culture'. European Journal of International Relations, Vol. 9, No. 3, pp. 441-473.

- - (2004) At War's End - Building Peace after Civil Conflict. Cambridge: Cambridge University Press. 
Pellini, Arnaldo and David Ayres (2007) 'Community Participation in Local Governance in Cambodia: Learning from the Village Networks Approach'. Development in Practice, Vol. 17, No. 3, pp. 404-409.

Peou, Sorpong (2000) Intervention and Change in Cambodia: Toward Democracy? New York and Singapore: St Martin's Press and ISEAS.

- - (2007) The Limits of Democracy Assistance: Toward Complex Realist Institutionalism. Tokyo: Sophia University Press.

Prum, Sokha (2005) 'Decentralization and Poverty Reduction in Cambodia'. Regional Development Dialogue, Vol. 26, No. 2, pp. 114-120, Autumn.

RGC (1994) National Program to Rehabilitate and Develop Cambodia. Phnom Penh: MoI.

- - (2001) Governance Action Plan. Phnom Penh: MoI.

Rigby, Andrew (2001) Justice and Reconciliation After the Violence. Boulder, London: Lynne Rienner.

Rist, Gilbert (1997) The History of Development. London: Zed Books.

Roberts, David W. (2001) Political Transition in Cambodia 1991-99: Power Elitism and Democracy.Richmond: Curzon Press.

Romeo, Leonardo (2002) 'Local Governance Approach to Social Integration and Economic Recovery in Post-Conflict Countries'. Paper presented at conference on A Local Governance Approach to Post-Conflict Recovery, New York, 8 October.

Roome, Patrick (1998) Assistance to the Ministry of Interior on Basic Legislation for Decentralised Commune Councils. Phnom Penh: UNDP/RGC.

Rudengren, Jan and Joakim Öjendal (2002) Learning by Doing: An Analysis of the Seila Experience in Cambodia. Stockholm: Sida.

Sarraut, Madrolle and P. Gourou (1929) Connaissance de L'Indochine: Vietnam, Cambodge. Hanoi: Laos Conseil de Recherches Scientifiques de L'Indochine.

Simon (1919) A Book about Cambodian Royal Affairs: The Judiciary and the Administration. Phnom Penh: Imprimerie du Protectorat.

Slocomb, Margaret (2001) 'The K5 Gamble: National Defence and Nation Building under the People's Republic of Kampuchea'. Journal of Southeast Asian Studies, Vol. 32, No. 2, June, pp. 195-210.

- - (2004) 'Commune Elections in Cambodia: 1981 Foundations and 2002 Reformulations'. Modern Asian Studies, Vol. 38 (2), pp. 1-21.

Sokha, Prum (2005) 'Decentralization and Poverty in Cambodia: Experiences and Challenges'. Regional Development Dialogue, Vol. 26, No. 2, Special Issue.

Sreang, Cheat (2004) 'The Khum from 1897 to 1919 and Its Contemporary Relevance', MA dissertation, Faculty of Social Sciences and Humanities, Phnom Penh, The Royal University of Phnom Penh.

Thion, Serge (1993) Watching Cambodia. Bangkok: White Lotus. 
Turner, Mark (ed.) (1999) Central-Local Relations in Asia-Pacific: Convergence or Divergence? London: Macmillan.

UN (1995) The UN and Cambodia 1991-1995. New York: UN.

UNDP (2002) Lessons Learned in Crises and Post-Conflict Situation: The Role of UNDP in Reintegration and Reconstruction Programmes. New York: UNDP.

Vickery, Michael (1986) Kampuchea: Economics, Politics and Society. London: Pinter/ Rienner.

Woodward, Susan L. (2002) 'Local Governance Approach to Social Reintegration and Economic Recovery in Post-Conflict Societies: The Political Context for Programmes of UNDP/UNCDF Assistance'. Presented at conference on A Local Governance Approach to Post-conflict Recovery, New York, 8 October 2002.

\section{PERSONAL COMMUNICATION AND INTERVIEWS}

Commune Chiefs, Interviews, Battambang and Pursat, October 1999.

MoI, Interview, November 2000, Phnom Penh.

Roome, personal communication, November 1999, Phnom Penh.

Setha, Sak, MoI, interview, Phnom Penh, 30 November 2000.

UNDP Civil Servant, interview, November 1999. 


\title{
Globalization, Women's Political Participation and the Politics of Legitimacy and Reconstruction in Cambodia
}

\author{
Mona Lilja
}

In line with gender roles in many other countries, women's shouldering of economic responsibilities in Cambodia is not reflected in their share of space in the political arena (Lilja 2008). Judy Ledgerwood has suggested that while 'Cambodian women were and are extremely active in economic affairs, it was not considered appropriate for women to be active in politics' (Ledgerwood 1992: 15; Frieson 2001: 6). As a response, the UN-initiated Committee on Elimination of Discrimination Against Women has expressed its concern for the limited participation of women in the public administration as well as in the judiciary (United Nations 2006).

The low number of women within formal decision-making has resulted in protests and various suggestions on how to increase the female share of political positions. Cambodian women themselves do have strategies to change the discourses that construct gender stereotypes, that regulate conduct and form political identities, as well as decide how political power is thought about and distributed (Lilja 2008). Cambodia is a country in rapid transformation with an implemented liberal democracy, a relatively new liberal economy and a high exposure to Western values. In this chapter it is argued that the recent globalization trend and its impact on the reconstruction of Cambodian society in various ways has contributed to making space for the image of 'the woman politician' and the political legitimacy of Cambodian women. In reviewing interviews made with women and male politicians as well as NGO workers, it appears as if globalization enhances the political status of women in at least three different ways. 
First of all, in the globalized era new knowledge is introduced that may be monopolized by women in order to make its status reflect upon the female gender. Secondly, Western-funded NGOs spread new images of possible female political identities in the rural areas of Cambodia. Thirdly, in a globalized world order with plural identities and varieties of discourses, prospects are greater for renegotiating relations of power, while 'old' and 'new' discourses interweave, each influencing the other, thus creating new 'truths'. In this regard, Cambodian women seem to lean upon more Western discourses in order to make legitimate their political power. This is elaborated on in the sections below.

This chapter builds upon 35 interviews made in late 1997, 1999, 2002 and 2007 with politically involved women from three of the main parties: the Front Uni Nationale pour un Cambodge Independent, Neutrale, Pacifique et Cooperatif (FUNCINPEC), the Cambodian People's Party (CPP) and the Sam Rainsy Party (SRP). The selection of the respondents was done through 'snowballing' and includes the whole range of public actors, from members of the Parliament (MPs) and Senate down to grassroots activists. Also some other significant people were interviewed: six additional interviews with male colleagues and eleven with Cambodian NGO workers were made on the issue of women, female leaders, power, resistance and democracy. ${ }^{1}$

\section{GLOBALIZATION IN THE CAMBODIAN CONTEXT}

The process of globalization involves not only the integration of economies and advances in the area of mass media and telecommunications; the interaction between cultural forces creates new lifestyles and identities as cultures converge. Therefore, to many observers, it is within the cultural sphere that globalization will create the most revolutionary changes. A whole range of new patterns of identification has arisen along with the globalization process. First, globalization has lead to the homogenization of identities and experiences, for example the McDonalds-eating and ipod-listening global citizen. Global marketing has thus resulted in a worldwide cultural homogeneity, which in turn 'lead up to the detachment of identity from community and place' (Woodward 1997: 16). However, other identities are also created when contacts, relationships and feelings of closeness develop between different populations. A second effect is that globalization has given rise to paraphrased identities and new weight to 'old' discourses. The insisting global culture then leads to the emergence of new 
national or local identity positions. This identity politics easily becomes a form of resistance performed through the strengthening of local identities (Woodward 1997).

Moreover, according to Kathryn Woodward (1997) the increased migration, which is another impact of globalization, has had a number of effects. One of these effects is the production of plural and contested identities. As people spread across the globe many cities come to offer diversity in culture and identities, and globalization has in this sense lead to a whole range of communities characterized by the existence of competing and conflicting identities (Woodward 1997: 16), a battle embracing inequalities as some identities are given higher rank than others.

Many of the above patterns can be seen in Cambodia, a country to which the concept of globalization is of special importance. Firstly, because the post-war reconstruction of the Cambodian community has been organized on the Western principles of democracy and capitalism, which have in turn transformed the old structures of the society. Secondly, because the massive development assistance contributes to a cultural transformation. According to Ovesen et al. (1996) Western ideas penetrating Cambodia as a result of the aid inflow seem to run counter to a number of elements of the traditional Khmer world view. Popular participation in political decisionmaking processes and relative equality are only two of the ideas promoted by aid programs that are said to contradict the beliefs 'inherent' in the traditional Cambodian culture. A study which covers power structures in rural Cambodia cannot therefore afford to ignore the fact that development planning and the presence of development agents in the country necessarily have an impact on society (Ovesen et al. 1996: 80). In addition to the abovementioned aspects, Cambodia is increasingly experiencing globalization because of the impact of returnees from the extensive migration caused by outbreaks of violence, wars and political instability. There are a growing number of returnees within Cambodian society who have been trained abroad, who have gained a wide experience of Western countries, who hold high office in Cambodia, who regularly travel between continents and who thus more or less have assumed the above-mentioned homogenized McDonalds-eating and ipod-wearing identity. Internationalized as they are, they represent a Westernized thinking and take on secular rules, norms and practices. Within this stratum of Cambodian society, it is generally accepted that women can work within the field of politics. Hence, as elsewhere, globalization in Cambodia has resulted in a more diverse society where 
new, Western values are located side-by-side with and interweaved with more traditional ideas. This division is reflected within the political sphere and among the members of FUNCINPEC and CPP. While FUNCINPEC has recruited many of its members amongst educated exile Khmers, CPP's members often originate from rural areas and are generally less educated.

Cambodia is thus facing the impact of globalization. But is the country gaining from this development? There is much research demonstrating the negative consequences of the spreading of the capitalist market economy to many developing countries. Some of these consequences can be seen in Cambodia, where cheap and unskilled labour is one of the few comparative advantages the government can offer to foreign investors. Most of the 300,000 people in the garment labour force work up to 100 hours a week for approximately 50 dollars per month (Salinger 2006). These conditions are far short of what local labour laws demand. The response has been a new labour movement, in which some of the most prominent leaders have in fact been women. Moreover, other gendered consequences of cultural globalization can also be seen. According to one respondent, another outcome is the new, Western-influenced objectification of women that appears in commercial advertising in today's Cambodia (Interview No 1B). Following the above reasoning, the recent globalization of the Cambodian society can be argued to have made matters worse. However, this process, as is elaborated on below, has an ambivalent appearance, bringing to Cambodia not only human exploitation but also political possibilities, legitimacy and identities for Cambodian women.

\section{'WOMEN' AND POLITICS IN A CAMBODIAN CONTEXT}

[T]he Committee [on Elimination of Discrimination Against Women] expresses concern about the underrepresentation of women at all levels of political and public life, in particular in Parliament, and the low rate of women's participation in elections. The Committee is further concerned about the limited participation of women in the public administration and the judiciary at all levels.

United Nations 2006

To understand the low political participation of Cambodian women, we must unpack the dominant discourses of gender. Ledgerwood describes an image of the ideal Cambodian woman, which many Cambodians relate to in various ways either as a point of reference or as gender symbolism for use in 
political rhetoric (Ledgerwood 1996). She states that the ideal woman is 'shy and must be protected, before marriage ideally never leaving the company of her relatives, she is also industrious' (Ledgerwood 1992: 4). This chimes very well with how Cambodian women were pictured in the interviews. In their 'speakings', many respondents described Cambodian women in general as shy, honest, gentle, active, hard working, humble, economic and unenlightened (Norrlind 1996: 22). One woman stated: 'Women are born more close to their feelings. They are easily sad and scared. Men and women are born different' (Interview No 1C).

This image is also reflected in the Chbap Srey, a poem listing codes of proper ideal gender appropriate behaviour in Cambodia, which among other things emphasizes women's responsibility to obey their husbands ('When you reach the world of human beings, you are to remember that you are only the personal servant of your husband and you should always highly obey your husband') (Derks 1996: 6-7; Ovesen, Trankell and Öjendal 1996: 35-36; Roeun 2004). The rules thus describe women mainly as a subaltern group who are expected to serve, follow and respect their male partners as well as their parents.

The images of men and women, which are presented in the Chbap Srey, seem to reflect the dominating discourses of gender (Lilja 2008). However, the gender imagery has an ambiguous nature and the ideal woman can be both a 'shy, quiet and obedient servant, and a strong, manipulating, vocal village woman' (Ledgerwood 1996: 139-151). In addition, new competing patterns have been introduced that compete with the image of a perfect woman (such as outlined in classic Khmer literature). According to Ledgerwood, the most important image is perhaps the socialist discourse of the strong, hard-working and brave 'revolutionary woman' (Ledgerwood 1996: 139-151). Still, the generally held image of Cambodian women as docile, gentle and subordinated remains and influences the organization of the society (Lilja 2008).

What becomes significant from previous studies, as well as from the interviews, is that while Cambodian women are often described as shy, gentle, uninformed and generally narrow-minded when compared with men, they are assigned a lower status: 'There is still a prevailing belief in the culture that [Cambodian] women are more gentle and submissive than men' (McGrew, Frieson and Chan 2004). This can be illustrated by quoting some of the respondents. For example, one woman said: 'Women in Cambodian society are seen as inferior to men. They are considered mentally weaker. 
This view is stronger in the rural areas than in the towns. Women are not equals. Men see themselves as the intelligent actors' (Interview No 13B). Yet another woman stated: 'Both men and women believe that women are mentally weaker than men' (Interview No 17B). These quotations indicate that a hierarchy has been established which is maintained through discourse. Women seem to play a part in reproducing these discriminating discourses by spreading destructive 'truths' about themselves and their lack of ability. During a group interview the respondents agreed that:

We cannot take full responsibility; we are only women. Women always speak out less than men; men seem to dominate women. We feel afraid to speak out and when we speak out we feel afraid that what we say is wrong because women do not know how to speak. ... Girls are weaker than boys, mentally weaker.

Interview No $1 \mathrm{E}$

This gender hierarchy was also pointed out as one of the contributing causes of the unequal distribution of political power. Several interviews repeated that people in general regard men as the optimum in a public setting, while the ranked and stereotyped image of 'women' fails to correspond to the image of a politician. One male politician said:

One problem is that men do not think that women have any capacity. They think women are morally weak. Women should stay home. Politics is the men's work. ... People in Cambodia don't believe in women. This is especially the case in politics; also in the National Assembly people do not believe in women politicians.

Interview No 14B

One discourse about politics thus defines women as 'non-political' and the political sphere seems to be experienced as a masculine-coded realm. Or in other words, Cambodian women are often stereotyped, given a low rank or simply fail to correspond to the stereotype of a political actor (Lilja 2008). One woman expressed how she experiences low trust in women politicians: '[Some groups of women] want to call themselves women's parties. You destroy your possibilities if you call your party like that ... [if] you call yourself a women party, no one want to join you, and the perception that women cannot be good leaders will remain' (Interview No 2A). This quotation seems to be one representation among others that together constitute a discourse about women's political participation. However, 
this pattern is being increasingly challenged, and gender-roles are under negotiation. In the next sections some suggestions are made about how the globalization and the reconstruction of the Cambodian society, in a postwar era, has opened up to resistance as well as to change (Lilja 2008).

\section{CONNECTING FEMALE GENDER TO HIGH STATUS KNOWLEDGE: GETTING A MONOPOLY OF KNOWLEDGE}

With growing globalization, globalization itself becomes a site for an interpretive struggle, where various parts/characteristics of what is regarded as masculine or feminine are 'co-opted in new or old configurations to serve particular interests, and particular gendered (and other) identities are consolidated and legitimated or downgraded and devalued' (Hooper, in Marchand and Runyan 2000: 60). However, this 'interpretive struggle' over what it means to be a woman or a man involves not only the two genders, but negotiations also occur within these two groups. Different groups of men are positioned in relation to each other as the relationship between masculinity and power is articulated and re-articulated. In this regard, Connell promotes the concepts of hegemonic and subordinated masculinities (Connell 1987: 183-188). To keep its superior position, hegemonic masculinity must change in order not to lose power. For example, in order for professional men to stay ahead in the employment game, more feminine qualities of flexibility, interpersonal skills and teamwork are today occasionally used to reconstitute hegemonic masculinity. What hegemonic masculinity embraces in terms of traits varies over time, but it is always constructed in relation to a range of subordinated masculinities and femininities. Thus, while some woman identities may have higher status than others, all femininities today are subordinated to hegemonic masculinity (Hooper, in Marchand and Runyan 2000: 62). Anita Göransson has developed a similar theory of gender and power in which maleness must be reconstructed in order to correspond to new constructions of power, through for example new organizations and new knowledge, as the world becomes globalized. Thus, men's power is due to the rapidity with which maleness is able to transform itself, and male gender changes faster than femininity (Göransson, in Romlid 1998: 27-31).

From this reasoning there follows the theoretical conclusion that women's resistance to the uneven distribution of power may be applied by redefining femininity faster than masculinity in order to correspond to new fields and 
organizations. By endowing interesting new and important domains with femininity and associating them with the female gender, women may gain new status and political legitimacy.

When reviewing the interviews it became obvious that some Cambodian women politicians use as resistance the fact that globalization has drastically improved the access to advanced technologies. Technology and globalization go hand in hand as the latter unleashes technology and technology helps to make globalization possible. Technology changes how we do the work and organize it, and in nearly all cases the jobs created by it demand more education and training. From this it follows that many computerized jobs/units are carriers of status, especially in a Cambodian context where education and knowledge are highly ranked. This seems to be used by some Cambodian women who admitted to the monopoly of technological knowledge as a factor in facilitating power (Lilja 2008).

Three politically active women at one of the ministries took their afternoon off to talk to me about women and politics. Not only did they reveal their low self-confidence and the obstacles that women experience when they want to become politicians, but they also presented some strategies to gain more status and self-confidence. During the conversation, obtaining access to technological knowledge was presented as a conscious strategy in renegotiating the current location of power. One of the women said: 'I try to teach all women in my department computer skills. They are going to know more than the men. Then the men will have to ask the women to help them. This will increase their self-confidence. Then they will enjoy their work and they will be able to get a better job' (Interview No 5B). This quotation tells us that these women consciously move faster than men to get new skills in the computer-technology in order to position themselves better. Through this strategy women will be in possession of new important knowledge. Men will have to ask women to assist them. Thus, there will be a divide, with men-without-knowledge and women-with-knowledge reversing the hierarchy between the genders (Lilja 2008). Thus, women's new status will be due to the rapidity by which they succeed in adapting to new technological conditions. Femininity is reconstructed to fit the new order and to create a superior role. Those interviewed also revealed that this new hierarchy was transmitting itself to other areas as women gained self-confidence. With the new self-image, a new enjoyment was being achieved and women were, by behaving self-confidently, being able to get important new jobs. Thus, to gain political legitimacy these Cambodian women politicians are 
playing with their femininity and are using the same strategy as hegemonic masculinity, thus redefining it in order to gain more status. This strategy is enabled by the post-war reconstruction of Cambodian society and the fastchanging roles of men and women in a globalized era. How common this strategy is, however, is still to be seen.

\section{'WOVEN DISCOURSES' IN THE LIGHT OF GLOBALIZATION}

As stated above, one discourse about politics in Cambodia defines women as 'non-political' and the political sphere seems to be experienced by many of the respondents as a masculine-coded realm. Politicians also seem to be associated with men and with masculinity. This chapter, however, rests upon the assumption that these kinds of discourses compose 'truths' that may change. As seen above, some women mix the female gender with computer know-how, thus creating a new female identity position by merging the traditional with the new. This kind of 'woven discourse' might be related to the post-colonial concept of hybridity, that is, cultural mixings and crossovers that are powerfully interruptive and that might serve as a tool to understand the resistance of female politicians to the uneven distribution of power (see Werbner 1997: 1). According to Ane Kirkegaard, hybrid/ity/ ization 'denominates a situation in which two or more species, traditions, discourses, social structures etc. are woven into each other forming new species, traditions, discourses, social structures etc.' (Kirkegaard 2004: 26). One way of creating change is thus to weave together different discourses and thereby create a new reasoning. Such processes of transformation are probably growing in significance as we enter a globalized world order where we get access to different 'truths' and possible identity positions (Thörn 2002: 126).

As woven discourses are increasingly made possible by the processes of globalization, it seems as if some female politicians in today's Cambodia tend to use their image of a Western state in order to legitimize their presence in the political sphere. In their view, an ideal form of governance is typified by a caring state. And a caring state could, according to them, be attained by bringing more women into politics, because a female politician, the argument goes, makes a more compassionate and understanding leader than a man. One woman said: '(Women are) capable of sensitizing the whole crowd. Better than men, you know. (...) I think if Cambodia, I'm sure 
... if Cambodia is a democratic country like the Western countries, women would be brilliant in politics' (Interview No 1A).

By emphasizing a Western discourse concerning state formations, the women have tried to authorize and legitimize the idea that they should play a larger role in the political arena. While arguing in favour of women's exceptional democratic qualities, the quotation above draws on the idea of a democracy 'like the Western countries' and puts it together with a discourse about caring, domestic Cambodian women. Hybridity emerges as different discourses merge into a new argumentation for political legitimacy. Also the women leaders mentioned above, who have included in their identity technological know-how, have used a Western discourse to negotiate the identity position of being Cambodian women, creating a hybrid version. These kinds of discourses thus form a sort of capital that one may use to accomplish change, and the conclusion is in line with Ferguson's statement that when 'social spaces are remapped, so are resident identities; prevailing subjectivities' (Ferguson 1993: 177). Or in other words, globalization provides subaltern groups with discourses from abroad that they can employ to renegotiate power sites, in this case the gender equalities within the public administration.

\section{WESTERN-FUNDED NGOS CHALLENGING LOCAL POWER STRUCTURES}

Above, different resistance strategies of Cambodian women were outlined. However, the low status female gender has been negotiated in other ways to increase Cambodian women's political legitimacy. 'The development discourse' prevails as a tool to redefine both prevailing femininities and masculinities.

During the 1990s the discourse of 'development' was increasingly accused of being nothing but a tool for the disciplinary power. From this perspective, this discourse, by defining the developed versus the underdeveloped, has given some countries and institutions the ability to control and in many ways even create the 'Third World', economically, politically and culturally (Escobar, in Braidotti 1994: 21). A. Escobar has identified different strategies, which have greatly extended the power of the development discourse. First of all, more and more issues are defined as development problems, leading to the emergence of new fields of intervention by development experts. These experts increasingly classify and describe the Third World as well as formulate more and more development 
interventions that follow the development logic, that is, the Western economic rationale. In the end, the institutionalization of development on global, national, regional and local level creates a tight network controlling and implementing development policies down to local level (Escobar, in Braidotti 1994: 23). Criticism has thus been put forward by researchers who argue that the West's control over Southern countries has increased with globalization, and as the West's development discourse dominates, local ways, practices and knowledge are increasingly abandoned (Braidotti 1994).

The outline above corresponds to the Cambodian case, where Westernfunded organizations penetrate the rural areas, spreading the message of the Western development discourse. While this pattern can be, and should be, critically discussed, in some cases these organizations also seem to have an empowering effect. Some Western-funded NGOs repeatedly go into rural areas to challenge the traditional view of women as being mentally weaker than men by providing women with a new discourse about womanhood. Some female NGO workers described how they went out to the rural areas not only to present political entrances but also new images of women, reversing the dominating gender roles by representing Cambodian women as smart and actually better leaders than men. One NGO worker, who had recently presented the topic of 'women and politics' to rural women, said: 'Some women in the provinces have the idea that women are mentally weaker than men. Women don't think that women can be leaders. When we tell them that women are smarter than men, they say: Ohhh ...' (Interview No 2B). By introducing a new 'truth', this NGO worker challenged the prevailing discourse and the female identity that regards women as inferior, physically and mentally, to men.

Gender dichotomies and the hierarchies that they nourish seem to be repeatedly transmitted and reaffirmed in the 'speakings' of Cambodian women. Women are then exposed to different power-loaded discourses while at the same time being the ones who forward and maintain these discourses (Lilja 2008). Therefore, in order to upgrade the female identity in general, the subalterns need to revalue their selves. The politicizing of the female identity and women's knowledge is therefore accomplished by 'making visible' their capacity for women themselves. This can help us understand the below quotation where one woman leader explains how women may be encouraged to invest in a political identity. She stated: 'I think the best thing is ... to show them the good points that they already 
have, so they can feel: oh, this is what I do ... and not my husband' (Interview No 8A). Another politically active woman talked about how to include more women in politics: 'We need to probably network for them to be able to provide for themselves first so they can see: OK, this is what I can do, this is what I want to provide for my children, you know ... and so that way they can see a little bit higher' (Interview No 8A).

Western-funded NGOs, by presenting a new interpretation of female identity, provide the women - the listeners and receivers of discriminating discourses - with a possibility to resist what Hall calls 'preferred meanings'. Producers of meaning construct 'truths' or images that they expect to match generally known discourses. The message conveyed is therefore often comprehended in the way s/he hopes, and the majority will read the message in a very similar way to the preferred meaning. However, there will always be those who resist the preferred meaning and interpret the message differently because of their own knowledge, that is, their experiences in terms of contact with other discourses or positions as subjects (status, identity, etc.). For example, androcentric meanings concerning politics and politicians may be read differently from a feminist discourse. Making visible new 'truths' and meanings may thus, as exemplified above, have the impact of opening up a space for other interpretations than the preferred meaning (Skelton 2000: 182). This seems to be the case in the rural areas of Cambodia, where a new discourse about women's political possibilities and legitimacy is added to the traditional ones in a time of reconstruction.

According to some female NGO workers many women found the possibility of political participation tempting and declared themselves to be interested. The institutionalization of development mentioned above by A. Escobar and the implementing of Western development policies down to local level might then contribute to the emancipation of Cambodian women, as they may negotiate hierarchies as well as provide women with the possibility to exercise decision-making power. Women may gain new legitimacy as politicians and they may actually choose to become politicians. This mirrors Foucault's 'refusal of becoming' - maybe the target nowadays is not to discover what we are, but to refuse what we are (Foucault in Dreyfus and Rabinow 1982: 212)? However, is it possible for women politicians to refuse being hailed into place, to perform the dominant image of a woman? Butler argues that the disciplinary apparatus, and its connected identities, becomes an 'abiding object of passionate attachment', and states that such a postulation may raise the question of masochism: 
Certainly, we cannot simply throw off the identities we have become, and Foucault's call to "refuse" the identities we have become will certainly be met with resistance ... how are we to understand not merely the disciplinary production of the subject, but the disciplinary cultivation of an attachment to subjection?'

Butler 1995: 243-244).

Thus, whether or not the work of the NGOs will have a lasting impact needs to be further researched.

\section{CONCLUSION}

Globalization has contributed to women's political legitimacy and possibilities and to making a space for a female political identity in at least three senses. The first strategy of resistance used by female politicians is to give women the monopoly of specific technological knowledge, made possible by globalization, thus in some senses negotiating the hierarchy between the sexes. Secondly, one may speculate that discourses are being more easily transformed now with growing globalization. When new globalized 'truths' are introduced in a Cambodian context, the established as well as the growing discourses are transformed. This is used by women politicians, who draw on 'Western' discourses about the caring politician to increase their legitimacy. A third strategy involves bringing more women into politics by introducing new images of female identification and thereby challenging old established 'truths' about 'who is a politician'.

\section{REFERENCES}

Braidotti, Rosi (1994) Nomadic Subjects: Embodiment and Sexual Difference in Contemporary Feminist Theory. New York: Columbia University Press.

Butler, Judith (1995) 'Subjection, Resistance, Resignification'. In John Rajchman (ed.), The Identity in Question. New York: Routledge.

Connell, Robert, W. (1987) Gender and Power: Society, the Person and Sexual Politics. Stanford: Stanford University Press.

Dreyfus, Hubert L. and Paul Rabinow (1982) Michel Foucault: Beyond Structuralism and Hermeneutics. Brighton: Harvester Press.

Ferguson, Kathy (1993) The Man Question: Visions of Subjectivity in Feminist Theory. Berkeley: University of California Press.

Frieson, Kate (2001) In the Shadow: Women, Power and Politics in Cambodia. Centre for Asian-Pacific Initiatives, Victoria, Occasional Paper 26. 
Kirkegaard, Ane (2004) A Matter of Difference? Family Planning and Gendered Discourses on Sexuality and Reproductive Decision-making among Black and White Zimbabweans. Department of Peace and Development Research, Göteborg: Göteborg University.

Ledgerwood, Judy (1992) 'Analysis of the Situation of Women in Cambodia'. Paper, Phnom Penh.

Lilja, Mona (2008) Power, Resistance and Women Politicians in Cambodia: Discourses of Emancipation. Copenhagen: NIAS Press.

Hooper, Charlotte (2000) 'Masculinities in Transition'. In Marianne H. Marchand and Anne Sisson Runyan (eds), Gender and Global Restructuring: Sightings, Sites and Resistances. London: Routledge.

Ovesen, Jan; Ing-Britt Trankell and Joakim Öjendal (1996) When Every Household is an Island - Social Organizations and Power Structures in Rural Cambodia. Uppsala: Research Reports in Cultural Anthropology.

Romlid, Cristina (1998) Makt, Motstånd och Förändring: Vårdens historia speglad genom det svenska barnmorskeväsendet 1663-1908 [Power, Resistance and Change: the history of Swedish health care reflected through the official midwife system 16631908]. Stockholm: Vårdförbundet.

Salinger, Lynn (2006) 'Cambodia Garment Industry Workforce Assessment: Identifying Skill Needs and Sources of Supply'. Phnom Penh: Publication produced by Nathan Associates Inc. for the United States Agency for International Development.

Thörn, Håkan (2002) Globaliseringens Dimensioner: Nationalstat, Världssamhälle, Demokrati och Sociala Rörelser. Stockholm: Atlas.

United Nations (2006) Women's Anti-discrimination Committee Considers Cambodia's Report', January 19.

United Nations General Assembly (2006) WOM/1530, Department of Public Information, New York. Committee on Elimination of Discrimination against Women, 705th \& 706th Meetings AM \& PM 19 January.

Werbner, Pnina (1997) 'Introduction: The Dialectics of Cultural Hybridity'. In Pnina Werbner and Tariq Modood (eds), Debating Cultural Hybridity: Multi-Cultural Identities and the Politics of Anti-Racism. London: Zed.

Woodward, Kathryn (1997) 'Concepts of Identity and Difference'. In Kathryn Woodward (ed.), Identity and Difference. London: Sage.

\section{INTERVIEWS ${ }^{1}$}

Interview No $1 \mathrm{~A}$

Interview No 1B

Interview No $1 \mathrm{C}$

Interview No $1 \mathrm{E}$

Interview No $2 \mathrm{~A}$ 
Interview No 2B

Interview No 5B

Interview No 8A

Interview No $13 \mathrm{~B}$

Interview No 14B

Interview No 17B

\section{NOTE}

1 I have taken measures to protect my respondents. First and foremost, the names of the respondents will remain secret. The interviews made in June-July 1997 are labelled B, those made in May-June 1999 labelled A, those from July-August 1995 labelled C, those from July 2002 labelled E and those from April-May and June-July 2007 labelled F. In addition, all interviews are given numbers. Exposing the names of the female politicians could mean to jeopardise these women's positions, as they are highly depended upon the goodwill of the political parties. 


\section{Chapter 6}

\section{The Political Economy of Aid and Regime Legitimacy in Cambodia}

\section{Sophal Ear}

It has been said that economics is the study of choice, while sociology is the study of the absence of choice. In many ways, the post-conflict reconstruction of Cambodia is a case study in the absence of choice on whether or not to engage donors and, in a wider sense, on how to relate to the overall global political economy. The country was a 'pariah state' for the duration of the 1980s, but thereafter sought to establish normal international relations and acceptance. In the aftermath of the Cold War, the Paris Peace Agreement signed on 23 October 1991 signalled the cessation of open warfare, though not the end of conflict itself for Cambodia. Politics is, some would say, war by other means.

In the early 1990s, Cambodia was in an economic tailspin. Having lost most of its Soviet Bloc aid, triple-digit inflation hit the country in 1990-93. It had an unsustainable budget deficit ${ }^{1}$ and desperately needed international donor support to prop up its economy. The country had few alternatives in this early post-conflict phase (1993-98) but to engage with donors in order to build political legitimacy ${ }^{2}$ through a so-called democratic process. It was also at about this time that, with the triumph of capitalism over communism and against the background of the Latin American debt crisis of the 1980s, a 'Washington Consensus' emerged (Williamson 1990), one that would become neatly prescribed for Cambodia's transition from a planned to a market economy (Ear 1997). Washington pursued a predetermined economic programme of a technocratic nature, and Cambodia was only too happy to embrace its policies, implementing them selectively based on the prevailing political-economic conditions. Over time, Phnom Penh 
grew dependent on large annual infusions of aid with increasing strings attached.

Unfortunately for Cambodia, the country was an early test-case for postconflict reconstruction, and the World Bank had at the time little experience with genocide-afflicted, civil-war-torn countries. ${ }^{3}$ The Bank's Post-Conflict Fund was established only in 1997, four years after the United Nations Transitional Authority in Cambodia (UNTAC) had administered elections, and only because of two unrelated major events: the establishment of the Holst Fund for the West Bank and Gaza in 1994, and the Bank's leadership role with Europe in post-conflict recovery in Bosnia and Herzegovina in 1995 (World Bank 2004c). ${ }^{4}$ In a cynical remark reflecting a general view on the late start, an NGO commentator pointedly remarked, 'so the Bank has discovered peace' (World Bank 2004c: 5). And while donors like the Bank now realize the importance of a 'broader approach to good governance' (ibid.) in post-conflict situations, their approach to aid too often leaves countries dependent and lacking political legitimacy. The Asian Development Bank first defined governance as 'sound development management' (ADB 1995: 8) in 1995, while the United Nations Development Programme delved into 'Democratic Governance' (UNDP 1997) in 1997, three years after the US Agency for International Development (USAID) created a Center for Democracy and Governance in May 1994.

Cambodia was on its way to becoming a failed state by the late $1980 \mathrm{~s} .{ }^{5}$ In the early 1990s, the country faced a dilemma of how to reconstruct its state and society. Post-conflict reconstruction requires the re-establishment of political stability and regime legitimacy. Beyond this, it also involves establishing effective state capacity, ${ }^{6}$ which is a broader concept than political stability and regime legitimacy alone. Reducing state capacity implies an undermining of state legitimacy, encouraging, in turn, a culture of tax evasion that generates further deficits that must be covered by increased borrowing (Badillo et al. 2001: 18). State capacity also implies respect for the rule of law, control of corruption, voice and accountability, and other dimensions of governance. ${ }^{7}$ Likewise, political legitimacy is a multi-faceted concept including the rule of law, working institutions and popular consent. Indeed, seen from this perspective, the question of what quality of governance has been achieved in the last decade with donor support is paramount. ${ }^{8}$ Moreover, explicitly linking quality of governance with development outcomes in the last decade is crucial to understanding the political economy of aid and the attempt at building regime legitimacy in 
Cambodia. Thus, this chapter operationalizes political legitimacy in terms of state capacity (as implied by tax revenue collection) and dimensions of governance - such as corruption - through the lens of development outcomes (infant and child mortality, poverty, inequality, etc.).

This chapter has the following structure. ${ }^{9}$ I discuss the political economy context of the last decade of aid, development and corruption. I intend to give the reader an appreciation of the conditions faced by Cambodia in the 1990s when the country began to re-establish its political legitimacy. I explain the challenges to establishing political legitimacy in light of high aid dependence and 'Dutch disease' in the aid sector. ${ }^{10} \mathrm{I}$ end with an examination of development outcomes where, despite large aid infusions, infant and child mortality and inequality have risen, ${ }^{11}$ and control of corruption has seen precious little progress. Then I delve into how the authorities have coped with aid dependence and embraced 'normalcy'. I argue that, at some level, they have succeeded in transforming the country's normalization of international relations and aid into external and internal political legitimacy, respectively. I then discuss continuity and change in the authorities' public perceptions of donors and how this has played out in terms of reform and corruption.

Then I offer two case studies, the first is an opportune natural experiment in how a political crisis turned into an economic crisis, namely the budgetary crisis caused by the 'events of 5-6 July 1997'. ${ }^{12}$ The case suggests that external pressure to force reform, while initially successful at increasing domestic revenue collection, has since floundered. The second case study, on Cambodia's long struggle with donors over logging between 1995 and 2005, suggests that while authorities may cooperate in the shortto-medium term with donors to increase external political legitimacy, in the absence of political will, original patterns re-emerge. Both cases taught the authorities to find alternative sources of revenues to diversify the country's donor portfolio. And indeed, Cambodia has since tapped nontraditional donors like China, South Korea and Pakistan, who exercise less explicit interference in the country's internal political affairs (read human rights and democracy). Finally I summarize the chapter's main findings, underscoring the challenges to enhancing political legitimacy and governance in a post-conflict, aid-dependent environment. 


\section{THE POLITICAL ECONOMY CONTEXT: A DECADE OF AID, DEVELOPMENT AND CORRUPTION}

The impact of the Khmer Rouge period and its aftermath was overwhelming: massive loss of human resources from death, disease and displacement. ${ }^{13}$ Cambodia's structural weakness in the early post-conflict period, both macroeconomic and in terms of state capacity, left the country with few if any choices in dealing with donors and vice-versa. As is the case in most less developed economies, statistics on the economy at the time were at best unreliable, if available at all. ${ }^{14}$ There arose as well a credibility gap as aid dependence and a particular version of the 'Dutch disease' set in. The authorities chose to dissuade donor fears by immediately adopting their language, that is, the language of the aid industry, even though it was not always as keen to deliver on the promises. Unfortunately, the outcome of a decade's worth of post-conflict reconstruction and development suggests that the political economy bargain that was struck resulted in increased infant and child mortality relative to 1990 and increased inequality and corruption relative to the early to mid-1990s.

\section{Setting the Economic Context in the Late 1980s-90s}

Two major economic factors were at play by the time UNTAC arrived. First, the loss of aid from former Soviet Bloc countries ${ }^{15}$ severely affected public sector finances, and caused macroeconomic imbalance - an estimated budget deficit of nearly 4.6 per cent of GDP in 1992 (World Bank 1994). ${ }^{16}$ Aid dropped 35 per cent from 1987 to 1988, while trade as a percentage of GDP stagnated between 1989 and 1990. Second, subsequently extremely high inflation and exchange rate instability emerged, where e.g. retail price inflation exceeded 100 per cent for much of the early 1990s.

In 1989, when the Vietnamese army began to leave Cambodia, aid doubled, and in 1991 it tripled. ${ }^{17}$ It was in that year that the UN SecretaryGeneral Javier Perez de Cuellar appealed to the International Community to support Cambodia's rehabilitation efforts following the signing of the Paris Peace Accords in October 1991. This resulted in pledges and other commitments totaling US\$880 million at the first International Conference on the Rehabilitation of Cambodia (ICORC) in Tokyo in June 1992. New pledges of US\$119 million were added in September 1993 in Paris. In 1994 the total amount of aid committed to Cambodia at the second ICORC in Tokyo again garnered over US\$800 million through $1996 .{ }^{18}$ For several 
years now the Royal Government of Cambodia (RGC) has relied on aid for about half of its budget. Domestic revenues, however, have not kept pace with expenditures, in reality cementing the RGC's dependence on foreign aid. ${ }^{19}$

\section{Aid Dependence: 'Dutch Disease' and Fungibility}

From 1995 to 2003, US\$4,263,000,000 of external financial assistance was disbursed to Cambodia ${ }^{20}$ averaging 13 per cent of GDP annually. That average exceeded domestic revenue collection for the entire nation (c.12 per cent), and while this aid was intended to help develop the country, its massive infusion also served to distort an economy with limited absorptive capacity. While it was desperately needed for reconstruction, it became apparent by the turn of the millennium that aid had had unintended and undesired consequences. Two specific problems were apparent:

The scale of aid is such that it distorts the economy. In an aid-related version of 'Dutch disease', a high proportion of Cambodia's scarcest resource, educated people, is pulled toward employment in donor agencies and international non-governmental organizations or attached to projects as salary-supplemented counterparts. At the same time, donors and NGOs virtually take over the funding of education, health care, social welfare, rural development etc., while government spends most of its funds on defense and security.

Godfrey et al. 2000: 123http://www.colmex.mx/centros/ceaa/sitioceaa/ imagenessitioceaa/imagenespaginamarston/ap01a.htm - _ftn37

The 'Dutch disease' effect is particularly pernicious. In the case of Cambodia, aid crowds out other sectors, becoming a tradable sector financed by 'revenues' in the form of aid. Donor-financed workshops and conferences abound, civil servants are often abroad on 'study tours', and even have their salaries supplemented.

It should be said that civil servant salaries are barely above the national poverty line of 45 cents per day per person, ${ }^{21}$ making moonlighting or gravitation towards the aid sector almost a necessity. Yet civil service reform is not a high priority for the RGC for political economy and patronage reasons, ${ }^{22}$ enabling the abuse of public office for private gain. Salaries - still in the US\$20-US\$40 per month range - have increased, but have not kept up with inflation. The Soviets used to joke, 'They pretend to pay us and we pretend to work.' The same can be said of civil servants in Cambodia. 
The second problem described by Godfrey et al. (2000) in which aid allows government not to spend on basic services, without using its moniker, is that of aid 'fungibility'. ${ }^{23}$ By 2005, the analysis remained the same. A development expert with a dozen years' experience in Cambodia complained that 'In some ways, donor projects have stifled government initiative, placing foreign agencies largely in charge of the government's service provision responsibilities' (Informant O, 7 May 2005). Another expatriate with five years' experience in NGOs added that 'In some ways NGOs can't avoid working with the government. In some ways they should' (Informant M, 3 May 2005). Indeed, the failures of development detailed below, including the outsize compensation of foreign advisors relative to their government counterparts, have made aid inescapable for Cambodia and indispensable for the aid industry.

What the aid variant of the 'Dutch disease' implies for Cambodia is the functional equivalent of brain drain into the aid sector from both the government and the private sector, the latter widely acknowledged as the engine of growth in any country. State capacity is weakened as a result, as is, by extension, regime legitimacy, when the best and brightest are neither entrepreneurs nor government policy wonks. Working for donors, they will naturally be donor-driven, and while the goal of aid may be development, for bilateral aid it is more often than not the donor country's foreign policy and national interest that take precedent. ${ }^{24}$ In Cambodia, aid spent by donors on 700 international consultants in 2002 was estimated to total between US\$50 and US\$70 million, approximately equal to the wage bill for the country's 160,000 civil servants (ActionAid 2005: 22). Donor-financed consultants working in the RGC are paid upwards of 228 times what their Cambodian counterparts receive. ${ }^{25}$

Having established that aid may distort the Cambodian economy by siphoning talent from government and the private sector, it is apparent that the country's tenuous balance between aid and political legitimacy needs to be rewritten. Clearly, there is an urgent need to focus aid on political legitimacy by improving governance. As both the Prime Minister and the Finance Minister have said on separate occasions in 2001, '[The RGC is] conscious that good governance is a sine qua non condition for promoting social and economic development and sustainable social equity' (Hun 2001b; Keat 2001). ${ }^{26}$ Deputy Prime Minister Sok An followed up with 'There is no need to plead the case of good governance. We are all converts. ${ }^{27}$ Yet, if 
pleading the case of good governance is to preach to the converted, actions (and political will) still speak louder than words. What progress to date?

\section{Development Outcomes: Infant and Child Mortality, Poverty, Inequality and Corruption}

A decade of Cambodian development has proved that technical solutions often fail in the face of political reality. Notwithstanding large annual infusions of aid, what is known of development in Cambodia is this: infant and child mortality, as reported by the World Bank, have risen since 1990 despite real GDP growth of c.7 per cent per year in the last decade. ${ }^{28}$

In 1990, 80 infants out of 1,000 died in their first year. By 2001, that number had increased to nearly 97 in 1,000. While a jump over the course of a decade may be an anomaly, what gives confidence in this trend is the continuous rise for the years in between: 1992, 1995, 1997 and 2000. Moreover, child mortality (under 5) also rose steadily from 115 per 1,000 in 1990 to 120 in 1995, 135 in 2000, 140 in 2001. Together, infant and child mortality rates are the highest in the region, higher than even TimorLeste which in 2003 had an infant mortality of 87 in 1,000 and a child mortality rate of 124 in 1,000 (the equivalent of 1995 Cambodia) (World Bank 2005b). ${ }^{29}$

With respect to poverty reduction from 1994 to 2004, indications were that little or no progress had been made by early 2005 . This changed by late 2005 and early 2006 when the World Bank (2006a) announced a significant 12 percentage point decrease in poverty over the last decade based on household consumption data collected in 2004. The Bank recalculated the national poverty rate in 1993/94 from 39 per cent (Prescott and Pradhan 1997; World Bank 1999) to 47 per cent using backward projection. Thus, instead of announcing that poverty had decreased very modestly from 39 per cent to 35 per cent in 1993-2004, the Bank announced that poverty had decreased from 47 per cent to 35 per cent. In 1993/94, only 56 per cent of Cambodian villages and only 65 per cent of rural areas were accessible. The backward projection assumes that the remainder of the country, largely controlled by the Khmer Rouge (by then known formally as the Democratic Party of Kampuchea or DPK), was much poorer than its nonDPK counterpart. ${ }^{30}$

However, contrary to the Bank's assumption that the DPK areas were poorer than the non-DPK areas, it is generally known that the DPK areas were thinly populated and had significant natural resources, including abundant 
fish, forests, and gem mines (especially in Pailin). The close proximity of some DPK areas to Thailand also enabled unofficial trade. According to notes taken during UNTAC senior staff meetings on 27-28 April 1992, UNTAC's impression of DPK zones was that they were 'prosperous' (quoted in Heder 2006). ${ }^{31}$

Moreover, sensitivity analysis reveals the lack of robustness in the World Bank (2006a) findings. If the 2004 national poverty line (1,826 Riels or US $\$ 0.45$ per person per day) is increased by only 10 per cent, or 183 Riels (US\$0.045), the national poverty rate jumps to 41.6 per cent from 35 per cent. This 6.1 percentage point difference represents a 17.4 per cent increase in poverty. Caution should thus be exercised in interpreting the gains made in reducing poverty in 1994-2004. More worrisomely, inequality was found to have increased significantly. In non-DPK parts of Cambodia that were surveyed in 1993/94, the Gini coefficient for real per capita consumption was 0.35 . This increased to 0.40 in 2004. The Gini coefficient for all of Cambodia was 0.42 in 2004, making the country one of the most unequal in the region.

Worsening inequality has taken place in the nearly complete absence of control of corruption as a major impediment to development in Cambodia. To combat corruption, Cambodia has floated a draft law on corruption since 1994. However nothing has yet passed the National Assembly. A 2004 survey of corruption shows that unofficial payments ${ }^{32}$ amount to 5.2 per cent of surveyed firms' gross revenues (World Bank 2004b), more than twice that of Bangladesh, Transparency International's bottom performer on the Corruption Perception Index (CPI) 2004..$^{33}$ Cambodia was ranked for the first time in the $2005 \mathrm{CPI}$ at 130 out of $158 .{ }^{34}$ Corruption has been estimated at US\$120 million per year (World Bank 2004b) and between US\$300-500 million per year by Calavan et al. (2004) for USAID. This latter figure suggests that up to 12.5 per cent of Cambodia's c.US $\$ 5$ billion GDP is possibly consumed by corruption.

A foreign expatriate who first worked in Cambodia in 1990 remarked that the 'Situation has deteriorated [since then]' (Informant C, 3 May 2005) while a Cambodian expatriate with a decade's experience said that the 'anti-corruption bill is a joke' (Informant J, 3 May 2005). One Cambodian expatriate with seven years' experience in management at an International NGO called on more 'international pressure' (Informant L, 3 May 2005) and a foreign expatriate with five years' experience in development went so far as to suggest that donors 'May have made corruption worse' (Informant 
D, 3 May 2005). In February 2005, James Wolfensohn, then President of the World Bank, announced:

Fighting corruption, fighting corruption, fighting corruption ... This is Cambodia's problem. If you do not move, no one will cry over Cambodia ... If you do not become a credible competitor, it will be because of Cambodians, not because of the international community.

Reuters 2005

Cambodia's decade of development following UNTAC suggests that while the overall macro-economic picture appears healthy, with moderate growth of around 7 per cent per year, there are troubling signs of sagging human development, rising inequality and corruption. Commingled with the effects of aid dependence and 'Dutch disease' on state capacity and governance, this has placed at risk the country's fragile journey towards political legitimacy.

\section{COPING WITH AID DEPENDENCE AND EMBRACING 'NORMALCY'}

Cambodia has attempted to cope with aid dependence by using it to adroitly acquire a veneer of regime legitimacy both internally and externally. This section examines two aspects of Cambodia's handling of external financial flows and the normalization of international relations. These aspects were chosen because they reveal different facets of the aid-cum-regime legitimacy maze, and because more was known about these aspects through public pronouncements by the authorities concerning views held at specific points in time. By extension, their evolution over time becomes apparent.

As will be detailed, the authorities attempted to transform aid into internal political legitimacy in two ways. First, until 1996, the authorities viewed donors' pledges of 'unconditional aid' as a vote of confidence in the country, which the authorities interpreted as confidence in their leadership. Second, beginning in 1999 and in light of mounting conditionalities, the authorities took as a vote of confidence annual donor pledges that exceeded the authorities' request for aid. Indeed this has been true for the 1999, 2000, 2001, 2002 and 2006 Consultative Group (CG) meetings held. The regime's continuity and change in its view of donors is also notable and examined separately. At various moments it has embraced monitoring and constructive criticism and yet has lashed out at the diplomatic corps when the latter criticized the RGC. 
As will be apparent, large and generous infusions of aid have enabled the authorities to not improve domestic revenue collection, particularly an effective tax collection system (since aid is fungible), which in turn has led to weak state capacity in the post-conflict period, and instead allowed a patronage system of informal revenue collection to blossom in which authorities do not need 'people', just loyalty in the chain of hierarchy.

\section{Transforming Aid and Normalcy Into Internal and External Political Legitimacy}

The RGC's view of donors has evolved over the years from an asymmetric relationship where Cambodia was at the mercy of donors in the early postconflict reconstruction phase to one of 'Development Partners'. ${ }^{35}$ A 1997 press release by the Royal Embassy of Cambodia in Washington, DC, announced proudly, 'Donors Continue Unconditional Aid to Cambodia' (REC 1997). Then First Prime Minister Norodom Ranariddh, on behalf of the RGC, underscored that the aid pledges reflected 'the support and confidence of the donors to the RGC's Public Investment Program' (quoted in REC 1997).

Later, when the conditionalities became unavoidable (or rather undeniable), the authorities claimed that if donors met or exceeded the RGC's request at annual CG meetings, this was 'clearly a vote of confidence in Cambodia'. In 2002, Hun Sen announced that:

The Royal Government submitted a request [at the 2002 CG] for only about US $\$ 430$ million, yet the international community pledged more than US $\$ 600$ million in assistance - excluding the US\$50 million pledged by NGOs! The increased level of assistance is clearly a vote of confidence in Cambodia ... In this sense, the success of the CG signifies the approval of the appropriateness and success of the government reform policies implemented so far ... We, the Cambodian people, have reclaimed our destiny and become a genuine participant and partner in regional and global affairs. Our national unity has strengthened, and we are well and truly on the way toward our destiny as a free, independent nation, blessed with the fruits of sustainable socio-economic growth.

Hun 2002

Certainly, how else could receiving more than what was asked be perceived? In what appears to be an annual exercise in cognitive dissonance, donors have scolded the RGC during the CG, ${ }^{36}$ only to turn around and give more than the RGC asked (see Table 6:1). 
Table 6:1: Royal Government of Cambodia Aid Requests, Donor Pledges and Disbursements

\begin{tabular}{|c|c|c|c|c|c|c|c|c|c|}
\hline $\begin{array}{l}\text { Consultative } \\
\text { Group Meeting }\end{array}$ & 1996 & 1997 & 1998 & 1999 & 2000 & 2001 & 2002 & 2003 & 2004 \\
\hline $\begin{array}{l}\text { (1) RGC } \\
\text { Requested } \\
\text { Next Year }\end{array}$ & $500^{*}$ & 449 & N/A & 450 & 500 & 500 & $480^{\wedge}$ & N/A & 500 \\
\hline $\begin{array}{l}\text { (2) Donors } \\
\text { Pledged } \\
\text { Next Year }\end{array}$ & $500 \#$ & 450 & N/A & 470 & 548 & 556 & $635^{* * *}$ & N/A & 504 \\
\hline $\begin{array}{l}\text { (3) Disbursed in } \\
\text { Preceding Year }\end{array}$ & 513 & 518 & 383 & 433 & 400 & 467 & 472 & 531 & 546 \\
\hline $\begin{array}{l}\text { Location of } \\
\text { Meeting }\end{array}$ & Tokyo & Paris & N/A & Tokyo & Paris & Tokyo & PP & N/A & PP \\
\hline
\end{tabular}

* Upper range was US\$550 million, based on US\$1.6 billion for three years.

*** Revised to US\$514 million after redefinition of aid

\# UPI (1996) reported US\$518 million

$\wedge$ DPA (2002) reported US\$485 million.

Does not include data for 1998, 2003, and 2005 when the CG Meeting was not held and therefore no pledges were made. The 2006 CG was rescheduled from December 2005. As reported in AP (2006), the 2006 CG saw US $\$ 601$ million pledged against US $\$ 513$ million requested by the RGC. No disbursement values for 2005 were available.

Source: (1) various news sources; (2) and (3) RGC (2004).

One should keep in mind that commitments differ from actual disbursements. ${ }^{37}$ And almost always, starting in 1999, disbursements were below commitments because donors simply had double counted or miscounted or reneged, but not because of poor performance by the RGC (at least it was never said publicly). This is a source of anxiety each year on the part of the RGC since this discrepancy is sometimes exploited by critics as evidence of corruption.

Because money (including aid) is fungible, it has expanded the feasible set of instruments that can be used by the authorities to increase internal legitimacy by allowing resources to be spent in unofficial ways. This has allowed the authorities to increase their own powerbase, but moreover large-scale patronage has also enabled the state: (a) not to reform; (b) not to increase domestic revenue collection through the establishment of an effective tax collection system; (c) not to seek popular support (but instead build chains of patronage); (d) not to decentralize and deconcentrate power (but instead to consolidate it under the trappings of a 'Decentralization and Deconcentration Program'). In other words, it is a part of the explanation of 
why internal legitimacy (as earlier elaborated) has not been built to a very high degree.

According to a foreign adviser, the largest source of private funding for education in Cambodia originates from the Prime Minister himself (Informant K, 2 February 2006). While no precise figures are available, innumerable schools bear his name, a number of which are known to sit empty because teachers are unwilling or unable to remain in rural areas under difficult conditions while they are paid low wages. With the help of China, the authorities have projected regime legitimacy by building large government edifices, for example the Senate buildings constructed following the 1998 election and the amendment to the Constitution that called for the creation of that institution and a recently announced new Council of Ministers building at a cost of US $\$ 30$ million, again courtesy of China (on which more is detailed in the section 'Case Studies' below, including South Korea and Pakistan) (Shaw and Pin 2005).

The authorities' desire for external political legitimacy manifests itself through a hunger for recognition and acceptance ${ }^{38}$ on the international stage. Having been denied such recognition as a 'pariah state' throughout the 1980s, ${ }^{39}$ after Vietnam invaded and occupied Cambodia in 1979, it was in the post-1993 period that Cambodia was fully embraced internationally, enjoying 'normal' relations with the rest of the world and international organizations. As a Cambodian governance expert who works for a donor agency surmised, because of this authorities have deep-seated abandonment issues (Informant B, 13 February 2006). ${ }^{40}$ UNTAC enabled Cambodia's return to the international stage by neutralizing the conflict and introducing the mechanics of a multi-party democracy.

In 1999, Cambodia acceded to the Association of Southeast Asian Nations (ASEAN), which also meant joining the ASEAN Free Trade Area when the latter comes into effect in 2015. It was also at about this time that Cambodia began preparations for accession to the World Trade Organization, which it formally joined in 2004 after a nearly year-long delay in forming a government following national elections in 2003. Since 2004, the country has aimed for a non-permanent seat on the United Nations Security Council, arguing that its time had come. It has rallied some regional support for its candidacy. Cambodia is sending military officers to a UN peacekeeping force in Sudan, just a decade after having hosted what was then the biggest UN peacekeeping operation ever (Vatikiotis 2005). 
As one senior diplomat put it, 'Cambodia is slowly graduating to being a normal country' (Informant I, 24 February 2006).

The normalization of Cambodia's international relations following UNTAC has significantly raised its external political legitimacy. Overall, it would also appear that the authorities have generally been successful in obtaining the trappings of internal legitimacy with the help of aid, but whether this legitimacy can be more than skin-deep will depend on the depth of badly needed reforms in governance, few signs of which are apparent. In other words, the projection of regime legitimacy is stronger externally than it is internally. Marc Tarabella, first vice-chairman of the European Parliament committee for ASEAN relations and leader of a six-member EU delegation that came in April 2006 to evaluate human-rights conditions, said at a press conference before the delegation's departure: 'Stability is needed and stability has been achieved ... For example, the election in 2003 was judged by all as held in excellent conditions ... Elections, they don't happen in every country in the world. Here, the opposition can criticize' (quoted in Kvasager and Pin 2006). Indeed, donors have a strong incentive to recognize Cambodia as a stable and democratically progressing country while the reality may differ markedly from the point of view of citizens or longer-term observers of the country.

\section{Continuity and Change in the RGC's View of Donors}

While one man cannot alone transform a regime, Hun Sen has held power as Prime Minister since 1985. In 1993 he turned an electoral loss into a gain when His Majesty Norodom Sihanouk declared that there would be 'no winners and no losers' following the elections, giving birth that year to a government with two Prime Ministers. This gave his Ministers a modicum of the political legitimacy that they had so long coveted. This is true despite the plurality of votes won by the royalist FUNCINPEC party that same year. Hun Sen has spoken at length about Cambodia's relationship with donors. He commented in 1999 on the subject of donor interference and Cambodian transparency and accountability as follows:

[The] RGC does not regard the monitoring of the implementation of the reform programs, constructive criticisms, suggestions and recommendations provided by donors as interference in our internal affairs or conditionalities. We welcome any well-thought suggestions and consider them as common concerns by one partner in development for the difficulties, welfare and progress of another partner. All reform measures designed 
and currently implemented by us are Cambodia's own needs. Therefore, these are Cambodia's own matters. [R] eforms are a life-and-death problem for Cambodia ... Our proposed reform programs and the improvement actions scrupulously implemented by us are not to please anyone. They are Cambodia's overriding needs and are designed to benefit Cambodians from all walks of live. We welcome and accept all these suggestions and recommendations, for they respond to our needs for reforms. Moreover, as an aid recipient country Cambodia should assure donors about its transparency and accountability. In this sense, donors should be able to make their own assessment whether the recipient is merited to receive the assistance. Therefore, donor's monitoring of the implementation of the government's reform programs is an important part of this process.

Hun 1999

While the authorities accepted a new measure of responsibility for the country's own development, little if anything happened during this time to change the way things actually worked in Cambodia. Donors returned to a status quo of continued indulgence while the RGC forestalled reforms. The RGC's rhetoric reached a fevered pitch in March 2001, when Hun Sen declared:

In this sense, as I stated on many occasions, reform is the 'life-or-death' issue for Cambodia. The goals, policies and programs are not to please anyone in Cambodia or outside or to gain temporary reprieve from criticism. They are truly nationally owned and accepted because we believe in them and we wish to adhere to them for the benefits of Cambodians today and to be born. Therefore, if we fail we cannot blame anyone but ourselves.

Hun 2001c

By August 2001, the RGC's tune had changed sharply. At a conference on 'Building a Coalition for Transparency' co-organized by the Asian Development Bank and the Center for Social Development (a nongovernmental organization), Hun Sen and members of the RGC acknowledged the presence of corruption in their administration but suggested that it would be best confronted by donors giving more money to combat it. ${ }^{41}$ At the same conference, the then US Ambassador to Phnom Penh, Kent Wiedemann, and other diplomats invited to speak responded that the RGC's request for technical assistance and more time to draft corruption laws was inappropriate. ${ }^{42}$ In a prelude to a speech by the then Singapore Ambassador to Phnom Penh, Verghese Mathews, in which the latter spoke of Singapore's asset disclosure rules for civil servants (and 
confiscation) (Mathews 2001), Wiedemann suggested that Hun Sen and his Council of Ministers could immediately require high-level officials to publish a list of their own personal assets and to account for the sources of their wealth (Wiedemann 2001).

The Ministry of Foreign Affairs and International Cooperation (MFAIC) issued an unsigned but official letter to foreign delegations stating that the Ministry 'deeply regrets that recently, certain ambassadors have performed their behavior like instructors teaching the Royal Government of Cambodia ... More seriously, the said ambassador has also used inflammatory words inciting revolt against the Royal Government of Cambodia' (quoted in Dittmeier 2001). The conference was unprecedented in the vociferousness of criticism by diplomats and in the issuance of a formal note by the MFAIC to Embassies subsequently. It marked a turning point in Cambodia's exercise of sovereignty and independence towards the International Community. ${ }^{43}$ This was crystallized in 2005 when, in a speech, the Prime Minister said 'I request that donor countries give Cambodia back her sovereignty. Because I think that Cambodia loves herself more than others love her ... It appears to me that the government of a sovereign country is under pressure from donor countries' (quoted in Kong 2005).

The resolve of previous promises to reform, however, appears to have melted in the face of political-economy and patronage-politics considerations. Indeed, the discrepancy between words and actions became so acute that in 2004 the World Bank's background document for the CG put it bluntly: Cambodia at the Crossroads. As made apparent by the development outcomes earlier elaborated - across infant and child mortality, inequality, and corruption - progress has been perilously slow.

\section{CASE STUDIES}

Two case studies are presented next to showcase the complex nature of RGC-donor relations. These are (1) the budgetary crisis caused by the events of July 1997 and (2) the case of logging as 'independence' from donors. The first case study shows how the withdrawal of aid produced changes in policy - chief among them the significant improvement of revenue collection because a Value-Added Tax (VAT) was introduced by 1999. The increase in domestic revenues ties directly into issues of state capacity and regime legitimacy as more tax revenues reduce the country's need to borrow, thus reducing the need for aid. ${ }^{44}$ The second case study 
shows signs, in early 1997, of tension between Cambodia and its donors - over logging - which was seen as both a way out of the grip of donors (because of its lucrative revenues) and a major source of headaches for the RGC from donors. Lessons learned are then presented.

\section{Case Study 1: Budgetary Crisis Caused by the Events of July 1997}

After the events of July 1997, a quarter of aid was frozen and the IMF pulled out over governance problems (civil administrative reforms and forestry management). The RGC faced, for the first time, a hard budget constraint. Whereas before, donor resources were fungible, the curtailment of aid had immediate consequences on budgetary expenditures. Based on Table 6:1, total donor disbursement decreased from US\$518 million in 1996 to US\$383 million in 1997. According to United Nations (2000):

This reduction was directly related to the suspension of aid by some donors, notably the United States and Germany (subsequently restored). Other countries took up a wait-and-see attitude - in most cases maintained throughout the national elections in mid-1998 - resulting in long delays in the implementation of many development programs and projects.

United Nations 2000: 99

During this period of hardship, real belt-tightening took place. In 1998, an adviser to the Ministry of Economy and Finance warned that 'In the first six months of 1997, we went through nine months of budgeted expenditure. And with no budget support from the World Bank or IMF, the national bank printed money. I'm afraid if the political situation is not resolved by the end of this year [1998], [the value of the riel] will be a big, big problem' (Quoted in Eckardt 1998). A more colourful unnamed Southeast Asian diplomat astutely commented at the time:

Aid is the key to sustain them and get them going. Right now [October 1998] the government coffers are empty. For three months the military and police have not been paid. This is why crime is up. A businessman told me that an army colonel came to see him, begging for $\$ 200$ so his men could eat. The Chinese business community is frightened of kidnapping which are getting down to the small fry a bakery manager kidnapped for $\$ 1000$ ransom ... The situation is serious and getting worse. Even investments in entertainment $[s i c]$ a cowboy country, cheap wine, women, gambling are suffering.

Ibid. 
In the austerity of 1998, a fiscal crisis emerged. The quick and dirty solution was to print more money, which led to an immediate slip in the exchange rate and inflation to spike (14 per cent annually that year).

Reform through crisis is nothing new in much of the developing world, ${ }^{45}$ but this was the first time since 1994 that a budgetary crisis had left the RGC without any choice but to undertake serious reforms. The IMF Article IV Consultations completed on 17 March 1999, following the Fund's return to Cambodia, provided Executive Board Directors an opportunity to lash out at the RGC's poor performance. According to an IMF Public Information Notice:

Directors expressed disappointment that, in 1998, economic growth halted, the riel depreciated, inflation increased considerably, and there was little tangible progress in addressing key structural reforms. Of particular concern was the continued poor fiscal performance, characterized by extensive ad hoc tax exemptions, overspending on the military budget, and sizeable central bank financing of the government.

Against this background, Directors welcomed the authorities' recently announced commitment to break away from the past record of poor governance and weak economic policies and performance. They urged the authorities to fully carry out this commitment. Directors emphasized in particular that it was critical to increase transparency and accountability, adhere to the rule of law, take decisive actions against corruption and illegal logging, and improve fiscal management. Firm implementation of these reforms, together with prudent macroeconomic policies, would help lay the foundation for sustainable growth over the medium term.

IMF 1999

Specifically, on 29 September 1999 a Letter of Intent and Memorandum of Economic and Financial Policies for 1999-2000 was signed by Keat Chhon and Chea Chanto, Minister of Economy and Finance and Governor of the National Bank of Cambodia respectively, addressed to the Managing Director of IMF. It stated that 'The new government, formed in November 1998, is determined to break with the past. It has announced measures and taken actions against illegal logging and corruption and to strengthen fiscal management. It intends to reinforce these actions and also resume other structural reforms' (RGC 1999). In October 1999, the RGC embarked on that IMF-supported programme, which ended in 2003. Domestic revenue, which had been 8.1 per cent of GDP in 1998 jumped to 10.2 per cent of GDP in 1999, a staggering 2.1 percentage points or a 26 per cent increase, 
thanks in large part to the introduction of the 10 per cent VAT. From 1999 to 2000 , domestic revenue grew by only 0.2 percentage point, though by 2001, it was reported to be 11.7 per cent of GDP (with tax revenue of 8.4 per cent of GDP, and direct taxes valued at 1 per cent of GDP). Since then, however, performance has not kept up, stalling at circa 12 per cent, and projections of increases have failed to materialize. Neighboring Vietnam fared much better (20.6 per cent total domestic revenue, 15.6 per cent tax revenue and 5.5 per cent direct taxes, respectively), while Lao PDR was on par with Cambodia in terms of total revenue (11.4 per cent of GDP), but performed markedly better in the area of tax revenue ( 9.2 per cent) and direct taxes (2 per cent). Indeed, other comparable countries to Cambodia are sub-Saharan African: Niger (8.9, 8.3, and 1.5), Tanzania (11.8, 10.6, and 2.7), and Togo $(13.8,12.3$, and 0.4$){ }^{46}$

Over the following years, donors continued to give the authorities space to manoeuvre and took on the view that reform was progressing, even if slowly. One might even say that the threat of withdrawal lost credibility among donors, as they accepted superficial compliance and returned to business as usual. The case of the events of July 1997 and the budgetary crisis that ensued suggests that while some reforms were achieved when the RGC faced its worst crisis of political legitimacy, little should be expected in the long term for this reason. The glimmer of state capacity in the VAT was sustained only temporarily - subsequent years saw a levelling off of domestic revenues as a percentage of GDP. Judging from the above, neither good governance nor political legitimacy can be created through external aid alone.

\section{Case Study 2: Logging As Independence (1995-2005)}

Logging has long been a sore point in Cambodian donor-government relations. In the early to mid-1990s illegal logging ran amok. The logging was partly linked with the need to raise revenues for a parallel military budget to fund offensives against the Khmer Rouge (GW 1997) but then took on a life of its own. By early 1997, Hun Sen had had enough of donors' (but in particular, the IMF's) threats to cut off budgetary support if illegal logging continued. He said:

I don't want to keep going around begging for money... If they [aid donors and lending groups] cut off assistance, it can mean the cutting of more trees. That is the only choice left. There is no reason for the IMF to not continue providing assistance to ... Cambodia ... Because what the royal government 
had to do has already been completed ... If they give, let them give; if not, we have to think of the way for self survival.

Quoted in AP 1997

He added that aid donors and lending groups should 'reconsider what economic pressure is all about'. In March 1997, the NGO Global Witness (GW), which would later become the RGC's official forestry monitor in the Second Mandate (only to be forced out in April 2003), obtained documents proving that, despite political tensions, the then co-Prime Ministers, Norodom Ranariddh and Hun Sen, cooperated to obtain revenues for a parallel military budget for the Royal Cambodian Armed Forces (RCAF). Both Prime Ministers gave written permission to RCAF Commander-inChief General Ke Kim Yan to sell 30,000 $\mathrm{m}^{3}$ (worth a minimum of US\$9 million at world rates) of allegedly already felled timber which had been 'confiscated' in Koh Kong Province in order to raise money to fund the 1995-1996 dry season offensive (GW 1997). Since 1999, the RGC has pledged to reduce military spending (officially 20 per cent of the budget in 1998 and 14 per cent in 2002) and increase social sector spending, but budget credibility is very weak, and year after year the military exceeds its budget allocation while health, education and welfare are shortchanged (Adams 2001). Because of non-transparent parallel budgets, how much is spent on defence is unclear; one estimate puts it close to US\$300 million (Richardson 2005) or almost half the official government budget, while another puts it at c.US\$100 million in $2001 .{ }^{47}$

With the passage of a Forestry Law in 2002, the RGC announced a ban on logging in January 2002, and a ban on log transport in May 2002, as a means of compelling logging concessionaires to produce sustainable forest management plans. Critics however charge that these bans have been violated. Shortly thereafter, things again soured between GW and the RGC. At the 2002 CG meeting, the RGC announced that GW would be expelled from the country. But while great pressure was put on GW, they remained until September 2005, when threats against staff forced the closure of the office (Informant N, 9 February 2006). In 2003, Hun Sen declared 'I think the donors are like relatives and closest friends of Cambodian government, and they do not have intention to force the government which is their blood relative to marry a partner [Global Witness] that she does not love' (quoted in AFP 2003). 
In December 2004, the transport ban was officially lifted and within months the World Bank recommended that the RGC approve the forest management plans of six companies with dubious histories (GW 2005). While it is unclear why the Bank acquiesced to the authorities on ending the moratorium, what is apparent is that the selection of the Swiss concern, Société Générale de Surveillance (SGS), as the government's new official forestry monitor was much more to the authorities' liking than had been Global Witness. SGS takes an arm's-length approach by performing occasional aerial surveillance of forested areas to monitor illegal logging activities. It accepts written forestry complaints only at its office. As of 10 March 2006, SGS stated 'To date we have not provided an email address for reports of forest crime. We will consider doing so in the future' (Informant S, 10 March 2006).

In February 2005, with the help of Global Witness, a group of Cambodian villagers lodged a complaint with the Bank's Inspection Panel. They alleged that the World Bank, through its Forest Concession Management and Control Pilot Project in Cambodia, had consistently promoted the interests of the concession system and operators, despite evidence that they inflict harm on forest-dependent communities; that through its acts and omissions, the Bank had undermined laws, standards and other accountability mechanisms designed to protect the interests of forest-dependent Cambodians; and by allowing its project to endorse the management plans of six companies, the Bank had significantly increased the likelihood that these companies would continue to maintain their logging concessions and go on inflicting material harm on local people (GW 2005:6).

In March of that same year the Panel recommended to the Bank's Executive Directors that it undertake a full investigation. The case of the RGC's struggle with illegal logging over the last decade follows the ebb and flow of power between the authorities and donors. At its nadir, the RGC was forced to accept as its official monitor a group that it had despised for years. At its zenith it could fire that same monitor and exercise its sovereignty by declaring members of the group personae non gratae (ABC 2005).

\section{What Do the Case Studies Teach Us?}

Both the events of July 1997 and the moratorium on log transport through December 2004 pressed the authorities to find alternative sources of revenues to diversify the country's donor portfolio, which has weakened 
the leverage exerted by traditional donors. Indeed, Cambodia has actively tapped non-traditional donors like China, South Korea and Pakistan. ${ }^{48}$

South Korea pledged US\$25 million at the March 2006 Consultative Group meeting. On 21 March 2006, Hun Sen met with South Korean President Roh Moo-hyun during an official visit to Seoul. They agreed to enhance bilateral ties in terms of economy, culture, tourism, infrastructure development and labor (AKP 2006). Roh Moo-hyun in turn is scheduled to make an official visit to Cambodia in November 2006 to finalize an aid package which will include upgrading National Route 3 (Yun 2006b). Moreover, about 20 students are currently studying for their Master's degrees in Korea on Korean Government scholarships, while hundreds of Cambodian workers are currently employed in Korea and remitting money home.

Marks (2000) reports that in February 1999, following an official visit to Beijing by Hun Sen, the country obtained US $\$ 18.3$ million in foreign assistance guarantees and US $\$ 200$ million in no-interest loans for infrastructure projects which China acknowledges is one of the highest aid amounts they provide to any country in the world. In July 2005, Hun Sen returned from China with approximately US\$400 million in loans, grants and promised investment (Shaw and Pin 2005). On 11 April 2006, Hun Sen praised China's announcement that it pledged US\$600 million in foreign aid to Cambodia, by saying 'Six hundred million is equal to the [2006] CG, and it has no conditions and no benchmarks ... I asked [Chinese Prime Minister] Wen Jiabao to help me, China talks little but does a lot' (quoted in Yun 2006a).

Whether true in practice or not, China in particular is regarded from Africa to Asia as a country that exerts backdoor diplomacy and does not meddle in a host country's internal political affairs (particularly not human rights and democracy). This view was reportedly confirmed by ruling party officials when critics pointed to China's growing influence in Cambodia (Chun 2005). According to Elizabeth Sidiropoulus of the South African Institute of International Affairs in Johannesburg, African countries think it is 'great' that Chinese aid and investment come with no strings attached in contrast to 'the sometimes onerous conditionality of the West' (quoted in Liu 2005). After his 19 May 2000 meeting with Li Peng, Hun Sen, who had just requested a further US\$60 million in aid, heaped praise on China, claiming that '... they never interfere with a country's internal affairs' (quoted in Liu 2005) in contrast to western donors and Japan who have 
attempted to link aid to good government, respect for human rights, and military and civil service reforms. China's aid 'is given with fewer obvious strings attached and includes military aid - [in 2002] US\$2.4 million. At the time of the summit China announced it was forgiving all of Cambodia's foreign debt to China, most of which apparently dated to the Khmer Rouge period' (quoted in Liu 2005). The more lenders Cambodia has, the less power Cambodia's lender of last resort (the IFIs) will exert over it. To be sure, this was only a natural response to a painful lesson learned in the aftermath of the events of July 1997.

From a traditional donor perspective, a coordinated approach to decrease aid would imply increasingly hard budget constraints for the RGC, which would send a signal to the authorities that good domestic (but particularly tax) revenue performance cannot be substituted with aid. This would give the right incentive and send the appropriate signal to the RGC to improve domestic revenue performance further, well beyond current levels which - at only 12 per cent of GDP - are some of the lowest in the world, comparable to Niger, Tanzania and Togo, and remain insufficient for fiscal sustainability without external assistance. ${ }^{49}$ More aid, in effect, enables authorities to postpone desperately needed reforms.

This has largely been attempted with the introduction of PerformanceBased Allocations (PBAs) using Country Policy and Institutional Assessment (CPIA) scores by the World Bank and, recently, by the ADB through its CPIA-equivalent known as Country Performance Assessment (CPA). The CPIA and CPA represent steps forward. In 2005, the World Bank disclosed that year's CPIA scores. Prior to 2005, it was not permitted to disclose scores publicly, even though doing so could have provided an incentive for decision-makers to improve performance. In the case of Cambodia, then World Bank President James D. Wolfensohn did reveal that 'We have reduced our lending to Cambodia - a response to the poor performance on governance indicators - but we have not reduced our commitment, nor our efforts to push for the kinds of reforms that are needed to bring about a better life for all Cambodians' (quoted in World Bank 2005a).

Finally, one factor that should be taken into consideration is the role of debt-servicing payments which have already begun. In May 2004, the media reported that Cambodia would pay an estimated US\$4-5 million (or the equivalent of about two per cent of total government spending, according to Kay (2004)) $)^{50}$ for concessional loans incurred after 1993. The IMF reported on its website that Cambodia was due to pay 6.52 million 
Special Drawing Rights (SDRs) ${ }^{51}$ or US\$10 million to the Fund in 2005. On 20 December 2005 that debt-servicing payment was cancelled unilaterally by the Fund as it forgave US $\$ 3.3$ billion in debts from 19 of the world's poorest countries, among them Cambodia, which received a total of US\$82 million in debt-relief, encompassing all the country's liability to the Fund.

Eventual debt-service payments may serve as a similar budgetary constraint that could encourage governance reform and increase political legitimacy if domestic revenues consequently improve. ${ }^{52}$ Cambodia's total national debt picture is unclear because negotiations with the United States to whom Cambodia may owe US $\$ 500$ million and Russia (US\$1.6 billion) have not yet been completed. At issue is the discounting of the debt and the exchange rate to be used. Debt sustainability analysis undertaken by the IMF suggests that 'the fiscal burden of the debt is heavy (given the low revenue to GDP ratios), with debt service amounting to more than 15-20 per cent of revenue over the next ten years' (Hang 2003:10). Moreover, according to the World Bank (2004a: 13), by 2008, after a rescheduling of its pre-1993 obligations, ${ }^{53}$ Cambodia's external debt is estimated to be about 48.9 per cent of GDP, and debt service will equal 2.6 per cent of exports of goods and services. While this is not large in relative terms, given Cambodia's low revenue to GDP ratios, the Bank reiterated the concern that the 'fiscal burden of the debt is heavy' (World Bank 2004a:13). It would be a pity for the people of Cambodia if only the burden of debt repayments could lead to reforms and a fundamental transformation of its low governance equilibrium.

\section{CONCLUSION}

What regime legitimacy has Cambodia achieved in the last decade with donor support in light of development outcomes and within the constraints of the country's political economy? Cambodia and the term 'failed state' were increasingly uttered together by the late 1980s. Aid was desperately needed in the early period following UNTAC, but weaning the country off aid has been difficult. A senior diplomat compared it to parents having to let go of a child - to enable and empower the child to obtain confidence (Informant H, 10 March 2006). At separate levels, there has been progress in both internal and external legitimacy in this period. While it is debatable how much internal legitimacy was successfully achieved using aid, external legitimacy has enjoyed significant success. 
The RGC has sought international recognition on the world stage by obtaining membership in all important international and regional forums, while systematically establishing a democratic autocracy. In its quest for political legitimacy, the RGC has consequently sought a donor stamp of approval even while its actions and development outcomes deviate far from donor and civil society expectations. The cloak of stability and the projection of democracy have satisfied donors whose incentives are to disburse, to advance their country's foreign policy (in the case of bilateral donors), to maintain good relations with host governments, and, of course, to be promoted to bigger and more important country postings.

The outcome of a decade of Cambodian development following UNTAC suggests that while the overall macro-economic picture appears healthy, with moderate growth of around 7 per cent per year, ${ }^{54}$ there are troubling signs of sagging human development, rising inequality and corruption. As of 2006, no anti-corruption law had yet been passed after more than a decade of discussion. The result of one decade of aid, development and corruption has shown the commingled and negative effects of aid dependence and 'Dutch disease' on state capacity and governance.

First, state capacity is weakened when the best and brightest are neither entrepreneurs nor government policy wonks. Talent is siphoned from the private and public sectors to work for donor agencies, which pay salaries that can fetch more than US $\$ 2,000$ per month. Weak state capacity consequently has had a detrimental impact on political legitimacy. Second, the authorities' inability to increase tax revenue collection tied in part to the availability of foreign aid may in turn undermine regime legitimacy as a vicious circle develops in which tax evasion becomes the norm and few services are delivered, proving the truism 'You get what you pay for.' To reverse this vicious circle may be the crucial process needed to reconstruct a state with popular legitimacy and enhance state capacity.

With respect to governance, Cambodia's struggle with controlling corruption and its experience with the politically-induced budgetary crisis of 1997 showed that improvements in domestic revenue collection strengthened state capacity and regime legitimacy, but that these were unfortunately short-lived as a resolve to permanently increase revenues floundered. The Council of Ministers approved a land tax in 2006, but the plan was scuttled by the Banking and Finance Committee of the National Assembly when standing committee members of the ruling Cambodian People's Party objected (Informant P, 11 February 2006). All of this 
has proved the remark shared by the head of a donor agency that 'The government understands donors better than the donors understand the government' (Informant E, 6 February 2006).

Annual consultative group meetings became opportunities to display donors' endorsement of the RGC and its policies by equating pledges that exceeded RGC requests as a 'vote of confidence'. Conditionality was papered over. Continuity and change in the RGC's relationship with donors show that at its low, Cambodia was forced to marry a partner (forest monitor Global Witness) it did not want. At its high, Cambodia publicly announced its divorce from this partner - preventing the organization's staff from entering the country. At some level, aid has de facto allowed the RGC to not reform and to not improve tax revenue collection, but it has allowed the authorities to 'buy' through patronage the loyalty of middle level government civil servants, necessary but not sufficient for real internal legitimacy to be achieved. Aid alone cannot substitute for a true democratic process.

This chapter has shown that Cambodia has coped with aid dependence and embraced normalcy by attempting to transform these into political legitimacy throughout much of the last decade. That transformation has not been completely successful. Where it has succeeded most is in building external political legitimacy. Of course, while the Prime Minister may never be received on an official visit by the White House, he has already been welcomed at the Élysée Palace in Paris by the President of France, at the General Assembly of the United Nations in New York, and widely in regional capitals including Beijing and Seoul. Cambodia has been accepted worldwide and is 'slowly becoming a normal country'. Of course, normal, like beauty, is in the eye of the beholder.

\section{AUTHOR'S NOTE}

I thank the unnamed informants cited in this chapter. I am grateful to the editors, and David K. Leonard and Chamnan Lim for comments and suggestions made on earlier drafts. Excellent research assistance was provided by Sophorl Pete Pin. The usual caveats apply; all remaining errors are my own. 


\section{NOTES}

1 This was estimated by World Bank (1994) at almost 4.6 per cent of GDP in 1992. Subsequent revisions have lowered this figure, but this was the best available information at about that time.

2 The definition of political legitimacy used in this chapter encompasses that found in Chapter 1 of this volume. Political legitimacy is a multi-faceted concept including rule of law, working institutions and popular consent. Legitimacy has to be won internally and externally and the major resource for both reconstructing society and establishing democracy, as will be seen in this chapter, originates from external sources.

3 This is true even though its first loan ever was to postwar France and its nonconcessional loan window is still known to this day as the 'International Bank for Reconstruction and Development'.

4 The Post-Conflict Fund is intended to enhance the World Bank's ability to support countries in transition from conflict to sustainable peace and economic growth.

5 Cambodia would qualify for state failure at least in the 1970s onwards because of its considerable experience of civil, revolutionary and ethnic wars (if one includes genocide) as defined by Esty et al. (1998) and cited by Wallensteen (2000). Using the Government of Canada's (2003) characterization of Colombia as suffering incipient state failure, Cambodia could arguably fall under this category today. Canada defines incipient state failure as the collapse of a state's structure, authority, law and political order. This includes systemic impunity, failure of the justice system, and lack of faith in political structures. These are widely recognizable in the present day context of Cambodia.

6 As Migdal (1988: xi) asks 'Why do some states succeed more and some less in realizing the vision of their leaders? The main issues will be state capabilities or their lack: the ability of state leaders to use the agencies of the state to get people in the society to do what they want them to do.' More operationally, it can alternatively be defined as the ability to collect income and other taxes, i.e., to 'the extent that state capacity is defined as the capacity to secure compliance with formal legal directives, the corruption of this key principal-agent relationship means that state capacity is undermined. Thus, it is common to speak of states with low rates of tax collection, uneven enforcement of laws and regulations, and high levels of graft as "weak" states' (Darden 2002).

7 Kaufmann et al. (1999) identify six dimensions of governance: voice and accountability, political stability, government effectiveness, regulatory quality, rule of law and control of corruption. The political economy of aid and governance is studied in Ear (2006; 2007a; 2007b)) using a survey of donor success across these various dimensions of governance in Cambodia.

8 A Cambodian expatriate (Q, 22 April 2005) with over a decade's worth of experience in the country argued that up to 1994 the bureaucracy and organs of power were, in practice, far more effective than today. A foreign expatriate (R, 26 April 2005) with even more experience in the country claimed that donors arrived with the preconceived notion that civil servants had little or no capacity and could not be trusted with any responsibility. In fact, it is a truism that things probably got done back then. Today, policies loiter on paper as the quaint aspirations of an earlier age. 
9 This chapter draws on nearly two years of fieldwork in Cambodia during which time nearly 200 formal interviews and a survey were conducted with senior government officials, donor and NGO representatives, the private sector and representatives from civil society. On that basis, it brings together qualitative input from nearly 20 of these informants. Naturally, there is no scientific basis to the sampling other than to seek relevant informants. Interviews took place without interpreters in the language in which the interviewee felt most comfortable (English, Khmer or French). The work was carried out during 2004-2005 as part of my PhD field research (see Ear 2006), which studied the political economy of aid, governance and policy-making. Information from informants used in this chapter is coded (A through S) to protect identities, but a complete list is shown in 'Informants' at the end of the chapter.

10 This phenomenon implies the deindustrialization of a nation's economy and was first observed in the Netherlands in the 1960s, when large reserves of natural gas in the North Sea were first exploited. In the case of Cambodia, aid crowds out other sectors, becoming a tradable sector financed by 'revenues' in the form of aid.

11 The statistics used in this chapter come from the World Development Indicators (WDI) Online when accessed in 2005 and 2006. At the final revision of this chapter, partly revised WDI Online statistics were released that will need to be considered in future research. The statistics appear to show a peak in 1995 for infant and child mortality, and then subsequent declines in 2000 and 2005. Not surprisingly, these declines fall below the 1990 values by 2000, which result in an overall improvement in conditions for the decade and further improvement by 2005. However, the Bank's own authoritative report 'East Asia \& Pacific Update: 10 Years After the Crisis' released in April 2007 contradicts this trend: 'The infant mortality rate (per 1,000 live births) fell from 95 in 2000 to 66 in 2005 and child (under 5) mortality (per 1,000 live births) decreased from 124 in 2000 to 83 in 2005 . HIV prevalence also appeared to have fallen remarkably. The notable lagging indicator is the maternal mortality rate, which likely remains unchanged over the past five years.' (World Bank, 2007: 47) The current WDI Online infant and child mortality values for the year 2000 (77.7 and 103.2, respectively) found in World Bank (2008) are the result of a simple average (i.e., linear extrapolation) of 1995 and 2005 values. In fact, the Cambodia Demographic and Health Surveys of 2000 and 2005 are the most reliable estimates for 2000 and 2005 and the source for the Bank's April 2007 report as well as Unicef's (2007: 116) State of the World's Children 2008. And while the CDHS 2005 - analyzed in National Institute of Public Health et al., (2006: 124-125) - shows a sharp improvement in 2005, it also confirms that from 1990 until at least 2000, infant and child mortality worsened - a central piece of the puzzle elaborated in this chapter.

12 The events saw the first Prime Minister go into exile, and more than 50 of his supporters killed.

13 Hundreds of thousands of Cambodians became refugees. Most of these were received by the US.

14 It is well known for example that macroeconomic models of the economy hinged on educated guesses and suppositions since little primary data existed. (Informant G, 26 January 2006)

15 This was in essence the Council for Mutual Economic Assistance/Comecon.

16 This was subsequently revised downward. The figure is used here to denote the severity of the situation with what was then the best available information. 
17 This is true albeit from a very low base.

18 Indeed, a perusal of the titles of World Bank reports published in 1994-97 tells the story of transition: From Rehabilitation to Reconstruction (World Bank 1994); Rehabilitation Program (World Bank 1995); From Recovery to Sustained Development (World Bank 1996); and Progress in Recovery and Reform (World Bank 1997).

19 Four years after UNTAC, the 'events of 5-6 July 1997' threw the economy into chaos, further highlighting the country's dependence on aid. The factional fighting sank the economy with at least US\$100 million in damage. Foreign Direct Investment steeply declined in the aftermath of the events of July 1997, and has only in recent years recovered. The 29 January 2003 anti-Thai riots, which resulted in the burning of the Thai Embassy along with the Royal Phnom Penh Hotel and other Thai business interests, were the main setback of the early post-millennium period, costing the country millions of dollars in damage. Foreign observers of the self-inflicted mayhem at the time were angered by some rioters' attitude that destroyed property would simply be rebuilt with other people's money.

20 See Table 6:1 below and sum all disbursements shown in row 3, taking note of the preceding year for the start and end periods.

21 The national poverty line is used to calculate the national poverty rate and is designed specifically for Cambodia based on a caloric intake of c.2,200 per day per person. The international poverty line is defined as 'US\$1 per capita per day, 1990 PPP' (World Bank 2006b). PPP stands for Purchasing Power Parity and represents the purchasing power of US\$1 in the United States in 1990. When adjusted for inflation and cost-ofliving differences between countries, it comes out as 1,382 Riels (less than US\$0.35) per person per day in Cambodia in 2004 and is thus below the national poverty line of US $\$ 0.45$ per capita per day.

22 Professionalizing the bureaucracy would take away power from the authorities in making discretionary decisions and would disrupt embedded networks of influence.

23 According to World Bank (1998: 130), 'fungibility' is defined as the possibility for aid recipient countries to reduce their own resources in the sector that receives aid and transfer them to other sectors of the budget. As will be detailed later, Defence, Interior, and the Council of Ministers are perennial over-spenders, while Health and Education suffer.

24 According to Aristide (2000: 13), Brian Atwood, then Administrator of USAID, testified to Congress 'that 84 cents of every dollar of aid goes back into the US economy in goods and services purchased. For every dollar the United States puts into the World Bank, an estimated $\$ 2$ actually goes into the US economy in goods and services.'

25 Take 160,000 Cambodian civil servants and divide by 700 international consultants.

26 The origin of the phrase 'governance is a sine qua non' can be traced at least as far back as United Nations (1996).

27 H.E. Sok An was at the time Senior Minister, Minister in charge of the Office of the Council of Ministers, and Chairman of the Council for Administrative Reform when he spoke on 'Administrative Reform' at the 'Interim Consultative Group Meeting' on 28 January 2003 (Sok 2003).

28 An as yet unofficial estimate of growth in 2005 has put it near 10 per cent, but this will only bring up the average slightly over the decade. 
29 At the final revision of this chapter, partly revised WDI statistics were released that will need to be considered in future research. While the current best available data found in the Cambodia Demographic and Health Surveys of 2000 and 2005 and analyzed in National Institute of Public Health et al. (2006: 124-125) show a sharp improvement in 2005, it also confirms that from 1990 until at least 2000, infant and child mortality worsened - further confirmatory evidence of the thesis proposed in this chapter.

30 To compare apples to apples, the Bank took the accessible part of the country in $1993 / 94$, ascribing to it the original $39 \%$ national poverty rate, and derived a $28 \%$ poverty rate for the same area in 2004.

31 The notes were taken by Tim Carney, a senior staff member and Director of the Information/Education Division of UNTAC.

32 This is the preferred phraseology of the authorities, while it is more commonly known as a bribe tax. While the World Bank (2004b) faithfully replaces all instances of 'bribe tax' with 'unofficial payments' the find-and-replace function missed (perhaps intentionally) one instance in 'Annex III: Methodology: Productivity and Investment Climate Survey’ on page 110.

33 Bangladesh was tied with Haiti in last place at 145 out of 145. Available: http://www. transparency.org/cpi/2004/cpi2004.en.html\#cpi2004.

34 The 2005 CPI rankings are available at: http://www.transparency.org/policy_and_ research/surveys_indices/cpi/2005

35 The term has become the politically correct language for donors in Cambodia and elsewhere to the point where Timor-Leste named its CG the 'Timor-Leste and Development Partners Meeting', refusing to adopt the name Consultative Group Meeting in 2002. Moreover, meetings which regularly took place in World capitals (Paris and Tokyo) began to take place in host country capitals, Phnom Penh and Dili, respectively. According to Informant F (10 March 2006), the authorities are said to have floated the idea of cancelling future CGs altogether, preferring instead low-key quarterly Government-Donor Coordination Committee meetings. Another idea has been to chair the CG alone, instead of co-chairing it with the World Bank, which would be somewhat unprecedented given that the CG is a World Bank signature event. Symbolic control of the process is important to the authorities; some donors complain that all the authorities wish to do is to 'chair' meetings while leaving the actual work to the donors (Informant A, 17 February 2005).

36 Bettinger (2004) writes that the CG meetings are: '[an] exercise in futility in which donor nations admonish Cambodia to work harder to reign in its epidemic problems in human and drug trafficking, official corruption and environmental piracy. Each time this meeting convenes the donors threaten to stop aid to the country, the term 'donor fatigue' is bandied about quite frequently, and at each meeting the government, perpetually headed by Prime Minister Hun Sen, promises to get tough and crack down on the aforementioned problems.'

37 This is not unlike the credibility of Cambodia's annual Budget Law which bares little resemblance to actual outlays.

38 Prior to becoming Prime Minister in 1985, Hun Sen served five years as Minister of Foreign Affairs under the People's Republic of Kampuchea. 
39 From 1979-1991, Cambodia's seat at the UN was held by the GCDK (General Coalition for a Democratic Kampuchea), which really was Khmer Rouge in a coalition with the non-communist resistance.

40 The only time Cambodia appears to have ever risked not joining an international grouping was during the Asia-Europe Meeting (ASEM) 2004, when it declared that if Europe refused to permit Myanmar to join, it would not participate either as a show of solidarity.

41 Hun Sen said that 'It takes a long time to build up institutions, drafting laws that are effective. Rome was not built overnight.' This is a theme that will be repeated by Deputy Prime Minister Sok An the following year (Sok 2003).

42 Wiedemann's introduction foretold as much: 'In the spirit of transparency, I am going to speak extremely frankly this morning. I am going to use words and say things that frankly are usually not said by diplomats. I am going to speak more directly and with less circumlocution than diplomats are normally used to do,' before ending his speech: 'As I said, laws are very important and there has been some discussion this morning that Rome cannot be built in a day and that is true. You cannot expect perfection to be brought about, in resolving issues of corruption, immediately. However, with sufficient political will, very important steps can be taken immediately that would have, I think, a very important immediate impact. Without the need to wait for new laws to be developed through donor assistance and technical expertise and capacity building, and without the need for laws to be passed by the National Assembly' (Wiedemann 2001).

43 To be sure, with respect to the legacy of UNTAC - one of which was to establish a Cambodia Office of the United Nations High Commissioner for Human Rights - a goal of the regime post-1997 has been to assert its 'sovereignty' by vociferously attacking the Special Representative of the Secretary-General (SRSG) for Human Rights in Cambodia. Regarding the SRSG, Hun Sen said 'I know that [he] is a tourist who comes to Cambodia regularly. He can come to see me when he wants' (as quoted in Kong 2005). The new SRSG, Yash Ghai, who is from Kenya, enjoyed his own ad hominem attack: 'As for Ghai, I think he should think about human rights in his own country, Kenya, where, to my knowledge, the poverty rate is over 50 per cent among the population. He should pay more attention to that over there. Well, it's fortunate that I did not meet him when he arrived in Cambodia' (FBIS 2005). The Prime Minister was reportedly ill and cancelled the meeting.

44 Conversely, Feyzioglu et al. (1998) found that aid is mainly used for tax reduction. This is particularly interesting, given my point above.

45 See Grindle and Thomas (1991) for instance.

46 All revenue and tax figures come from IMF staff country reports cited in World Bank and ADB (2003: ix).

47 According to official government statistics, overall expenditure on defence and security decreased 2.4 per cent from 417 billion Riels (US\$104 million using 4000 riels/US\$ exchange rate) or 2.9 per cent of GDP in 2001 to 407 billion Riels (US\$101.8 million) or 2.6 per cent of GDP. Expenditure by Ministry of National Defense decreased 4.3 per cent from 277 billion Riels (US\$69 million) in 2001 to 265 billion Riels (US\$66 million) in 2002 (RGC 2003). 
48 Perhaps in response to India's longtime presence in Cambodia, Pakistan opened an Embassy recently and signed an agreement to loan Cambodia US\$10 million while a caretaker government, led by Hun Sen, was in place in 2004 and other, more traditional donors were unable or unwilling to make commitments.

49 This chapter has not addressed the equally important expenditure side, which to date shows few signs of progress. The World Bank has engaged in expenditure tracking for the education and health sectors. Anecdotal evidence in other areas, like Social Protection, suggests that leakage of a non-trivial amount takes place, see Chan and Ear (2004).

50 Debt sustainability analysis indicates that it is difficult to determine the exact amount of Cambodia's external debt, as the authorities are conducting negotiations with the Russian Federation and the United States on the rescheduling of its pre-1993 financial obligations.

51 An SDR is an artificial currency unit that was created by the International Monetary Fund in 1969. It is a basket of currencies that include the Euro, the $£$ sterling, the Japanese yen and the United States dollar. Using 1 SDR $=1.52577$ exchange rate of 22 March 2005, 6.52 million SDRs are worth about US\$10 million.

52 On the other hand, this incentive will be mitigated by gas and oil revenues valued in the billions of dollars over the next decade, revenues which may turn into a curse if not invested properly. Cambodia's aid-based Dutch disease may turn into the original gas- (and oil-) based Dutch disease.

53 In The Elusive Quest for Growth, William Easterly (2001) rightly argues that a major test of good governance rests on whether, after receiving debt relief, a Government increases borrowing and returns to its original overburdened and unsustainable debt levels. In the case of Cambodia, this period of uncertainty in its debt outlook should give the authorities pause over how much more (or less) to borrow.

54 Even with the as yet unofficial news of nearly 10 per cent growth in for 2005, this average will not change when divided by a decade of moderate growth.

\section{REFERENCES}

ABC (2005) 'Cambodia bans watchdog group after report on illegal logging'. Australian Broadcast Corporation Asia Pacific TV / Radio Australia, 20 July. Available: http:// www.illegal-logging.info/news.php?newsId=940.

ActionAid (2005) Real Aid: An Agenda for Making Aid Work. ActionAid International. Available: http://www.actionaidusa.org/Actionper cent20Aidper cent20Realper cent20Aid.pdf.

Adams, Brad (2001) 'Demobilization's House of Mirrors'. Phnom Penh Post, Issue 10/24, 23 November-6 December.

ADB (1995) 'Governance: Sound Development Management'. Policy Papers, WP1-95, Manila: Asian Development Bank, August. Available: http://www.adb.org/Documents/ Policies/Governance/govpolicy.pdf.

ADB, JBIC and World Bank (2005) 'Connecting East Asia: A New Framework for Infrastructure'. Asian Development Bank, Japan Bank for International Cooperation, 
and World Bank, Manila, Tokyo, and Washington, DC, 16 March. Available: http:// siteresources.worldbank.org/INTEASTASIAPACIFIC/Resources/Connecting-EastAsia.pdf.

AFP (2003) 'Environmental Group must leave Cambodia at end of Tenure: Hun Sen'. Agence France-Presse, 28 January.

AKP (2006) 'South Korea, Cambodia agree to Enhance Bilateral Ties'. Phnom Penh: Agence Kampuchea Presse, 22 March.

AP (2006) 'Cambodia promised US\$601 million in international Aid’. Associated Press, 4 March.

- - (1997) 'Cambodian Leader threatens more logging if IMF cuts Aid'. Associated Press, 25 February. Available: http://www.globalwitness.org/press_releases/article. php?id=130.

Aristide, Jean-Bertrand (2000) Eyes of the Heart: Seeking a Path for the Poor in the Age of Globalization. Monroe, ME: Common Courage Press.

Badillo, Daniel; Leonardo Garnier; Jorge Enrique Vargas and Fernando Carrera (2001) 'Chapter 8: Liberalisation, poverty-led growth and child rights: Ecuador from 1980 to 2000'. In Giovanni Andrea Cornia (ed.) 'Harnessing Globalisation for Children'. A report to UNICEF, United Nations Children's Fund. Available: http://www.unicef-icdc. org/research/ESP/globalization/chapter8.pdf.

Bettinger, Keith Andrew (2004) 'A Forest falls in Cambodia'. Asia Times, 23 November. Available: http://www.atimes.com/atimes/Southeast_Asia/GA06Ae01.html.

Calavan, M.; S. Briquets and J. O’Brien (2004) 'Cambodia Corruption Assessment'. Prepared for USAID Cambodia by United States Agency for International Development and Casals \& Associates. May-June, submitted 19 August.

Chan, Sophal and Sophal Ear (2004) 'Towards Understanding Social Protection in Cambodia'. Cambodian Development Review, Vol. 8, Issue 4, Cambodia Development Resource Institute, October-December. Available: http://www.csua.berkeley.edu/ $\sim$ sophal/sp.pdf.

Chun, Sakada (2005) 'China is Seen to Ease Political Tension in Cambodia'. Voice of America, Washington, DC: U.S. Government, 8 November.

Dittmeier, Charles (2001) 'Strong Words Back to the US Ambassador'. Analysis and Comment on the Society and Politics of Cambodia, 30 August. Available: http://www. parish-without-borders.net/cditt/cambodia/cb-politics01.htm.

DPA (2002) 'Despite Criticism of Reform, Cambodian Donors pledge Record Windfall'. Deutsche Presse-Agentur, 21 July.

Ear, Sophal (1997) 'Cambodia and the Washington Consensus'. Crossroads: An Interdisciplinary Journal of Southeast Asian Studies, Vol. 11, No. 2, pp. 73-97, DeKalb, IL: Northern Illinois University.

- - (2006) 'The Political Economy of Aid, Governance, and Policy-Making: Cambodia in Global, National, and Sectoral Perspectives'. PhD dissertation, Department of Political 
Science, Berkeley: University of California, Spring. Available: http://csua.berkeley.edu/ $\sim$ sophal/ear_diss.pdf.

- - (2007a) 'The Political Economy of Aid and Governance in Cambodia'. Asian Journal of Political Science, Vol. 15, Issue 1, pp. 68-96, Singapore: National University of Singapore, April.

-_ (2007b) 'Does Aid Dependence Worsen Governance?' International Public Management Journal, Vol. 10, No. 3, pp. 259-286, Philadelphia, PA: Routledge, published for the International Public Management Network.

Easterly, William (2001) The Elusive Quest for Growth: Economists' Adventures and Misadventures in the Tropics. Cambridge, MA: MIT Press.

Eckardt, James (1998) 'Economy Given Two Months to Meltdown'. Phnom Penh Post, Issue 7/23, 16-29 October.

Esty, Daniel; Jack Goldstone; Ted Gurr; Barbara Harff; Pamela Surko; Alan Unger and Robert Chen (1998) 'The State Failure Project: Early Warning Research for U.S. Foreign Policy Planning'. Paper to the Conference on Failed States and International Security: Causes, Prospects and Prospects and Consequences, Purdue University, 25-27 February.

FBIS (2005) 'Cambodian Premier on Fate of Sam Rainsy, Opposition Party, US Military Aid'. SEP20051229021001, Phnom Penh Television Kampuchea (TVK) in Cambodian, Cambodia's national television in Khmer at 0600 GMT, 29 December.

Feyzioglu, T., S. Vinaya and Z. Min (1998) 'A Panel Data Analysis of the Fungibility of Foreign Aid'. World Bank Economic Review, 12(1), 29-58, Washington, DC: World Bank.

Godfrey, Martin; Sophal Chan; Toshiyasu Kato; Piseth Vou Long; Dorina Pon; Saravy Tep; Savora Tia and Sovannarith So (2000) 'Technical Assistance and Capacity Development in an Aid-dependent Economy: The Experience of Cambodia'. Working Paper 15, Phnom Penh: Cambodia Development Resource Institute, August.

Government of Canada (2003) 'Interim Country Development Programming Framework for Colombia'. Ottawa: Government of Canada, 19 March. Available: http://www.acdicida.gc.ca/cida_ind.nsf/0/f6e700da8e7eb2f085256cde0050334f?OpenDocument.

Grindle, Merilee and John Thomas (1991) Public Choices and Policy Change: The Political Economy of Reform in Developing Countries. Baltimore, MD: Johns Hopkins University Press.

GW (1997) 'A Tug of War: The Struggle to Protect Cambodia's Forests'. A Briefing Document by Global Witness, March.

Available:http://www.globalwitness.org/campaigns/forests/cambodia/tugowar/tugofwar. html.

GW (2005) 'Submission to the World Bank Inspection Panel: World Bank Forest Concession Management and Control Pilot Project in Cambodia'. Prepared for NGO Forum on Cambodia by Global Witness, February. Available: http://www.globalwitness.org/ campaigns/forests/cambodia/Febper cent2005per cent20Worldper cent20Bankper cent20Inspectionper cent20Panelper cent20Briefingper cent20Document.pdf. 
Hang, Chuon Naron (2003) 'Cambodia - Macroeconomic Outlook Presentation by Dr. Hang Chuon Naron, Deputy Secretary General, Ministry of Economy and Finance for H.E. Naoyuki SHINOHARA, Deputy Director-General, International Bureau, Ministry of Finance, Japan'. Phnom Penh: Royal Government of Cambodia , 7 April. Available: http://www.mef.gov.kh/SpeechDr.Naron/speechnaron1.pdf.

Heder, Steve (2006) 'PDK Zones “Prosperous”'. E-mail communication, 10 April.

Hun, Sen (1999) 'Closing Speech of Samdech Hun Sen, Prime Minister of the Royal Government of Cambodia, at the Donor Monitoring Meeting Phnom Penh'. Phnom Penh: Royal Government of Cambodia, 14 June. Available: http://www.camnet.com. kh/ocm/government23.htm.

- - (2001a) 'Closing Address of Samdech Hun Sen, Prime Minister of the Royal Government of Cambodia, at the Government-Donor Monitoring Meeting Phnom Penh'. Phnom Penh: Royal Government of Cambodia, 29 January. Available: http:// www.camnet.com.kh/ocm/government64.htm.

- - (2001b) 'Closing address at the 2nd National Conference on the Implementation of the Government's Political Platform for Social Development and Poverty Reduction'. Cambodia New Vision, Issue 38, Phnom Penh: Royal Government of Cambodia, March. Available: http://www.cnv.org.kh/cnv_html_pdf/cnv_38.htm.

- - (2001c) 'Opening Address of Samdech Hun Sen, Prime Minister of the Royal Government of Cambodia, to the Second National Conference on the Implementation of the Government's Political Platform for Social Development and Poverty Reduction'. Phnom Penh: Royal Government of Cambodia, 12 March. Available: http://www. camnet.com.kh/ocm/government69.htm.

- - (2002) 'Address at the Launching of the Cambodia Socio-Economic Development Plan 2001-2005 SEDP-II'. Phnom Penh: Royal Government of Cambodia, 29 July. Available: http://www.cnv.org.kh/2002_releases/290702_socioeco_devplan_second.htm.

IMF (1999) 'IMF Concludes Article IV Consultation with Cambodia'. International Monetary Fund Public Information Notice (PIN) No. 99/30, 6 April. Available: http:// www.imf.org/external/np/sec/pn/1999/pn9930.htm.

Kaufmann, D., A. Kraay, and P. Zoido-Lobatón (1999) 'Governance Matters'. Policy Research Working Paper, no. 2196, Washington, DC: World Bank, October. Available: http://www.worldbank.org/wbi/governance/pubs/govmatters.html.

Kay, Kimsong (2004) 'Gov't Sets Timetable to Begin Repaying Debt'. The Cambodia Daily, 28 May.

Keat, Chhon (2001) 'Presentation by Minister of Economy and Finance at the High-Level Consultations between AusAID and the Royal Government of Cambodia'. Phnom Penh: Royal Government of Cambodia, 16 May. Available: http://www.cdc-crdb.gov. $\mathrm{kh} / \mathrm{cdc} /$ australia_table_contents.htm.

Kong, Sothanarith (2005) 'Le Cambodge s'aime plus que les autres ne l'aiment' [Cambodia loves herself more than others love her]. Cambodge Soir, 15 March. Available: http:// www.cambodiapolitics.org/news/cambodge_soir/march_05/15_cs3.pdf. 
Kvasager, Whitney and Pin Sisovann (2006) 'EU Delegation Critical of UN Envoy's Report'. The Cambodia Daily, Vol. 34, Issue 22, 25 April.

Marks, Paul (2000) 'China's Cambodia Strategy'. Parameters, pp. 92-108, Autumn. Available: http://carlisle-www.army.mil/usawc/Parameters/00autumn/marks.htm.

Mathews, Verghese (2001) 'Building a Coalition for Transparency: The Example of Singapore'. Speech of HE Verghese Mathews, Ambassador of Singapore, 22 August. Available: http://www.bigpond.com.kh/users/csd/other_activity/speechmathews.htm.

Migdal, Joel (1988) Strong Societies and Weak States: State-Society Relations and State Capabilities in the Third World, Princeton, NJ: Princeton University Press.

Narayan, D. and P. Petesch (2002) 'From Many Lands'. Voices of the Poor, Vol. 3, Oxford: Oxford University Press, published for the World Bank. Available:http://www1. worldbank.org/prem/poverty/voices/reports/lands/lanconcl.pdf.

National Institute of Public Health, National Institute of Statistics [Cambodia] and ORC Macro (2006) Cambodia Demographic and Health Survey 2005. Phnom Penh, Cambodia and Calverton, Maryland, USA: National Institute of Public Health, National Institute of Statistics and ORC Macro. Available: http://pdf.usaid.gov/pdf_docs/PNADI683.pdf.

Prescott, Nicholas and Menno Pradhan (1997) A Poverty Profile of Cambodia. Report WDP 373, Washington, DC: World Bank, 31 October. Available: http://www-wds.worldbank. org/servlet/WDSContentServer/WDSP/IB/1997/10/01/000009265_3971126124351/ Rendered/PDF/multi_page.pdf.

REC (1997) 'European Union Appealed for Unconditional Aid to Cambodia'. Newsletter of the Royal Embassy of Cambodia. Washington, DC: Royal Embassy of Cambodia, August. Available: http://www.embassy.org/cambodia/newsletter/newslett97/aug.htm.

Reuters (2005) 'Corruption is Cambodia's Main Problem'. Reuters News, 11 February.

RGC (1999) 'Letter of Intent of the Government of Cambodia and Memorandum of Economic and Financial Policies for 1999-2000 to Mr. Michel Camdessus, Managing Director, International Monetary Fund'. Washington, DC: International Monetary Fund, 29 September. Available: http://www.imf.org/external/np/loi/1999/093099.htm.

- - (2004) 'Implementing the Rectangular Strategy and Development Assistance Needs'. Government Position Paper. Phnom Penh: Royal Government of Cambodia, November. Available: http://www.cdc-crdb.gov.kh/cdc/7cg_meeting/position_paper_eng2004/ 7cg_default.htm.

Richardson, Sophie (2005) 'Cambodia, the World Bank, and demobilization'. The Nation, Bangkok: The Nation Group, 1 March.

Shaw, William and Pin Sisovann (2005) 'China's Patronage Raises Concerns About Intent'. The Cambodia Daily, 13 July. Available: http://www.camnet.com.kh/cambodia.daily/ selected_features/cd -13-7-05.htm.

Sok, An (2003) 'Interim Consultative Group Meeting Speech on Administrative Reform by H.E. Sok An Senior Minister, Minister in Charge of the Office of the Council of Ministers, and Chairman of the Council for Administrative Reform'. Phnom Penh: Royal Government of Cambodia, 28 January. Available: http://www.car.gov.kh/ officialstatement/Sokan_003.html. 
UNDP (1997) 'Governance for Sustainable Human Development'. A UNDP Policy Document, New York, NY: United Nations Development Programme, January. Available: http:// magnet.undp.org/policy/chapter1.htm.

Unicef (2007) The State of the World's Children 2008: Child Survival. New York, NY: United Nations Children's Fund, December. Available: http://www.unicef.org/sowc08/ docs/sowc08.pdf.

United Nations (1996) 'Public Administration and Development Report of the SecretaryGeneral’. New York, NY: United Nations Economic and Social Council, 8 March. Available: http://www.un.org/documents/ecosoc/docs/1996/e1996 -7.htm.

- - (2000), United Nations Development Assistance Framework UNDAFCambodia: 20012005, Annex C - Overview of Official Development Assistance, Phnom Penh: United Nations Resident Coordinator's Office. Available: http://www.un.org.kh/UNDAF/13annex_c-oda_overview.pdf.

UPI (1996) 'Cambodian PM jubilant over donor aid’. United Press International, 16 July.

Vatikiotis, Michael (2005) ‘Cambodia's reluctant Democrat'. International Herald Tribune, 2 April.

Wallensteen, Peter (2000) 'Beyond State Failure: On Internal and External Ways of Ending State Failure’. Failed States Conference, Purdue University, 7-10 April.

Wiedemann, Kent (2001) 'Building a Coalition for Transparency: The Problem of Corruption in Cambodia'. Speech of HE Kent Wiedemann, Ambassador of the United States of America, Phnom Penh. US Government, 22 August. Available: http://www. bigpond.com.kh/users/csd/other_activity/speechwiedemann.htm.

Williamson, John (1990) 'What Washington Means by Policy Reform'. In John Williamson (ed.) Latin American Adjustment: How Much Has Happened? Washington, DC: Institute for International Economics.

World Bank (1994) From Rehabilitation to Reconstruction. Report No. 12667. Washington DC: World Bank, 2 October. Available: http://www-wds.worldbank.org/servlet/WDS_ IBank_Servlet?pcont=details\&eid=000009265_3961005173829.

- - (1995) Rehabilitation Program: Implementation and Outlook. Report No. 13965. Washington DC: World Bank, 27 February. Available: http://www-wds.worldbank.org/ servlet/WDS_IBank_Servlet?pcont=details\&eid=000009265_3961007222725.

-_ (1996) From Recovery to Sustained Development. Report No. 15593. Washington DC: World Bank, 31 May. Available: http://www-wds.worldbank.org/servlet/WDS_IBank_ Servlet?pcont=details\&eid=000009265_3961214134230.

-_ (1997) Progress in Recovery and Reform. Report No. 16591. Washington DC: World Bank, 2 June. Available: http://www-wds.worldbank.org/servlet/WDS_IBank_Servlet ?pcont=details\&eid=000009265_3971023103639.

- - (1998) Assessing Aid: What Works, What Doesn't, and Why. World Bank Policy Research Report. New York, NY: Oxford University Press. Available: http://www. worldbank.org/research/aid/aidtoc.htm. 
_- (1999) Cambodia: Poverty Assessment. Report19858-KH. Washington DC: World Bank, 22 November. Available: http://www-wds.worldbank.org/servlet/WDSContentServer/ WDSP/IB/1999/12/30/000094946_99122006055630/Rendered/PDF/multi_page.pdf.

- - (2004a) Cambodia: Poverty Reduction Strategy Paper Annual Report and Joint Staff Assessment. Report No: 29803-KH, Poverty Reduction and Economic Management Sector Unit, East Asia and Pacific Region, Washington DC: World Bank, 17 August. Available: http://www-wds.worldbank.org/servlet/WDS_IBank_Servlet?pcont=details \&eid=000012009_20040826111530.

- - (2004b) Seizing the Global Opportunity: Investment Climate Assessment and Reform Strategy for Cambodia. Report No. 27925-KH, Washington DC: World Bank, 12 August. Available:http://siteresources.worldbank.org/INTCAMBODIA/Resources/ Global-opportunity.pdf.

- - (2004c) The Role of the World Bank in Conflict and Development: An Evolving Agenda. Conflict Prevention and Reconstruction Unit Social Development Department Environmentally and Socially Sustainable Development Network. Washington DC: WorldBank. Available: http://lnweb18.worldbank.org/ESSD/sdvext.nsf/67ByDocName/ TheRoleoftheWorldBankinConflictandDevelopmentAnEvolvingAgenda1/\$FILE/ ConflictAgenda2004.pdf.

- - (2005a) 'World Bank Group President James D. Wolfensohn Wraps Up Visit To Cambodia, Urges: “Seize The Opportunity"'. Press Release. Phnom Penh: World Bank, 11February.Available:http://web.worldbank.org/WBSITE/EXTERNAL/COUNTRIES/ EASTASIAPACIFICEXT/CAMBODIAEXTN/ 0,,contentMDK:20352376 menuPK:29 3861 pagePK:141137 piPK:141127 theSitePK:293856,00.html.

_- (2005b) World Development Indicators Online. Washington DC: World Bank.

- - (2006a) Cambodia: Halving Poverty by 2015? Poverty Assessment 2006. Phnom Penh: World Bank, February. Available:http://web.worldbank.org/WBSITE/EXTERNAL/ COUNTRIES/EASTASIAPACIFICEXT/CAMBODIAEXTN/ 0,,contentMDK:208156 21 pagePK:141137 piPK:141127 theSitePK:293856,00.html.

- - (2006b) ‘Frequently Asked Questions about Poverty in Cambodia'. Phnom Penh: World Bank. Available: http://web.worldbank.org/WBSITE/EXTERNAL/COUNTRIES/ EASTASIAPACIFICEXT/CAMBODIAEXTN/ 0,,contentMDK:20720197 pagePK:141 137 piPK:141127 theSitePK:293856,00.html\#Q10_.

- - (2007) 'East Asia and Pacific Update: 10 Years After the Crisis'. The World Bank East Asia and the Pacific Region. Washington, DC: World Bank, April. Available:http:// siteresources.worldbank.org/INTJAPANINJAPANESE/Resources/EAP_Update_ MainReport_Final.pdf.

- - (2008) World Development Indicators Online. Washington, DC: World Bank, Accessed online on 24 January.

World Bank and ADB (2003) Cambodia: Enhancing Service Delivery through Improved Resource Allocation and Institutional Reform. Integrated Fiduciary Assessment and Public Expenditure Review, Report No. 25611 KH, a Joint Document of the World Bank and the Asian Development Bank, 8 September. Available: http://www-wds.worldbank. org/servlet/WDS_IBank_Servlet?pcont=details\&eid=000090341_20030924104425. 
Yun, Samean (2006a) 'Hun Sen Hails Beijing for Aid Without Strings'. The Cambodia Daily, Vol. 34, Issue 12, 12 April.

(2006b) 'Hun Sen: South Korean President to Visit in November'. The Cambodia Daily, Vol. 34, Issue 13, 13 April.

\section{INFORMANTS}

\begin{tabular}{llll} 
Code & Descriptor & Category & Date \\
A & Director & Donor & 17-Feb-05 \\
B & Specialist & Donor & 13-Feb-06 \\
C & Adviser & Donor & 3-May-05 \\
D & Adviser & Donor & 3-May-05 \\
E & Director & Donor & 6-Feb-06 \\
F & Adviser & Donor & 10-Mar-06 \\
G & Specialist & Donor & 26-Jan-06 \\
H & Senior Diplomat & Embassy & 10-Mar-06 \\
I & Senior Diplomat & Embassy & 24-Feb-06 \\
J & Management & Government & 3-May-05 \\
K & Adviser & Government & 2-Feb-06 \\
L & Management & NGO (International) & 3-May-05 \\
M & Management & NGO (International) & 3-May-05 \\
N & Specialist & NGO (International) & 9-Feb-06 \\
O & Management & NGO (National) & 7-May-05 \\
P & Director & NGO (National) & 11-Feb-06 \\
Q & Consultant & NGO (National) & 22-Apr-05 \\
R & Director & NGO (National) & 26-Apr-05 \\
S & Project Manager & Private Sector & 10-Mar-06 \\
\hline & & &
\end{tabular}




\section{Chapter 7}

\section{(Re)Creating Local Political Legitimacy through Governance Intervention?}

\section{Malin Hasselskog}

Interventionism has been part of development thinking and practice at least since the Second World War. The approaches and contents of development assistance have varied and changed, but throughout, the idea of intervening in order to initiate and control societal change has remained.

Implicit in the interventionist idea is an assumption of 'makeability'. Building on ideas of diffusionism and transferability, along with ideals of order and predictability, it is assumed to be possible to manage societal change, i.e. to remake society in various aspects. Such a remake makes simplification and legibility necessary and results in a managerialist approach, where certain inputs are expected to deliver certain outcomes (Blaut 1993; Hettne 2005; Olivier de Sardan 2005; Long 2001; Crewe and Harrison 1998). The 'makeability' dealt with in this chapter is the (re)creation of local political legitimacy in a post-conflict context through governance intervention.

Governance intervention ${ }^{1}$ has been common in development practice since the 1990s, entailing the introduction of socio-political structures and processes similar to those in liberal democracies. At the national level this typically involves multi-party elections, institution and capacity building, and the promotion of democratic values. At the local level, the setting up of new bodies such as elected village committees is common, along with the introduction of participatory planning and decision-making processes, and in some cases devolved development funds. Governance intervention thus implies efforts to change the political landscape and climate, assuming that liberal democracy is conducive to socio-economic development. 
Political legitimacy is a fundamental part of 'good governance', not least at the local level. Without basic levels of trust and accountability, there will not be any sustainable reconstruction and reconciliation, and decentralized governance is often assumed to be more legitimate than central governance. Reconstruction and reconciliation efforts in post-conflict societies therefore often include the introduction of an externally designed political set-up, with new local bodies, tasks and mandates, giving local authorities a role in socio-economic development. In other words, a governance intervention in a post-conflict context partly aims to (re)create local authorities' political legitimacy by turning them into accountable service providers and thus, by creating positive experiences, encourage positive expectations among the population.

\section{IMPLEMENTATION DYNAMICS}

The assumption of makeability and the ambition to control are problematic. Implementing an externally designed intervention in a social context inevitably gives rise to complex and unpredictable processes. Locally prevailing relations, rationality, norms, experiences and expectations will influence how people perceive and respond to new phenomena included in a development intervention. At the interface between what is introduced from outside and what already exists, an arena emerges where a dynamic interplay takes place, involving confrontation and contestation, mutual influences and accommodation. Rather than being readily transferred, an externally designed intervention will therefore be reshaped, as the external and the local influence each other, leading to unintended, unpredictable and hybrid outcomes.

A governance intervention introducing, for example, new socio-political structures and processes meets with local power structures, prevailing norms and expectations, and established socio-political relations, among villagers and local authorities. All these may be affected by various features of the intervention, intended or not, but they will also affect the intervention's performance and impact. The dynamics at the implementation interface thus influence how new features are contested and/or accommodated, and thereby what the impact will be on the power balance, on levels and chains of accountability, and on local political legitimacy. The same intervention will thus get different outcomes in different contexts. 
In this chapter, I discuss opportunities for and obstacles to a governance intervention to (re)create, or contribute to, local political legitimacy in rural Cambodia. Changes in local governance are illuminated in a specific sociopolitical, post-conflictsituation, and political proceedings as theintervention is implemented and takes root are elaborated regarding villagers' as well as local leaders' experiences, expectations and behaviour, regarding local power structures, and regarding perceived roles and responsibilities.

Thestudy ${ }^{2}$ was conducted severalyearsago, at an early stage of agovernance intervention and before a national decentralization reform. The findings concern the workings and early implications of a governance intervention on local socio-politics, and the discussion concerns opportunities and obstacles of such an intervention to increase local political legitimacy. Exploring the proceedings and implications of a governance intervention in the two villages Svay Ei and Kompong Loung, ${ }^{3}$ I describe and discuss how the intervention was perceived and accommodated by villagers and local authorities, and what potential impact it had on the legitimacy of the local political system and leaders. It should thus also be emphasized that rather than describing actual proceedings or assessing the local authorities' actual performance, focus is on conveying and illuminating villagers', and to a less extent officials', perceived experiences and expectations - which indeed affect actual performance and proceedings.

\section{CAMBODIA AND CARERE/SEILA - AN ILLUSTRATIVE CASE}

Post-conflict Cambodia illustrates how international development intervention has moved from quick-impact emergency and recovery towards longer-term development and reconstruction, including governance support.

Since the early or mid-1990s (and since the early 1980s on a much smaller scale) internationally funded development and reconstruction interventions in Cambodia have increased rapidly (CDC 1998). There has been a wide range of interventions by a wide range of actors, using different approaches and methods, and most aid resources have been used for traditional forms of development interventions, such as infrastructure, education and health care ( $c f$. Curtis 1998). At the village level, apart from material input, the interventions have often implied the setting up of new bodies such as rice bank committees, farmers' groups, maintenance groups, and new positions such as village health volunteers and village veterinarians. Development 
interventions have thus become part of the picture in Cambodia. As is common, however, interventions have tended to be concentrated on certain areas with numerous actors and activities in the same villages, while other parts of the country have remained largely untouched.

There have also been various forms of external influence on the political system. The immense UNTAC intervention in 1992-1993, leading up to multi-party national elections, has been followed by for example formulation of laws, development of policies, and support for further elections. As the country towards the end of the 1990s became increasingly peaceful, the importance of governance was emphasized by international donors, and some of them gradually and in different ways focused on the (re)construction of political institutions and structures, ultimately aimed at (re)creating political legitimacy at national as well as local levels. The most far-reaching governance intervention was the Seila programme CARERE2, ${ }^{4}$ which started in 1996 as an internationally designed and financed UNDP project, experimenting with different sorts of decentralization in a few provinces.

Cambodia is administratively divided into villages, communes, districts, provinces and the national level. In this study, as commonly in Cambodia, the term 'local authorities' is used for the village and commune levels. At the time of the research, there were 1,621 communes and sangkats (the urban equivalent) and 13,694 villages in the country. A commune usually consists of between eight and fifteen villages, and a village of between fifty and a couple of hundred households (though there are smaller as well as larger ones). At the time of the study, and until the commune elections in 2002, Commune and Village Chiefs were appointed by higher authorities, though there had in some places been symbolic elections between a few appointed candidates. ${ }^{5}$ Historically, the communes have not delivered any public services. From the early twentieth century, they dealt mainly with policing and security issues, and after the Khmer Rouge regime (19751979) the pre-occupation with security arrangements continued, along with population statistics, including recruitment of local defence militia and soldiers and issuing of birth, death and marriage certificates, for which the officials collected semi-formal fees (Rusten et al. 2004: 93, 142, 159).

Within the CARERE/Seila area, the prescribed roles and mandates of the local authorities gradually changed. ${ }^{6}$ The overall goal of CARERE2 was poverty alleviation (which was expected to contribute to peace) by improving the relations between the population and the authorities, and by making people participate in the development process (UNDP 1995). 
Among the main innovations were that the local authorities' security tasks were replaced by the provision of infrastructure and other services, and that certain responsibilities and procedures were more regulated.

At the village level, Village Development Committees (VDCs) ${ }^{7}$ were elected with a gender quota ${ }^{8}$ to guarantee the involvement and influence of women. The VDCs were set up along with other bodies and positions initiated by other development agencies, with the intended role to formulate a Village Development Plan (VDP) and co-ordinate development activities in a village. The purpose of electing the members was to create accountability and a sense of representation among the population. In practice, the VDC members came to perform tasks such as calling villagers to meetings, mobilizing them to contribute labour to development projects, collecting cash contributions and gathering population statistics.

The commune gradually came to play a key role in CARERE/Seila. An important component of its new mandate was to allocate resources for rural development. A Local Development Fund (LDF) was disbursed to all communes in the Seila area, for the Commune Development Committee (CDC; see footnote 7) to decide on its use after a participatory Local Planning Process (LPP). The LPP was led by facilitators employed by the CARERE project and by the Cambodian government. It involved village meetings where villagers were to discuss and decide on priority needs, and later to agree on the Village Development Plan suggested by the VDC. The assumption was that these meetings would create a feeling of involvement and ownership among villagers.

All VDPs in a commune would then be considered by the CDC, which also formulated a Commune Development Plan (CDP) and allocated the Local Development Fund for various projects. In addition to the LDF resources, villagers had to pay a local contribution in kind and/or cash, again with the intention to increase their feeling of involvement and ownership of a project. One of the main intentions with this planning and allocation process was to give the commune authorities a different role from before, turning them into development agents accountable to their constituency. Seeing the commune provide development resources was assumed to create positive expectations among the population, and to increase the commune's legitimacy. 


\section{CAMBODIA - A DIFFICULT CONTEXT FOR PARTICIPATORY INTERVENTIONS}

While an illustrative case, Cambodia also provides a difficult context for governance interventions aimed at (re)creating local political legitimacy. Socio-political structures and practices in rural Cambodia, as conventionally perceived, run against ideals of participatory decision-making and downward accountability. It is widely recognized that Cambodian society contains historical patterns of domination and repression ( $c f$. Mabbett and Chandler 1995; Martin 1994). The general perception is that of a scattered society, dominated by deep-rooted hierarchical social structures, patronclient relations, silent obedience, and a general lack of trust and cohesion among the population as well as towards the authorities (Vickery 1986; Thion 1993; Martin 1994; Ovesen et al. 1996; $c f$. Wolf 1969). Cambodia is also historically conceived of as a society of fear, physical violence and military presence (Bit 1991). During the 1980s - and in some places until the late 1990s - most of the rural population lived under the threat of Khmer Rouge insurgents, and also constantly risked being forcefully recruited by the authorities as soldiers or forced labour.

With such a socio-political climate, and expectations of instructions going downwards while loyalty and information move upwards, political legitimacy - as perceived in liberal democracies - with for example villagers actively holding local officials accountable, seems very distant. ${ }^{9}$ In addition, Cambodian society is often interpreted as very conservative, and not inclined for change ( $c f$. Thion 1993; Ledgerwood 1998). ${ }^{10}$

The view of local socio-politics as coloured by top-down approaches, distance, silence and compliance, and the assumption that this makes governance interventions difficult, are largely confirmed by empirical findings from 1999 and 2000, i.e. at an early stage of the governance intervention and before the decentralization reform. As will be seen, however, there are also examples of deviations from such relations and behaviour.

\section{Villagers' Perceptions of the Local Authorities}

The case studies show that villagers were neither clear about the local authorities' tasks and responsibilities, nor content with their performance. The villagers' main perception was that the authorities were there for those who had done something wrong, while others usually had no reason to see 
them. By far the most frequently mentioned role of the local authorities was to help solve disputes among villagers, which was done in quite an informal manner. The Svay Ei Village Chief claimed to be frequently consulted for conflict resolution, and told about the latest case:

Last Sunday some buffaloes had eaten rice plants on somebody's land. The landowner caught the buffaloes and brought them to me. I guarded them during the night. Then the buffalo owner came to get his buffaloes back. I called the landowner and discussed with both of them. The landowner demanded 50,000 riel (US\$13) [as compensation for the lost rice]. The buffalo owner wanted to pay only 10,000 riel, and I said 'please, increase it a little bit' ... At last they agreed on 20,000 riel.

Village Chief (m) October 1999

Villagers in Svay Ei, however, often complained that conflict resolution by the village authorities was expensive, inefficient and unfair. In this village, there was also a militiaman who was feared and disliked by villagers, but supported by the Commune Chief and therefore in many cases more powerful than the Village Chief. While the Village Chief was claimed to be frequently absent, and not interested in helping the villagers, the militiaman was not trusted and said to charge too much. Also, villagers claimed that the Village Chief and the militiaman favoured their relatives and friends and that the person who paid them most would win a conflict case, while someone who could not pay would not get any help. A landless widow's recent encounters with the two illustrate what others also claimed to have experienced:

As the woman's daughter was getting married, she went to inform the Village Chief. After walking the two or three kilometres to his house three times, just to find that he was not there, she gave up. Some time later, a neighbour accused her son-in-law of having stolen rice from his rice store. This time the woman went to see the militiaman who lived nearby. But he refused to help her if she did not first give him 5,000 riel (US\$1.3).

While villagers in Svay Ei therefore preferred to solve their conflicts among themselves, in Kompong Loung people more frequently consulted the village authorities. Here, the general perception was that assistance by the Village Chief was cheap and reasonably fair but slow, while the more educated Deputy Village Chief was fast, efficient but expensive. 
When it comes to authorities outside the village, the commune was in most villagers' perceptions blurred into the very widely used concept of 'higher levels' (thnaakleuk), filled by 'big people' (neak thom). Villagers stated that conflicts could be taken to the commune and district authorities, or even to court in the province or Phnom Penh. The idea of actually doing so, however, was remote for most villagers. Also, in Svay Ei people claimed that they were not allowed to bypass the Village Chief, which he confirmed, as did the Commune Chief. If somebody wanted to seek the help of commune authorities, for example to solve a conflict or to get a marriage certificate, she or he had to go through the Village Chief, who would then inform the Commune Chief - and charge for this service.

In Kompong Loung, people said that they felt free to go straight to the commune. They did this very rarely. Instead, they claimed, they always tried to solve conflicts within the village - some said because it was expensive to go further, some said because the Deputy Village Chief was eager to help in order to make money for himself. The widespread perception that 'the further you go, the more you will have to pay', is illustrated by the case of a motorbike accident when a young boy hit another boy from a different commune:

The injured boy's parents made a complaint, and all those involved were called to their commune. Vuen, ${ }^{11}$ who was a friend of the family of the boy who had been riding the bicycle, also went to help. It took them three days to come to an agreement.

The first day, the victim's side demanded 80,000 baht $^{12}$ (US\$2,100) in compensation. But Vuen said that was far too much, they would never be able to save that much money. They could only pay 10,000 baht. After all it was just a broken leg.

So, the victim's side reduced their claim to 65,000 baht, but Vuen still refused and asked them to go home and think about it.

The next claim was 25,000 baht, but the others maintained that they could not pay more than 10,000 . So, the victim's side tried with 15,000 baht.

- I again insisted on 10,000, Vuen says. And I added that if they didn't agree but wanted to bring the complaint to higher levels, like the district or the province, they would get even less, because we would have to spend a lot of money, and only pay them what remained.

When the victim's side heard that, they agreed to 10,000 baht.

- They were afraid that they would lose money. If they had gone to higher levels, they would have got only 2,000 or 3,000 baht. 
Obviously, this story, conveyed by one party of the conflict, does not provide objective facts of what happened, or what would have happened if the case had been taken further. What it does illustrate, however, is a common view and expectation of local conflict resolution.

Apart from the high costs involved, the study also points to a common perception of not understanding the procedures and therefore being easily cheated. This is illustrated by a young woman's story about her divorce:

Sophy married when she was 24 , but when she a year later had a miscarriage and could not work, she and her husband decided to divorce. The man went to inform the Village Chief, who asked them to come and see him the following day.

- Husband and wife came together on a bicycle, the Village Chief recalls. I could see that they didn't have a conflict. The problem was that their mothers didn't like each other.

So, the Village Chief tried to persuade the couple to stay together. But the man's mother did not accept that.

- She told the Village Chief to do anything he could to arrange a divorce, Sophy says. If he did, she would give him 20,000 riel (US\$5.3).

The Village Chief called them a second and a third time, when their mothers were also present. They still claimed that they wanted a divorce.

- I couldn't force them to stay together, so I agreed on a divorce, the Village Chief says.

Three years later, the man wanted to marry another woman. Sophy did not like the idea, but also claims that the village militiaman encouraged her to complain about her husband getting married to another woman, because he expected to get some benefits out of a conflict case.

Sophy went to the commune authorities and said that she and her husband were not properly divorced. For that, both of them needed to request a certificate at the commune, which she had not done. So, when the man came to the commune to get permission to get married, he did not get it but was asked to pay compensation to his previous wife.

- But he preferred to pay to the commune, Sophy says. He gave money to the Commune Chief for him to keep quiet. He gave money to the commune people, and they changed their minds.

- We asked him to pay her compensation to make her happy, the Commune Chief says. But he had no money, so we couldn't solve the case. If a couple don't agree, the commune cannot decide on a divorce. 
So, the commune authorities sent the case to the provincial court, and the two were called there three times. The first time, the man was asked to pay compensation to Sophy. He did not agree. The second time, Sophy was asked to agree on a proper divorce. She did not agree. The third time, the Village Chief was also called and his statement made the court decide in favour of the man.

Today the man is married to the other woman, and Sophy claims that he won the case because of his money and because she did not realise what happened.

- First the Village Chief said that I was right and 'you have to do like this'. The next time, he had changed his mind. I could have given him money too, and he would have changed his mind again. But I only brought a package of cigarettes when I went to see the Village Chief and the Commune Chief. And the court cheated me. They made me put my thumbprint on a paper. I thought it was in order to take the case to the court in Phnom Penh. But it was an agreement on divorce. It's difficult for me to understand, it's all in their hands.

Again, the story does not present any evidence of wrongdoing by the local authorities. What is presented is the story of a woman who did not want her previous husband to remarry. Still, the woman's experiences and perceptions illustrate that villagers thought of themselves as being at the mercy of authorities that were unjust and procedures that they did not understand and could not anticipate. The woman thought that she had done what she could and followed the advice she got, but was cheated by the authorities who were on her opponent's side. ${ }^{13}$

That villagers were not completely clear about the mandate, and not completely happy with the performance of the village authorities is not surprising. At the time of the study, the situation was unclear. There were no explicit, clearly announced mandates for what local officials could do, what they must do, or how they should do it. And the assistance commonly provided was inefficient and unfair. ${ }^{14}$

The findings indicate arbitrariness and informality in the role and conduct of local authorities. In the absence of clear and well-known regulations for what tasks to perform, and how to perform them, a Village Chief could largely choose to be as active or passive as he ${ }^{15}$ liked, and to run village affairs the way he found most appropriate, or most convenient. In many cases this made a Village Chief's role resemble that of running a 
family rather than doing a specified job or fulfilling an official's tasks. The arbitrariness points to the importance of leaders' individual personality, capacity and commitment for what kind of assistance villagers could expect. One Village Chief in the study was not very interested in helping the villagers, another would like to help but lacked the necessary skills. A militiaman was influential and eager to be involved, but feared by the villagers, and a Deputy Village Chief was capable but more concerned about personal benefits than the common good.

The case studies show that villagers felt distant from and unfamiliar with commune and higher level authorities. The thought of approaching them was remote and villagers claimed to expect that, if they did, it would be expensive and they would not get fair treatment. ${ }^{16}$ Apart from the problems of not understanding the procedures and of having to pay even more than at the village level, if villagers perceived the village authorities as uninterested or unreliable, there may not have been anywhere else to turn. This was so especially if the commune authorities supported the village authorities and if, as in Svay Ei, they did not allow villagers to come straight to them.

Along with villagers' lack of familiarity with and confidence in local authorities came a lack of positive expectations. Villagers had experienced or heard of local officials favouring their relatives and friends, of having to pay to get help, of the one who pays most getting the authorities' support, of officials not being accessible or interested. Unsurprisingly, with such widespread experiences (and/or rumours), villagers did not expect to receive any substantial assistance, efficient services or fair treatment.

Such experiences and expectations also affect villagers' behaviour in relation to the authorities. The dominating strategy was one of avoidance and compliance. Apart from trying to solve conflicts among themselves instead of consulting the authorities, people claimed to keep away as much as possible, to wait and see what 'higher levels' would say and do, and to do as they were told. An old woman in Svay Ei colourfully exemplified how villagers widely claimed to obey the authorities: 'Whatever they say, we just let them do it. If they tell me to go to prison, I'll go.' (Villager (f), October 1999).

Historically there have been good reasons for Cambodian villagers both to avoid the authorities and to do as they are told. Among the main tasks of the local authorities during the People's Republic of Kampuchea regime in the 1980s was to recruit a labour force and soldiers, and to collect money and materials, which rendered them feared and made villagers run away. ${ }^{17}$ 
Another main task was to distribute land, and at least in Svay Ei there were still bad feelings among villagers for claimed injustices in connection with this, which was another reason for the lack of trust and the perception that the authorities favour their relatives and friends.

However, while there used to be good reasons for keeping away, at the time of the study villagers' avoidance was not based on fear, but on indifference. ${ }^{18}$ As they did not expect anything good to come from the authorities, they perceived no reason to consult them, but chose to have as little as possible to do with them. This may have been a highly rational choice, given the authorities' main tasks and conduct. However, villagers may also claim to be more obedient than they actually were. If villagers ran away when the authorities were recruiting soldiers and a labour force, they could well still do so if they had found it worthwhile. The reason for compliance and indifference may have been that the authorities' conduct was less intrusive than before, and the perceived cost of obedience was lower.

Though villagers thus tended to deal with the local authorities in ways that were rational for them, the lack of clear mandates, the unfamiliarity, the perceived distance, inefficiency and injustice, and the ensuing lack of positive expectations, pose problems in terms of political legitimacy. Confirming the conventional view of Cambodian society, the study indicates widespread expectations among villagers (as well as among local authorities; see below) to receive instructions from above and provide obedience and information upwards, rather than being able to influence decisions at higher levels or demanding downward accountability. While the authorities, in the absence of an explicit and announced mandate, could extend their area of influence and act in quite an autocratic manner, villagers did not expect anything different. Such lack of positive expectations and widespread avoidance and compliance - whether based on fear or indifference - is clearly not conducive for downward accountability or other aspects of political legitimacy.

\section{Villagers' Perceptions of Development and Development Leadership}

At the time of the study, CARERE/Seila had been present in the two case study villages for a few years. ${ }^{19}$ Various development interventions by other agencies had been conducted in the villages before that, and certain development-related positions had been introduced. Apart from the elected Village Development Committees (VDCs), there were positions such as village health workers, village veterinarians, mental health workers and 
Red Cross volunteers. For such positions people were usually appointed by the development agency or the village authorities.

The study shows that development-related roles and responsibilities were not well known and understood by the people in Svay Ei and Kompong Loung. Almost no villagers were aware of the VDC as a group, or of its overall role. ${ }^{20}$ They did know a few individuals and their occasional specific tasks, such as calling for meetings, collecting money for a road, or maintaining a well. As regards the Local Planning Process, the CARERE and government facilitators were perceived as representatives of 'the organization' (angkar), and neither village meetings nor labour or cash contributions had created the intended sense of involvement and ownership.

The meetings, intended for villagers to discuss and decide on priority needs, were widely perceived as 'going to learn', i.e. to receive information or instructions, and not as instances for voicing opinions or making joint decisions. Villagers did not perceive themselves as deciding what kind of development project to implement, but rather perceived 'the organization' as telling them what was going to be provided, or possibly asking them for example whether they would like to have a road. ${ }^{21}$ Though the meetings were usually not felt to be very useful, but rather to interfere with more pressing tasks, villagers claimed that they always tried to attend. Rather than the result of compulsion, however, attending such meetings could be seen as a rational choice in order to receive the benefits that were expected to come with the intervention.

The local contribution in cash or kind, i.e. free labour, that was required from villagers in order to receive resources from the Local Development Fund (LDF), was usually tolerated by villagers without strong objections. Though, of course, people would have preferred to get the resources without having to contribute themselves, they tended to accept it as a rule of the game by one of the various agencies, arguing among themselves that 'We need to pay a little, in order to get the big funds'.

The commune's role in development activities was not well known and understood by villagers. Some commune officials (as well as district and provincial ones) had become slightly more familiar to villagers, since they got involved in development work and therefore visited the villages somewhat more often. Still, villagers widely claimed that people from 'higher levels' usually came only to see the Village Chief or the VDC leader. Neither the composition and mandate of the Commune Development Committee (CDC) nor its existence were known to any of the villagers we 
talked to. Neither were the existence and allocation of a Local Development Fund (LDF), and thus too the villagers' right to be represented on the CDC when the LDF was allocated. Accordingly, villagers did not perceive the commune authorities as main service providers.

The study also shows that not even CDC members (the VDC leaders and, in Kompong Loung, a women's representative) clearly knew the role of the CDC or how decisions should be made about the LDF allocation. The special women's representative in Kompong Loung had for several years held several other development positions, and was both well informed and committed to her tasks. When it came to the CDC and the LDF allocation, however, she was not clear.

Money comes from the province to the commune, and the commune decides how to allocate the money. The Commune Chief gives money to every project. The district also comes to make calculations. [...] Mostly they call the Village Chief and the leader [for the meeting where they do the calculation]. I attended once, but I didn't participate in the decisionmaking. (VDC- and CDC-member, Village health worker, Mental health leader (f), April 2000)

Needless to say, lack of clear knowledge and understanding among villagers and position-holders about new roles and responsibilities does not necessarily, or probably, reflect lack of capability or commitment. Rather, it may be caused by lack of appropriate information and involvement, as well as the difficult context discussed above in combination with the short time that the new structures had been in place. As with the role of the local authorities, it is not surprising that villagers were not clear about local development mandates and processes. At the time of the study, the role and responsibilities of VDCs were not clear. Neither was the radically changing prescribed role of the commune. Moreover, the study reveals a tendency for development positions sometimes to be established and staffed, but not filled with meaningful content and backed by resources, which obviously contributed to villagers' as well as position-holders' uncertainty about roles and responsibilities (see below).

Another problem was that the supposedly participatory planning process, leading to decisions about the allocation of the LDF, was often pushed through by the facilitators due to time constraints. Technical facilitators, who faced demands to complete their tasks, were - understandably - more concerned to meet time deadlines and show visible results to their superiors 
than to ground the process among the population, often because they had not got enough training to understand the underlying ideals and aims of popular participation. It thus happened that facilitators 'made' villagers ask for the kind of project that they found feasible, or filled in the Village Development Plan themselves in order to finalize the planning process within the time limit ( $c f$. Rusten et al. 2004).

Such a lack of clear understanding and such a lack of active involvement pose problems in terms of legitimacy and the democratic aim of the governance intervention. Though recently established development mandates and procedures may be formally defined, as long as villagers are not certain about their representatives' tasks (or even about the fact that they are their representatives) and about their own rights, they will not be able to hold anyone accountable or exercise their rights. Likewise, people who are not aware of the development role of the local authorities, or about the process of the LDF allocation, will not expect - or demand - accountability and influence.

As already stated, the lack of clarity of the new rural development structure may indicate that very much remained to be done in terms of information and education, which would not be surprising with such a big reform and such a short period of time. However, it could also be speculated that some villagers may have pretended to know less than they actually did, in order to minimize their own responsibilities. In Cambodia, it is difficult and demanding, sometimes risky, to exercise your rights and to hold others accountable. Especially for people who are not used to it, it may seem easier not to take on such responsibilities, and instead claim not to have - or not to know of - any ways of influencing events. ${ }^{22}$ Such possibly 'pretended' lack of awareness may be a highly rational strategy, considering the real or imagined dangers involved in knowing. However, if the lack of awareness is to some extent pretended, it is also crucial for the chances to (re)create political legitimacy through external intervention. If people are 'given' rights to vote, to hold leaders accountable, etc., without having fought for them, they may not be prepared - perhaps may not dare - to use and protect the rights.

Another difficulty is caused by the different approaches and varying demands on villagers between different agencies (and within agencies over time). As indicated, the study shows that villagers readily adjust to various opportunities and constraints that emerge. For example, they promptly learn that different agencies follow different procedures and rules, as 
regards for example villagers' involvement. Without distinguishing for example CARERE/Seila activities from those of other development agencies, villagers accepted and adjusted to the various demands attached to the expected benefits. They also tended to learn that one organization usually provides for example infrastructure, another some kind of training, and yet another agricultural inputs. They then tried to use available resources and opportunities as they found most appropriate, in a highly rational way following their own priorities and making the most out of what was being offered (cf. Scott 1976).

Food-for-work, for example, which was often used by the World Food Programme (WFP) but also sometimes in projects financed by the LDF, meant that villagers got paid in kind for working on a construction project in their village, with the idea that such active involvement would create a sense of ownership and responsibility for the construction. The study shows that villagers eagerly hoped for such projects, not because they needed a road or a canal, etc., but because they needed the income. After only a few cases of food-for-work projects, villagers came to include it in their livelihood strategies, counting on it as a recurrent source of income. In Kompong Loung, an offer of a canal project financed by the LDF had even been turned down by the villagers (though not unanimously), since it would not involve food-for-work, as it had the previous year. The following year, villagers were upset about a food-for-work project being delayed, because once it started people would be busy harvesting and only few could benefit from it.

However, even if villagers learnt to use interventions in ways that are rational for them, parallel programmes and various approaches used by other agencies might threaten the legitimacy of the governance intervention. Some agencies had more resources than the commune's development fund and, rather than channelling resources through the local authorities, they sometimes actively bypassed the commune. ${ }^{23}$ This made it difficult for people to perceive the commune as a main development agent, and they might prefer to turn to others for assistance, which would undermine the commune's possibly emerging development mandate and potentially increasing legitimacy.

Related to coexistence with richer agencies is the risk that a governance intervention, with the establishment of a political set-up with new mandates and responsibilities, undermines existing - more or less legitimate structures for service provision. In rural Cambodia, there have been various 
forms of community cooperation, including labour exchange, assistance to the poorest, pagoda committees and various village associations. The local pagodas have had a central role, not least in construction and maintenance work, with monks mobilizing resources and leading villagers for example to dig canals and repair roads ( $c f$. Rusten et al. 2004: 162). When designating such tasks for the local authorities - or to external development agencies - and sometimes paying villagers for the work, that role and source of legitimacy of the pagodas may be undermined. In Svay Ei, this was expressed in the quite frequent comment 'the monks have taken a break'.

\section{Intervention Impact on Local Power Structures}

The study shows that the introduction of new political structures and processes, and of new development resources, had a highly varying impact on power structures in the two case study villages.

In Kompong Loung, the establishment of a Village Development Committee (alongside an already existing rice bank, credit committees and various development-related positions) had led to a division of tasks between village authorities and development leadership. In this province the rule was that Village Chiefs and Deputies could not be VDC members, but that the Village Chief automatically was an 'adviser' to the VDC. Here, this had reduced the risk of autocratic exercise of power by the Village Chief and resulted in good co-operation between him and the VDC. This may, however, have been mainly due to the personalities involved, mainly the Village Chief who was genuinely relieved that others were doing the development-related work and took on tasks such as village statistics.

In Svay Ei, on the other hand, the establishment of a VDC (and a number of other development-related positions) and the inflow of external development funds at first glance appeared to have concentrated and increased the power of those in power. Here it had been beyond question that the Village Chief should also be the VDC leader. And despite his seemingly very limited commitment to development work, he had come to completely dominate the VDC, while other members were scarcely involved or even informed. The Village Chief, for example, sometimes went to CDC meetings and sometimes not. In neither case did he tell the other VDC members, which made them quite discouraged and dejected. Moreover, though the feared and unpopular militiaman was not a member of the VDC, he could largely control its work - backed up by the Commune Chief. The influence and involvement of other VDC members therefore 
clearly depended on their relation to these two powerful men. For example, as the women in the VDC did not enjoy the Village Chief's confidence, they did not get any responsible tasks.

No [a woman has never been in charge of the finances]. The finance person must have education and ability.

Village Chief, VDC leader (m), March 2000

The two cases illustrate that the impact of a governance intervention on local power structures, and ultimately on political legitimacy, is strongly influenced by local specifics. Development activities, and the resources and status that come with them, provide new sources of power, and how they come to be distributed depends on the socio-political climate and relations, power dynamics, personalities and relations to higher authorities.

The differing impacts on power structures were not clear cut, however. The ostensible balancing of power and division of tasks in Kompong Loung also reflected a reinforcement of existing power imbalances. Developmentrelated positions, within and outside of CARERE/Seila, were concentrated in the hands of a small group of mainly men, who all previously had had strong informal influence. Rather than extending power to people who did not already have it, the new development positions thus formalized and increased such informal influence. While a few already influential men had come to form a development elite, carrying out but also dominating development activities, others - not least women - were disregarded, and their capacity and commitment thus wasted. ${ }^{24}$ Both cases thus illustrate that those whose influence tended to increase were usually men. For the most part, men got the new development positions, and when a woman due to the gender quota did get a position, her influence was usually small.

The study also points to a potential risk that elections, instead of opening opportunities for marginalized groups and individuals, become mechanisms for formalizing and increasing the influence of the already influential, without making them any more accountable. It takes more than the right to vote for people to change their expectations of who should have a leadership position, and of what such a position implies. When introduced where there is no tradition of elections, it may not occur to most villagers to vote for others than those who already have some kind of position - be they village officials or informal leaders (and be they committed to other villagers' well-being or not). As a result, it will not be the poorest, the least educated and women who are elected, and thus their views and interests 
are not represented..$^{25}$ Also, if there is no habit or expectation of downward accountability, the idea of not re-electing someone who misbehaves may not immediately occur. Moreover, the fact that several women, due to gender quotas, got positions and the fact that the feared and disliked militiaman failed to be elected could be signs that elections can work as intended. However, as seen, women position-holders were often marginalized by male ones, and the militiaman retained his influence and managed to control the VDC's activities, both indicating that election results can partly be disregarded when running against prevailing informal power structures.

The apparent reinforcement of power in Svay Ei was somewhat ambiguous, though. In the short run, development positions and resources strengthened the two most influential people in the village - elected or not - without rendering them more accountable. The old habit of villagers not (openly) questioning or challenging the authorities meant that the influx of development resources directly increased these leaders' personal influence, which they largely used for the benefit of themselves and their relatives and friends. ${ }^{26}$ Perhaps paradoxically, however, this also made them more vulnerable. As their power abuse involved funds that should have been used for everybody's benefit, it became more apparent, and more relevant to people's livelihood, which added to the already existing dissatisfaction with their leadership, and led to open challenges (see below).

\section{Local Leaders' Perceptions of their Roles}

Turning to the local leaders' perceptions, officials as well as development position-holders in the study all claimed to have been reluctant to assume their positions. ${ }^{27}$ Among the local officials, the main reasons given were that the positions involved a heavy workload, but no remuneration or other advantages ${ }^{28}$ and that tasks, such as conflict resolution - due to the alleged inefficiency and unfairness discussed above - rendered them disliked. Therefore, the village officials stated, they would prefer to spend their time in their rice fields, with their grandchildren, at the pagoda, or to make a different career. ${ }^{29}$

As touched upon, local officials' room for manoeuvre largely depended on their relations with higher authorities, which may add to some officials' aversion. Without the backing, or at least the acceptance, of the commune authorities, village officials were quite weak. In Svay Ei, for example, there was a Deputy Village Chief who had no practical influence since the Commune Chief disliked him, while, as discussed, the same Commune Chief's 
favourite militiaman had a lot of power. The same kind of subordination was claimed by commune officials, perceiving no room of manoeuvre in their role. One Commune Chief was clearly discouraged when describing his relation to the district authorities:

The commune doesn't have the right to do anything. We live under the district. [...] I'm at a low level, and higher levels rarely pay attention to us. Commune Chief (m), February 2000. ${ }^{30}$

Among development position-holders, in Kompong Loung the reluctance was explained mainly by the workload involved, while in Svay Ei the main reason was a dejected feeling that they had no influence and that other villagers disliked and suspected them of using their positions for personal benefits. A VDC member for example complained that, if she was wearing a necklace, her neighbours would say that she could afford it thanks to her position.

The reluctance was also related to the lack of clarity about tasks and mandates, and the ensuing uncertainty of what was expected from the position holders. In both villages, people felt that one had to accept a position if elected or appointed, and there were numerous stories of people being put forward as candidates without their knowledge and of others leaving the village on election day in order not to be elected. ${ }^{31}$ A young man in Svay Ei was noticeably anxious when asked about his position as village health worker (peet tralab).

I only knew on the election day that my name was there [among the candidates]. I said to people that they shouldn't vote for me. I'm not knowledgeable. I didn't want to be a village health worker. But now, when people have voted for me, I have to do it. [...] The Village Chief asked me to do that work [collecting population data]. I don't know what it was for. When I went to every family, the house owners asked me 'What's the census for?' and I answered 'I don't know, I got this job from Him.' I had to use my own book, pen and energy, and I got nothing. Before, there was also a census in the village, but at that time, census people came to the village to do it themselves. [...] This time, the Village Chief asked me to do the census. [...] I only went for a meeting. There hasn't been any real training. The teacher said that when we've worked for a long time, we'll get a paper that confirms that we are peet tralab. Then, when I come with someone to the clinic or the hospital with that paper, they won't charge. [...] I haven't taken anyone 
to hospital. If someone came to ask me for help, I wouldn't know what to do, because I have no paper.

Again, of course this is not an objective description of what actually happened, but the claimed experiences of an individual villager who was anxious about not doing a good enough job. However, such experiences and such anxiousness reflect severe difficulties. Claimed reluctance, perceived compulsion and uncertainty about tasks and mandates do not form a good basis for political legitimacy, but are problematic for those who hold the positions as well as for those whom they are to represent and/or provide services for.

Not being clear about one's tasks and responsibilities obviously makes it difficult to do a good job, both in terms of specific assignments, and in terms of representing the villagers in relation to the authorities - which adds to uncertainty, to the fear of being disliked and blamed, and possibly to other villagers' dissatisfaction, or at least lack of positive expectations. Also, someone who is, or feels, forced to be a leader against her/his wish might not be a very committed or reliable one.

Such uncertainty and such reluctance may be genuinely felt, especially when people have been elected or appointed to positions that have not been filled with any meaningful content, and are not backed by any substantial resources. Apart from more or less marginalised VDC members and the village health worker above, who did not get what he perceived as appropriate training or certification, there were numerous appointed but inactive village veterinarians in both case study villages. Seeing people with a position not doing anything probably also adds to a perception among villagers that such positions are not important and that the holders cannot be expected to provide any services, or be held accountable. Moreover, when someone has taken on tasks that she or he does not fully understand, or performs only out of compulsion, it may be difficult for others to demand efficient services and accountability. This could, however, be partly why so many claim to not want their positions. Claiming to be unaware of their mandates could be a way for position holders to partly withdraw from their responsibilities. Local officials as well as development position holders may want to seem reluctant, in order that villagers will be grateful to them and not too demanding. 
The claimed powerlessness among local leaders also poses severe problems. In order to establish political legitimacy and accountability, the idea should be for lower levels of authority to represent the population in relation to higher levels. But if they are more dependent on - and therefore more loyal to - the level above them than to their constituency, ${ }^{32}$ it leaves the population with no entries into the system, i.e. no mechanisms for upward communication or for requiring accountability.

\section{DEVIATIONS FROM THE CONVENTIONAL VIEW OF CAMBODIAN SOCIO-POLITICS}

As we have seen, the study confirms much of the conventional view of Cambodian political culture. There were, however, also signs of deviations in terms of villagers' perceptions and practices, local officials' attitudes and conduct, and the relations between villagers and officials. These deviations were most visible in relation to a couple of controversial conflicts.

In Kompong Loung, a conflict had been building up over the years about access to some nearby fishing lakes as external businessmen had paid for the sole fishing right in an increasing number of lakes - and defended this right with armed guards. Though this deprived villagers of a crucial source of livelihood, until recently they had not dared to complain. 'If we try, they'll shoot us. They are big people.' (Villager (m), Nov 1999)

Something happened however, and there were heavy protests, including a number of petitions as well as a rally. Villagers from several villages put their thumbprints on petitions that were taken to local and provincial authorities, as well as to human rights organizations. When that did not work, hundreds of villagers jointly and openly disobeyed the ban on fishing, which made the authorities and businessmen, at least temporarily, withdraw the armed guards and tolerate the villagers' fishing.

Kompong Loung villagers widely claimed that the district authorities were responsible for excluding them from the fishing lakes, and some of them had asked for advice at the commune office about how to proceed with a complaint. The main initiatives, however, came from people in a nearby village who had relatives at the provincial court and therefore were reasonably familiar with the relevant procedures. The recent experience of protesting and partly succeeding had affected people's attitudes. Though villagers were far from confident that the businessmen's withdrawal would last, they believed that there would be renewed protests if necessary. 'In the 
past, people feared the authorities. Now, people know their rights, and they are brave enough to make complaints.' (Villager (m), Feb 2000)

In Svay Ei, as discussed, the introduction of development positions and resources initially reinforced the power of a few. However, it also increased their vulnerability. During the time of the field research, the general unhappiness with the village leadership augmented, and villagers got increasingly outspoken - to the research team as well as among themselves - about the misconduct by the two most powerful men in the village. Many villagers continued to believe that there was nothing they could do about it, since one of the two men was strongly supported by the Commune Chief. A few individuals, however, became increasingly determined to actually try to replace the village leadership, and some of them expressed optimism about the chances to succeed: 'It's democracy now. If villagers protest, they [the authorities] must listen' (Villager (m), March 2000).

After the last visit, the research team learned that these people had written a formal complaint, signed by most villagers, and taken it to the commune and district authorities. Despite the pattern of quiet avoidance and compliance, there were thus examples of villagers actively opposing 'big people' such as local officials and businessmen. In both cases, several factors combined to make villagers openly challenge leaders who abused their power or did not fulfil their responsibilities. The relevance to people's livelihood was important, as was the range of available options. Fishing was crucial for the survival of people in the fishing lake area, and as villagers were denied access to an increasing number of lakes they saw no alternative to disobeying the ban. 'You could just as well kill the villagers. Apart from rice farming, fishing is their most important income' (Deputy Village Chief (m), Feb 2000). In Svay Ei, though the village leaders' misconduct was not life-threatening in the same sense, it became more apparent and more relevant to people's livelihood, as it involved resources intended for the whole population's well-being. Villagers thus had more to gain from opposing the leaders' abuse.

However, neither threats to their livelihood nor apparent power abuse have as a rule made Cambodian villagers openly oppose the authorities. Rather, as Scott discusses in an adjacent context, if only a few villagers' livelihood is threatened at the same time, and if villagers fear that protesting would jeopardise their good relations with wealthier people on whom they depend, silence may be perceived as a better option than resistance (Scott 1985: 244ff). If, on the other hand, something acutely and simultaneously 
threatens the livelihood of a majority of the population, and if people feel that they do not have much to lose, protests are more likely (Scott 1985: 242ff). This was apparently the case regarding the fishing lakes in Kompong Loung, and to a lesser extent regarding the village leaders' abuse in Svay Ei.

The case studies also illustrate that active protests require knowledge, initiative and leadership. There must be individuals with courage and determination enough to motivate and mobilize others, and with enough comprehension of the procedures to know how to go ahead (in addition to relevant procedures actually existing). Regarding the fishing lakes protests, without the initiatives from a nearby village - where a few individuals were familiar enough with the provincial authorities to proceed and convincing enough to make others join - people in Kompong Loung would not have written any petitions or gone to any rally.

Initiative, motivation and leadership do not need to come ready-made from outside, however, but can be created and emerge from within. In Svay Ei, villagers increasingly talked among each other, and the unhappiness with the leaders' mismanagement thus got more outspoken and shared, which is a crucial component of poor people's means of opposition (Scott 1985: 44f). While villagers incited each other in their objections and discontent, alternative leaders emerged. VDC-members and a few others who felt dejected, increasingly discussed possible solutions, and villagers who did not trust the existing leadership increasingly turned to them for advice and hoped for their initiatives. These individuals were thus gradually accepted as leaders, and also gradually accepted that role, which strengthened them in their determination and enabled them to unite most of the villagers in protests against the village leadership.

The described cases of conflicts and protests give indications - though ambiguous - that perceptions of and expectations on the local authorities were different from those conventionally assumed. After having quietly accepted the village leaders' misconduct, in Svay Ei the idea occurred that it would be possible to challenge them. Meanwhile, in Kompong Loung villagers even asked the commune officials for advice.

This goes hand in hand with signs - though ambiguous - of deviations from conventionally assumed attitudes and views of themselves among local officials. Some expressed commitment to the population's well-being, though also dejection for being powerless in relation to higher authorities that did not share their commitment. ${ }^{33}$ The Commune Chief in the fishing 
lake area emphasized the commune's new 'development' tasks, and blamed the district and higher authorities when the commune was not able to fulfil them. 'Our job is to serve the villagers. But when the Ministry of Interior sells the lakes, what can we do?' (Commune Chief (m), Feb 2000). According to him, higher level authorities had accused the commune of supporting the villagers, which was supposedly exactly what the commune should do when their rights were being violated.

\section{DISCUSSION AND CONCLUSIONS}

As we have seen, at the time of the study, development interventions had become part of the picture in much of rural Cambodia. In the two case study villages, the governance programme CARERE/Seila, along with other development activities, had involved the election of VDCs and the introduction of other development positions, village meetings, local contribution in kind and cash, and a new commune mandate including the allocation of local development resources. This chapter deals with the implications of such interventions, ultimately aimed at (re)creating local political legitimacy.

The study shows that villagers in general adjusted, rationally accommodating and using various interventions as best they could. Much of the intentions with the governance intervention, however, had not been realised, at least not in the anticipated way. Village meetings were not perceived as instances for sharing of ideas and influencing decisions, local contribution had not created any strong sense of ownership and responsibility, VDC elections had not made villagers feel represented, LDF projects had not turned the commune into a major development agent, viable chains of downward accountability had not emerged. Rather, the study points to arbitrariness in local authorities' conduct, to perceived legal injustices and insecurity, to claimed reluctance, compulsion and uncertainty among position holders, and to claimed lack of clarity about roles, responsibilities and rights among villagers (or hesitation to use their rights). As has been emphasized throughout, these findings are matters of subjectively perceived experiences and expectations, and not of objective facts of actual proceedings. However, lived and shared perceptions affect people's behaviour and their relations to the authorities.

When aiming at local political legitimacy, these findings may seem discouraging, and are indeed problematic. Still, as noted, it is important 
to recognize the huge changes in practices and perceptions that the introduction of a new political set-up implies in rural Cambodia, and that it had at the time of the study been in place only for a short period. Though, at that time, very much remained for the overall intentions of the intervention to be realised, it was too early to say that it would fail in its socio-political ambitions.

As seen, there were signs of a socio-political climate and relations between villagers and local authorities different from the conventional view of the Cambodian society. There were villagers who talked vividly among themselves, who became determined to act and who had enough support to mobilize others. There were individual local officials who saw the population's socio-economic well-being as their main task. And there were villagers who challenged delinquent local officials, and succeeded, as well as villagers who sought the support of better behaving officials, and received it. Where those things happen may be where there are best chances for political legitimacy to occur and be consolidated. A question, then, is whether any potentially ongoing socio-political change in rural Cambodia is related to the governance intervention. And a subsequent question is whether political legitimacy can be introduced at all and upheld in places where people have not had to conquer it, i.e. through an externally designed intervention.

Even when various measures and activities do not have the intended results, introducing new structures and processes usually put old practices in a new light. Cemented relations and expectations may be stirred up. And stirring up old practices and introducing new features give villagers reasons to talk among themselves. Expressing and sharing views (whether about livelihood issues, discontent with a leader, etc.), then, may initiate a process of opposition, determination and mobilization on specific issues. And such experiences give rise to new expectations, among the population as well as the authorities - which may all partly and slowly contribute to more fundamental changes in socio-political structures. However, it will always be more or less impossible to determine to what extent such longterm changes are related to externally designed interventions of various kinds.

The clearest indications of active citizenship found in the study were not directly linked to the governance intervention. As we have seen, a couple of conflicts and ensuing protests in the case study villages provide vivid examples of highly motivated rural Cambodians who actively challenged 
injustices and claimed their rights. The experience of - or hearing about such open resistance both increased villagers' knowledge of and familiarity with available procedures, and made it easier to imagine a different strategy from silent compliance. With these recent experiences of different sorts of mobilization and protest, and partial success, villagers are more likely, next time a similar problem occurs, to approach the authorities to demand their rights, or to ask for assistance.

Something, on the other hand, that was clearly linked to the governance intervention was a change in the local authorities' tasks. A largely unregulated mandate dominated by security arrangements was supposedly superseded by better defined 'development' tasks, i.e. more livelihood and living standard related issues, along with the introduction of local development resources at the commune's disposal. The role and conduct of the commune authorities had at the time of the study not changed as fundamentally as intended by the governance intervention. Still, there were signs of emerging experiences and expectations. Though not a main impression, local officials were sometimes seen to connect with development projects, which has the potential of making them associated with welfare related issues. Any experience of the authorities that is more positive than what is conventionally expected may make villagers develop more positive expectations, and thus change their behaviour. If villagers see that the local authorities are involved in service provision, they may start to hope - maybe even demand - that it will happen again. And if it happens in a different village, they may start to hope - maybe even demand - that it will happen in theirs.

There were also signs of villagers being less indifferent to what the authorities did, possibly because the new tasks were more relevant to villagers' everyday well-being and concerns. The existence of public resources to be used for local needs has the potential of giving rise to positive experiences and expectations - and to objections if they are misused. As noted, abuse by the authorities will be more apparent and more relevant to villagers, misconduct could create stronger unhappiness and there would be more to gain from opposing such abuse. Again, positive experiences are crucial. If villagers experience, or hear about, committed and fair local officials, they may develop positive expectations and will have more reason to hold others accountable for their mismanagement, which could lead to more contact and demands, and less avoidance and compliance. 
Among local officials, too, new experiences (caused by the new mandate or not) may give rise to new attitudes and expectations. Service provision requires different qualities than previous tasks did, and those who get their positions now will have different expectations from those who held them since the 1980s, and will develop different experiences. To at least some extent they will get their positions with socio-economic activities in mind, and though this is a long-term and uncertain trend, interested, committed and development-oriented local authorities will be more inclined to support and protect villagers' socio-economic interests when others threaten them, which could also make villagers actively seek their support, and further encourage their commitment. Accordingly, local officials will also have more reason to continuously try to gain political legitimacy among the population.

A potentially major obstacle, found in the study, when aiming to (re)create local authorities' political legitimacy by turning them into major service providers is the presence of other development actors. As noted, in rural Cambodia there are various actors, development agencies as well as political parties, that have more resources than the local authorities, that use different methods, and that sometimes actively bypass the authorities. Villagers may thus experience significant development investments by others than the authorities, with no demands attached to them such as attending meetings and paying local contributions, and which provide quicker and more substantial input. This counteracts the intention to make villagers perceive the local authorities as main development actors and service providers. Rather, in comparison to wealthier agencies with different approaches, the local authorities may be perceived as not responding adequately to villagers' needs and as putting excessive demands on villagers. As a result, people may turn to development actors that have more resources, act more quickly, and require less from villagers, a process which obviously undermines the local authorities' emerging development role and increasing political legitimacy ( $c f$. Rusten et al. 2004: 59, 117, 126ff, 160f).

Just as it is difficult or impossible to determine the causes of various sorts of societal change, it is difficult or impossible to predict the immediate and long-term impact of an externally designed intervention. With governance interventions, along with other development interventions, as significant features in much of rural Cambodia, however, they are inevitably part of ongoing socio-political change. 
As illustrated by the case studies, the introduction of externally designed structures and processes should not always be expected to have the intended results. Local conditions and dynamics at the local interface will make the outcomes unpredictable, and the same intervention will get different outcomes in different places. Local political legitimacy is not easily makeable and, as seen, there are strong obstacles to it in rural Cambodia. These include the heritage of a political climate non-conducive to popular participation and downward accountability, and the existence of a large number of influential development actors using different approaches and channels from the local authorities. However, the study also points to opportunities for contributing to increased legitimacy. Introducing a new role and mandate for the local authorities and creating new experiences for villagers as well as officials have the potential of giving rise to new expectations. Partly as the result of external intervention, old practices may be stirred up and new processes may be set in motion. Change will thus not be as controlled as seemingly assumed in interventionist thinking. Instead, it may become locally grounded, though more or less inspired by external intervention.

\section{NOTES}

1 'Intervention' is not necessarily conducted by international actors, but can also be done by local agencies or the national state. Though initially designed and driven by international actors, governance reforms have been increasingly adopted by the Cambodian government (Kato et al. 2000; Smoke 2000; Charny 1999).

2 The chapter is based on ethnographic research in two villages in lowland Cambodia during 1999 and 2000 (Hasselskog 2000). The research team consisted of the writer of this chapter, an expatriate PhD student who did the study as an integrated part of a long-term assignment with the UNDP, a Cambodian employee of the Ministry of Rural Development (MRD) and a Cambodian former Red Cross employee, all women. The team spent about four months in the two villages, conducting semi-structured interviews with villagers and village leaders, along with observations and frequent informal encounters. Several hundred interviews were conducted, in many cases with the same people several times, sometimes individually, sometimes with family members and neighbours present and participating. Focus group discussions were also conducted, mainly for presentation of and feedback on preliminary findings. At the commune level, officials were interviewed on several occasions, while in the provinces, government staff as well as UNDP/CARERE staff and managers were interviewed.

3 The names of the villages have been changed.

4 The CARERE project in itself illustrates the move from quick impact towards longerterm development with focus on governance. During the first phase of the project (1992- 
1995) - Cambodia Resettlement and Reintegration - emphasis was on emergencytype interventions, such as provision of basic infrastructure, in communities where returning refugees settled. CARERE2 (1996-2000) - Cambodia Area Rehabilitation and Regeneration - gradually shifted approach and turned into a policy experiment in decentralized planning, financing and management of rural development.

5 In one of the case study villages, the Deputy Village Chief claimed that he had received most votes in such an election, but since he was younger than the other candidate, he had chosen to be Deputy instead of Village Chief.

6 CARERE/Seila gradually expanded and came to largely influence the national decentralization reform, including elections of commune councils in early 2002 (i.e. after the time of this study) (Cambodia Royal Government 2000a; Cambodia Royal Government 2000b).

7 In 1999, the Cambodian government decided on a policy of a Rural Development Structure (RDS) that had already been partly operationalized in the Seila area. Rural development committees were to be set up at village, commune and province levels. The Village Development Committees (VDCs) were elected by villagers, while the Commune Development Committees (CDCs) would consist of commune officials and village representatives who were to meet at regular meetings plus when the Local Development Fund (LDF) was allocated (Cambodia Ministry of Rural Development 1999).

8 Two out of five or three out of seven VDC members should be women. In the 2002 commune elections there were no gender quotas, and 8 per cent of the elected councillors were women (Rusten et al. 2004: 97).

9 Caroline Hughes (2003) and Rusten et al. (2004: 46f) are among those who have discussed what happens in the Cambodian context as an emerging liberal democratic culture meets a patronage culture, including for example how new resources can be captured by local power holders.

10 Some historians, though, tend to argue that change is possible even in the 'conservative' Cambodian society (Martin 1994). Öjendal and Kim also argue against the view of Cambodian political culture as unchanging and unchangeable (2006).

11 Pseudonyms are used when naming people in the study.

12 In this part of Cambodia, the Thai currency is widely used.

13 It may be worth pointing out that, though such perceptions are indeed problematic, they may not be completely different from those of some people in liberal democracies.

14 As Rusten et al. show, some years after this study, after the national decentralization reform, the regulations of the commune were still not well known (2004: 125).

15 The overwhelming majority of Village Chiefs in Cambodia are men.

16 This pattern is confirmed for example by Mansfield and MacLeod, who state that although in principle free to hold Commune Councillors accountable, in practice villagers are unlikely to approach them (2004: 23). McAndrew also finds that the Commune Councils have largely failed to establish a rapport with ordinary villagers (2004: 4, 21).

17 Öjendal and Kim also point out that there were good reasons why the local authorities during the PRK regime and into the 1990s were not popular among the rural population (2006). 
18 This is confirmed by Öjendal's and Kim's study from a few years after the commune elections, indicating a lack of fear, or at least a radical decrease in the level of it, among villagers in relation to the local authorities (ibid.).

19 Both Svay Ei and Kompong Loung were included in CARERE2 from its start in 1996.

20 These findings are confirmed by the later study by Rusten et al., pointing to a lot of confusion about roles and responsibilities of VDCs and Village Chiefs, and to villagers recognising only the Village Chief (2004: 125). Mansfield and MacLeod in their study note that only those VDCs are regularly active that are supported by development agencies (2004: 22).

21 At the time of the study there was a heavy bias towards using the Local Development Fund for small scale infrastructure projects. This was clearly what the technical facilitators expected and had the skills for, and therefore promoted - which by villagers could be interpreted as 'they asked if we wanted a road'. A similar bias for small, basic infrastructure projects, encouraged by technical support staff, is found by Rusten et al. Their study shows that the nature of commune development projects had not changed during the last five years, and did not vary much between communes. Villagers were found to perceive development as something involving physical structures, and there were three categories of projects: roads, schools and water supply sources (2004: 91, 145f).

22 Again, this may not be very different from the situation in many liberal democracies.

23 These agencies include international and local NGOs as well as political parties ( $c f$. Rusten et al. 2004: 135f). Öjendal and Kim note that, after the commune reform, some NGOs make a point of not 'having to' seek the permission of the commune authorities any more (2006). According to McAndrew, mutual recognition and co-operation are emerging between NGOs and local government. Still, due to the size of NGO programmes along with remaining suspicions about working with the government, NGOs could disable efforts by the Commune Councils $(2004: 8,22)$.

24 The studies by Rusten et al. (2004: 7, 119ff) and by Öjendal and Kim (2006) indicate a similar tendency in the Commune Councils. Rusten et al. show that it is difficult to get women to run for the commune elections, while Öjendal and Kim show that female councillors tend to attend council meetings less than male ones, mainly due to family duties. Both studies also illustrate that, once elected, female councillors are frustrated by the lack of influence and not keen to remain in their positions.

25 Again, this may not be very different from the situation in many liberal democracies.

26 Similarly, McAndrew, referring to Ayers (2001), notes that local elites tend to dominate the political system and capture the benefits derived from it (2004: 8). Also, Mansfield and MacLeod, in their study of the Commune Councils, find that people who belong to the majority party in the Council receive emergency assistance first and most frequently, and that councillors from one party are unlikely to help someone from another party (2004: 24).

27 Among development position-holders, however, at least in Svay Ei, there was also competition for going to meetings and training when there was a daily subsistence allowance (DSA), which created conflicts and further complaints about the village authorities favouring themselves and their friends when appointing people for such activities. (It may be worth pointing out that, for poor breadwinners, trying to get 
access to extra incomes such as DSA could be seen as highly rational and responsible behaviour, rather than a sign of greed.)

28 At the time of the study, Village Chiefs received a monthly supplement from the state of 10,000 riel (2.5 US dollars), though the payment was often delayed by months or even years. Deputy Village Chiefs did not get any supplement, if the Village Chief did not share his.

29 Again, Rusten et al. come up with similar findings regarding Commune Councillors, many of whom express reluctance about running for the next election. The reasons given are that they spend too much time without enough compensation, are unclear about their roles and responsibilities, and that there are high expectations on them that they are unable to meet. They also tend to lack self-confidence and rely on past experience, looking upwards for instructions and expecting upward accountability (2004: 106ff, 135).

30 Similarly, Mansfield and MacLeod, in their study a few years later, note that Commune Councillors are only gradually learning to approach higher-level officials and pressure them to be accountable (2004: 23).

31 In their study, Mansfield and MacLeod found Commune Councillors who could not explain how they had been selected as candidates (2004: 24).

32 Again this is confirmed by later findings by Rusten et al. As they point out, rather than being accountable to the population/constituency, Village Chiefs and Clerks are accountable to the central government, and Commune Councillors are accountable to political parties (Rusten et al. 2004: 200). McAndrew also notes that party loyalties have undermined the effectiveness of some Commune Councils (2004: 4).

33 Öjendal and Kim in their study also find clear signs of attitudes and working methods among Commune Councillors different from those previously found among local officials (2006).

\section{REFERENCES}

Ayers, David (2001) Decentralisation: A Review of the Literature. Phnom Penh: CCSP.

Bernander, Bernt, Joel Charny; Marita Eastmond; Claes Lindahl and Joakim Öjendal (1995) Facing a Complex Emergency. An Evaluation of Swedish Support to Emergency Aid to Cambodia. Stockholm: Sida.

Blaut, J. M. (1993) The Colonizer's Model of the World. Geographical Diffusionism and Eurocentric History. New York: The Guilford Press.

Brown, Frederick Z. and David G. Timberman (eds) (1998) Cambodia and the International Community. The Quest for Peace, Development, and Democracy. New York: Asia Society.

Cambodia Ministry of Rural Development (1999) 'Circular of Guidance for the Implementation of the Royal Government Decision No. 02 SorSor Ror of 11 January 1999 on the Establishment of the Provincial Rural Development Committee, Phnom Penh.'

Cambodia Royal Government (2000a) ‘Seila Programme 2001-2005’, Phnom Penh. 
- - (2000b) 'Draft Law on Commune Administration', Phnom Penh.

CDC (1998) 'Council for the Development of Cambodia. Development Cooperation Report (1997/1998)', Main Report, Phnom Penh.

Chandler, David (1998) 'The Burden of Cambodia's Past'. In Brown, Frederick Z. and David G. Timberman, Cambodia and the International Community. The Quest for Peace, Development, and Democracy. New York: Asia Society.

Charny, Joel R. (1999) 'Issues for Decentralized Planning and Financing of Rural Development in Cambodia', paper presented at the Workshop on Decentralized Planning and Financing of Rural Development in Asia, held on 19-22 January at AIT in Bangkok, Thailand.

Crewe, Emma and Elizabeth Harrison (1998) Whose Development? An Ethnography of Aid. London: Zed Books.

Curtis, Grant (1990) Cambodia: A Country Profile. Report prepared for the Swedish International Development Authority. Stockholm: Swedish International Development Authority.

- - (1998) Cambodia Reborn? The Transition to Democracy and Development. Geneva: UNRISD.

Findlay, Trevor (1995) Cambodia. The Legacy and Lessons of UNTAC. Oxford: Oxford University Press.

Gottesman, Evan (2003) Cambodia after the Khmer Rouge: Inside the Politics of Nation Building. London: Yale University Press.

Hasselskog, Malin (2000) Local Governance in Transition. Villagers' Perceptions and Seila's Impact. Phnom Penh: UNDP/CARERE.

Heder, Stephen (2005) 'Hun Sen's Consolidation. Death or Beginning of Reform?' Southeast Asian Affairs, pp. 115-117.

Hettne, Björn (2005) 'Discourses on Development'. In Haynes, Jeffrey (ed.), Palgrave Advances in Development Studies. Palgrave: New York.

Horng Vuthy, Pak Kimchoeun, Ann Sovatha and Ngo Ngoun Theary (2005) 'Decentralisation and Deconcentration Reforms in Cambodia: An Early Review'. In Murshid, K. A. S. and Brett M. Ballard (eds), Annual Development Review 2004-05. Phnom Penh: CDRI.

Hughes, Caroline (2003) The Political Economy of Cambodia's Transition, 1991-2001. London: Routledge.

Kao Kim Horn (1998) 'Cambodia and the International Community: The Road Ahead'. In Brown, Frederick Z. and David G. Timberman (eds), Cambodia and the International Community. The Quest for Peace, Development, and Democracy. New York: Asia Society.

Kato, Toshiyasu, Jeffrey A. Kaplan, Chan Sophal and Real Sopheap (2000) Cambodia: Enhancing Governance for Sustainable Development. Manila: Asian Development Bank. 
Ledgerwood, Judy (1998) 'Rural Development in Cambodia: The View from the Village'. In Brown, Frederick Z. and David G. Timberman (eds), Cambodia and the International Community. New York: Asia Society.

Loh Kok Wah, Francis and Joakim Öjendal (eds) (2005) Southeast Asian Responses to Globalization. Reconstructing Governance and Deepening Democracy. Copenhagen: NIAS Press.

Long, Norman (2001) Development Sociology. Actor Perspectives. London: Routledge.

Mabbett, Ian and David Chandler (1995) The Khmers. New York: Oxford University Press.

Mansfield, Christine and Kurt MacLeod (2004) Commune Council and Civil Society: Promoting Decentralisation through Partnership. Phnom Penh: PACT.

Martin, Marie Alexandrine (1994) Cambodia: A Shattered Society. Berkeley: University of California Press.

McAndrew, John (2004) Experiences of Commune Councils in Promoting Participatory Local Governance. Phnom Penh: CCC.

Murshid, K. A. S. (2005) 'Introduction. Critical Development Issues'. In Murshid, K. A. S. and Brett M. Ballard (eds), Annual Development Review 2004-05. Phnom Penh: CDRI.

Murshid, K. A. S. and Brett M. Ballard (eds) (2005) Annual Development Review 2004-05. Phnom Penh: CDRI.

Olivier de Sardan, Jean-Pierre (2005) Anthropology and Development. Understanding Contemporary Social Change. London: Zed Books.

Öjendal, Joakim (2005) 'A New Local State in Cambodia? Decentralization as a Political Commodity'. In Loh Kok Wah, Francis and Joakim Öjendal (eds), Southeast Asian Responses to Globalization. Reconstructing Governance and Deepening Democracy. Copenhagen: NIAS Press.

Öjendal, Joakim and Kim Sedara (2006) 'Korob, kaud, klach - In Search of Agency in Rural Cambodia'. Journal of Southeast Asian Studies 37 (3).

Ovesen, Jan, Ing-Britt Trankell and Joakim Öjendal (1996) When Every Household is an Island - Social Organization and Power Structures in Rural Cambodia. Uppsala: Research Reports in Cultural Anthropology.

Roberts, David W. (2001) Political Transition in Cambodia 1991-99. Power, Elitism and Democracy. Richmond: Curzon Press.

Rusten, Caroline, Kim Sedara, Eng Netra and Pak Kimchoeun (2004) The Challenges of the Decentralisation Design in Cambodia. Phnom Penh: CDRI.

Scott, James C. (1976) The Moral Economy of the Peasant. Rebellion and Subsistence in Southeast Asia. New Haven and London: Yale University Press.

- - (1985) Weapons of the Weak. Everyday Forms of Peasant Resistance. London: Yale University Press.

Seanglim, Bit (1991) The Warrior Heritage: A Psychological Perspective of Cambodian Trauma. Le Cerrito: Seanglim Bit. 
Smoke, Paul (2000) 'Strategic Fiscal Decentralization in Developing Countries: Learning from Recent Innovations'. In Shahid Yusuf, Weiping Wu and Simon Evenett (eds), Local Dynamics in an Era of Globalization. 21st Century Catalysts for Development. New York: Oxford University Press/World Bank.

St. John, Ronald Bruce (2005) 'Democracy in Cambodia - One Decade, US\$5 Billion Later: What Went Wrong?' Contemporary Southeast Asia 27 (3), pp. 406-428.

Thion, Serge (1993) Watching Cambodia. Bangkok: White Lotus.

UNDP (1995) CMB/95/011/A/01/31; CMB/95/A11/A/XX/31, CARERE2 - Cambodian Area Rehabilitation and Regeneration Project. Phnom Penh: UNDP.

UNTAC (1992) United Nations Transitional Authority in Cambodia. United Nations Secretary-General's Consolidated Appeal for Cambodia's Immediate Needs and National Rehabilitation. Phnom Penh: UNCTAD.

Vickery, Michael (1986) Kampuchea: Politics, Economics and Society. London: Pinter; Boulder: Rienner.

Wescott, Clay G. (ed.) (2001) Key Governance Issues in Cambodia, Lao PDR, Thailand and Viet Nam. Manila: Asian Development Bank.

Wolf, Eric (1969) Peasants. New Jersey: Prentice Hall Inc. 


\title{
Chapter 8
}

\section{Cambodian Religion since 1989}

\author{
John Marston
}

It is not surprising that the political and economic changes which took place in Cambodia at the end of the 1980s and the beginning of the 1990s would affect religion, although it is still not easy to see clearly the overall trajectory of the transformations or to understand clearly why specific developments occurred. In part, this is because the processes are still very much playing themselves out.

At the most superficial level, what took place claimed to be a return to structures which existed prior to the Pol Pot period and the restrictions on religion maintained under the socialist government of the 1980s. Certainly, the imperfect memories of pre-war practices affected the development of religion in the country after the mission of the United Nations Transitional Authority in Cambodia (UNTAC). In another sense, it is more accurate to see the developments as something without precedent in the country.

The transformation which occurred might be described in terms of the increasing importance of religion in Cambodia. Buddhism has, among other things, re-established its links to the monarchy and is once again the state religion. Nevertheless, the fitful, ad hoc character of much of what we observe leaves one wondering what religious institutions, if any, are on solid grounds. As we will see, religion has responded creatively to a number of emerging institutions, either to support them or to challenge them. Likewise, new social institutions have used the institutions and conceptual systems of religion, attempting to adapt them to their own purposes and perhaps at the same time reshaping them. All this applies to the new institutions of 'civil society' typical of this period (the framework most commonly addressed in previous publications) and to the promotion of civil society by international institutions promoting democratization. But it also applies to 
such new patterns as the financial remittances from overseas Cambodians, new roles of the media, the emergence of a particularly Cambodian pattern of party politics, and the development of new patterns of patron-clientism.

This chapter includes a section on developments in Cambodian law and governmental administration dealing with religion since 1989, followed by three sections dealing with new movements: NGO movements linked to Buddhism, dissident monks, and two emerging leaders who happened to have both been radio preachers. My intention in describing these movements is to show them as challenges to state legitimacy. The first section deals with emerging civil society, forms of organization which in the socialist period had not existed, and which by their appearance implicitly challenged traditional 'state' bodies. These are very much the type of institutions promoted in the immediate aftermath of UNTAC, internationally funded, and conceived as a logical counterpart to liberal democracy. I find that a few new organizations found a niche for themselves, but in a religious context the NGO movement does not seem to be growing. The second section is about direct challenges to the legitimacy of the state by monks. We find scattered examples of this, but again very limited momentum as a movement. The third section is about two religious figures who acquired grass-roots support at what seems to me a deeper level than the other organizations and movements I have described. I explore some of the complexity of their situation in that they have, I argue, in practice been very cooperative with the ruling party (and got significant donations from politicians of the dominant party), but have nevertheless somehow acquired a symbolic role which is subversive of the authority of the state. This shows, I think, some of the ambiguities of the relationship between religion and social legitimacy in the highly politicized Cambodian context.

\section{THE STATE FRAMEWORK}

In 1989 constitutional reform began to reverse some of the restrictions on religious practice which had existed throughout the People's Republic of Kampuchea period. During this period, there had been no Ministry of Religion, and Buddhism (as well as other religions, such as Islam) had been administered through the Front. That is to say, it was considered a mass organization structurally parallel to labour unions and the women's association. The highest ranking Buddhist monks were in some sense under the administrative direction of Front officials and subject to their 
direction - which is to say, ultimately, to the direction of the Party. Wat lay committees had great power over the direction of the wat. Donations to wats were not to be used exclusively for the wats themselves; a portion was to be passed on for larger projects of service to the community at large. Perhaps most importantly, young men were not allowed to enter the monkhood, primarly because of the fear that they would use the monkhood as a means of escaping military service. (However, in rural areas, many young men were able to ignore this restriction and become novices or fullfledged monks.)

Early during the PRK period the decision was made to have only one monastic order in Cambodia. While it was not initially called Mahanikay, most observers see it as representing a continuation of the Mahanikay tradition much more than the Thammayut. Some early attempts to restore the Thammayut order were suppressed. In 1980 a group of Theravada monks came from Vietnam to re-establish the monastic lineage, ordaining seven Cambodian monks, including the current Mahanikay patriarch, Tep Vong, and from that time on only monks who had been ordained within that lineage were recognized.

While these restrictions were profound, one should not forget that this was a period of the revival of Buddhism after it had been virtually eliminated by the Pol Pot regime. Despite all these restrictions, it was a period of the rebuilding and restoration of wats, and a return to the country of basic ritual practices that have proved to be very deeply seated in the culture. The socialist government did not particularly value religion, but it recognized that it had a place in society and was willing for it to reaffirm itself as a social institution.

The changes that were instituted in 1989 were part of a larger package of constitutional changes that included the change of the country's name to State of Cambodia. The changes backed away somewhat from the socialist stance of the 1980s, taking the first steps toward the restoration of private property and the basic mechanisms of a free-market system. The reforms ultimately related to peace negotiations which were taking place at the same time with the representatives of the armed resistance movements on the border. With the withdrawal of Vietnamese troops, the reforms represented the country as amenable to basic changes of the kind that would make a settlement with resistance factions feasible.

At the time Buddhism was declared the official religion and mechanisms were put into place to allow young men to be ordained again. (There was 
initially to be a careful screening process, and the young men had to sign an agreement that after three years as a monk they would be available for three years of military service. Subsequent political developments before the first three years were up meant that none of these young men were actually obliged to enter military service.) An important Buddha relic, closely associated with Sihanouk, which could be described as a cosmological symbol of the kingdom, was returned ceremonially to its customary place in a stupa in front of the railway station.

In the course of the next three years, with the implementation of the Paris Agreements and a massive UN mission, there was further restoration of religious institutions which had existed prior to the war. With former king Norodom Sihanouk's return the Thammayut order was re-established in the country in 1991, and the highest-ranking monks were once again given royal titles. Eventually, with the restoration of the monarchy, the motto 'Nation, Religion, and King' was adopted by the country, a slight variation on one used before 1970, 'Nation, Religion, and Throne.'

In 1992, a Ministry of Religion was established, meaning that state administration of religion was no longer under the Front. With the mushrooming numbers of young monks, the system of monastic education was re-established, first in the form of primary education in the Pali language for monks, and then expanding to secondary and tertiary institutions. The Buddhist Institute was also re-established in 1992. Pre-1975 religious books were widely reprinted (some with the help of Japanese funding) and new books began to be written and published.

\section{BUDDHISM AND CIVIL SOCIETY}

Of course, international organizations and international NGOs had operated in Cambodia throughout the 1980s, even though there was no legal mechanism by which local NGOs could be formed. (Many of these international NGOs had religious affiliations, although these were downplayed during the socialist period.) There were many more IOs and NGOs operating in the refugee camps on the Thai border, where their existence provided a mechanism for the provision of aid. There, it should be noted, the religious focus of organizations could be more overt. There also could be, to a fairly limited degree, contact between the Buddhist institutional frameworks as practised in the camps and those of Thai Buddhism, including such movements within Thai Buddhism as 
the Engaged Buddhism of Sulak Suvaraksa or the philosophically very different movements associated with Chittapawan Buddhist College, which nevertheless also stressed a link between Buddhism and social action.

Once the Paris Agreements were signed there was a massive, rapid flourishing of NGOs and IOs in Cambodia, both international NGOs and local ones. This had to do with many things: international recognition of the legitimacy of the emerging government in Phnom Penh, flows of money into the country with the hope of shaping the transitional society, and the anticipation of legal frameworks which would permit NGOs. The term 'civil society', of course, has larger implications than the existence of NGOs, although in Cambodia the terms are largely used interchangeably. My interest here is in non-state organizations, outside the formal structure of religion, which are in some ways identified both with Buddhism and with social agendas.

The emergence of 'civil society' has been addressed by a number of scholars, notably C. Hughes. Perhaps the main point to be made is that emerging NGOs are generally viewed favourably by Western observers, as an alternative to the preponderant state role under socialism, as mechanisms to address grass-roots problems, and as a means of giving voice to those who would question state policies and authority. On the other hand, as Hughes, Navuth and others have shown, they are in practice not always as totally grass-roots in orientation as they might ideally be; they are nearly always dependent on foreign aid and thus (often) tend to steer in the direction of the latest foreign agendas. They often depend on the charismatic leadership of Cambodians with the ability to interface with both Cambodians and the international organizations they rely on for funding; the complex identities of these leaders do not necessarily serve grass roots needs.

As far as I have been able to determine, only a relatively small number of local NGOs have an explicitly Buddhist agenda, although a larger number make vague reference to Buddhist values. By far the most famous of the NGO movements which emerged at this time was the Dhammayietra peace marches closely associated with the Cambodian monk Maha Ghosananda. In fact, at the time of the UN mission to Cambodia in 1992-3, it was for many a highly emotional symbol of the whole peace process and the promise of political reconciliation in Cambodia, and was extensively covered by the international press. Like the other NGOs associated with Cambodian Buddhism, it has a very positive international image and for very good reasons. 
Various points should be emphasized, some of which to a degree undercut the force of the movement. The movement originated in refugee camps on the Thai border, and although it came to be seen as a very Cambodian movement, and one associated with a single Cambodian religious leader, it was originally the brainchild of a group of people working in the border camps, many of whom were non-Cambodian. Poethig (2004) has emphasized the transnational nature of the movement. It would eventually incorporate as a local Cambodian NGO, and yet in vision, and to a degree in funding, its international links were extremely important. The movement genuinely did appeal to Cambodians at the grassroots level, as well as having a high international profile. Its charismatic leader, Maha Ghosananda, played a central role in all of this. However, when he grew sick and could no longer play an active role, the movement apparently lost much momentum. The Dhammayietra marches continue to take place every year, but are smaller, receive little public attention, no longer seem to be on the cutting edge of Cambodian Buddhism, and perhaps are no longer capable, in the way the original marches somehow did, of transforming Cambodian Buddhism.

Like other NGO movements, it very much has had a social agenda and could be seen in some ways as challenging state institutions. (The very fact that it is organized as an NGO means it chooses institutional frameworks that could not have existed prior to UNTAC.) Part of the drama of the marches was this sense that they were challenging outworn institutions. On the other hand, its idealistic goals were easily reconciled with those of the state, and it was never a serious challenge. I will mention three other NGOs that date to this same period, which similarly deserve praise, but also raise questions about their grassroots 'authenticity', their impact, and their ultimate sustainability: The Association of Nuns and Laywomen of Cambodia, Buddhism for Development, and Santi Sena.

Let me preface my observations by describing a visit, together with a group of young researchers, to a training centre near Oudong of the Association for Nuns and Laywomen of Cambodia. The young American researchers were universally impressed by the nuns and the centre: the quiet dignity of the NGO staff, the organization's basic assumptions about the importance of women in the Buddhist context, and its dedication to fulfilling an active social role. We learned of its training sessions and its programme for helping orphans. I was perhaps the only one present who was feeling a grain of doubt, as I calculated in my mind the numbers of people actually touched by this organization and compared it to the hundreds of 
nuns who would have been resident, just down the road, at a meditation centre associated with the monk Sam Bunthoeun. Which place was finally more deeply rooted in the Cambodian experience and which place finally had greater social impact? Which place was more sustainable?

The ANLWC was founded in 1995 following a conference on 'The Role of Khmer Donchees and Lay Women in the Reconciliation of Cambodia', sponsored in part by the Heinrich Böll Foundation (HBF), which has been a major funder of the organization. (The HBF country representative for Cambodia for several years was Hema Goonatilake, a Sri Lankan scholar and activist who was also deeply interested in nuns' movements in Sri Lanka.) The first director of ANLWC, Sobunvy Kong, was a returnee from refugee camps on the Thai border who had travelled throughout Cambodia to find nuns and laywomen interested in participating in the project. While ANLWC also has the sponsorship of Queen Norodom Moninieach Sihanouk (now the Queen Mother) and individual donors who sponsor some of its smaller projects, it has relied heavily on the funding by the HBF. Like the Dhammayietra, it has a clear transnational element; it is linked to international networks of women's Buddhist associations. Like those transnational movements, its public literature is framed in the terminology of social activism: human rights, women's rights, empowerment, combating domestic violence. Meditation is taught to promote 'mental health'.

At least one scholar (Guthrie 2004) has questioned whether such an organization takes the institution of female asceticism too far away from its original social roles (which, in contrast to ANLWC literature, she claims was not restricted to serving monks slavishly). Most Western observers have felt an attraction to the organization and its goals, and one would be hard pressed to criticize an organization that asserts women's dignity, cultivates transnational networks for women, and pursues a humane social agenda. But questions remain as to how deeply such an organization is or can be rooted in Cambodian society. Meeting with its field director in May 2006 I was told that its HBF funding was expiring and that this might mean the end of the organization. While I remain optimistic that it will find other sources of international funding, it remains true that, up to the present time, most Cambodians who make donations would make them to wats or to individual monks or nuns, and not to an NGO.

Two other NGOs, Buddhism for Development and Santi Sena, seem more firmly established in the NGO world, but raise similar questions. Both were founded by monks and originally heavily focused on the participation 
of monks, but seem to have moved in the direction of lay social activism. Santi Sena was founded in 1995 by Ven. Nhem Kim Teng, a monk who had close links to the Dhammayietra. Nhem Kim Teng was born in Svay Rieng province in Eastern Cambodia and as a young man went as a monk to an ethnic Khmer wat in Saigon, where he found himself when Cambodia fell to Pol Pot. He stayed in Vietnam through the Khmer Rouge period, left the monkhood for a year, and was eventually re-ordained at a wat in the Mekong Delta. He returned to his home province in the 1980s and was able to remain a monk despite the restrictions on young monks at that time. In the mid-1980s he made contact with Maha Ghosananda because at that time visitors to Cambodia flew to Ho Chi Minh City and travelled by land to Phnom Penh, and Maha Ghosanda stayed in his wat, near the Vietnamese border, several times. He was invited to attend trainings in the border camps in preparation for the first Dhammayietra march, and became a key figure in the early years of the organization. He founded his NGO in 1995 believing that the goal of a socially engaged Buddhism needed to be pursued on a number of fronts. Buddhism for Development was founded in the refugee camp Site II in 1990 and even claims to be the first NGO in Cambodia. It may have originally represented a different, more anti-communist strand of Buddhism in camp than that associated with the Dhammayietra, but it came out of a similar logic, perhaps very natural in the context of a refugee camp, that religion combines naturally with social service.

By now, the philosophies of the two NGOs are quite similar. They seem quite firmly established at the present time, BFD in several provinces in Western Cambodia and Santi Sena in three eastern provinces. Heng Mony Chenda received a scholarship to pursue a Master's Degree at Harvard in the 1990s, during which time he left the monkhood, but he continues to be the driving force of the NGO. He has written several books, published and distributed by the Konrad Adenauer Foundation (a key early funder of the NGO since it was established in the refugee camp, although it receives funds from a range of international organizations now); the books are widely known and respected in Cambodia. Nhem Kim Teng is currently pursuing a doctorate in New Delhi, where he is writing a dissertation on Buddhism and social activism in Cambodia.

Opening BFD's website, one sees a slogan associated closely with the Dhammayietra, 'Put Down the Gun! Take up the Dharma!' followed by a statement of its 'vision': 
'An educated, democratic society free from poverty and preventable illnesses, law abiding and respectful of human rights and the environment. A moral society with respect for Buddhism and Cambodian culture and traditions whilst being aware of the threats and opportunities of globalism.'

Santi Sena uses similar language:

\section{Vision}

Santi Sena is keen to see the Cambodia people live in peace, justice, social well-being and dignity and in harmony with Cambodia's rich eco-system and natural environment.

This is in accordance with the Buddhist precept Sate Sappa Aharati Thika which means that every human being needs to survive and therefore must have to [sic] access to basic needs (food, life security, shelter and society).

\section{Mission}

To alleviate poverty through improving close co-operation with relevant governmental institutions: to encourage and support local initiatives; to focus the work on vulnerable and marginalized people; to reduce social violence; to promote human rights, democracy, social legislation and advocacy; to empower women; and to contribute to the conservation of natural resources.

This means carrying out the monks' main roles: learning Buddhist scriptures, advising people on how to survive in the right way, conserving the bio-diversity/biosphere, building a peaceful society, providing security for human beings who are in need and conserving patrimony and traditional values. But first the monks themselves have to clear themselves of hatred, greed and delusion.

\section{Goal}

To ensure that all people, especially small farmers, women, disabled men, youths, elderly people and children are living in better and more satisfactory situations.

(Nhem, no date).

While the two organizations have different emphases, they have similar roots, are engaged with similar types of projects, use similar language, and probably receive funding from similar international organizations. Both 
seem to be very solidly established NGOs with a high success record with grass-roots social development projects and trainings in social issues.

On a recent visit to Santi Sena's headquarters in Svay Rieng, a staff member explained that the NGO always included both monks and laypersons on its staff. He explained the increasing numbers of lay staff in the central offices by saying that now there was an increasing need to hire staff by means of resumés and job interviews. This is perhaps another way of saying that international networks of funding inevitably push in the direction of international standards of professionalism, and that this almost inevitably steers the NGO away from an emphasis on using monks.

On the same visit, Nhem Kim Teng argued that there was increasing interest in social activism in the Cambodian monkhood, and he was surely right that as monks become increasingly educated, and as they have more and more contact with the movements among monks in other countries, this philosophy of Buddhism will be more and more difficult to ignore. Perhaps the publications of Heng Mony Chenda and Ven. Nhem Kim Teng will play an important role in this process. On the other hand, he conceded that the movement was not spreading in the form of NGOs. The impetus in the early to mid 90s which created ANLWC, BFD and Santi Sena does not seem to have continued, at least not in that exact form.

One should stress that while one can speak of these organizations in terms of their common ideological roots, they also demonstrate the way that an ideological framework confronted and shaped institutional possibilities at a certain historical moment. To take just one concept as an example of how an idea develops institutionally, we can look at the currency of the idea, much discussed in this period, that Buddhism and human rights are in some underlying way 'the same' - often stated that human rights and the 'five precepts' are the same. This is an idea whose development in Cambodia one can trace. While more generally, the concept of human rights began to be promoted in Cambodia by Sihanouk in the early independence era, the idea of links between Buddhism and the philosophy of human rights is a more recent phenomenon. The promotion of this idea in Cambodia is closely associated with the work of Ven. Yos Hut, a Mahanikay monk who went to France for study in 1973, and who worked with the United Nations Border Relief Organization (UNBRO) in refugee camps in the 1980s; he maintained a centre for Dhamma discussion in Site II, separate from the large wat whose abbot was Ven. Pin Sem. (Like Nhem Kim Teng he would be involved with the Dhammayietra movement.) He early on decided 
that human rights training in the camps should be done from a Buddhist perspective.

Once UNTAC was set up in 1992, Dennis MacNamara, the former head of UNBRO, became the director of the UNTAC Human Rights Division. In that capacity he invited Yos Hut to be a cultural adviser. An early report by Yos Hut for the UN emphasized the consistency of human rights with Buddhism. One cannot in a simple fashion say that the UN made a calculated decision to use Cambodian Buddhism for promoting human rights, but a complex pattern was set up whereby expatriate Cambodian intellectuals such as Ven. Yos Hut or human rights activist Kassie Neou would promote the idea, which was then given institutional weight by the $\mathrm{UN}$ at an important moment.

In this process, an NGO called the Khmer Buddhist Society seems to have played a key role. KBS was originally the charter organization of a Cambodian Buddhist Temple in Seattle, Washington. It received funding during the early UNTAC period to do social service training in Cambodia. One of the founders of the training project, Ou Bun Long, was in particular interested in projects that were Buddhist in orientation, even though its early funding, by the US through the NGO PACT, was not open to that possibility. He learned in 1993 that there was UN money for training in human rights, and wanted the project to involve Buddhist monks.

$\mathrm{Ou}$ Bun Long says that the Khmer Buddhist Society received money from the UN before any other human rights organizations - initially US\$120,000. They started in 1994 with courses for the mekon, the ranking monks at the provincial level, and their deputies, 48 monks in all, with classes eventually held at Wat Unnalom, the wat of the Mahanikay patriarch, who became the honorary head of the project. Over the course of the project, its two sources of funding have been the United Nations Center for Human Rights in Cambodia and the Interchurch Organization for Development Cooperation.

The original teachers were Ven. Yos Hut, human rights activist Kassie Neou, and a Cambodian woman from the UN Human Rights Center. Neou had already been teaching human rights in the public schools, and was a strong advocate of using the framework of monastic schools to teach human rights. However, they decided to focus on teaching monks at wats instead of schools. They developed curriculums which expanded in scope over the course of the project, drawing on the expertise of UN consultants. They had their students, the monks, write sermons using the ideas. The teacher 
would then read and correct the sermons as they were written. The idea was to get monks to teach the abbots of other temples as well as their lay communities. Some abbots were better preachers than others. Since some abbots traditionally read sermons instead of speaking spontaneously, they provided these monks with texts they could read as sermons. Over time, classes were set up in provincial capitals, with monks coming from the subdistrict level to take classes.

In 1997 the organization broke its ties with the Khmer Buddhist Society in Seattle and became a local NGO, at the same time breaking with the PACT-funded social service training project. The same year the project began training a group of 27 monks to be trainers in the project. These trainers were sometimes assistants to provincial mekon; the project tried to choose well-educated monks who were good speakers and well liked within the monastic community. Each trainer was to teach 400 monks in the course of a year, in classes of 50 . (Trainers received a stipend of US\$1 per monk trained, as well as travel expenses.)

Perhaps one should be careful not to give too much credit to KBS in this process. All the previous-mentioned Buddhist NGOs have also given training in human rights and emphasized the links to Buddhist concepts, using similar language. Kassie Neou's Cambodian Institute for Human Rights also made heavy use of this idea. But probably it was KBS's systematic programme of training monks to train monks which had the biggest impact on the monkhood itself. In conversations with monks in Phnom Penh and rural areas, I have found that the idea 'stuck' in some way, at least to the extent that monks, if asked about human rights, will readily come out with a rather formulaic response that human rights is really the same as the five precepts. What saying this actually means to these monks is another question. But these monks at least have some familiarity with the term 'human rights' and at least a superficial 'naturalization' of this concept in the field of Buddhist discourse has occurred.

Hughes criticizes the effect of this, arguing that human rights as a concept is thereby deprived of some of its basic meaning and force.

It is significant that these interviewees, and others who spoke similarly about human rights, did not talk about a similarity of underlying aims between human rights and Buddhism, but spoke as if the 'five commandments' of Buddhism were identical to human rights provisions in law. For these interviewees, arguably, the details of international human rights norms are 
of secondary importance to the objective of creating a new basis for order in society...

Arguably, human rights and Buddhism become fused since, in the eyes of most respondents, the anarchy responsible for human rights abuse in Cambodia can be overcome by the propagation of an authoritative moral code. Human rights, as promoted by the international community, offer one such code. Within Cambodia, the principles of Buddhism, already widespread among the population despite the disruption of the 1970s and 1980s, offers another. Conflating the two creates a discourse which connects the grassroots to the international community, facilitating exercise of international power and protection at the grassroots level.

(1998: 300-301)

In propagating concepts drawn from international law, as well as from Buddhism and from notions of morality, the approach of the human rights NGOs movement is didactic, rather than participatory.

Discipline, professionalism, and adherence to imposed norms of behavior are emphasized, at the expense of deeper forms of democracy or individual freedom facilitated through empowered community forums of discussion and action. A harmonious relationship between a centralized and hierarchical government apparatus, and Cambodian citizens, sharing a mutual respect and rightful conduct, is viewed as the appropriate goal. Frequently this goal is framed in terms of visions of an idealized past.

(Hughes 1998: 306)

One could equally argue that Buddhist concepts are diluted, distorted and jargonized by contact with the discourse of human rights. Many Buddhist concepts are very clumsily presented in the early literature in Cambodia. While thinkers like Heng Mony Chenda and Nhem Kim Teng show greater sophistication, drawing in part on the way that these ideas have been used in emerging discourses of neighbouring countries, such questions of, for example, the degree to which the five precepts can be said to represent a similar orientation to the world as the International Charter of Human Rights, are by no means straightforward.

Perhaps the main point to be made here is that what is taking place here is a complex discursive process. Both sides, the Buddhists and the UNtrained human rights activists, could be said to be using the other, and the results may or may not ultimately be regarded as 'authentic'. But they tell us something about religion as it is functioning in the Cambodian context. 


\section{DISSIDENT MONKS}

If the period since the UN mission has been characterized by increasing 'civil society', then the issue of the degree to which public protest may be coloured by religious issues is a relevant one. The debate surrounding this has been largely focused on the degree of monks' participation in political activities - and in particular public protests.

Like Thailand (and unlike Sri Lanka) Cambodia traditionally did not allow monks to vote, and the idea that monks should remove themselves from the political sphere has significant currency. However, as in all Theravada countries, there is a significant history of monks playing political roles at key junctures. One would like to attribute this to the idea that the idealistic pursuit of spiritual ends leads naturally to the idealistic pursuit of social ends. But one might argue more simply that the involvement of monks in political protest is in great part simply a function of the fact that they are of an age where it is natural to work through political philosophies and test them out in practice, and the fact that they are in regular discussion with other young men in the intense social community of a wat makes it natural that debate will occur. This is doubly true in urban wats where male university students traditionally share quarters with monks. One should never forget how ordinary the young men are who enter the monkhood; on the other hand, young monks enjoy in their own way a kind of power and prestige, and their presence at any public event changes its complexion.

When the UN organized elections in 1993 it declared that monks and prisoners would be allowed to vote, a decision doubtless based on electoral philosophies current within the UN with little reference to its implications in the cultural terms of a specific location. Since then there has been debate about whether monks, even though they have the vote, actually should vote. Some prominent monastic leaders even in 1993 discouraged monks from voting. This has continued to be debated, with the issue especially hot at the time of the 2003 elections, when monastic authorities declared that monks should not vote, whereas opposition parties insisted on the legal right to do so and encouraged them to defy the injunction. Some commune chiefs supported the injunction and refused to allow monks to vote (despite their constitutional rights) and some wats threatened to expel monks if they voted (Falby 2003). (Oddly, in 2006 the Mahanikay patriarch Samdech Tep Vong reversed his earlier position and said that monks could vote.) 
In 1993 I visited urban monks in their dormitories who had political materials posted on their walls and clearly favoured certain parties. One would also often see monks at political rallies, although it was not so clear whether their presence represented an endorsement so much as an acknowledgement of the appropriateness of having monks as a ceremonial presence at any public event.

The period of demonstrations following the 1998 elections is particularly relevant here, since monks conspicuously took part, and when the demonstrations were violently suppressed, police did not hesitate to use violence against monks. Two reportedly were killed. In the aftermath of this, police sought out monks who had been involved in demonstrations at their residences in various urban wats and beat them or otherwise intimidated them. Many such monks were forced to leave the monkhood.

While I may be wrong, I do not believe that the participation of monks in demonstrations reflects any larger pattern of political organization among monks, and I do not see that any monks have emerged as leaders as a result of this process. What we have, I believe, is the informal enthusiasm of individual monks, who link themselves on an ad hoc basis to movements as they assume public prominence. This may change, but monastic authorities are doing everything they can to prevent this.

In February 2006, following the release of several political prisoners, monks were a conspicuous presence in a March for Freedom of Expression and Non-Violence in Cambodia, which took place at the time of a Buddhist holiday, Meak Bochea, and involved a march between two important cosmological centres of Cambodian Buddhism, Wat Phnom in Phnom Penh and the site of the new Sakyamunichedi in Oudong. The march echoes the Dhammayietra marches and more clearly took place in the name of abstract ideals than the 1998 demonstrations. Nevertheless, led by activist Kem Sokha, it had a clear political agenda. Once again, one wonders what kind of organization is operative here, and whether the link to the monkhood will prove sustainable.

\section{SAM BUNTHOEUN AND BUTH SAVONG: MOVEMENTS SURROUNDING RADIO PREACHERS}

Ven. Sam Bunthoeun and Buth Savong represent two spiritual leaders who came to prominence in the 1990s and achieved considerable fame among the general population, perhaps in both cases because of the popularity of 
their radio sermons and their vision for new organization within existing Buddhist structures. Although there are significant differences, I see them as representing a similar pattern for a number of reasons. Both were born about the same time and represent a generation of Cambodians who lived through the Pol Pot period as youths and derived significantly their religious vocation from the Pol Pot experience. Neither of them were in refugee camps, and each in different ways faced the problem of pursuing a religious vocation in the 80 s when young monks were not officially allowed. Both seem to have been extremely charismatic figures, although neither pursued the tradition of giving blessings with water associated with other charismatic monks. Their most significant appeal has been to the mass of the population as much as to powerful individuals who go to them as an occult source of blessing. They have both emphasized that their teachings derive from the study of Buddhist scriptures, and to that extent are in what some have called the 'reformed' tradition, but both are also identified strongly as having deeply Khmer roots. Both have organized their followings around the social organization of the wat, instead of NGOs - but both in some sense challenge and redefine the nature of the Cambodian wat. Both have large followings of female ascetics. From what I have been able to determine, they both (despite Sam Buntheoun's eventual assassination) rested fairly comfortably within the current political order and received major donations from important political figures. Nevertheless, I will argue that in both cases their popularity derives in part from their implicit embodiment, consciously or not, of a critique of the order.

\section{Ven. Sam Bunthoeun}

Ven. Sam Bunthoeun was born in 1957 in Muk Kampul district of Kandal province - that is to say, a rural district but close enough to Phnom Penh to in some sense be in its ambit. A booklet published on the occasion of his death (Ganna kammathikä buddhamandal vipassanā thura 2004) describes the great efforts he went through to obtain an education prior to the Pol Pot period, finally completing three years of high school in Phnom Penh before the city fell to the Khmer Rouge in 1975 and he was evacuated with the rest of the population to the countryside. After 1979, he was reunited with his family in his home district, and, feeling called to be a monk, was ordained as a novice in 1980. Although his ordination as a bikkhu would be in Kampong Cham province, he was primarily based in Muk Kampul for the next fifteen years, during which he vigorously pursued the study of 
the Buddhist scriptures, including the Pali language. He became known as a preacher and a teacher and, unusually for a Cambodian monk, practised vegetarianism. He initially resisted the study of vipassana meditation, but, encouraged to try it in the mid 1980s, found it had a powerful healing effect on him. As his skill in it improved he began teaching it himself.

It is difficult to sort out exactly how Sam Bunthoeun's school of meditation emerged in conjunction with a number of other schools and centres that appeared in the early and mid 1990s. Maha Ghosananda's movement was always closely associated with the practice of meditation, and the Dhammayietra marches were construed as a form of walking meditation. (Ven. Yos Hut, one of the monks identified with Maha Ghosananda leads meditation sessions at Wat Lanka popular with nonCambodians.) The then Minister of Culture, Cheng Phon, created a Center for Vipassanā and Culture on the outskirts of Ta Khmaw, in Kandal province, which was originally, in the late 1980s, a place for artists to study meditation in relation to performance, but acquired more general fame by the UNTAC period, when it became known as a place for foreigners and more sophisticated Cambodians to do vipassana studies. Pou Tonghav, a Cambodian-American with a pre-Pol Pot background in politics, had studied vipassana with S. I. Goenka in the US and India in the early 1980s, was ordained as a Theravada monk, and returned to Cambodia following the Paris Peace Agreements. He began teaching the Goenka system in 1992, first in Phnom Penh and then, after 1994 in a district of Kandal province close to the Vietnamese border. A vipassana centre was also created at Wat Samrong Andet in 1994, with teaching by ethnic Khmer monks from the Mekong Delta of Vietnam. One should keep in mind that Cambodia had a pre-war tradition of vipassana meditation, primarily by older monks and doun chi or laywomen, sometimes associated with sites on or near holy mountains. This was however a very much localized practice, and without much prestige or organization. It seems to be the tradition that Sam Bunthoeun came from, although it may have been the arrival in the early 1990s of more internationally oriented teachers that pointed to the possibility of meditation practices he knew being taught on a greater scale and in a more systematic fashion in Cambodia.

According to the booklet about Sam Bunthoeun's life, the annual council of monks decided in the mid 1990s to declare formally the validity and importance of vipassana meditation, and thereupon called Sam Buntheoun to go to Phnom Penh to teach it. He told them that, rather than be affiliated 
with one of the more established wats, he would rather be in a quiet wat on the outskirts of the city; consequently he settled at Wat Nuntamony and set up his meditation school there in 1995. Earlier that year, while he was still at Muk Kampul, land was acquired near Phnom Attaraq in Oudong with the intention of setting up a major meditation centre there. This was before the decision had been made to construct a huge stupa (a sakyamunichedi) at the top of the hill to house the Buddha relic which at that time was in front of the Phnom Penh train station, but the eventual construction of the stupa would put Sam Bunthoeun's centre at what was being construed as one of the more cosmologically central locations in the country. At the time he moved to Phnom Penh he also began giving sermons regularly on the radio, which were very popular.

By 2000 the centre at Oudong was sufficiently developed for him to begin living there. (He also that year enrolled as a student in the Pali university in Phnom Penh, despite his monastic seniority to many of his classmates.) He had by this time begun publishing books on meditation and completed several before he died. The centre at Oudong attracted hundreds of students, the majority of them older women, but large numbers of older men and monks as well. The central building of the centre is a oversized sala in which meditation could be taught to large numbers of people en masse. Significantly, teachers who had been trained in Oudong then set up smaller centres in thirteen provinces. My own sense of the scale of the movement first took hold when I visited one of these regional centres at Wat Cheoung Prey in Batheay district, Kampong Cham, a row of meditation huts for doun chi and older monks set up in conjunction with a small shrine on the edges of the wat. An institutional structure was being created which could reproduce itself, and one that was readily embraced by Buddhists at grassroots levels.

The assassination of Sam Buntheoun on 8 February 2003 has never been adequately explained. He had reportedly received agitated telephone calls earlier in the day and then was shot twice in the chest by gunmen as he left Wat Lanka, a large busy temple in the heart of Phnom Penh. No one has ever been prosecuted for the crime. Of many stories in circulation about the reasons for the assassination, none is really satisfying. Perhaps the most likely version is one often told by monks who had had some contact with him. According to this version, a major contributor to his projects was the wife of a prominent businessman, who had turned to him when her husband's business was in crisis. After following Sam Bunthoeun's 
advice and taking up meditation, the business miraculously recovered. She consequently plunged more and more deeply into religious practice; however, her husband became jealous of her increasing devotion to and what seemed to him a romantic obsession with Sam Buntheoun. Tensions escalated to the point that he had Sam Bunthoeun killed.

Another story holds that the killing was a reprisal for Sam Bunthoeun's decision to change contractors at the Oudong centre. More political explanations are also in circulation; soon after the assassination, an opposition party tried to claim the death as martyrdom to their cause. (I have found no believable evidence that he was sympathetic to the political opposition.) Even more fantastic are stories that the hit was arranged by the Mahanikay patriarch because of Sam Bunthoeun's support of monks having the right to vote, or that the death had to do with Sam Buntheoun's opposition within the monkhood to the practice of ritual blessings with water (sraouch touek). The main thing to be said about these stories is that no totally convincing explanation has really been found, and the public continues to grope to understand it in terms of the few facts known and popular conceptions of the political realities. Since the assassination Sam Buntheoun's body has lain in state in a refrigerated glass case at the centre in Oudong and is a popular attraction for visitors.

Although it is difficult really to know, indications are that the projects Sam Buntoeun was affiliated with are still flourishing. Construction at the centre in Oudong continues apace and as of mid 2006 the imposing outer structure of a huge preah vihear had been completed. According to a 2005 article in a popular magazine, there were 300 doun chi and 100 monks present at the centre. It is now administered by a committee of 15 persons. I found that meditation classes at Wat Nuntamony and Wat Cheoung Prey (the latter during the rainy season retreat period every year) had not lost any of their momentum. Although broadcasts of radio sermons by Sam Bonthoeun are much less frequent than those of Buth Savong, tapes are still played on one radio station, said to be paid for by one of the more charismatic politicians of the dominant party.

It is difficult at this point to evaluate the degree to which, while still alive, Sam Bunthoeun embodied a critique of Cambodian religion and social order. Perhaps any leader calling for purer religious practice is a reformer in some way. Individuals sought out his centres as part of personal processes of quest - reflecting social weariness which can be found in any society but might be especially prominent among those who have lived through the 
upheavals of Cambodian society. Sam Bunthoeun came to be a well known name among grass-roots Buddhists. Insofar as the people studying with him came from all parts of Cambodia and maintained something of a network system after they left, they represented an alternative to the bureaucratic structure of temple Buddhism. Although the hierarchy of monks over nuns was not challenged, the centres associated with Sam Bunthoeun definitely had a respected place for women. His centre happened to be at a place which authorities were working to build up as cosmologically significant, and his proximity, combined with his rising fame, put him in a position to compete for some of the glory of that space. While it is absurd to think that his death had anything to do with his refusal to perform sraoch toeuk, his stance does put him in contrast with other monks who became close to the political leadership of the country.

But it is the mystery surrounding his death which finally, in the popular mind, means that he has come to be associated with a critique of the social order. The ambiguities surrounding his death leave open a range of possibilities, including the possibility that he challenged the social order whether he actually did or not. Of course, the mere fact that the authorities have not sought out and punished those who committed the crime makes the continuing presence of his body an implicit, symbolic critique.

\section{Buth Savong}

Buth Savong was born in Sangker district immediately outside of Battambang provincial town in 1960. He attended primary school there and was in secondary school in the provincial town when he was evacuated into the countryside after the fall of the country to the Khmer Rouge (Buth 2005). His mother died during the Pol Pot period. Like Sam Buntheoun, he was ordained as a monk in the period immediately after the fall of the Khmer Rouge. However, while he managed to remain a monk in his home village for four years, he eventually, unlike Sam Buntheoun, yielded to government restrictions against young monks and was disrobed in 1984. Nevertheless, in doing so, he vowed to continue living virtually as a monk. Somewhat like the figure of Anagarika Dharmapala in Sri Lanka (Gombrich 1988: 188197), he has devoted his life to Dhamma study, dresses in white, shaves his head, and, it is said, follows monastic disciplinary restrictions more carefully than most monks. A biographical sketch in an English-language version of one of his books says he began teaching Dhamma in Battambang in 1980 (when he was a monk) and Abhidhamma in Phnom Penh in 1997. 
In Phnom Penh he now lives in a simple Chinese-shop-house-style home in the vicinity of Tuol Tompong market, sharing the residence with his assistant, a former Russian-language teacher from Battambang who has adopted a similar ascetic lifestyle, and what seems to be a variable number of elderly doun chi.

He emerged as a well known Dhamma teacher on radio in the mid 1990s. He gives talks four days a week, two at Wat Unnalom and two at Wat Samphiw Meas, except during the rainy season, which he spends in retreat in Battambang. According to his followers he has by now some two thousand tapes of sermons which are distributed free or can be purchased. He has also written several books of inspirational preachings and poetry.

Although some Cambodians I have spoken to criticize Buth Savong for not actually being a monk, his peculiar role puts him in the position to criticize the monkhood at a time when many are dissatisfied with it and feel it lacks qualities which they remember it having before the Pol Pot period. $\mathrm{He}$ is thus both in some sense a monk and in some sense outside and above the monkhood. He has been closely associated with the call for disciplinary reform within the monkhood. Wats which come to be associated with him adopt much tighter disciplinary control than what is normally found in Cambodia. Since the wats affiliated with him are Mahanikay, it is striking that some of the reforms he insists on, such as monks not handling money and going barefoot, are already common in the Thammayut disciplinary practice. But he does not advocate turning to the Thammayut but to his own conception of disciplinary purity.

Perhaps the wat which is now the clearest showcase for his movement is Wat Kol Totoeung, situated near the Bassac River in Kheang Svay district of Kandal province, an easy drive from Phnom Penh. It has only recently, under Buth Savong's supervision, been established as a wat, and when I first visited it, in around 2000, it was still registered only as an 'asram' with the Ministry of Religion. Like other wats I have visited which are associated with Buth Savong, it is immaculately clean and exudes a sense of peaceful orderliness. Monks' sleeping quarters have small windows on the doors allowing supervisory monks to check on their activities at all hours of the day. The wat was busy with instruction in Pali, Abidhamma and meditation, and there was the use of computers for instruction. Wats associated with Buth Savong have certain distinguishing characteristics: a central Boddhi tree, a small house designated for Buth Savong to stay when he is resident 
(sometimes never used), and a statue of Buth Savong in the monks' eating hall.

One interesting thing is the emphasis on a practice whereby, in order to avoid favouritism toward any of the resident monks, lay visitors wishing to make donations to individual monks choose numbers in a sort of raffle, so that they are paired at random with one of the monks in the temple. This practice has a scriptural basis, and in Cambodia was traditionally used on particularly large ceremonial occasions, but seems to be given special emphasis by Buth Savong, to the extent that it is the basic organizational principle of some ceremonial gatherings. There are now some 30 wats around the country which identify with Buth Savong and his teaching, and they have their own internal network, participating in each other's ceremonial occasions. His name is well known among Buddhists in rural areas, and significant numbers of young monks seek out his wats because they hope to find there a purer, more authentic Buddhist experience.

As the history of Buddhism in Southeast Asia well shows us, reform movements have the potential for creating divisions which are sometimes fought about fiercely. One of the first wats associated with Buth Savong, in Battambang, ended up with a major break between his followers and those who resisted the reforms - to the point that one group left and founded a new wat. One cannot help wonder whether, if Buth Savong's influence continues to grow, this might occur elsewhere. But there have been no recent schisms of this sort, and they may have partially been avoided by the fact that so many of the wats affiliated with him are new creations, and by the fact that the wats now have their own network with one another. He has followers in countries with large Khmer populations and has made several trips to Australia, Europe and the US, as well as to Buddhist sites in India and Sri Lanka. A fairly sophisticated web-site is devoted to him (www. dhamma4khmers.org), apparently constructed by a group of followers in California. This organization is also working to translate his books in English.

As with other religious leaders, an important part of his appeal, but one very hard to write about, is the 'aura' he exudes in his person. While any such evaluation is totally subjective, I will venture to say that he is the Cambodian Buddhist leader who, at least to me, most intensely conveys a feeling of spirituality - although such evaluations inevitably raise questions of what that aura really consists of and how it has been generated. Many observers conclude that Buth Savong must have intense personal experience 
of meditation, although in his actual teachings he has not emphasized this, and it is possible that his aura derives from other kinds of ascetic practices.

The topic of Buth Savong seems inevitably to include discussion of his political affiliation and although, as far as I know, he never specifically makes political references, Cambodians often say that he is comfortably in the fold of the ruling party. It is a high-ranking CPP official who succeeds in raising sufficient funds so that his sermons can be broadcast on all the different radio stations in the country. While it is beyond the scope of this article to analyze his teachings and writing in any detail, at least one regular listener to his sermons has argued to me that the fact that Buth Savong tends to preach a philosophy of accepting one's lot in life serves well the wishes of the authorities. But despite the frequency of such comments, I believe that his appeal lies in what is actually a very complex relationship to authority. He does, finally, represent someone who was forced to leave the monkhood, and his principal role has perhaps been one of righteous critique of the monkhood which once excluded him. While his goals may not be particularly inconsistent with those of the state authorities, he is definitely an unsettling personage who thrives in an atmosphere of grievance and hunger for greater purity and order.

At least one incident demonstrates a level of discomfort with him on the part of the religious authorities. At Wat Kol Totoeung a striking stupa has been built to house what is described as a Buddha relic. (The relic had been brought from Sri Lanka to the United States, but after no adequate home was found for it there, someone close to Buth Savong suggested he build a stupa for it in Cambodia.) Wat Totoeung, near the national agricultural school, also has a relic - and a pattern perhaps was emerging whereby wats affiliated with him would tend to house relics. While the cult of relics is not as important in Cambodia as it is in Sri Lanka, Buth Savong's stupa at Kol Totoueng was built around the same time as the sakyamunichedi at Oudong and perhaps reflected some of the excitement surrounding that project. In some minor way it was competing as a cosmological centre. Then when word reached the religious authorities that Buth Savong planned to bring yet another relic to Cambodia and establish it in another wat affiliated with him, Wat Prey Risey, on the distant outskirts of Phnom Penh near the border with Kampong Speu province, they acted to block this. The decision was made by a council of high-ranking monks and seemed to represent their stance that the Buddha relic at Oudong should have clear dominance 
in the country. All this is to say that Buth Savong is a force to be reckoned with, but that if he ever proves over-reaching, there may be forces which are prepared to counter him.

\section{CONCLUSIONS}

The movements I have discussed here have grown at a time of rebuilding Cambodian Buddhism, where the very idea of 'building' has become something of a fixation. Rebuilding has taken place in a new context of donor networks. What is salient is that sources of funding have opened up which did not exist before UNTAC. (This is especially relevant for understanding the NGO movements.) At the same time a new political-economic logic has meant that some businessmen and politicians have acquired great wealth and have been able to make conspicuously large religious donations of a size that could never have been in Cambodia before. (The situation may have some parallels to the situation of taxation referred to in Chapter 1 of this book, where the rice-based self-sufficiency economy, as it existed prior to 1975, has been replaced by one dependent on flows from above.) Religious leaders like Sam Buntheoun and Buth Savong received donations from overseas Khmer, but perhaps owe their prominence ultimately to newly powerful people in the country.

The movements discussed here raise the question of the degree to which religion can challenge the social order. To the degree that it does, it was doing so in new ways in the period following 1989. Certainly a school of thought emerged in Cambodia for the first time since the 1960s, associated closely with Buddhists with connections to refugee camps, that Buddhism can and should be concerned with social action. The leaders of these movements tended to form NGOs in the UNTAC period, and several have survived to the present day. While one should not overlook the productive work being done by these NGOs, I do not ultimately see the NGO structure as 'connecting' with grass-roots Cambodia, and I do not see significant new NGOs being formed along these lines. This may be to say that the religiously affiliated NGO still has the feel of having been 'inserted' into Cambodian society, much as Öjendal and Lilja talk about democracy having been 'inserted' - and one wonders to what degree they will need to transform if they are really to survive. Hybrid ideologies, such as those attempting to meld human rights with Buddhism, are one result of this; I do not want totally to dismiss them, but the results are sometimes incongruous. NGOs 
that originally were dominated by monks or nuns have taken on more and more of a lay orientation in order to survive as NGOs, which may show a basic discomfort with combining religion with the structure of NGOs at this time, although the fact that this kind of combination has had greater success in Thailand is an indication that there is no inherent obstacle to it. The hope for these movements may ultimately be in the publications of its key players. New socially oriented religious ideologies may yet catch fire in Cambodia, but there is nothing inevitable about their progress, and how exactly they will work themselves out in practice remains to be seen. There are clear patterns of dissidence among Cambodian monks in this period, but one similarly does not yet see any sustainable organization arising with this purpose.

The cases of Sam Bunthoeun and Buth Savong are interesting, because they are examples of movements that have genuinely captured the imagination of grass-roots Cambodians. Such movements have worked within the social institutions of Cambodian Buddhism while subtly (or not so subtly) critiquing it. They show that Buddhist movements can challenge the social order, and to the degree that everything in Cambodia seems to become politicized it is natural that they will - but perhaps only to the extent that they conform to it on a superficial level. Religion perhaps always has this ambiguity, of at one level legitimizing social institutions while at the same time providing a discourse which questions it.

\section{REFERENCES}

Buth, Savong (2005) Parents' Words of Wisdom. Phnom Penh: Dhamma4khmers.org

Falby, Patrick (2003) ‘To Vote or Not to Vote: Buddhism's Monks Debate Their Rights.' The Phnom Penh Post, 19 June.

Ganna kammathikā buddhamandal vipassanā thura [Committee for the Vipassana Meditation Center] (2004) Jivapravatti brah thammavipassanā Sam Bunthyn Ketuthammo [Biography of the Vipassana Tacher Sam Bunthoeurn Ketuthammo]

Gombrich, Richard (1988) Theravada Buddhism: A Social History from Ancient Benares to Modern Colombo. London: Routledge.

Guthrie, Elizabeth (2004) 'Khmer Buddhism, Female Asceticism, and Salvation'. In John Marston and Elizabeth Guthrie (eds), History, Buddhism and New Religious Movements in Cambodia. Honolulu: University of Hawai'i Press, pp. 133-149.

Harris, Ian (2001) 'Buddhist Sangha Groupings in Cambodia.' Buddhist Studies Review 18(1): 73-106. 
- - (2005) Cambodian Buddhism: History and Practice. Honolulu: University of Hawai'i Press.

Marston, John and Elizabeth Guthrie (eds) (2004) History, Buddhism and New Religious Movements in Cambodia. Honolulu: University of Hawai'i Press.

Poethig, Kathryn (2004) 'Locating the Transnational in Cambodia's Dhammayatra'. In John Marston and Elizabeth Guthrie (eds), History, Buddhism and New Religious Movements, Honolulu: University of Hawai'i Press, pp. 197-212. 


\section{Re-establishing Legitimacy through the Extraordinary Chambers in the Courts of Cambodia}

\section{Laura McGrew}

Legitimacy has long been sought by the Royal Government of Cambodia (RGC): bringing leaders of Democratic Kampuchea (DK) or the Khmer Rouge to internationally recognized trials is one strategy towards legitimacy that the RGC is pursuing. The path has been long and tortuous, fraught with many logistical and political landmines, but the 'mixed' Extraordinary Chambers in the Courts of Cambodia (ECCC) finally began official operations in February 2006. ${ }^{1}$ Foremost among the blockages may be the make-up of the RGC, dominated by the Cambodian People's Party and including former Khmer Rouge cadre: thus the RGC has never been able to discuss this issue with one voice, nor any voice that is totally without a past. A second major difficulty is the Cambodian judiciary, which is said to suffer from corruption, lack of capacity and resources, and which is politically influenced. The ECCC is taking place within this flawed Cambodian court system. The purpose of this chapter is to analyze the various motivations of the RGC as it seeks legitimacy (both internal and external), yet at the same time seeks to control any damage or fallout from the ECCC. The influences of other major forces such as the political parties, civil society and the international community will also be discussed. Finally an analysis of the key issues will be presented in the context of Cambodian society and culture, related to transitional justice and reconciliation, the legacy of the ECCC, and the controversy of closing the chapter of Cambodia's dark past in order to look to the future. 


\section{THE HISTORY AND STRUCTURE OF THE ECCC}

This section reviews recent political history in the lead-up to the trials, briefly summarizing the long convoluted road taken by the many stakeholders with multiple interests and competing world views. Following this is a brief summary of the structure of the ECCC.

In the reconstruction or reconstitution of Cambodia, the competition between the two paradigmatic shifts of multi-lateral intervention and a universal demand for democratization created an interesting nexus around the search for justice and accountability for the crimes that had occurred during the Khmer Rouge regime. The international intervention of the United Nations Transitional Authority in Cambodia (UNTAC) imposed a political solution on the reluctant Cambodian parties. At the same time, the democratic process and the elections, which came very early in the process (too early many argue), resulted in the unwieldy political solution of a coalition government, which has yet to produce a consolidated democracy. The trade-offs required to meld the two processes of intervention and democratization, as well as the resulting inherent political instability and the pressures from various international players, have been exhibited in the lengthy and difficult negotiations around the ECCC. Compromises have been made on all sides, but the solution is a complex creature which is proving difficult to implement (see further below).

Although the various Cambodian governments have made substantial progress since 1979, including the restoration of some basic infrastructure and services (e.g. roads, schools, health care, education, religion), postconflict Cambodia is still fraught with problems. One of the most serious problems now is the rampant corruption which permeates particularly government, but also reaches all levels of society and interferes with real sustainable development. There is a lack of trust in government and the degree of internal regime legitimacy is questionable. Impunity is a way of life, with almost no accountability for public officials. This impunity is linked to the ECCC: many argue that as long as any Khmer Rouge leaders are still living freely, and justice has not been meted out, the impunity problem cannot be solved. Some argue that the ECCC could actually be a solution towards decreasing impunity, and if run well could make great inroads in solving some of the other problems of the judiciary, as well as increasing trust and popular legitimacy. 


\section{THE POLITICS OF THE ECCC}

Throughout the 1980s, the Vietnamese and Soviet-backed People's Republic of Kampuchea's (PRK) raison d'être was to destroy the Khmer Rouge. In the immediate aftermath of the fall of the Khmer Rouge regime, the PRK scurried to hold a trial of two particular Khmer Rouge leaders: Ieng Sary and Pol Pot. This 'show trial' was widely condemned by Western observers and indeed international standards were sorely lacking. The accuseds' own defence lawyers, including Dith Munthy, stated, 'As defenders, we have not found any ground to deny the criminal acts mentioned in the bill of indictment' (Group of Cambodian Jurists 1988). ${ }^{2}$ Although Cambodian officials argue that their government has already tried these Khmer Rouge leaders, because of the lack of international standards this trial has brought little legitimacy - internal or external.

As the Paris Peace Agreements were crafted in the late 1980s, pressures changed, and the US, China, Thailand and other major powers pushed the Cambodian government (the PRK changed its name in 1989 to the State of Cambodia or SOC) into a marriage of convenience with the discredited Khmer Rouge. In the 1991 Paris Peace Agreements, an obtuse phrase allowed all the parties, including the international community, to sweep the deaths of 1.7 million Cambodians under the carpet: there was to be no return to the 'policies and practices of the recent past' (United Nations 1991). There was no mention of genocide or crimes against humanity. The political compromises made in order to bring the Khmer Rouge leaders into the agreement themselves caused a 'silence' about the previous mass violence. Then when the Khmer Rouge withdrew from the peace agreements, war was renewed and they were once again viewed as criminals. 'In Cambodia, the peace process left behind contradiction, not reconciliation in the political arena' (Doyle 2000: 102).

UNTAC, as well as the post-UNTAC Office of the Special Representative of the Secretary General and the Office of the High Commission for Human Rights, did take some small steps towards the preparations for the ECCC. During the UNTAC period, assistance was provided to the judiciary, the UNTAC criminal law was created, human rights training was provided - and the environment created by UNTAC nurtured the mushrooming of NGOs, including many human rights NGOs. This international presence allowed some opening and movement towards the independence of the judiciary, and some minimal acceptance of NGOs in monitoring. However, 
the ruling party resisted real change in spite of ten years of attempts at legal reform. Although the government has said that it is committed to the establishment of the rule of law, its efforts are weak as the flow of power, resources and loyalty passing through patron-client networks would be threatened (Un 2004: 162).

In addition, the situation left after UNTAC, with an unstable and unwieldy coalition government (between CPP and FUNCINPEC) and a former partner to the negotiations (the Khmer Rouge) left outside to fight, made the search for accountability even more problematic. Both CPP and FUNCINPEC were racing to bring the Khmer Rouge into the fold (and were even encouraged to do so by the international community for the sake of peace and stability). A 1994 law to outlaw the Democratic Kampuchea Group was designed to provide an amnesty for those former Khmer Rouge who joined the government. The guerrilla war that had been taking place ever since the Khmer Rouge withdrew from the peace process was a continual drain on the government's energies and coffers. People living in the North and Northwest of the country were frequently displaced and there were casualties from combat as well as land mines. This situation of hurting stalemate was felt by all three major Cambodian political parties. By 1998, once most of the Khmer Rouge senior leaders had been rendered powerless, Cambodians were encouraged by their Prime Minister to 'dig a hole and bury the past'. After all this shuffling between punishment and forgiveness, many Cambodians are frustrated and have lost trust in the government to deliver a truly fair and neutral solution. The lofty goal of the ECCC to achieve both justice and reconciliation is extremely difficult. Given the vagaries of the shifting sands of the international community, as well as those of various Cambodian factions who remain with many grievances, an entirely satisfactory solution for all parties is hard to reach.

Several books and articles have discussed at length the details of the attempts to bring the Khmer Rouge to justice (Hammarberg 2001; Fawthrop and Jarvis 2004; Etcheson 2004; Boyle 2005; Maguire 2005). There are many different views on the range of culpability of the various parties in causing the delays to the process, including the RGC and various members of the international community, in particular China but also Vietnam, France and the United States. Most authors and observers acknowledge there are some flaws in the mixed tribunal solution - and some think the flaws will be fatal. Fawthrop and Jarvis are sympathetic to the RGC, primarily blaming certain members of the international community and the UN for delays 
and for political complacencies, allowing DK to maintain Cambodia's seat at the UN throughout the 1980s. They also argue that the RGC made many efforts to try the Khmer Rouge, including holding the world's first genocide trial in 1979. They feel that the current solution of a hybrid tribunal in Cambodian courts is innovative, and the best solution for Cambodia.

On the other hand, Amnesty International (1998, 1999, 2002, 2003a, 2003b) and Human Rights Watch (1998, 2001, 2002a, 2002b, 2003a, 2003b) have issued multiple press statements criticizing the UN, the international community and the RGC, and state that the mixed tribunal solution does not meet international standards. Historian Steve Heder argues that the UN had little power to maintain international standards when Japan, France, the US and Australia were pushing them to compromise (Heder 2002: 217). Another criticism Heder makes is that the politically expedient solution restricts jurisdiction to a few top leaders only, and ignores the possible culpability of lower level cadre to go unexamined (Heder forthcoming). Boyle, Hammarberg, Etcheson and Maguire dissect the negotiations and legal issues in detail, and apportion blame to all sides of the negotiating table (Hammarberg 2001; Etcheson 2004; Boyle 2005; Maguire 2005).

During the negotiations, a game was played both by the UN and the RGC, as during the pauses each side would say they had done their part (and thus been legitimized), and were now waiting for action on the other side. Meanwhile outsiders, including the Cambodian people, became very tired of this game and increasingly more cynical. The lack of involvement of the Cambodian public in the creation of the ECCC was another problem. Although civil society has tried to be involved at various points in the negotiations, this ECCC solution was essentially that of the very top leaders of the RGC and the UN. More specifically, Prime Minister Hun Sen and the now Deputy Prime Minister Sok An and the Office of Legal Affairs of the United Nations worked out the details of the deal; but the outcome also included some compromise solutions made by various other actors. ${ }^{3}$ Many Cambodians have felt disenfranchised and distant from the process, and lack trust in the government (McGrew 2000:13; Linton 2004: 20; Urs 2007: $70,75-76,89)$.

In June 1997, the then Co-Prime Ministers sent a letter asking the UN to assist with a tribunal for the Khmer Rouge. ${ }^{4}$ Although this step officially started the process which has resulted in the mixed tribunal solution of today, there was initially a long hiatus in negotiations due to the violent events of July 1997. The struggle between the two parties and Co-Prime 
Ministers for power had reached a particularly high peak in 1996 and 1997 as Hun Sen and Ranariddh competed to bring the Khmer Rouge (leaders, soldiers and riches) into their respective parties - both for their own versions of 'national reconciliation' (Ashley 1998). 'The Khmer Rouge offered disciplined cadres, effective guerrilla soldiers, and up to US $\$ 200$ million secreted in Southeast Asian bank accounts' (Doyle 2000: 92). In fact this competition over the Khmer Rouge (and the CPP's inability to accept a militarily strong FUNCINPEC) was one of the main factors causing the violent coup d'état by CPP against FUNCINPEC in 1997. After a show trial of Ranariddh in which he was found guilty of 'illegally negotiating with the $\mathrm{KR}$, and illegal arms dealing' the King immediately pardoned him and politics continued as usual in Cambodia - though Ranariddh was in a severely comprised opposition and there was a further consolidation of power by the CPP. Former DK Foreign Minister Ieng Sary won out in these deals: he was given an amnesty in August of 1996 for his conviction in the 1979 trial, while other senior leaders Nuon Chea, Khieu Samphan and especially Ta Mok were left to face the calls for accountability. 'The amnesty for Ieng Sary and other Khmer Rouge defectors was extremely successful [for the RGC] on a political level: of the 6,624 Khmer Rouge soldiers who joined the Cambodian government, almost 3,000 received positions in the Cambodian army (among them three brigadier generals, nine colonels, and thirty lieutenant colonels)' (Maguire 2005: 102).

The governments of the United Kingdom, France and Australia have played particular roles in the prosecution of former Khmer Rouge leaders, as they have sought justice for the three young men who were kidnapped by the Khmer Rouge from a train in Kampot in 1994 and subsequently killed. Both Hun Sen and Ranariddh were seeking validation (and certainly also monetary rewards) from these foreign governments as they were both involved in negotiations to free the men. Trials have been held for some of the accused Khmer Rouge kidnappers, and these governments have been amongst those pushing for the ECCC.

The other remaining senior leaders or other notorious authorities such as former Tuol Sleng Prison Chief, Kang Khek Iev (Duch), were conveniently rendered impotent either by defection, arrest or death. In April 1998, Pol Pot died (already incapacitated by a stroke, he allegedly died of natural causes, though poisoning is suspected), but not before he had stood before a people's trial in the Khmer Rouge-controlled area organized by Ta Mok and was found guilty and sentenced to life in detention. Ta Mok was arrested in 
March 1999, while Nuon Chea and Khieu Samphan defected in early 1999 in a public ceremony at Hun Sen's home. Khieu Samphan said publicly 'let bygones be bygones', which was not well received by many Cambodians. Duch, after being discovered by photographer Nic Dunlop, started talking openly and apologizing, until he was arrested in April 1999. For many years, only Ta Mok and Duch were in custody accused of crimes committed by the Khmer Rouge, both held in the Military prison in Phnom Penh. In July 2006, Ta Mok died from apparently natural causes while still in military custody. Finally, the ECCC began issuing detention orders, and in July 2007 Duch was transferred to the ECCC detention centre; the issue of his lengthy detention period (way beyond international standards) has been raised before the court. Nuon Chea was arrested in September 2007, and Ieng Sary and Ieng Thirith in November 2007. The negotiations over the ECCC were a very long and slow process which often put political expediency above international law. Both the RGC and the international community's record on the ECCC have been mixed, as various countries have had major influences on Cambodia's internal affairs. These many mixed motives and interests have resulted in the ECCC structure that exists today.

\section{THE STRUCTURE OF THE ECCC}

In 1999 the RGC created a 'Task Force on the Extraordinary Chambers' headed by Deputy Prime Minister Sok An, and a Secretariat which for several years carried out the planning for the ECCC. ${ }^{5}$ On 4 February 2006, UN Deputy Administrator Michelle Lee arrived in Cambodia, and the joint work of the UN and the RGC began under the 'Extraordinary Chambers in the Courts of Cambodia' (ECCC). The purposes of the ECCC as stated by the Task Force in an informational booklet also used by the ECCC are: to hold the senior leaders and those most responsible accountable for their crimes; to set the historical record straight; to provide justice to the Cambodian people (those who died and the survivors); to educate the younger generation about the KR period; to strengthen the rule of law; and to contribute to the reconstruction of society (2004: 5).

The law to create the Extraordinary Chambers in the Courts of Cambodia to Prosecute the Crimes Committed during the period of Democratic Kampuchea from 17 April 1975 to 7 January 1979 was passed by the National Assembly, then signed by the King on 10 August 2001. On 6 June 2003 the United Nations and the RGC signed the agreement 
to establish the ECCC. This agreement was finally passed by the National Assembly on 4 October 2004, along with the revised ECCC law. The budget of US $\$ 56.3$ million includes 43 million to be provided by the international community and 13.3 million from the RGC (although the government has sought assistance for all but 1.5 million of that amount). ${ }^{6}$ In March of 2006, the former staff of the Secretariat of the Task Force joined with the UN staff to form the institution of the ECCC based at a site $40 \mathrm{~km}$ outside of Phnom Penh. The international and Cambodian judges and prosecutors were sworn in on 3 July 2006, and staff levels at the court have slowly been increasing. After a long contentious period of discussion between the Cambodian and international judges, the Internal Rules of the ECCC were finally adopted on 12 June 2007 so the court could finally begin its full functions.

Although the basic structure of the ECCC is delineated in the laws, the agreement and the internal rules, many issues are not clear, and there is concern that the lack of clarity could result in delays - if not miscarriage of justice. As is well acknowledged in this volume and elsewhere, the Cambodian judiciary is fraught with problems and is often cited as being corrupt, incompetent and not independent (ADHOC et al. 1999; Amnesty International 2000 and 2003; USAID 2004; Un 2004; United Nations Economic and Social Council 2004; World Bank 2004). These reports note that the judiciary, the Ministry of Justice, the Ministry of Interior, indeed the entire government is controlled by the ruling party, the Cambodian People's Party (CPP). By holding this ECCC within the existing court system, the risks of a non-independent process are high as noted often by the ECCC's strongest critics - Amnesty International and Human Rights Watch (see section above). On the other hand, other organizations such as the Documentation Center of Cambodia and the Open Society Justice Initiative argue that in the negotiations over the ECCC, the UN has included many safeguards to try to prevent interference in the process, and they are more supportive of the ECCC. Several members of Cambodian civil society, notably the Cambodian Human Rights Action Committee, made important efforts to encourage greater independence and the meeting of international standards for the ECCC. ${ }^{7}$

This unique, mixed or hybrid tribunal (a mixture of Cambodian and international law and personnel) has two chambers: a trial chamber, or first instance court, consisting of three Cambodian and two international judges, and an appeals chamber of four Cambodian and three international judges. ${ }^{8}$ Decisions are to be made by unanimity, or if not possible by 
supermajority $^{9}$ (majority plus one). One each international and Cambodian serve as co-prosecutors (Mrs. Chea Leang and Canadian Mr. Robert Petit) and co-investigating magistrates (Mr. You Bun Leng and Mr. Marcel Le Monde from France). If there are any disagreements between them, a 'pre-trial chamber' (three Cambodian and two international judges) can rule as to whether or not a prosecution will proceed - as well as on other issues noted in the internal rules. There are many references in the laws and agreements to international standards, and judges and prosecutors are supposed to be independent, impartial and have integrity and experience. Judges may rely upon international procedures in the case of gaps and/or uncertainties. The Cambodian director of administration along with his international deputy director is responsible for the various sub-units of the ECCC, which include the sections: public affairs, court management, personnel, general services, information and communication technology, budget and finance, and security and safety. Defence lawyers can be provided for the accused through the Defence Support Section if they show financial need, and the section provides other support and training for defence. The Victims Unit and witness protection and support services are provided. For budgetary and planning purposes (as well as for the stated purpose of national reconciliation as noted above) the UN and RGC agreed upon an estimate of between five and ten senior leaders to be indicted. ${ }^{10}$ As this unique structure was developed several years ago, other courts have used the formula as a reference, including courts in Sierra Leone and East Timor. Many of the ECCC's creators had hoped that it could serve as a model for other justice processes; indeed the RGC had hoped its external legitimacy could be enhanced.

Although civil parties (victims) attached to criminal proceedings are allowed under Cambodian law, under the Khmer Rouge law and agreement this issue was not clear and did not seem likely to happen. However in the internal rules, there are many explicit references to civil parties, and the ECCC Victims Unit, which was only created in late 2007, is struggling to develop forms, procedures and data-base formats to receive the complaints. Civil parties to the proceedings will be grouped together depending upon their claims, and will have access to the court through legal representatives. Although the procedures and structures are still not ready, the Unit is working the best it can with limited resources and in close coordination with the NGOs. There remains a lack of funds for legal representation and many other problems, but there is good will to surmount these, and if done 
well, victims' voices could be much better heard at the ECCC, which would vastly increase its legitimacy.

A security commission in the Ministry of Interior which also includes military police was established primarily to oversee security matters, although there has been some confusion about the role of the police in investigations. The ECCC is housed in a compound built for the military's high command: two of three existing buildings are used for the ECCC while one remains for the senior military officials, and a detention facility was built in the compound and officially opened in July 2007. So although the Cambodian police are in charge of ECCC security, since the military compound is adjoining the ECCC compound, the military will also be involved in security issues. The RGC has high stakes riding on maintaining security for tribunal staff, witnesses, defendants, as well as the general security of the public - if achieved, another source of legitimacy. But Cambodians in general distrust the police and the military, because among other reasons they have been implicated in many human rights abuses (LICADHO 2003; Human Rights Watch 2004). In their bid for enhanced legitimacy, the RGC will simultaneously have to maintain security and deal with the legacy of the mistrust of and past misconduct of the police. Security, the legacy of past human rights abuses and public participation in the ECCC are inextricably linked, and the RGC and the ECCC will have to deal adequately with all of these issues in order to achieve a successful and legitimate ECCC.

The RGC, in its quest for legitimacy through the ECCC, faces many risks but also can benefit from opportunities. To minimize the risks, there is great need for public outreach, to ensure that Cambodians understand the process, have realistic expectations and are able to access the trials. In order for Cambodians to support these trials, and the RGC role in them, they need both physical access during the trials, as well as a broad-reaching outreach programme into the countryside to inform the public about the ECCC as well as to obtain their views. If outreach to the public is inadequate and expectations are unrealistic, the ECCC will not be a success and could actually damage the legitimacy of both the RGC and the UN. Unfortunately, the budget for outreach and victim and witness support remains very small, and totally inadequate to undertake these important tasks. Since the ECCC is almost entirely externally funded, it will be up to the donor community to consider more funds, but the RGC should also appreciate the importance of this work and find other ways to support it. 
One major threat to legitimacy has already occurred, with information from an independent audit, which noted serious problems with recruiting and hiring, training and other administrative issues, being leaked to the press. ${ }^{11}$ Further allegations of kickbacks to Cambodian senior court officials and other senior government officials, which are common knowledge to longterm Cambodia-watchers, but are difficult to prove, have severely damaged the ECCC's reputation. ${ }^{12}$ The ECCC has responded by publishing the audit, and the ECCC Director of Administration (Sean Visoth) has instituted some of the recommended changes in administrative procedures, and he has made several public pledges to crack down on corruption. However, it remains to be seen how the RGC and the ECCC will be able to institute real change, and if there is the political will to do so.

\section{THE MOTIVES AND INTERESTS OF THE KEY ACTORS}

Several key players have particular motives and interests that have affected the process of coming to the negotiated solution for the ECCC. The RGC and other political parties have their own pasts, presents and future hopes to deal with, as do sub-factions within each. The Royal family, in particular former King Sihanouk and Prince Ranariddh, have been closely involved. The Cambodian people (reflected by civil society) have arguably the strongest interest in a successful ECCC, though they have had little input. External actors, particularly certain members of the international community (China, Japan, France, the United States and Australia), have played important roles. The ECCC solution reflects all of these factors.

\section{The Royal Government of Cambodia (RGC)}

Although many individuals in the RGC no doubt wish to find justice for themselves and Cambodians at large, the RGC's quest for legitimacy is primarily based on external pressures to hold this tribunal - dredging up the past is just too risky for many members of the ruling elite. If however the tribunal were to take place, be internally and internationally recognized, and at the same time not cause any embarrassment to the political leadership, internal legitimacy would also be achieved. Thus, the RGC's motivation is to control the process as tightly as possible to prevent embarrassment or the implication of some individuals in prosecutions, or any threats to power.

The RGC today wants presumably to be seen as a legitimate government internationally. This is evident through, for instance, the bidding for one of the non-permanent seats on the UN Security Council and the ambition to 
becoming a major player in ASEAN. The RGC is very proud of its status as the first developing country to join the WTO, and is proud of signing the Rome Statute. Thus the RGC is also motivated to hold an internationally acceptable ECCC: another bridge to cross to achieve its goal of obtaining legitimate status internationally.

Both internal and external legitimacy are factors affecting the RGC's motivations towards the ECCC. The internal legitimacy aspect was very strong during the early 1980 s. A priority of the post- 1979 government and their Vietnamese backers was to remind Cambodians of their hatred for Pol Pot and the need to fight the Khmer Rouge-led forces at the border. This was done by immediately restoring the Tuol Sleng Prison Museum and Choeung Ek killing fields site, by putting in each province a memorial where piles of skulls served to remind people of the killing fields, and by instituting a large public anti-Khmer Rouge ceremony every 20 May, the 'Day of Hate'. Although this political memorialization was de-emphasized once the Khmer Rouge were included in the Paris Peace Talks, Prime Minister Hun Sen could still benefit internally if he were the leader who was able to defeat the Khmer Rouge, and bring justice to the people so that the 'chapter can be closed'.

The RGC states that its policy in its ongoing efforts to achieve justice for the crimes of the Khmer Rouge has been guided by three fundamental principles: respect and search for justice; maintaining peace, political stability and national unity; and respect for national sovereignty (Sok An 2002: 6). In addition the goal of the RGC is presumably to generate legitimacy but at the same time avoid de-legitimization - the RGC does not want to be seen as a failure in being able to carry out these trials. Sovereignty and national pride are important issues. There have been many public statements from government officials saying this is a Cambodian matter that needs Cambodian attention - thus also the argument for having these trials in domestic courts. But a CPP insider noted:

The government has contradictory desires - the KRT [i.e. ECCC] is seen as an opportunity, as many other international forums, to be recognized worldwide on issues the world cares about. [The government leaders] don't want their names tarnished by the dark history. But they also don't want the international community to control the process, or the content of process. So they make lots of efforts to control the process - the players delay when it is not comfortable. 


\section{The Political Parties}

The various political parties have different interests and motivations, and have used the ECCC as a tool to criticize each other. All of the parties have been involved with the Khmer Rouge in the past and are seeking to avoid being tarnished, while at the same time to enhance their own power and legitimacy. The most influential of the various political parties is the CPP, which controls virtually all aspects of government. Internal CPP history and politics are very difficult to decipher and highly secretive. There are many opinions as to whether the RGC and individual members of it really want this ECCC. Several current CPP leaders have played major roles in the Khmer Rouge. Before 1975, a few current CPP functionaries had either been part of the Khmer Rouge and returned from France, while others had been in the jungles but fled to Vietnam in 1977 or 1978 (Heder forthcoming: 9). Although in the popular press and rumour Prime Minister Hun Sen is often accused of being a senior leader of the Khmer Rouge, historian Steve Heder suggests 'no hard evidence linking him directly to crimes has come to light' (Heder forthcoming: 10). However due to the various ties between the Khmer Rouge regime and some current government officials, there are many different individual and group concerns that would arise in trials for Khmer Rouge leaders. The CPP continues, as have all previous Cambodian governments, to consider both domestic and external forces in determining foreign policy - in consideration of maintaining power and achieving legitimacy (Peou 1997). ${ }^{13}$

The prospect of tribunals is complicated by the fact that in the 1980s there was disagreement between former DK Eastern Zone cadre and those who had been in Hanoi over the issue of the importance of 'blood debts', and vestiges of both of these groups still exist in the CPP. Some of these former DK cadre were described as 'having blood debts, who have killed with their own hands or issued direct orders to kill... or who made lists of cadres, Party members and the masses and reported them to the higher level to be killed' (Gottesman 2003: 67). For those former cadres with a history within the Khmer Rouge, talk of the ECCC could be worrying.

The other parties have had a more distanced relation to the ECCC. The inconsistent and fluctuating Prince Ranariddh was a key player in both the Paris Peace Talks and at the Thai-Cambodian border with the CGDK, and he would have had direct relationships with former Khmer Rouge leaders - including business deals related to gems and logging. He played a key role in originally asking for the ECCC from the UN in a letter both he and Prime 
Minister Hun Sen signed, but in the last few years has not been involved at all: thus perhaps he has maintained his distance from the ECCC. 'Our priority is poverty reduction' (Pin 2005). Prince Ranariddh has recently been totally disenfranchised in his formerly major role as party leader of FUNCINPEC, which has split into two. He is now leading the Norodom Ranariddh Party, but both royalist parties have almost completely disintegrated and it is not likely that they will gain any seats in the 2008 elections.

Opposition leader Sam Rainsy has also played a changing role in the process of the Khmer Rouge coming to trial. Several times he has called for an international tribunal, and has often stated or implied that Prime Minister Hun Sen or other key members of the RGC should be prosecuted. For example, he said 'I think the time has come to set up a genocide tribunal like in Rwanda to stop the killing hands of CPP, of Hun Sen' (Maguire 2005: 132). But he has also been aligned with former Khmer Rouge personnel. In 1994 he was a strong backer of laws outlawing the Khmer Rouge - but with the goal of encouraging defections, as during this time he was also competing with Hun Sen and Ranariddh to recruit former Khmer Rouge personnel to his power base. In several elections, Sam Rainsy campaigned heavily in former Khmer Rouge areas with remarkable success in Pailin and Kampot. Although his popularity has recently been declining, his support for or criticism of the ECCC can play a role in its success in Cambodia.

\section{The King(s)}

The now retired King Sihanouk played a pivotal role in the creation and support of the Khmer Rouge but his role has also been very inconsistent. When he was overthrown by the US-backed Lon Nol in 1970, Sihanouk joined the Khmer Rouge as titular head and many Cambodians were persuaded to follow him. However when the Khmer Rouge took power in 1975 he was installed in Phnom Penh but was then kept under house arrest; 19 family members were killed during the Khmer Rouge period. Sihanouk then supported the anti-PRK Coalition Government of Democratic Kampuchea (CGDK) throughout the 1980s. Over the years 'King Father' Sihanouk has changed his position on the ECCC many times, but lately he has been quite negative. His son Sihamoni followed Sihanouk to the throne in 2004. King Sihamoni was with his parents from 1975 to 1979 under house arrest in Phnom Penh. He and other family members presumably have views on the Khmer Rouge period, including about the rule of Khieu Samphan (who was one of the family 'minders'), and could be called to 
the ECCC as witnesses. As King, Sihamoni heads the Supreme Council of the Magistracy, which appointed the judges to the ECCC, so in theory he could wield a great deal of power. However he has remained studiously out of politics, instead concentrating on sending aid to the poor, visiting the provinces and carrying out his many ceremonial duties. Kings Sihanouk and Sihamoni, as well as other members of the royal family, could influence the legitimacy of the ECCC, both externally and internally. Since the monarchy remains an institution revered by a portion of Cambodian society, especially in the countryside, public statements could affect the participation of Cambodians in the ECCC as well as its perceived legitimacy. For example, there was a public dispute fought via the press between King Sihanouk and Prime Minister Hun Sen over the bones on display at Choueng Ek: Sihanouk called for them to be cremated while Hun Sen wanted to keep them for evidence. ${ }^{14}$ In another recent brouhaha Sihanouk called ECCC officials to the palace to receive his statement, but they did not respond, so he staged an elaborate breakfast meeting with empty chairs on television. ${ }^{15}$ He presumably wanted to show the public that he was ready to talk, but that the ECCC wouldn't listen. These theatrics only serve to prove to his nonsupporters that he has something to hide. To his (mostly older) supporters the nuances make little difference in sustaining his semi-god-like position in their eyes.

\section{Civil Society}

The Weberian definition of legitimacy in this volume's Chapter 1 is based on the assumption of a reciprocal relation between people and state ... but without popular support, it can only rule through sheer power'. This describes Cambodia today, as the RGC holds and wields sheer power. Up until 2004, the dialogue on the ECCC was essentially between two parties, the RGC leadership (predominately CPP) and the UN. Although civil society has tried at various times to influence the process and share their opinions, attempts have been largely unsuccessful. Only once the ECCC law was passed did civil society start to have more influence and input into the process, though this has still been minimal. As the process unfolds, the RGC may be forced to loosen its hold on the process and allow civil society (as stipulated in the ECCC law) more access and input. This may already be happening to some degree as evidenced by the allegations of corruption and mismanagement that the RGC finally had to respond to. If the dialogue and interaction increases, the RGC can actually build increasing internal legitimacy, which 
can lead to increasing external legitimacy. The international community and the international members of the ECCC staff would play a crucial role in this process. Indeed Brinkerhoff argues (2005: 5) that 'reconstituting legitimacy in the post-conflict states involves expanding participation and inclusiveness ... creating accountability ... [and] re-establishment of the rule of law'. The ECCC presents as an opportunity for the RGC to improve dialogue with civil society and in the long run increase legitimacy.

Civil society has played a negligible role in the negotiations over the ECCC. In spite of several attempts at surveys ${ }^{16}$ (McGrew 2000; Linton 2004) and public statements by Amnesty International, Human Rights Watch and the Cambodian Human Rights Action Committee, ${ }^{17}$ the negotiations for the ECCC were done in secrecy with only occasional efforts by the UN to consult civil society leaders and with no public discourse at all initiated by the government. In fact, it has been the opposite. Civil society calls for international standards or attempts to be heard on certain issues such as a transparent and fair process for judicial appointments were largely ignored. Civil society remains profoundly distrustful of the government's intentions concerning these trials, and worried that the ECCC will not be able to function in the dysfunctional court system. To combat this distrust, increasing civil society's role in the process - and in wider legal reform - could dramatically increase the legitimacy of the ECCC.

Too often, rule of law assistance neglects the need to build consensus among national stakeholders on the type of reform needed. As a result, rule of law reforms ... can lack the necessary legitimacy to be truly effective in providing the platform for sustainable peace and development ...

Malloch Brown 2004: 2

Although the previous surveys are incomplete and not representative, the various public opinion polls have come up with findings that are quite similar: most Cambodians polled want a tribunal, but would prefer an international tribunal. They want to know 'the truth': why Khmer killed Khmer, and who was behind the Khmer Rouge. Thus the mixed tribunal solution is already flawed (and not fully legitimate) in the eyes of many Cambodians - though most agree that at least this partial international presence is better than nothing. How to deal with many other issues such as security, remembrance, forgiveness and apology are also very important, and also under-researched. 
Throughout the process leading towards the ECCC, civil society has also played an important but limited role in documentation, outreach, advocacy, monitoring and reconciliation - in particular the Documentation Center of Cambodia (DC-Cam). ${ }^{18}$ Once the ECCC is under way, civil society (including the media) will have an increasingly important role to play in the wider issues of reconciliation and healing in the recovery of society from the mass violence of the Khmer Rouge period. In order for the process to be validated, however, civil society must be consulted. Although it remains impossible to predict to what extent reconstruction and reconciliation will be achieved by the ECCC, hopes are high in some quarters. Various members of civil society have spoken about their goals for this trial: (1) bring justice to the millions of victims; (2) clarify the historical record; (3) heal the trauma; (4) enhance rule of law to end/decrease impunity; (5) improve the legal system (Sok 2005). These wide-ranging goals are seen as unobtainable by some, especially the international human rights NGOs (as noted previously). In addition, the surveys include a minority view that some Cambodians are tired, too much time has passed, and they no longer want a trial and would prefer the money be spent on poverty reduction (McGrew 2000; Linton 2005). But these civil society goals are essentially outlining how the government could achieve internal legitimacy through these trials and such sentiments are repeated again and again: 'If we do wrong, maybe now, nobody cannot kill us or put us in jail, or cannot blame us or sanction us, but later there are the others who can make sanctions for others who do something wrong. This could make the people, happy, make them confident, make them trust law' (Interview with NGO staff 2005).

\section{External Actors}

The international community, through both action and inaction, has played a key role in the catastrophe of the Khmer Rouge in Cambodia, as well as the aftermath - many members also have particular interests and motives and fear being sullied by the ECCC process. From the 1960s when the then Prince Sihanouk tried to balance the Cold War superpower struggle over communism in Vietnam, through the Khmer Rouge period, the US, the former Soviet Union, Vietnam, France and China all played important roles in Cambodia. In spite of evidence of gross human rights violations, the UN supported the discredited DK to hold the Cambodian seat at the UN from their fall in 1979 until 1992, as the Paris Peace Agreement was being implemented through UNTAC. By the late 1990s, the international 
community was ready to wash its hands of the Cambodia problem and exhibited a relatively strong and coherent approach resulting in UNTAC and a silence on Khmer Rouge atrocities. However, this coherent approach was waning by the time of the 1997 grenade attack and 'coup'. 'Cambodia was no longer the critical crossroads of the Cold War and it threatened neither regional stability nor great power relations. Secondly, donor fatigue set in' (Brown and Timberman 1998: 113). Thus the ECCC negotiations, which started in mid 1997, and the final product of the mixed ECCC solution, were fated to be victims of multiple external actors and multiple and changing interests.

The scope of the ECCC is to include only the 'senior leaders and those most responsible' and only events that occurred between 17 April 1975 and 7 January 1979. Even though various foreign governments were involved before, during and after this period, it is politically impossible to include any of them as defendants in trials in Cambodia - though Cambodians constantly ask about this at public forums. However, various actors (including defence lawyers and some witnesses) will want to highlight the following roles of foreign governments in Cambodia: Vietnam for support to and the creation of the early days of the Khmer Rouge; the US for bombing Cambodia in 1973; China for its support of the Khmer Rouge during the regime; and China, the US, Thailand and others for support of the Khmer Rouge and their partners Coalition Government of Democratic Kampuchea (CGDK) after 1979. There is much suspicion amongst Cambodians as to the role China and Vietnam played in creating and supporting the Khmer Rouge. Many blame China, partly because of its visibility during the Khmer Rouge years, and Vietnam is blamed in its role as historical enemy. On the other hand, the CPP often brings up the role of the US in the 1960s and 1970s; at various times during the negotiations, Prime Minister Hun Sen called for US government officials to testify at the ECCC.

China was the government that played the largest role in the creation and support of the Khmer Rouge, and hundreds of advisers were present during the Khmer Rouge period. There has been much speculation about the role of China in blocking negotiations for the ECCC. ${ }^{19}$ '... Albright and the Americans received a significant setback on June 25 [1997], when China, the Khmer Rouge's greatest patron, announced that it would not support the creation of a UN war crimes tribunal for Cambodia. This move should have been anticipated, given China's historical relationship with the Khmer Rouge. Cui Tiankai, the spokesman for the Chinese foreign ministry, 
framed the issue in terms of national sovereignty and maintained that 'it should be decided by Cambodians themselves without foreign interference' (Maguire 2005: 134). Former Special Representative of the UN Secretary General for Human Rights in Cambodia, Thomas Hammarberg, stated in reference to the ECCC in 1999: 'The Chinese were actively working against any further UN initiative' (2001: 15). Vietnam, in spite of embracing its role as liberator of Cambodia from the Khmer Rouge in 1979, must also certainly be concerned about what could come to light during the ECCC concerning their role in the early years of the Indochinese communist party and the creation of the Khmer Rouge. These alliances are almost certainly factors delaying the ECCC.

Japan has agreed to pay for more than half of the ECCC, and has played a pivotal role in pushing it to go forward. It provides significant foreign aid to Cambodia, and has been gradually increasing its role in Asia, in competition with China. If Japan assists Cambodia to 'close the chapter' of the Khmer Rouge then more attention can be paid to economic development in the region. Cambodia also supported Japan's bid for a permanent seat on the UN Security Council. The RGC can gain legitimacy in the eyes of Japan and enter fully the Southeast Asian economic community only once the ECCC has been (successfully) completed.

The United States has also played a pivotal role in the both the Paris Peace negotiations and the negotiations for the ECCC, and although especially since the July coup they have given little aid directly to the Cambodian government, they provide a great deal of assistance through NGOs. They have been closely involved with the creation of the ECCC, and in 1994 the US Congress passed the 'Cambodia Genocide Justice Act', which created a programme at Yale University - the local office of which became DC-Cam. For many years the US Congress prohibited the US government from giving money to the ECCC, ${ }^{20}$ although other support for monitoring and other legal assistance is allowed. In spite of this complicated history between Cambodia and the US, the RGC seeks legitimacy from the US in the world arena, especially with the RGC bid for a seat at the UN Security Council. The recent discovery of oil off the coast of southern Cambodia has softened the US stance towards Cambodia, and relations between the two countries have been slightly warming. The US has also sought Cambodia's cooperation on the International Criminal Court and on fighting terrorism.

The United Kingdom, France and Australia have all pushed for a tribunal, related to seeking justice for the deaths of their nationals by the 
Khmer Rouge in 1994. France also has a special interest in Cambodia, as Cambodia was a former French Protectorate, with the legal system based on the French civil law system. France has also supported the judiciary and police for many years, as has Australia and Japan. These three countries have all been major donors to the ECCC. Germany has also been supportive and this support has increased in 2006 and 2008. The German development foundation (DED) is giving substantial funds to several NGOs involved in outreach, victims support as well as some projects working towards the larger goal of reconciliation. The European Community has also provided a large grant to Adhoc to do outreach (unfortunately these areas remain woefully underfunded).

As a large percentage of Cambodia's budget still comes from foreign aid, the RGC must carefully balance the donors. If the RGC and its donors can maintain a stable, peaceful Cambodia, they hope that economic development can proceed. While many of the international organizations and Western donors are pushing for the legal reforms linked to their economic packages, with Cambodia's entrenched webs of corruption based on patronage the more flexible aid packages from certain Asian countries, in particular China, are undoubtedly more attractive to the RGC than the more restrictive oversight of Western and international institution donors. ${ }^{21}$ An important aspect of Cambodia's full acceptance into the world community is related to economic factors. Burke-White argues that one justification for prosecutions is the desire 'that Cambodia re-enter the international community, as a full participant in international economic and political affairs' (Burke-White 2005: 15). He suggests that prosecutions could lead to increased status in the international business community and thus increase economic growth, including tourism.

The various roles of the international community have certainly not always been forthright nor grounded in international law - it has not been an easy job for the RGC (or any Cambodian government) to balance the conflicting pressures. Several of the international actors are tired after giving so much aid to Cambodia in the past, and want to 'close the chapter' of the Khmer Rouge and 'move forward'. The ECCC solution is a result of the unique make-up of the Cambodian government, but has also been strongly influenced by all of these external pressures. Thus many actors, including international ones, will be legitimized, or not, by the ECCC. It is a risky venture for all. 


\section{ISSUES AND CHALLENGES - CAN THE ECCC SUCCEED?}

There are many positive effects that could come of the RGC cooperating with the international community on the ECCC, especially if it is seen in the context of a larger transitional justice framework, including reconciliation and healing, and if plans are made early on to optimize the positive legacy. However, there are also serious challenges to be faced, foremost the severe crisis of legitimacy of the judiciary. I now consider two key questions: does the RGC want the ECCC, and can the ECCC assist in national reconciliation? In addition, the healing of Cambodian society in relation to the rule of law is considered. Finally, some challenges are reviewed and the various balancing acts are discussed: between truth, justice, reconciliation and peace; between trials or no trials; and how to 'close the chapter' of this dark period of history.

\section{Views on Transitional Justice ${ }^{22}$ in the Cambodian Context}

This book's Chapter 1 argues that there are three components of legitimacy, the first of which is that 'actions are based on a legal framework, ultimately a constitution, but in a wider sense through the establishment of the rule of law in society'. This chapter reinforces that point: both the international community and the RGC hope that the ECCC will bring legitimacy to the RGC - and that simultaneously the ECCC will also be an important step towards strengthening the rule of law. Until former Khmer Rouge leaders are brought to the ECCC to answer for the disaster of their rule and accountability is sought, impunity remains also in the wider society (but the ECCC is not of course the only means of decreasing impunity, just a necessary pre-condition). And only when these massive international crimes of genocide and crimes against humanity are investigated and prosecuted can Cambodia then enter the community of nations (again, not the only step that must be taken). An idealized ECCC could contribute to improving the rule of law and legal reform by: improving the technical skills of some individuals (judges, police and others); providing a positive example to the morally exhausted judiciary; setting precedents using international law; and improving related institutions such as the Supreme Council of the Magistracy and the Cambodian Bar. These are very tall orders and it will be extremely challenging to get even some of them. However the ECCC must be examined in the larger contextual framework of transitional justice where issues of truth, justice, accountability and reconciliation must be balanced. 
In the thirty years since the end of the Khmer Rouge regime, the world has experienced new genocides and slaughters (Rwanda, Yugoslavia, South Africa, etc) and new and distinctive legal responses have been developed to deal with the aftermath of violence. As countries emerge from periods of armed conflict and mass violence they seek a balance between truth, justice, peace and reconciliation - and there is tension between these concepts. Justice is balanced with political realities and international human rights standards with national realities (as is seen in the compromise of this ECCC mixed tribunal). Transitional justice approaches focus on accountability, and include both judicial and non-judicial responses (Minow 1998). Possible judicial and quasi-judicial mechanisms include national and international trials, truth commissions, civil sanctions or vetting, reparations, and community reconciliation mechanisms. Judicial mechanisms such as trials can serve the following purposes: challenge a culture of impunity; individualize guilt (to avoid an entire group e.g. Khmer Rouge collective guilt); avoid unbridled private revenge; fulfil an obligation to the victims to publicly acknowledge who was right or wrong; and deter or punish (Ea 2003: 11). All of these arguments have been made by various people and reports at various times in support of the ECCC.

Since the 1992-1993 UN intervention in Cambodia, the notion of accountability has changed in international spheres. The peace accords negotiated in 1991 included demobilization and disarmament, repatriation, elections, and human rights, but not accountability. Today, more and more peace processes are starting to include accountability in the agreements, such as those for Darfur, Iraq, Afghanistan, although this is not an easy process. When the parties are still fighting it is often not possible to talk about accountability: amnesty is often the carrot that can make them stop fighting, while trials can encourage more war. In Cambodia, the fighting is now over, but the senior leaders of the Khmer Rouge were presumably given promises when they defected. A few of them are powerful and linked to the current government. Many pressures are weighing against the ECCC, including from some international players. In this atmosphere, accountability through the ECCC remains a real challenge.

While accountability is an important goal, the overall long-term goals of sustainable peace and reconciliation must also be considered; reconciliation has been the stated goal of many. The UN Secretary General's report of October 2004 stated: 'I am aware of the expectation of the Government of Cambodia and the international community that the Khmer Rouge 
Tribunal will contribute substantially to national reconciliation in Cambodia' (United Nations 2004: 5). The goals of accountability and reconciliation are often contradictory and are certainly under-studied. 'There is a lack of discussion in policy circles and the international relations literature of the relationship between mechanisms and desired outcomes in terms of justice and reconciliation' (Lambourne 2004: 6). The ECCC is based on a retributive justice (state-centered) model, while many authors are recently suggesting that restorative (victim-centered) justice may also have an important role to play in transitions (Estrada-Hollenbeck 2001). Thus for individual and societal healing to occur, other complementary processes are needed. '[W]hile justice is necessary for sowing the seeds of reconciliation between former enemies, it is clearly insufficient in itself' (Ea 2003: i). The quest for vengeance must be balanced with forgiveness. Remembrance must be balanced with forgetting, and memories of the past must not overwhelm the present and the future. The issues of punishment, reparations, amnesties and pardons must be examined. The process of the ECCC, although it may help survivors know more about what happened in the past, may neither meet the need to know the full truth, nor to have the crimes acknowledged by the perpetrators. But these details will not be of primary interest to the RGC nor to the main players of the international community, as both seek to 'close the chapter' of the Khmer Rouge period. Thus it is up to civil society through organizations such as DC-Cam, the International Center for Transitional Justice ${ }^{23}$ and others to look at the broader societal issues surrounding transitional justice and reconciliation.

\section{Truth-telling}

The United Nations 'Group of Experts' which in 1997 undertook an assessment of Cambodia's needs post-conflict considered the dual needs for justice and reconciliation. They first recommended an international tribunal, but also a truth-telling mechanism: '... the United Nations should establish an ad hoc international tribunal ... They further recommended that the United Nations, in cooperation with the Cambodian Government and non-governmental sector, encourage a process of reflection among Cambodians to determine the desirability and, if appropriate, the modalities of a truth-telling mechanism to provide a fuller picture of the atrocities of the period of Democratic Kampuchea' (United Nations 31 March 1999: 2). The Documentation Center of Cambodia (DC-Cam) has always focused on truth (searching for the truth is its motto) but it is also increasingly 
emphasizing the importance of reconciliation and healing in its work. In the future it may spearhead efforts to encourage the government, or to organize at DC-Cam a mechanism, to search for greater truth and accountability. However, the RGC's policy has always been only to focus on senior leaders and those most responsible, presumably because some amongst the government fear embarrassment, if not prosecution. They have also said in the past that they fear societal upheavals if victims and perpetrators at all levels were to start confronting one another. ${ }^{24}$ In some of the surveys and reports, a minority of Cambodians have said they want to focus justice mechanisms or at least truth-telling on the lower level cadre who actually killed their family members (McGrew 2000; Ramji 2000; Ea 2003; Linton 2004). More recently some have again reiterated the need for a truth-telling process, but Cambodia may not currently be ready for the societal upheavals which would result from a truth-telling mechanism that went to the very lowest levels (Ramji 2005). Much more study is needed to see if and how such mechanisms could work.

\section{The Policy of National Reconciliation}

Throughout the negotiations, the RGC's policy of 'national reconciliation' has played a role in allowing for politically expedient amnesties or pardons - encouraged by the international community. This policy was announced in 1987 by the PRK in reference to calling for talks with resistance leaders: 'An appeal to overseas Cambodians to support Phnom Penh's economic and national defence efforts and assurances that Cambodians who had served the insurgent factions would be welcomed home and should be assisted in resuming a normal life and in participating in the political process were key features of the policy' (US Government 1990). ${ }^{25}$ Indeed the entire premise of the Paris Peace Agreements was based on ignoring the 'genocidal policies and practices of the recent past'.

Prime Minister Hun Sen has placed a great emphasis on the policy of national reconciliation, and sees the ECCC as a part of a (controlled) reconciliation process: 'The trial of the Khmer Rouge leaders will be a fair ending of its political organization after they were finished politically and militarily. We will not forget about justice as we will never forget about national reconciliation, peace and stability. The two objectives could be compared to heart and lung of every one of us. I.e. we cannot go without either one of them' (Hun Sen 2001). His 'win-win' policy of seeking 'pacification' in the former Khmer Rouge areas is similar in welcoming low 
level cadre into the fold. ${ }^{26}$ In an information booklet on the ECCC prepared by the Royal Government Task Force on the EC, national reconciliation is referenced several times: 'the policy of national reconciliation is still in place' (Secretariat of the Royal Government Task Force 2004: 6). Furthermore, the booklet states that 'In the spirit of achieving justice, truth and national reconciliation, the Cambodian government and the UN decided to limit prosecutions to the senior leaders ...' (Ibid.: 6).

The tension between the carrots of amnesties and the sticks of trials has been a balancing act in which many parties have participated. The RGC's promises of amnesties to defectors in the name of peace and national reconciliation included both the individual pardons engineered by Prime Minister Hun Sen for former Khmer Rouge leader Ieng Sary, and the general offer to defectors through the 1994 Law outlawing the Democratic Kampuchea group. The issue of the amnesty for Ieng Sary is quite contentious and is even referenced in the ECCC law as the UN wanted to ensure that no justified prosecution could be avoided. At this point, upholding this particular amnesty could actually de-legitimize the ECCC. There appears to be more than adequate evidence against him so when Nuon Chea was arrested and not Ieng Sary there were many grumblings. Once his (and his wife Ieng Thirith's) arrest did occur the reaction from the Cambodian public was quite positive - this step seemed to have passed a threshold of legitimacy for many Cambodians as they knew that his close ties to Hun Sen may have protected him. Now, it seemed that the trials might even happen. ${ }^{27}$

The words 'policy of national reconciliation' are used freely by government leaders, with no real attempts to define the term, nor to undertake a real process to include the views or participation of civil society. Such lack of effort to search for any accountability, truth, apologies, or forgiveness, could possibly lead to dissatisfaction in the future. Cambodians have made it clear that they want to know who did what and why, and a tribunal will only at best be able to answer some of these questions. Thus, the broader view of transitional justice in post-conflict societies as described above, which could include some additional truth-telling mechanism, may serve Cambodians' need for a larger societal reconciliation.

\section{The Judiciary}

In the reconstruction of post-conflict countries 'good governance' which includes the restoration of the judiciary and the legislature is crucial. Unfortunately in Cambodia the legal system is riddled with problems. A 
2004 World Bank report states '... the central message which runs through this report (and which is explicit in the Government's Rectangular Strategy): namely, that Cambodia will not be able to escape poverty and marginality unless it achieves good governance (110)'. The logic then follows that since the RGC wants to re-enter the world community as a full member, escaping poverty and marginality, then it must ensure good governance, including the rule of law.

Since so many Cambodians perished under the Khmer Rouge and in particular educated people, the dearth of educated professionals is also affecting the establishment of the rule of law and the legitimacy of the ECCC - only a handful of lawyers survived the Khmer Rouge period. The approximately existing 200 judges and 275 lawyers lack adequate training (Un 2004: 182-184). As noted in this volume besides being plagued with patron-client networks, corruption, and a lack of capital and human resources, today's Cambodian judiciary was originally designed with Soviet and Vietnamese assistance, and was not independent of the executive - in fact it was (and remains) a tool of the powerful leaders, all within the CPP. The deepest flaw in the mixed ECCC solution is that the Extraordinary Chambers are based within these deeply dysfunctional Cambodian courts, causing great risks for miscarriages of justice. The rule of law is not evenly applied in individual courts, and impunity is rampant: for example several sons of high ranking officials have escaped justice or had only minimal sentences imposed for such serious crimes as murder and manslaughter (USAID and Casals \& Associates 2004: 9). Impunity is a complicated web and often involves the judiciary and executive - including the ministries of interior and justice, the ruling party, the courts themselves and the police and other powerful people in society including business persons. Any and all of these forces can act independently, or can conspire to influence a case, which often results in impunity. Court officials may be afraid of unfair punishment, random disciplinary actions or even security problems if they do not follow instructions they receive by telephone. Court officials are afraid to issue warrants to call as suspects or witnesses high ranking government officials (Un 2004: 205). Many observers are sceptical that government officials or high ranking 'insider' witnesses, who are needed to give evidence, will actually cooperate with the court.

Although the Supreme Council of the Magistracy is supposed to discipline wayward judges, laws related to the administration of the judiciary have not been passed, and disciplinary measures used now are random, secret and 
politically motivated. Complicated relationships between the courts and the police further complicate the quest for justice in Cambodia. Although the judicial police should be under the prosecutor and investigating magistrate during investigations, in reality the two institutions are both vying for power and rarely cooperate. The ECCC has national investigators in both the prosecutors' and investigating magistrates' offices, and there are judicial police under the direction of the Ministry of Interior on security detail. A survey by the Center for Social Development found that the public perceives the courts as one of the country's most dishonest institutions, just behind the traffic police and the tax authority (Chhim 2005). And in a survey on the KRT (i.e. ECCC) 41 out of 48 respondents said that they did not trust the courts (McGrew 2000). This is a major reason why Cambodians in this survey and many others preferred an international tribunal. Recently, anecdotal evidence, including random questions to the 'person on the street' in various news articles, indicates that there is less hope for an independently functioning tribunal than there was five years ago. All this challenges the legitimacy of the ECCC.

The question of which accused persons will be brought to the ECCC and which victims will be represented is another challenge. Almost every Cambodian can be considered a victim in some ways - having lost family members or suffered great deprivations during the Khmer Rouge period. However, will suspects with strong patronage networks escape the attention which their cases deserve? Although the ECCC has made huge strides in legitimacy by arresting four senior leaders, especially Ieng Sary who many thought would escape justice, will any other senior leaders really be arrested and brought to the court? It is feared that those with 'k'saie' or strong political ties or connections, some named in Heder's 'Seven Candidates for Prosecution' (Heder 2004), will escape justice - either by not being prosecuted or by judges being pressured politically to find certain people not guilty. Bribery is also another fear. Although most of the 'seven candidates' are alleged not to have great cash reserves, Ieng Sary is said to have several houses and has benefited more than his former colleagues from the gem and logging trade. It is not at all clear what funds the accused may have if any.

Although the references to reparations in the Khmer Rouge law and agreement are vague, there is a bit more clarity in the internal rules. Judges may apply reparations for civil parties (victims) to the proceedings, to be borne by convicted persons. These reparations are to be moral and collective 
(rather than individual) and could take many forms such as services (schools, scholarships, hospitals, or mental health services), memorials and museums, or days of commemoration. Several international NGOs are working with the ECCC and the local NGOs to assist them to formulate some appropriate possibilities, based on experiences in other countries. ${ }^{28}$ If reparations were to be applied in a meaningful way for the public, this would greatly add to the legitimacy of the ECCC.

\section{LEGACY AND LEGAL REFORM}

With the growing evidence from international tribunals indicating that a legacy can be enhanced and planned for, the ECCC is ideally placed to think ahead so as to optimize the positive effects of the process, thus increasing its (and the RGC's) legitimacy. The specific legacy of the trials can include leaving behind physical materials (buildings, vehicles, books, computers); improving the professional skills of Cambodian judges and other court staff or related personnel such as police; improving the rule of law by increasing the capacity and integrity of individual judges who work alongside international judges, affecting local jurisprudence, legal practice and ideally improving institutions such as the Supreme Council of the Magistracy and the media. With additional ancillary services and projects other positive effects could be: an increased knowledge of history and 'truth' needed for reconciliation via museums, memorials, oral histories, the arts; the education of the youth (who are relatively ignorant about the Khmer Rouge period - many refuse to believe it happened); improved interpretation skills for trials (not necessarily just legal translation); and expanded mental health services.

However, the hopes to build a positive legacy exist in the context of a long history in Cambodia. In order to address the problems with the judiciary, there have been many attempts to reform, with the Council for Legal and Judicial Reform finally making some small progress in the last few years. Unfortunately, it is very difficult to address the entrenched corruption and political influence unless the entire political system is changed and revamped. 'The Cambodian elite have made conscious political calculations to suppress the judicial system from becoming effective and independent. For the elite to do otherwise would jeopardize their grip to power - a form of control best served by an erratic, corrupt and politically subordinate judiciary. This is evidenced by the government's consistent inaction toward 
judicial reform despite domestic and international outcry' (Un 2004: 229). Several other authors have also noted that the problem with reforming the judiciary is not so much trying to improve capacity (though that is needed as well) but that there is no political will to change, or donor initiative to ensure the difficult changes (Urs 2007; Henke and Chhim 2006).

Efforts were made in the design of the ECCC to help to neutralize any malign influence, essentially through the structure of the courts and decision-making processes and by the pairing of international and Cambodian judges, prosecutors and other staff. Much faith is placed in the presence of the international staff and judges and the Deputy Director of Administration who controls the UN Trust Fund, ${ }^{29}$ but as noted above the administration of the ECCC has already been plagued with problems. Although it is hoped that the ECCC can serve as an example of a functioning court to positively influence the other courts in Cambodia, substantial changes in the ECCC are still needed. This cannot happen unless there is a concerted effort by donors, as well as by NGOs, the media and other members of civil society, to provide adequate monitoring, support and accompanying services (such as outreach and mental health).

\section{DOES THE CAMBODIAN GOVERNMENT WANT THE ECCC?}

This section speculates on the various opinions on the RGC's views on the ECCC. Some observers feel that because Prime Minister Hun Sen has fought the Khmer Rouge since he left the movement in the late 1970s, he still has a personal vendetta and wants to bring certain leaders to court. Others argue that he himself does not really want the ECCC; he only wanted it because it was a tool to bring down the Khmer Rouge, so it is now no longer necessary. Some observers think that the ECCC is only happening because of international pressure that the public efforts the RGC are making towards the ECCC are just a show, and that they hope that these efforts will be seen as sufficient to gain the RGC legitimacy (without actually decreasing RGC control of government). Other sceptics argue that Hun Sen and the RGC have no intention of letting this trial go forward, and that the many starts and stops are indications of the lack of political will. Other pressures could be influencing Hun Sen, including various members of the international community, the military or other political parties who made deals with the CGDK and Khmer Rouge in the many years of fighting along the border, as well as Ieng Sary who must have made a deal for his 'defection'. 
In any case, there is great concern amongst donors and others that the government has not exhibited sufficient commitment to the process of the ECCC: one of the main problems in 2005 was the budget. In spite of the millions of dollars lost in corruption every year, the RGC only offered US $\$ 1.5 \mathrm{~m}$ out of the US\$13.3m Cambodian part of the ECCC budget, and requested the rest from donors. When it was suggested that the business sector and individuals could contribute to the ECCC, some senior government officials had a very negative reaction and insisted that donors provide the funds instead. Many interpret this debate as yet another stall tactic from a RGC that does not really want this tribunal to happen. Others believe that the government position is that if the international community is pushing for this tribunal then they should pay for it, especially in light of the previous international support for the Khmer Rouge. 'However, despite the fact that we were fully entitled to prosecute the Khmer Rouge in a national court, we sought international involvement in the process, preferably through the United Nations. Why? On the one hand because we were all too acutely aware of the weaknesses in our judiciary, and we wanted help to make certain this trial was able to meet internationally accepted standards. On the other hand, and let me be frank here, we felt that it was important for the international community to share in carrying out this task in order to clear its own record on previous support for the Khmer Rouge' (Sok An 2002: 7).

The RGC is gambling a great deal on the ECCC. If it succeeds (or enough attempts are made or are seen to be made towards the ECCC on the government side) the trials themselves and the achievement of accountability can then be a major step towards legitimacy: that is one reason why the process is being so tightly internally controlled. Another main reason for the control is to protect certain individuals who are now part of the government who could either be implicated or embarrassed by their testimony - or who possibly fear being accused or indicted. A third major factor in the need to control the ECCC undoubtedly includes pressures from outside parties, in particular China, who have openly expressed a lack of support for the ECCC. This need by the RGC to control the process is actually in contradiction with real legal reform and the rule of law, and creates a challenge to observers and donors: monitoring of the ECCC should be linked to benchmarks of wider legal reform and the UN should develop clear and timely criteria for withdrawal if international standards are not met. Several NGOs have been involved in developing 
benchmarks and have done this in dialogue with the ECCC, which is a very good first step, but the implementation is key.

In addition to the success (and the public perception of the success) of the trials and process, the absence of implication or embarrassment of RGC leaders, and the maintenance of security of all participants, internal legitimacy also depends upon activities and projects that need to take place around the ECCC, in particular the outreach programme. Although outreach should be a major programme of the ECCC, it is woefully underfunded, so NGOs are playing a crucial role in sharing information and expanding the public dialogue about the trials and justice, as well as the many other related topics such as truth, reconciliation, forgiveness and reparations. It thus behoves the RGC and the ECCC to work closely with NGOs to maximize the positive impact - and so far the coordination has been good. External legitimacy also depends upon an effective outreach and public relations campaign - if the Cambodian public disregard or worse criticize too strongly the ECCC the RGC could suffer from negative publicity.

In any case, it appears that the Prime Minister would benefit if, at the end of the process, he could say to the international community, 'We did what you wanted, now we can play in the international playing field.' The RGC could then 'close this chapter' in history and move on. Some individuals in the government, civil society and the donor community are hoping that the ECCC can help improve and thus legitimize the judiciary so as to promote the rule of law and provide a framework to work on many problems such as poverty, corruption, land grabbing and impunity. These are extremely ambitious goals which will need close attention at every step along the way. Others fear that the ECCC could actually damage the rule of law by prosecuting only senior leaders and sparing those at lower levels and those who actually did the killing (Urs 2007). In any case it is more likely that only small steps in promoting the rule of law can be made, if at all, in the context of the abysmal record of judicial reform to date. However, the ECCC still provides an important opportunity for potential reform and all stakeholders should work towards that goal. First steps have been made as individuals in NGOs and in the court have been discussing the legacy aspects and it is hoped that more concrete steps will be made in the near future. 


\section{Can National Reconciliation be Reached through the ECCC?}

The RGC has often referred to the purpose of the ECCC as leading towards national reconciliation. 'By the end of December 1998 we had managed to put an end to the Khmer Rouge political and military structure, and were faced with the twin tasks of national reconciliation and justice' (Sok An 2002: 3). The UN Secretary General's reports on the KRT (i.e. ECCC) in October as well as many other reports and much of the current literature reason that justice through trials brings reconciliation (United Nations 2004). In this book's Chapter 1 the crucial importance of reconciliation is noted in a successful reconstruction process, as is the importance of building trust. The ECCC if properly conducted could in fact lead to national reconciliation and trust-building. But it is important to point out that this will not happen automatically. Only with a specific process involving civil society at all levels can there be any hope of moving towards reconciliation and trust. Much more public discussion is needed. A few studies have been carried out which look at various aspects of reconciliation (McGrew 2000; Ramji 2000; Linton 2004; Etcheson 2004) but these need to be built upon and explored nation-wide. 'The South-African experience teaches us that veritable national reconciliation requires knowledge of the truth ... However, every state faced with this problem must remain free to choose the means of discovering it' (Boyle 2004: 43).

A conflict-analysis component is a crucial part of conflict resolution or transformation: as conflicts are transformed, reconciliation can follow. The ECCC should contribute to conflict analysis, as a historical record should be - at least in part - provided. Many Cambodians want to know why the KR did what they did, and why so many deaths resulted (McGrew 2000; Ramji 2000; Linton 2004). Although a truth commission and other processes are better suited to deal with the why questions, the ECCC should shine some light on history, and would open discussions which can hopefully move towards a larger process of national reconciliation and healing.

\section{HEALING CAMBODIAN SOCIETY}

This book's Chapter 1 suggests that in post-conflict reconstruction there is a 'necessity to "invent" society, while at the same time rehabilitating it'. In the case of dealing with mass violence, this need could not be clearer: how will society recover and adjust after 1.7 million deaths and with the presence of some of those involved in the former regime living at all levels: from 
villages to within the current government? The entire social infrastructure of Cambodia (education, health, judiciary) was destroyed under the Khmer Rouge, and rebuilding is slow. Family members were separated, almost everyone saw people killed or at least led away to be killed, people had to write and re-write biographies and confessions, and Angkar's paranoia encouraged people to spy on their families and friends. All of these factors (as well as newer pressures on society related to globalization and the search for wealth) have resulted in a lack of trust in society and a residual sense of fear and insecurity, which call for major changes in society, not just rebuilding but formulating some things a new. These factors will affect the trials, and must be accounted for when planning for witness participation, outreach, legacy, indeed for all aspects of the ECCC. A recent study in the large Cambodian community of Long Beach California indicated that nearly two thirds of Cambodians suffer from post-traumatic stress syndrome (McFadden 2005). The process of gathering testimony and making results public will have a psycho-social effect, as Cambodians will re-live their painful individual and collective pasts. So far, the long negotiations and the apparent stalling by the RGC are already putting this trust-building process on shaky ground. Thus the ECCC is operating in a socially sensitive environment which it must take into consideration. At the same time, the ECCC could possibly serve as a tool for healing, but only if psycho-social services are offered ${ }^{30}$ and reconciliation and the healing of society are considered as goals.

Establishing the rule of law is also crucial to restoring society. 'The rule of law is, after all, the indispensable platform for development ... must be rooted in the social and political context of a nation. It is an expression of the fundamental social contract arrived at when peace replaces and people find the terms on which they can live together ...' (Malloch Brown 2004). To achieve internal legitimacy through the trials, the RGC and the ECCC must then make sure to include the Cambodian public in the deliberations so that linkages are made between the ECCC; perceptions of the ECCC by the public; Cambodian cultural aspects related to justice, reconciliation and the ECCC; and the long term societal needs related to reconciliation. "The rule of law is not something that exists "beyond culture" and that can be somehow added to an existing culture by the simple expedient of creating formal structures and reviewing constitutions and statutes' (Ehrenreich Brooks 2003: 5). Although the original UN Group of Experts report recommended an international tribunal outside Cambodia, having 
the trial in Cambodia should actually better serve Cambodian society's interests and increase local acceptance.

Western values related to international law should be explored in the context of Cambodian values for a truly useful (and legitimized) ECCC. An important aspect of Cambodian values is related to the state religion of Buddhism. Some Cambodians quoted in surveys as well as some researchers have suggested that an international tribunal does not fit the predominantly Buddhist view of Cambodians, that in fact amnesty and truth-seeking are more important than Western concepts of justice and retribution (Harris 2005; Ramji 2000). This does not necessarily negate the goals of an international tribunal, as most surveys do indicate that most Cambodians do want an international tribunal, but merely indicates that more research is needed and that outreach programmes need to take into consideration the relationship between religion and the ECCC. As there is now experience of other international and hybrid tribunals, lessons learned from them should be applied to the ECCC within the larger experience of transitional justice and long-term reconciliation and healing. Many rituals and activities related to Buddhism and to other aspects of culture need to be explored for their possible social healing effects: memorials, museums, storytelling, art, theatre, music, dance, poetry, religious rituals, official days of remembrance (McGrew 2000; Etcheson 2004).

Several authors have written analyses of the origins and outcomes of the Khmer Rouge (Becker 1986; Kiernan 1997; Chandler 1999 and 2000; Heder 2002; Short 2004; Hinton 2005), and some Cambodians (Pin 1987; Szymusiak 1999; Ung 2000; Seng 2005) have written about their experiences under the Khmer Rouge. However, there is little discussion of these books in Cambodian society and little historical analysis by Cambodians. Only recently have the Becker, Chandler and Ung books been translated into Khmer by DC-Cam. ${ }^{31}$ It is a common view that 'Khmer couldn't have killed Khmer - a foreign power must have been behind Pol Pot' (interview with human rights NGO staff 2005; Ramji 2000) $)^{32}$. A successful ECCC could contextualize Cambodians' historical memory, as the voices of Cambodians will predominate in the process.

Some more recent initiatives show that the ECCC could also play an important role in re-inventing Cambodian society. Public forums in March 2006 in Pailin organized by the Center for Social Development showed that some Cambodians were calling for village-level commissions to feed into a national process to find a common history. These lofty goals can be 
reached, only if the ECCC is conducted well and to international standards, and includes inputs from Cambodians, with adequate outreach, appropriate expectations and sufficient services, especially in terms of mental health care including trauma counselling and victim and witness support and protection.

\section{CHALLENGES FACING THE RGC AND THE ECCC}

It is now almost thirty years after the end of the Khmer Rouge regime, and some of the leaders are beginning to die off or are becoming old and infirm. Witnesses too are ageing and the documentation of evidence is insufficient. Reconstructing what happened under the Khmer Rouge regime will be difficult, given the great secrecy of the regime and a lack of records. With the massive population movements during the Khmer Rouge period, it is difficult to trace people and names have been changed. Furthermore, 350,000 returnees were repatriated during UNTAC and are still not fully integrated into society. Some could be witnesses, and many came from former Khmer Rouge areas where they are living somewhat separately from the rest of the country. The RGC's close ties with many key actors in the Khmer Rouge débâcle (China, Vietnam and senior Khmer Rouge leaders) will challenge the conduct of a fair and successful ECCC. In addition, it is not clear that the government really wants a trial.

There are many issues that have been raised by those monitoring the process of developing the ECCC. To date the government has addressed a few of the civil society concerns, but the long delays and lack of dialogue and transparency have further shaken the confidence of the population in the process. If civil society is not brought in closer to the debate around the ECCC, it will not be possible to achieve the goals of seeking justice, nor of working towards national reconciliation. Burke-White argues that the views of Cambodian civil society are crucial in the administration of justice in Cambodia. He suggests that the individual should be the focus because restorative justice should have primacy over retributive justice (Burke-White 2005: 2).

\section{The Balancing Acts}

My previous pages have described some of the historical balances that preceded the creation of the ECCC: balancing between different actors with different interests; balancing between holding the tribunal or not (the latter 
also a risk); balancing the content/nature of the ECCC; and balancing the outcome. These various balancing acts by the RGC are extremely delicate and complicated - the task before Prime Minister Hun Sen is fraught with pitfalls and is resulting in limited possibilities to act as the ECCC develops. The pressures on him both internally and externally are many and deep.

Trials normally emphasize justice, not truth and reconciliation. The full truth is certainly not a priority of the RGC, as it fears light shed on the involvement of their various members (this includes not only the ruling CPP party, but also SRP and FUNCINPEC members who worked under the CGDK at the Thai-Cambodian border). The RGC wants to keep tight control on the ECCC. Although it thinks it can do so because the trials will be held within the Cambodian courts, international experts from other tribunals have other assumptions - that once under way the court will take on a life of its own and will continue independently. This is actually starting to happen though in very small measures. In any case, the bottom line is that the RGC can easily find a way not to cooperate with the ECCC, be it a recalcitrant prosecutor or investigating judge, problems with budget or implementation, or claims of interference with national security. Given the current climate of impunity and control, the RGC will do everything within its power to prevent the ECCC from getting out of control.

\section{CLOSING THE CHAPTER}

The idea that the ECCC could serve to 'close the chapter' has been mentioned by many: 'In holding this trial, we will carefully balance, on the one hand the need for providing justice to our people who were victims of this genocidal regime, and to finally put behind us the dark chapter of our national history with, on the other hand, the paramount need for continued national reconciliation and the safeguard of the hard gained peace as well as national independence and sovereignty which we value the most' (Hun Sen 1999). Indeed trials in general can serve the purpose of allowing victims, perpetrators and others to go on with the lives, once the verdicts are known. Although of course not everyone is happy with all verdicts, once a verdict is made (and if the process is seen as fair) then there is for most some feeling of closure. However there are certainly varying views in this case of what closing the chapter means. Most RGC leaders would consider that once the trials are over, any trials no matter how flawed, no more discussion would be needed. Many others however do not feel satisfied with only trying seven 
senior leaders. There could be cries for the prosecution of other lower level leaders. And as is already happening all over Cambodia, talk of the ECCC itself raises old memories and starts discussions - where communities are dealing with the perpetrators living amongst them. Most Cambodians also appear to assume that the major alleged perpetrators will of course be found guilty - if there are any 'not guilty' verdicts there will certainly be confusion. There is little understanding of defence rights in Cambodia. These issues reinforce the importance of an early and broad outreach program, so that everyone understands the trial process and defence rights, and that expectations are realistic. ${ }^{33}$

Research done with Cambodians in Canada has led to some interesting conclusions. 'Though a tribunal would have value in establishing rule of law in Cambodia, what would matter to Cambodian people, at least here, is that it would provide legitimacy to their experiences to the wider Canadian and global society. This legitimate recognition could then enable them to speak out publicly, something they are afraid to do now and to begin to put the past in the past' (McKinlay 2005). Cambodians say they are tired of meeting people overseas who immediately connect them with the Khmer Rouge horrors, and not with any other aspects of themselves or of Cambodia. With a well-run civil parties process through the ECCC Victims Unit, and an opportunity for victims to make complaints and have those complaints heard, they can feel acknowledged, which can lead to healing - and ultimately legitimacy. More study is needed on the links between personal legitimacy and the validation of the past and the suffering that can come with trials, with national-level legitimacy. It could be that both the RGC as well as individual Cambodians could benefit from legitimate trials and a truth-telling process. The ECCC could be one aspect of 'closing the chapter' so that Cambodians can put more focus on reconstructing society. But the emphasis is on the word could - there are a myriad of obstacles to be overcome before the ECCC can be considered a success.

\section{AFTERWORD}

Although it is not clear that either the UN or the RGC are sufficiently motivated to carry out the ECCC to the finish, it is argued that a successful, fair and independently run tribunal for the Khmer Rouge could result in greater stability and enhanced legitimacy for the Royal Government of Cambodia - but only if international standards are maintained, civil society 
consulted and adequate support services for victims and witnesses, outreach and mental health services are provided. In other words, the components of a post-conflict reconstruction process such as reconciliation and building trust cannot be implemented unless there is an inclusive and concerted effort carried out jointly by the RGC, the international community and Cambodian civil society.

The challenges to achieving a fair and independent ECCC are: unclear government motivation, influence of foreign governments, and a weak judiciary. Others include lack of sufficient funding to maintain international standards; historical delays by the UN in starting operations; short period of operation (three years) - though extensions are already being discussed; nontransparent planning and selection of judges, prosecutors and staff; unclear rules of procedure; unclear roles of the pre-trial chamber, the constitutional council, the prosecutor and investigating magistrate. However, the most serious issue is the controversy over the design of the ECCC, as part of the Cambodian court system, with a majority of Cambodian judges in a seriously flawed judiciary. Also, by pre-determining that senior leaders are most responsible, and focusing mainly on command responsibility, human rights norms of presumption of innocence are challenged, not to mention ignoring the issue of the thousands who have killed directly. In a country where the rule of law is precarious and the courts corrupted and incompetent, this message has important (negative) impact.

Can the RGC gain legitimacy from conducting the ECCC with international assistance? And does it want to? This chapter has attempted to answer these questions - and the answer is yes and no. Yes, with a properly conducted ECCC with international standards and no untoward interference by the authorities, legitimacy can be gained, the chapter can be closed (at least part way), impunity addressed and the rule of law improved. Internal legitimacy can be increased with the final defeat of the Khmer Rouge by the government, legal reform, and ideally increased trust between civil society and government. But with the RGC's dismal human rights record and problems with the rule of law, there are many hurdles to vault. It is not clear that the RGC - all parts of it - really have the political will to bring the ECCC to a successful conclusion. And there are outside influences that are pushing against it. However, since the negotiations have finally resulted in the establishment of the ECCC, justice seems closer than ever. It is important now that civil society and the donors maintain a vigilant watch on the process to ensure that measures are built in to continually 
evaluate, including benchmarks or warning signals. If the benchmarks are not met, the UN must be prepared to pull out. A parallel but coordinated process is needed to evaluate, design and find funding for related projects on reconciliation, trauma-healing, trust-building and how to improve the legacy and promote the rule of law. The ECCC should be seen as only one step in the broader exercise of transitional justice which should be discussed and decided by Cambodians at large, not a few elite politicians and the international community. These are all important aspects to complete the full picture of post-conflict reconstruction.

\section{NOTES}

1 See http://www.eccc.gov.kh/english/default.aspx. The Extraordinary Chambers in the Courts of Cambodia (ECCC) was originally known as the Khmer Rouge Tribunal (KRT) and also later as the Extraordinary Chambers in the Courts of Cambodia for the Prosecution of Crimes Committed during the Period of Democratic Kampuchea. Since the arrival of the United Nations Deputy Administrator in February 2006, the formal name of the institution is the Extraordinary Chambers in the Courts of Cambodia (ECCC). In this paper the newer official term ECCC will be used.

2 This quote is from their defence lawyer, Yuos Por (page 256), and Dith Munthy states 'I declare that I fully agree with the arguments put forward by my comrade Lawyer Yuos Por with regard to the expansionist-hegemonist-Peking reactionaries whose blood-stained hands actively pushed, stimulated, and helped Pol Pot and Ieng Sary to carry out the Maoist doctrine in our country' (page 261). Dith Munthy is the current President of the Supreme Court, key member of the Supreme Council of the Magistracy, co-chair of the Council for Legal and Judicial Reform, and previous candidate for KRT judge, in spite of his biased involvement in the 1979 trial.

3 US officials John Kerry and David Scheffer have offered various compromise solutions including those for the supermajority and pre-trial chamber.

4 Letter from the RGC Co-Prime Ministers Norodom Ranariddh and Hun Sen to UN Secretary General Kofi Annan, 21 June 1997. The Co-Prime Ministers did not actually write the letter themselves, but they agreed to sign a letter written for them by the UN Centre for Human Rights.

5 Royal Government of Cambodia Task Force on the EC, see www.cambodia.gov.kh/ $\mathrm{krt} /$.

6 A revised budget of more than 100 million was being considered in early 2008, although the ECCC (in particular the Cambodian side) has been plagued by allegations of corruption and incompetence.

7 See www.ai.org, www.hrw.org, www.dccam.org, www.justiceinitative.org and for CHRAC, http://www.ewmi-praj.org/partners_pro/our_partc.htm.

8 See http://www.eccc.gov.kh/english/default.aspx for lists of judges, staff, decisions, internal rules, etc. 
9 For example, to decide to convict an accused person, four of the five judges must agree - the majority of three, plus one. This formula requires that at least one international judge will have to agree with each decision, which was a compromise solution that is supposed to ensure international involvement at all levels. Thus the selection of all judges, both Cambodian and international, is crucial. Unfortunately, the process was not transparent and without clear criteria, increasing the chances that the trials can be subject to political interference.

10 'For the purpose of drafting a budget proposal, a range of five to ten indictees was assumed by both parties, but this figure could change depending on the investigative and prosecutorial strategy that the future court may wish to adopt.' From the United Nations: Highlights of the Noon Briefing, by Fred Eckhard, Spokesman for the Secretary-General of the United Nations, UN Headquarters, New York, Wednesday, 17 December 2003.

11 See John Hall, Letter to the Editor, Asian Wall Street Journal, 21 September 2007. For a full copy of the audit see: http://www.eccc.gov.kh/english/cabinet/files/auditReports/ oapr_audit_report.pdf.

12 See OSJI, 'Corruption Allegations at Khmer Rouge Court Must Be Investigated Thoroughly' 14 February 2007, http://www.justiceinitiative.org/db/resource2?res_ id $=103627$.

13 Peou (1997) argues that domestic pressures are more important than external forces in determining foreign policy.

14 See AFP, 'Ex-King urges cremation of Khmer Rouge victims, 20 July 2007, http://www. nytimes.com/2006/07/20/world/asia/20cambodia.html?_r=1\&oref=slogin\&pagewant ed=print.

15 Macan-Markar, Marwaan, 'Will Sihanouk appear at Khmer Rouge trials?' IPS, 10 September 2007, http://ipsnews.net/news.asp?idnews=39198.

16 See also: Documentation Center of Cambodia survey of 35 Cambodians, June 1997, www.dccam.org; written survey of 48 Cambodians and focus groups and individual interviews of 50 additional Cambodians; IFFRASORC (Institute Français de la Statistique, de Sondage d'Opinion de Recherche sur le Cambodge, national survey of 1,503 Cambodians, 1998; Cambodian Human Rights Action Committee, petition calling for KRT signed by more than 100,000 Cambodians in 1999; Cambodia Daily, informal survey of 24 rural Cambodians, 12-13 January 2000; Center for Social Development undertook three public forums to discuss the KRT in 2000, see National Issues Forum Report 'The Khmer Rouge and National Reconciliation', Battambang 27 January 2000; Reports on DC-Cam nationwide survey distributed through monthly magazine, between January and September 2002, 712 respondents; Khmer Institute of Democracy, 'Survey on the Khmer Rouge Regime and the Khmer Rouge Trial', www.dccam.org; KID, October 2004, www.online.com.kh/users/kid, conducted 536 interviews.

17 See multiple references to Amnesty International, Human Rights Watch documents, and Cambodian Human Rights Action Committee.

18 See www.dccam.org.

19 In presentations given at the Open Society Justice Initiative by the author from 2004 to 2005 , audience members invariably stated that they wanted to know who was behind the Khmer Rouge: primarily China, although sometimes Vietnam. 
20 Internal US domestic politics has restricted US aid to the Hun Sen government and participation with the KRT, due to strong US expatriate Cambodian support to the opposition Sam Rainsy party. A strong US lobby still restricts ties to Vietnam and the RGC (because of its relationship to Vietnamese) as there is remaining antipathy against the Vietnamese after US experience in Vietnam in the 1960s and 1970s. In late 2007 the restrictions were in the process of being loosened.

21 Thus the possible influence of China against the ECCC could be strong - balanced against the large aid packages offered by Japan.

22 This section is a slightly revised version of one included in a booklet on the ECCC published by the Open Society Justice Initiative.

23 See www.icjt.org.

24 In the 1990s there were many statements both by the RGC and others that if there were a trial the Khmer Rouge would return to the battlefields: these were referred to in the 1999 UN 'Group of Experts' report noting '... the Government of Cambodia ... cautioned that any decision to bring Khmer Rouge leaders to justice must take account of Cambodia's need for peace and national reconciliation, and that, if improperly conducted, the trials of Khmer Rouge leaders would create panic among other former Khmer Rouge officers and rank and file and lead to a renewed guerrilla war' (United Nations 1999: 2). To reassure the rank and file, the RGC's policy of national reconciliation has been disseminated in the former Khmer Rouge strongholds of Pailin and Anlong Veng, to assure that lower level cadre that they would not be the target of these prosecutions. The RGC, under this policy, has had to delicately balance the call for justice with peace and stability. In the political climate of the last 25 years it was not seen as a possibility by the ruling party leadership to bring to justice lower level cadre, nor to set up a truth commission. They feared such processes could disrupt the fragile peace or more importantly interfere with the leader's power base. Ironically, while these arguments had a certain ring of truth to them when the negotiations for the trials started, now they seem increasingly to be more of an excuse not to start a major process with uncontrollable dimensions.

25 Stated on 27 August 1987, see http://countrystudies.us/Cambodia/86.htm. The policy was then confirmed by the Coalition Government of Democratic Kampuchea (CGDK) on 31 October that a 'clarification on national reconciliation policy' had been signed by all three resistance leaders.

26 Hun Sen's ‘win-win' policy however 'is not a surrender or a confession but an obligation to be fulfilled by all Cambodian sons and daughters in joining efforts to put an end to the war which the previous generations started' (Hun Sen 1998).

27 When criticizing the RGC for foot-dragging on the ECCC it must not be forgotten that these offers of amnesty were encouraged by various members of the international community at various times in the name of international peace and stability.

28 This includes the International Center for Transitional Justice. See www.ictj.org and www.redress.org.

29 The Deputy Director, Ms. Michelle Lee, will be retiring in June 2008, and it is hoped that a replacement can arrive early in order to avoid gaps in coverage.

30 The local NGO Transcultural Psychosocial Organization (TPO) has been in consultation with the ECCC to provide some services, but mental health services in general in Cambodia are totally inadequate and it is already noted with the increased 
outreach around the ECCC that the needs are increasing. See http://www.tpocambodia. org/; see also Social Services of Cambodia.

31 Former Khmer Rouge Khieu Samphan also wrote his viewpoint of what occurred during the years of Khmer Rouge rule, and this has been published in Khmer, French and English, as well as another history book published in late 2007 in Khmer.

32 Although I quote a single human rights worker here, in the public discussions on the KRT (i.e. ECCC) held by Open Society Justice Initiative and other public forums attended in the last two years, in every session this same question is raised, often repeatedly.

33 For example the word genocide has been used constantly for 30 years to describe Khmer Rouge crimes, while using the legal definition it is not clear that the crime has occurred. If defendants are found innocent of genocide, the Cambodian public will be very confused.

\section{REFERENCES}

Adhoc, Licado and Human Rights Watch (1999) 'Impunity in Cambodia: How Human Rights Offenders Escape Justice’. Report by Adhoc, Licado and Human Rights Watch, Vol. 11, No. 3.

'Agreement between the United Nations and the Royal Government of Cambodia concerning the prosecution under Cambodian law of crimes committed during the period of Democratic Kampuchea'. NS/RKM/0801/12, signed 6 June 2003, passed by the National Assembly on 4 October 2004.

Amnesty International (1998) 'Cambodia: The Death of Pol Pot'. ASA 23/15/98, 16 April. Available: www.ai.org.

- - (1999) 'No solution to impunity: the case of Ta Mok'. ASA 23005199, 22 April.

- - (2000) 'Law and order - without the law'. 1 March.

- - (2002) 'Cambodia: Special Khmer Rouge tribunals in Cambodia - Justice is not served by diluting international standards'. ASA 23/012/2002, 17 December.

- - (2003) 'Cambodia: Amnesty International's preliminary views and concerns about the draft agreement for the establishment of a Khmer Rouge special tribunal'. ASA 23/003/2003, 21 March.

- - (2003) 'Amnesty International's position and concerns regarding the proposed “Khmer Rouge' tribunal”'. 25 April.

Ashley, David (1998) 'Between war and peace: Cambodia 1991-1998'. In Safeguarding Peace Cambodia's Constitutional Challenge. London Accord: Conciliation Resources, Issue 5, November.

Becker, Elizabeth (1986) When the War was Over: Cambodia and the Khmer Rouge Revolution. New York: Simon and Schuster.

Boyle, David (2005) 'Establishing the Responsibility of the Khmer Rouge Leadership for International Crimes'. Yearbook of International Humanitarian Law, Vol. 5, TMC Asser Press, pp. 167-218. 
Brinkerhoff, Derick W. (_005) 'Rebuilding Governance in Failed States and Post-Conflict Societites: Core Concepts and Cross-Cutting Themes'. Public Administration and Development, Vol. 5, pp. 3-4

Brown, Frederick Z. and David G. Timberman (1998) 'Introduction: Peace, Development, and Democracy in Cambodia - Shattered Hopes'. In Frederick Z. Brown and David G. Timberman (eds), Cambodia and the International Community: The Quest for Peace, Development, and Democracy. New York: The Asia Society.

Burke-White, William (2005) 'Preferences Matter: Conversations with the Cambodian people on the prosecution of the Khmer Rouge leadership'. In Jaya Ramji and Beth Van Schaack (eds), Bringing the Khmer Rouge to Justice: Prosecuting Mass Violence before the Cambodian Courts. London: Edwin Mellen Press.

Cambodian Human Rights Action Committee 'Minimum Standards for Fair Trials of Leaders of Democratic Kampuchea'. Press Release, undated.

- - 'Letter to Prime Minister Hun Sen and UNSG Kofi Annan on the Special Tribunal to hold the leaders of the Democratic Kampuchea regime accountable'. Press Release, undated.

- - (2000) 'Cambodian civil society members call for independent foreign prosecutor in Khmer Rouge tribunal'. Press Release, 13 January.

- - (2001) 'Statement on the meeting with the Special Representative of the Secretary General for Human Rights in Cambodia (in reference to the lack of transparency in the recent passage of the Khmer Rouge Tribunal Law'. Press Release, 17 February.

- - (2001) 'Concerns regarding the rule of law in Cambodia'. Press Release, 21 May.

- - (2002) 'Understanding and support for the United Nations decision to withdraw from the current process of establishing a tribunal for the Khmer Rouge, although deeply saddened and disappointed by the loss of hope for justice... and asking the UN to persist in its best efforts to provide for redress and justice in Cambodia'. Press Release, 21 February.

- - (2003) 'Minimum Standards for Fair Trials of Leaders of Democratic Kampuchea'. Press Release, March 13.

Chandler, David (1999) Brother Number One: A Political Biography of Pol Pot. Chiang Mai: Silkworm Books.

- - (2000) Voices from S-21: Terror and History in Pol Pot's Secret Prison. Chiang Mai: Silkworm Books.

Chhim, Sopheak and William Shaw (2005) 'Report: Police Viewed as Highly Dishonest'. The Cambodia Daily, 21 September, p. 13.

Doyle, Michael W. (2000) 'Peacebuilding in Cambodia: Legitimacy and Power'. In Peacebuilding as Politics: Cultivating Peace in Fragile Societies. London: Lynne Rienner Publishers, pp. 89-111.

Ea, Meng-Try (2003) 'Justice and Reconciliation: Case Study Cambodia'. Dissertation submitted in partial fulfilment of the University's requirements for the degree of Master of Arts, Centre for the Study of Forgiveness and Reconciliation, Coventry University, September. 
Ehrenreich Brooks, Rosa (2003) 'The New Imperialism: Violence Norms and the "Rule of Law"'. Michigan Law Review, 2275, 101.

Estrada-Hollenbeck, Mica (2001) 'The Attainment of Justice through Restoration, not Litigation: The Subjective Road to Reconciliation'. In Mohammed Abu-Nimer, Reconciliation, Justice and Coexistence: Theory and Practice. Lanham: Lexington Books.

Etcheson, Craig (2004) 'Reconciliation in Cambodia: Theory and Practice' (Study Guide). Phnom Penh: Craig Etcheson.

- - (2005) After the Killing Fields: Lessons from the Cambodian Genocide. Westport: Praeger.

Fawthrop, Tom and Helen Jarvis (2004) Getting Away with Genocide? Elusive Justice and the Khmer Rouge Tribunal. London: Pluto Press.

Gottesman, Evan (2003) Cambodia After the Khmer Rouge: Inside the Politics of National Building. New Haven: Yale University Press.

A Group of Cambodian Jurists (1990) 'People's Revolutionary Tribunal Held in Phnom Penh for the Trial of the Genocide Crime of the Pol Pot- Ieng Sary Clique: Documents August 1979'. Phnom Penh: Foreign Languages Publishing House.

Hammarberg, Thomas (2001) 'Efforts to establish a Tribunal against the Khmer Rouge leader: Discussions between the Cambodian Government and the UN'. Paper presented at a seminar organized by the Swedish Institute of International Affairs and the Swedish Committee for Vietnam, Laos and Cambodia on the proposed trial against Khmer Rouge leaders responsible for crimes against humanity, Stockholm, 29 May.

Harris, Ian (2005) 'Onslaught on Beings: A Theravada Buddhist Perspective on Accountability for Crimes Committed in the Democratic Kampuchea Period'. In Jaya Ramji and Beth Van Schaack (eds), Bringing the Khmer Rouge to Justice: Prosecuting Mass Violence before the Cambodian Courts. London: Edwin Mellen Press, pp. 59-96.

Heder, Steve (2002) 'Hun Sen and Genocide Trials in Cambodia: International Impacts, Impunity and Justice'. In J. Ledgerwood (ed.), Cambodia Emerges from the Past: Eight Essays. DeKalb: Southeast Asia Publications, Center for Southeast Asian Studies, Northern Illinois University, pp. 176-223.

- - 'Politics, Diplomacy, and Accountability in Cambodia: Severely Limiting Personal Jurisdiction in Prosecution of Perpetrators of Crimes Against Humanity', based on a paper presented at the conference on Historical Justice in International Perspective, forthcoming, Cambridge University Press.

Heder, Steven and Brian D. Tittemore (2004) Seven Candidates for Prosecution: Accountability for the Crimes of the Khmer Rouge. Phnom Penh: Documentation Center of Cambodia. (Originally published by the War Crimes Research Office, American University, and the Center for International Justice in 2001.)

Henke, Roger and Kristina Chhim (2006) 'Donors, “Do No Harm”, and the Issue of Justice in Cambodia’. NIASnytt (3), pp. 12-14.

Hinton, Alexander Laban (2005) Why Did They Kill? Cambodia in the Shadow of Genocide. Berkeley: University of California Press. 
Hughes, Caroline and Kim Sedara (2004) 'The Evolution of Democratic Process and Conflict Management in Cambodia: A Comparative Study of Three Cambodian Elections', Working Paper 30. Phnom Penh: Cambodian Development Resource Institute, April.

Human Rights Watch (1998) 'International Tribunal Must not be Politically Selective', ASA 23/15/98, 30 April. Available: http://hrw.org/english/docs/.

_- (2001) 'Cambodia: Judiciary on Trial', 20 June.

_- (2002a) 'Cambodia: Tribunal Must Meet International Standards', 12 February.

- - (2002b), 'Cambodia: Khmer Rouge Tribunal Must Meet International Standards', 19 December.

- - (2003a) ‘U.N.: ‘Khmer Rouge Tribunal Flawed', Press Release, 30 April.

- - (2003b) 'Serious Flaws: Why the U.N. General Assembly Should Require Changes to the Draft Khmer Rouge Tribunal Agreement'. Briefing paper, 30 April.

- - (2004) ‘Donors Must Demand Real Reform', 3 December.

Hun Sen (1998) 'Excerpts of Samdech Hun Sen's Speech to a Grand Peace Meeting'. Cambodia New Vision, No. 5, April. Available: www.cnv.org.kh/cnv html_pdf/cnv $\underline{5 . h t m}$

- - (1999) 'Address of Samdech Hun Sen, Prime Minister of the Royal Government of Cambodia'. New York: UNGA, 20 September.

- - (2000) Prime Minister of the Royal Government of Cambodia, 'Speech at the Third Asian-German Editors Forum', Hotel Le Royale, 31 January, unofficial translation.

Jendrzejczyk, Mike (2002) 'Cambodia's Friends Should Get Tough', The International Herald Tribune. 19 June.

- - (2002) 'Cambodians, too, Deserve Justice'. The International Herald Tribune, 27 December.

Kiernan, Benedict (1997) The Pol Pot Regime: Race, Power, and Genocide in Cambodia under the Khmer Rouge, 1975-79. Chiang Mai: Silkworm Books.

Lambourne, Wendy (2004) 'Post-Conflict Peacebuilding: Meeting Human Needs for Justice and Reconciliation'. Peace, Conflict and Development. 6 (Issue 4, April).

'The Law Establishing the Extraordinary Chambers in the Courts of Cambodia for the Prosecution of the Crimes Committed during the Period of Democratic Kampuchea', 2001, NS/RKM/0801/12, 10 August amended on 5 October 2004. Available: www/ Cambodia.gov.kh/krt/English.

'The Law Outlawing the Democratic Kampuchea Group', 1994. English translation based on the text published by the Phnom Penh Post, Vol. 3, No. 14, 15-28, passed by the National Assembly on July 5 and signed by Loy Sim Cheang on July 15.

Letter from the RGC Co-Prime Ministers Norodom Ranariddh and Hun Sen to UN Secretary General Kofi Annan, June 21, 1997.

LICADHO Cambodian League for the Promotion and Defense of Human Rights (2003) 'Torture in Police Custody in Cambodia'. Briefing Paper, Phnom Penh, April. 
Linton, Suzannah (2004) Reconciliation in Cambodia. Phnom Penh: Documentation Center of Cambodia, Documentation Series No. 5.

Maguire, Peter H. (2005) Facing Death in Cambodia. New York: Columbia University Press.

Malloch Brown (2004) Briefing at the UNSC meeting, Report of the Secretary-General on the Rule of Law and Transitional Justice in Conflict and Post-conflict Societies. UNSC, S/2004/616, 6 October.

McFadden, David (2005) 'Study finds Refugees in US still traumatized by Civil War'. The Cambodia Daily, 6 September.

McGrew, Laura (2000) 'Truth, Justice, Reconciliation and Peace in Cambodia: 20 years after the Khmer Rouge'. Available: www.advocacynet.org.

- - (2006) 'Transitional Justice Mechanisms'. In 'The Extraordinary Chambers'. Open Society Justice Initiative, Justice Initiatives: New York, Spring, pp. 139-150.

Minow, Martha (1998) Between Vengeance and Forgiveness: Facing History After Genocide and Mass Violence. Boston: Beacon Press.

Open Society Justice Initiative (2006) 'The Extraordinary Chambers'. Justice Initiatives: New York, Spring.

Peou, Sorpong (1997) 'The Foreign Policy of Weak States: Cambodia's Domestic Crises and Dependent Status in World Politics'. The Cambodian Journal of International Affairs, Vol. II, No. 1.

Pin, Sisovann and Lee Berthiaume (2005) 'Prince Ranariddh: Put poverty before KR trial'. The Cambodia Daily, 1 September.

Pin, Yathay (1987) Stay Alive, My Son. New York: Touchstone.

Ramji, Jaya (2000) ‘Reclaiming Cambodian History: The Case for a Truth Commission'. 24 Fletcher Forum of World Affairs 137.

- - (2005) 'A Collective Response to Mass Violence: Reparations and Healing in Cambodia'. In Jaya Ramji and Beth Van Schaack (eds), Bringing the Khmer Rouge to Justice: Prosecuting Mass Violence before the Cambodian Courts. London: Edwin Mellen Press, pp. 359-376.

Secretariat of the Royal Government Task Force (2004) Office of the Council of Ministers, Kingdom of Cambodia. 'An Introduction to the Khmer Rouge Trials', August. Royal Government of Cambodia Task Force on the EC. Available: www.cambodia.gov.kh/ $\mathrm{krt} /$.

Seng, Theary (2005) Daughter of the Killing Fields: A'Srei's Story. London: Fusion Press.

Short, Philip (2004) Pol Pot: History of a Nightmare. London: John Murray.

Sok, An (2002) 'Presentation by His Excellency Sok An, Senior Minister, Minister in Charge of the Office of the Council of Ministers, President of the Task Force for Cooperation with Foreign Legal Experts and Preparation of the Proceedings for the Trial of Senior Khmer Rouge Leaders to the Stockholm International Forum: Truth, Justice and Reconciliation', 23-24 April. 
Sok, Sam Oeun (2005) Cambodian Defenders Project. Presentation at Federation International Droits de L'homme Workshop, 1 March.

Szymusiak, Molyda (1999) The Stones Cry Out: A Cambodian Childhood: 1975-1980. Paris: Giroux.

Un Kheang (2004) 'Democratization Without Consolidation: The Case of Cambodia, 19932004'. Dissertation, Northern Illinois University, Department of Political Science.

Ung, Loung (2000) First They Killed my Father: A Daughter of Cambodia Remembers. New York: HarperCollins.

United Nations (1991) Agreement on a Comprehensive Political Settlement of the Cambodia Conflict. Paris: UN.

-_ (1999) 'Identical Letters dated 15 March 1999 from the Secretary-General to the President of the General Assembly and the President of the Security Council' (otherwise known as the 'Group of Experts Report'). UNSC and UNGA, A/53/850 and S/1999/231, 16 March.

- - (2004) 'Report of the Secretary General on the Khmer Rouge Tribunal'. United Nations General Assembly, A/59/432, 12 October.

United Nations Economic and Social Council, Commission on Human Rights (2004) 'Advisory Services and technical Cooperation in the Field of Human Rights, Situation of human rights in Cambodia, Report of the Special Representative of the SecretaryGeneral for Human Rights in Cambodia, Peter Leuprecht'. E/CN.4/2005/116, 20 December.

United Nations High Commissioner for Human Rights (1997) 'Situation of Human Rights in Cambodia'. Commission on Human Rights resolution 1997/49, April.

United States Agency for International Development and Casals \& Associates (2004), 'Cambodian Corruption Assessment'. IQC Contract No. DFD-1-00-03-00129-00, Task Order No. 801, May-June 2004, Submitted August 19.

United States Congress (1994) 'The Cambodia Genocide Justice Act'. 102rd Congress, 2nd session, House Resolution 2333.

United States Government (1990) Cambodia: A Country Profile, see http://countrystudies. us/Cambodia/86.htm.

Urs, Tara (2007) 'Imagining Locally-motivated Accountability for Mass Atrocities: Voices from Cambodia'. SUR - International Journal on Human Rights (7) 61-180.

World Bank (2004) 'Cambodia at the Crossroads: Strengthening Accountability to Reduce Poverty’. Report No. 30636-KH, 15 November.

\section{INTERVIEWS/PERSONAL COMMUNICATION}

CPP insider (2005) Phnom Penh, 10 June.

Human rights NGO staff (2005) Kampong Cham province, 22 September.

McKinlay, Trina (2005) Personal correspondence (Email), 22 July.

NGO staff (2005) Phnom Penh, 18 April. 


\section{The Never Ending Hunt for Political Legitimacy in a Post-Conflict Context}

\section{Cambodia: A 'Hybrid' Democracy?}

\section{Mona Lilja and Joakim Öjendal}

Cambodia's long-standing internal conflict was to be solved through the introduction of a democratic constitution and its associated institutions, norms and practices (UN 1991). This democratic order - in combination with integration into the global economy - was also the key strategy for achieving the reconstruction of this war-ravaged society. Despite massive criticism, conflict resolution and the introduction of a democratic system went surprisingly well (Doyle 1995). However, opinions vary as to the longterm achievement of reconstruction through democratization (Paris 2004; Ottaway 2003). Put differently, it was assumed that the implementation of 'liberal peace' (Richmond 2005) would yield reconstruction in due time but, as $\mathrm{O}$. Richmond notes, this hypothesis has never really been put to the test and whenever liberal peace has been implemented it has produced various results. In Cambodia, the endemic contestation of political authority was addressed using the force and logic of liberal peace, but did the imposed democratic institutions deliver political legitimacy? Did they even deliver democracy? Did this result in reconstruction? This volume illuminates aspects of these issues and thus helps us move beyond the black and white of political polemics. However, as one approaches the horizon it moves further away - patterns become more complex and contradictory and this means that new modes of interpretation are required. Below, we present a view of the nature of democratization in Cambodia, to what extent 
political legitimacy has been achieved and what it may eventually solve. We conclude by pointing out some key features that we believe are essential to future analysis of Cambodian 'democracy'.

\section{INTERPRETING ‘DEMOCRATIZATION'}

In the wake of the 'third wave of democratization' (Huntington 1991) an impressive body of literature emerged (e.g. Huntington 1991; Carothers 1999; Diamond et al. 1989; Diamond 1999; Hadenius 1992). Consolidation has been a key term in this research field; establishing electoral democracy is really the easy part while consolidating it is more problematic (Diamond 1999; cf. Öjendal and Antlöv 1998). The notion of democratic consolidation is reflected in the so-called 'Transition Paradigm', which Carothers (2002) argues we now need to 'let go' of. 'New democracies' are not democratic, nor are they part of a transition to democracy; they fall instead into the 'political grey zone ... between full-fledged democracy and outright dictatorship' (Carothers, 2002). In other words, given the condition of many democracies in the South, some researchers have begun questioning the notion of 'new democracies' and instead begun describing these countries using terms such as 'electoral democracy', 'competitive authoritarian' or 'hegemonic electoral authoritarian' (Diamond 2002).

Clearly, the real-world complexities of major social change - as with 'democratization' - have outpaced the somewhat simple metaphors of the 'third wave of democratization' and 'transition' type of literature. Societies are not moving from A to B in a linear way, nor are outcomes given and the 'wave' metaphor has limited explanatory power. There is already ample empirical evidence and a large number of cases that show the multifaceted nature of in-depth 'democratization'. The empirical case studies from Cambodia presented in this volume demonstrate this. We simply cannot explain the political processes of the last fifteen years using the 'transition' mindset. 'Democratic' elements are introduced but they may then be rejected, altered, blended, negotiated or even reversed. For instance, some of the authors of this book conclude that: (1) a popular and democratic commune reform has been carried out in Cambodia that is de facto used to strengthen national autocracy; (2) a tribunal exists that is ostensibly to bring the perpetrators of genocide to justice but which in fact legitimizes a semi-democratic regime that was once party to genocide (McGrew, this volume); (3) a judicial system has been established that enables a 
dirty mix of Politics and Law while a semblance of democratic credibility is desired, good governance reforms introduced at grassroots level; (4) a political discourse has been developed that rhetorically embraces the values of Buddhism but in fact displays anything but these values; (5) a gender-sensitive public sector reform has been introduced in a patriarchal culture; (6) a sophisticated electoral system has been implemented that in effect ensures particular political outcomes; (7) an intensive cooperation with donors has been undertaken while donors' demands are blatantly disregarded.

Moreover, if democratic and peaceful development was anticipated following four consecutive elections and the implementation of a 'local democratic system' including commune elections, then this has been a disappointment. For instance, Human Rights Watch's world report 2006 draws the conclusion that ' 2005 saw a sharp reversal in progress Cambodia had made in observing human rights and developing political pluralism since the signing of the 1991 Paris Peace Accords'. Some opposition politicians lost their immunity, were arrested or were threatened in other ways. According to the report, not only political activists but also journalists who spoke out about issues such as land rights, illegal logging or the controversial border treaty with Vietnam were arrested, attacked, threatened, imprisoned or prosecuted. Many fled the country and some still remain in self-imposed exile. How, then, should we account for and explain the meaning of 'democratization and not'? What is clear is that 'transition' theory is insufficient to explain what Cambodia has experienced in the last decade and a half. How should this then be understood?

One way of illuminating political change has been proposed by Iris Young, who draws on Homi Bhabha's concept of 'hybridity', when analysing the 'Iroquois influence' debate to re-read some elements of the history of colonial and republican America in order to enhance contemporary selfunderstanding (Young 2000: 238). Taking the post-colonial debate as a point of departure, she uses the concept of hybridity somewhat differently from authors such as Diamond, who applies the concept of 'hybrid regimes' to denote countries that combine democratic and authoritarian elements ( $c f$. Diamond 2002: 23). In Young's research the concept of hybridity is instead used to signify how different discourses of decision-making mix with and influence each other in creating new discourses of decision-making - which do not necessarily include authoritarian elements. Young states that world history is commonly described in terms of linear progression; 
colonized people are described as those subjected to western power and as adapting to universal (western) values of liberty, democracy, technology and economic development. She objects to this portrayal and argues for a hybrid approach that reverses this linearity: 'Events and institutions in any locale may appear as products of cultural interaction where the Europeans are as much influenced as influencing' (Young 2000: 239).

This approach to political change has not been employed either by the 'Transition Paradigm' or by its immediate successors. Indeed, the approaches may be seen to be epistemologically incompatible. However, concepts such as discourse and hybridity may add considerably to our understanding of the political processes of 'democracy' in Cambodia. As will be elaborated below, Cambodia is not only an example of the classic problems facing new democracies, such as high military budgets and political instability, but the country also faces a number of more daunting challenges. New patterns and new notions have emerged; the old system of rule has blended with democratic discourse and a 'new' pattern of rule has evolved from this ( $c f$. Pak et al. 2007). For instance, our empirical chapters demonstrate how the official systems are increasingly marked by neo-patrimonial features that operate within a formally democratic structure - their representatives utilize non-democratic practices and the results are non-democratic outcomes. The 'public' and the 'personal' interweave so that the state apparatus tends to be used to build personal patronage networks instead of delivering what is expected of a state-building process, by an accountable state. It would also seem that the new system of democracy is informed by a kinship-oriented system of rule that re-emphasises the random and personalized - though not primarily authoritarian and repressive - nature of governance. These ambiguities help explain why advocates of the new order in Cambodia may interpret Cambodia as a successful case of intervention, change and transformation, while critics may equally describe Cambodia as a black hole of corruption and despotic power abuse.

There seems to be a 'hybrid' system of governance emerging in the 'grey zone' that Carothers mentions. Processes similar to those Young describes, as noted above, are taking place. Historical practices and installed 'democracies' coalesce, thus engendering a new blend. What, then, are the various processes, factors and interests that contribute to the (re-)shaping of these 'hybrid' practices and institutions? And how should systems like these be understood? 
While hybridity is a key feature of the emerging system, political legitimacy remains the key to making the system sustainable and stable, in spite of its apparent contradictions and mismanagement. It is only when citizens hand over power to their political leaders that a violent and repressive system of rule can be avoided (Arendt 1986). However, within a hybrid political system, legitimacy itself seems to have a hybrid nature; the politicians within the new institutions of liberal democracy lean heavily on traditional discourses and institutions to underpin their authority. These connections need to be further researched since the hybrid nature of both the political system and the legitimacy it generates remains decisive for the 'success' of post-conflict reconstruction efforts. The democratic hybriditypolitical legitimacy coupling will therefore be further discussed below.

\section{CAMBODIA: HYBRIDIZATION IN PROCESS}

The UN-led intervention in 1992/3 included a number of institutional and practical alterations. A massive discourse on the benefits of liberal democratic values was promulgated through the UN information units as well as through various grassroots efforts. In promoting human rights and the idea of basic freedom, for instance, the UN used traditional Khmer cultural media, such as singers, puppets, comics and local artists, in addition to radio and television (Finlay 1995: 28, 63-64). An election campaign was launched, conducted primarily by UN Volunteers and Radio UNTAC. This proved to be successful and, as Finlay concludes: 'As a consequence Cambodians really believed that the vote was secret and that election could bring peace and/or offer them a genuine voice in choosing their government' (Finlay 1995: 86). Of course, the implementation of a liberal democratic system was also coloured by its association with the emergence of peace, prosperity and freedom. This way of presenting certain values to the Cambodian population exemplifies the way in which a democratic discourse may be introduced into a society in order to build the foundations of a functioning democratic system. A dominant discourse - about the rightness of democracy - legitimates democratic institutions and the political system. However, the 'democratic' system of governance installed in Cambodia differs considerably from the ideal of liberal democracy and the result is an atypical system.

As noted, Bhabha's notions of hybridity may be used as a point of departure for analyzing democratic transformations (Young 2000). His 
starting point is the interdependence between colonizer and colonized and he argues that new cultural 'truths' are created as the concepts the colonizer brings are interpreted by the colonized in the light of their own culture. ${ }^{1}$ To illustrate this, Bhabha describes how the gospels were translated into the many languages of India, and how some vegetarian Hindus interpreted the eating of Christ's flesh as a form of cannibalism and drinking his blood as vampirism. In this way, re-interpretation functions as a means of resisting the colonial discourse and of questioning its authority (Ashcroft, Griffiths and Tiffin 2003; Bhabha 1994; Childs and Williams, 1997: 135-136).

However, hybridity involves more than simply practices of reinterpretation. Overall, the concept of hybrid/ity/ization is used to describe a situation where new species, traditions, discourses and social structures evolve from the blending of original ones (Kirkegaard 2004: 26). For example, as stated above, research has shown that the discourses and practices of patron-client relations in Cambodia are interlaced with the democratic discourse (Lilja 2008; Pak et al. 2007) and that those who were regarded as leaders in the old system of rule continue to be decision-makers in the contemporary democratic system. In addition, the kinship-based social organization of Cambodian society has become mixed with the new liberal democracy, creating a hybrid system in which political participation is steered partly by family connections (Lilja 2008). This pattern becomes still clearer when gender is considered: 'In the Khmer political realm, a woman's authority is determined by her kin relationships with male power figures. Wives of male leaders are viewed as especially powerful ...' (Frieson 2001: 3).

There may be many other explanations for the influence of kinship on the political arena. For example, the recruitment by politicians of kin to the political arena may be in part a consequence of the lack of political programmes or ideological standpoints to steer choices of political party. Similarly, Cambodian gender stereotypes are occasionally used within the democratic discourse, sometimes in order to enhance women leaders' legitimacy (Lilja 2008). Because, as Peterson and Runyan state: 'Being female is not always a disadvantage: When symbols of unity, compromise, or conciliation are sought, women may have an advantage over men. That is, stereotypes of women can work to the benefit of female leaders in situations where crises or transitions require a caring, ameliorative figure' (Peterson and Runyan, 1993: 69). Whatever the reason, the outcome is a system in which power within the 'new liberal democracy' may sometimes be sought 
or distributed according to family links, thus yielding a hybrid system in which traditional discourses and practices are mixed with the newly implemented system. This hybridity to an extent determines the sources of political legitimacy.

Another example of the hybrid appearance of Cambodian democracy may be found in the discrepancy between discourse and practice. While 88 per cent of Cambodians agree that 'to have a democracy, there must be elections with more than one party competing' (Asian Foundation 2003), only 28 per cent identify parties' policies, views and ideology as motives for voting (Asian Foundation 2003). In other words, the idea that the existence of competing party ideologies is one of the cornerstones of liberal democracy has not taken root in Cambodian society. Nevertheless, there is a demand for a plurality of parties and this suggests that aspects of the democratic discourse introduced by the UN and upheld by the donor community and others are widely held and accepted in Cambodia. However, this discourse plays a minimal role at the moment of casting a vote. Indeed, field research shows that in the 1993 and 1998 elections Khmers voted to 'ensure a leader would reward them for their loyalty in much the same way as they would under the traditional khsae networks' (khsae being the string of mutual gift exchanges from elites in return for loyalty from villagers; Roberts 2001: 204). Thus the democratic discourse as it was implemented in 1993 still dominates, although it is not reflected in democratic practices such as those related to party programmes, institutional performance and political accountability. This begs a number of interesting questions. When, for instance, do democratic discourses give rise to corresponding practices? What does the discrepancy between discourse and practice reveal about the democratic system and its hybrid nature? Most significantly here, what does it say about the viability of post-conflict political reconstruction in Cambodia?

\section{HYBRID DEMOCRACY AND POLITICAL LEGITIMACY IN CAMBODIA}

Themessages from the chaptersin thisvolumeare complexand contradictory. Most would agree that there is overall a relatively successful process of postconflict reconstruction - though not necessarily democratization - taking place in Cambodia. By comparison with other countries and when viewed from above, from the outside, and with a limited knowledge of the inner workings of society, progress would seem sensational; there is stability, 
democratization, reforms, growth and even some poverty alleviation. However, none of the contributors to this volume would be comfortable glossing over the gross abuses, severe shortcomings and blatant exploitation that mark Cambodian society in the midst of this 'progress'. Yet, amid these evils is another story to be told of local heroes, development potentials and genuine attempts to make gradual but important improvements. No conclusion may be drawn without either reservation or addendum. General condemnation is not appropriate - change is occurring at breakneck speed, but the direction of change is elusive. To explore Cambodia's democratic ambiguity, we have chosen to discuss how and to what extent the current regime has managed to establish political legitimacy.

Enjoying a degree of legitimacy used to be considered a basic condition for obtaining the power to rule. As Muthiah Alagappa argues, 'the "Language of legitimacy" often defines what is and what is not legitimate political activity' (Alagappa 1995: 3). Legitimacy denotes to what degree the population accepts and supports the regime and may be pursued by leaders in a number of ways. Hughes (this volume) states that legitimacy in Cambodia has often been interpreted as a purely procedural affair. However, she argues, the Cambodian elites have a tendency to 'pick and mix' from a wide range of legitimizing discourses. This reasoning is interesting in light of the concept of hybrid democracy. How is legitimacy sought within a 'hybrid democracy'? Is it sought within the new 'liberal democracy' or through reference to old discourses of power, status and decision-making, or via both?

The introduction of elections, which enable legitimacy to be in some way measured, is the very core of the political 'revolution' in Cambodia. Chandler has argued that historically rulers in Cambodia never needed to justify their rule (cf. Chandler 1983); during the 1970s and 1980s the level of violence was such that 'legitimacy' '[grew] out of the barrel of a gun'. Since 1993, however, it can be argued that the popular vote has provided a new instrument for measuring the degree of legitimacy and for publicly displaying it. However, legitimacy encompasses far more than the production of governments based on election results; it draws upon a broader set of processes and activities, operates on several levels and is dynamic over time.

Marston, for instance (this volume), provides examples of the connection between political rallies and Buddhism. When politicians donate to the wats this is marked by a ceremony that is a collaborative venture involving 
both the wat and the political leader. These rituals reward political leaders with some legitimacy. Marston relates that he has often witnessed monks attending political rallies 'although it was not so clear whether their presence represented an endorsement so much as an acknowledgement of the appropriateness of having monks as a ceremonial presence at any public event'. This is one example of how local institutions and beliefs provide political legitimacy to leaders within the 'new' democratic system, creating a hybrid of the 'old' and the 'new'. The legitimizing discourses within the political sphere of 'liberal democracy' also rely upon traditional notions and norms of decision-making.

Similarly, Lilja (2008) notes that due to the (re)emergence of 'traditional' patron-client relations after the Khmer Rouge era, some female survivors have managed to build up democratic power bases. In one sense, therefore, traditional hierarchies have helped to determine who has offices in the newly implemented 'democracy'. The distribution of legitimacy within new democracies takes place along traditional lines, thus providing another example of hybridization. Or as Hughes (this volume) explains, the Cambodian leadership uses a variety of different discourses to gain legitimacy, and these are 'drawn from ideologically driven interpretations of history, popular (and populist) notions of a supposed Khmer ethnic tradition, ideas of charismatic authority, and locally inflected interpretations of global discourses about international law, environmentalism, and the nature of modernity'.

The duality of agendas, political culture(s), and political systems is perhaps nowhere more evident than in the ongoing public sector reform. Decentralization and the insertion of local democracy runs counter to the idea that the dominant party is primarily interested of remaining in power. Not only have soft governance and a genuinely successful democratic reform been carried out, but remaining public sector reform now hinges on the Commune Council, which is arguably the most democratic forum in the entire system. Öjendal and Sedara struggle to make sense of this duality and they arrive at the conclusion that this is after all a deliberate use of a western democratic discourse to consolidate traditional power centres.

However, there is ambiguity in this hybridity. The mixing of different discourses may enable leaders to justify their positions of power within the 'new democracy' but discourses may also conflict and give rise to loss of political legitimacy. One example of the notions of the 'traditional' and the 'new' is given by Marston (this volume), who points out that when the 
UN in 1993 declared that monks and prisoners would be allowed to vote, this decision paid little attention to the Cambodian context and prevalent religious discourse. Since then there has been debate about whether monks should vote and some prominent monastic leaders have even discouraged monks from doing so. Some commune chiefs have supported this and prevented monks from voting and some wats have threatened to expel monks if they vote (Falby 2003). Newly implemented 'liberal democracy' is then questioned from the platform of local 'traditional' notions of decisionmaking.

Frustration is also felt when people experience a gap between the notion of a 'proper' democratic system and the actual system of rule. Ear, for example (this volume), remarks that 'Political legitimacy has also meant anointing RGC policies with a donor stamp of approval even while RGC action and development outcomes themselves deviate far from donor and civil society expectations.' Likewise, Un claims that patronage politics and the elite's lack of commitment to democracy enable hybridity to emerge, and he notes that this is connected to the corruption and politicization of the judiciary and its inability to maintain the rule of law. Consequently, in Un's chapter Cambodia is measured up to established democratic standards in order to see how the country falls short.

Another argument that is sometimes heard in Cambodia is that corruption and patron-client relations are not in themselves evil but that they acquire negative value when they are compared to the western norm of liberal democracy. Therefore, although we should not belittle the problems of corruption, impunity, autocracy and political manipulation, it is nevertheless important to remember that the emerging hybrid system is valued differently by different observers according to the expectations they had from the outset - conclusions depend upon perspective. If the idea of liberal democracy is taken as the point of departure, the hybrid system will be called into question. Hasselskog (this volume), however, takes a slightly different stance and questions the very 'makeability' of a society. She proposes that it is not possible to impose a discourse without taking into consideration how its meaning is transformed in the local context and that this transformation will not be entirely predictable. Like Bhabha and Young, Hasselskog notes how locals 'fight back' by assigning values and meanings according to their own rationale and in keeping with local power structures. This makes for an unpredictable system of rule and it complicates the issue of political legitimacy. 


\section{SIX CONCLUSIONS}

Our original question at the start of this book concerned to what extent post-conflict reconstruction has taken place through democratization. Is there any real legitimacy that substantiates 'democratization'? Post-conflict reconstruction in Cambodia has been relatively successful; the general situation in the country is better and more politically stable than it was in 1991, not to mention 1979. The constitution of 1993 is not under threat and no violent outbreaks can be predicted within the foreseeable future. The political regime ( $c f$. definition in Chapter 1), can be argued to enjoy a high degree of legitimacy, and this supports a positive view of post-conflict reconstruction. However, the middle ground, democratization, which is presumed to deliver post-conflict reconstruction, remains elusive. The ambiguities of its implementation - its blatant failures yet rigid adherence to its institutional cornerstones - prompt us to look beyond standard politics in order to describe its complexity. Six features may help us further to explore the possible interpretations of 'liberal democracy' as it is implemented in the Cambodian context.

(1) The time and space of democratic discourse are important. In what forums is the democratic discourse perpetuated, how and by whom? Connecting the concept of discourse to the topic of democracy provides a sense of the construction of 'meanings' of democracy, how these 'meanings' are produced at various sites and how they are disseminated via various processes or practices. A study of political change should include an analysis of the 'where' and 'how' of democratic discourse. Where and when is this discourse reiterated, maintained and contested? Who are the actors involved? Are the discourses of liberal democracy diminishing over time? Or are they reinterpreted? In post-conflict countries in particular the immediate effects of the imposition of democracy are peculiar and dynamic, though normality (whatever that is) may ultimately be resumed.

(2) The notion of hybridity may be used as a springboard for analyzing democratic transformation. By reinterpreting the discourse of the West, the 'rest' may resist, shift power and question discursive authority. Can this pattern be discerned in the Cambodian case? Is liberal democracy reinterpreted in ways that give rise to new understandings of democracy and how it should be implemented? Is a 'hybrid' of liberal democracy and historical neo-patrimonialism emerging? What, in that case, are the hallmarks of such a system? May the reinterpretations of liberal democracy 
be related to the 'classical problems' associated with inserted democracies, such as impunity and corruption? Should 'reinterpreted' democracy be considered democracy at all? How should interpretations be considered when promoting democracy in the South? For instance, research has shown that Cambodian patron-client relations are interwoven with the democratic discourse and that those who were leaders in the old system of rule continue to be decision-makers today. Where and how are discourses mixed in ways that yield new discourses and new practices?

(3) Discourse shapes and influences both thought and action. In the Cambodian case, the democratic discourse introduced by the UN and later supported by the international community is still strong, although it is not reflected in democratic practices in party strategies or the judicial system. This begs a number of questions, since clearly the implementation of democratic discourse does not guarantee that it will be translated into corresponding practice. How, then, may democratic discourse provoke corresponding practice? What does the gap between discourse and practice reveal about the democratic system? How should policy be formulated in order to take into consideration the fact that discourse does not necessarily deliver democratic practice?

(4) We must consider which elements of liberal democracy are compatible with local 'culture'. Democratic institutions, ideas and practices are and should be valued according to the specific cultural resources, needs and circumstances of each place (Parekh 1993). It is therefore appropriate to consider how the local context influences the way in which some aspects of democratization become adopted and valued while others are muted or ignored. This relates to how different discourses may conflict and give rise to loss of political legitimacy, as exemplified in this book. How is this taking place in contemporary Cambodia and what does this mean for the democratic system of the country? In what way might the concept of 'compatibility' assist the analysis we are promoting? Although we consider this a key point, it should not be understood as an argument in favour of 'tradition' or as an excuse for authoritarianism. We do not contend that political cultures are unchangeable.

(5) 'Power' should be a core concept in analyzing the implementation of 'democracy'. Democratic practices distribute power just as gendered hierarchies, for instance, determine who gains political power. Local power structures that devalue the poor, women, the rural population and ethnic minorities impact upon public decision-making. Liberal democracy, 
however, refuses to acknowledge differences of identity or wealth since this would undermine the principle of equality. How, then, do local powerrelations interact with imposed 'democracy'? Conversely, what kind of democracy do existing power structures allow?

(6) We need further to analyse the processes of reconstruction/ reconciliation in regard to 'liberal democracy'. In the aftermath of violence and the destruction of local institutions and practices, people seek to reconstruct some sense of normality. This 'normality' is often a reconstruction of a pre-war, pre-democratic society. How does the (re)construction of 'old' discourses, practices and institutions impact upon the implementation of democracy? And how does this relate to impunity, corruption and other problems of new democracies? Many war-torn societies are characterized by competing/conflicting identities and attempts to reconcile these differences. How do such conflicts and reconciliation efforts affect democratization? How can democracy handle these competing identities?

We believe that these six categories of analysis should be considered when describing the processes of political change in Cambodia. Cambodian society is undergoing change but it is not undergoing a one-dimensional transition. Change is complex - in terms of process and in terms of outcome - and the struggle to understand it and describe it will continue. This book is the latest but not the last attempt to find ways to reflect this complexity.

\section{NOTE}

1 We do not argue that UNTAC was 'colonial', although the psychology of the processes at stake in the implementation of a new political system is at times strikingly similar to this of colonialism ( $c f$. Hasselskog, this volume).

\section{REFERENCES:}

Alagappa, Muthiah (1995) Political legitimacy in Southeast Asia: the quest for moral authority. Stanford: Stanford University Press.

Arendt, Hannah (1986) ‘Communicative Power'. In Steven Lukes (ed.), Power. Oxford: Basil Blackwell, pp. 59-75.

Ashcroft, Bill; Gareth Griffiths and Helen Tiffin (2003) Post-Colonial Studies: The Key Concepts. London: Routledge. 
Asia Foundation (2003) Democracy in Cambodia - 2003: A Survey of the Cambodian Electorate. Phnom Penh.

Bastian, Sunil and Robin Luckham (eds) (2006) Can Democracy be Designed? The Politics of Institutional Choice in Conflict-Torn Societies. London: Zed Books.

Bhabha, Homi K. (1994) The Location of Culture. London: Routledge.

Bo Chum Sin (1997) Women and Leadership. Phnom Penh.

Call, Charles T. and Susan Cook (2003) 'On Democracy and Peacebuilding'. In Governance After War: Rethinking Democratization and Peacebuilding. Special issue (Vol. 9:2, Spring) of Global Governance, Charles Call and Susan Cook (eds).

Carothers, Thomas (1999) Aiding Democracy Abroad: The Learning Curve. Washington DC: The Brookings Institution.

- (2002) 'The End of the Transition Paradigm'. Journal of Democracy, Vol. 13, January, pp. 5-21.

Chandler, David (1983) A History of Cambodia. Boulder Colorado: Westview Press

Chandler, P. David (1993) The History of Cambodia. Oxford: Westview Press, Inc.

Childs, Peter and Patrick Williams (1997) An Introduction to Post-Colonial Theory. Hemel Hempstead: Prentice Hall.

Diamond, Larry (1999) Democracy in Developing Countries. Boulder, Colorado: Lynne Rienner.

- - (2002) 'Elections Without Democracy: Thinking about Hybrid Regimes'. Journal of Democracy, Vol. 13, pp. 21-35.

Ebihara, May (1968) 'Svay, a Village in Cambodia'. PhD dissertation, Colombia University, New York.

Falby, Patrick (2003) 'To Vote or Not to Vote: Buddhism's Monks Debate Their Rights.' The Phnom Penh Post, June 19.

Finlay, Trevor (1995) Cambodia: The Legacy and Lesson of UNTAC. New York: SIPRI Research Report, No. 9.

Frieson, Kate (2001) In the Shadow: Women, Power and Politics in Cambodia. Occasional Paper No. 26. Victoria: Centre for Asian-Pacific Initiatives.

Hadenius, Alex (1992) Democracy and Development. Cambridge: Cambridge University Press.

Hall, Stuart (1992) 'The West and the Rest: Discourses and Power'. In Stuart Hall and Bram Gieben (eds), Formation of Modernity. Cambridge: Polity Press in association with the Open University.

- - (1997) 'The Spectacle of the "Other"'. In Stuart Hall (ed.), Representation: Cultural Representation and Signifying Practices. London: Sage.

Heder, Steven and Judy Ledgerwood (1996) Propaganda, Politics, and Violence in Cambodia: Democratic Transition under United Nations Peace-keeping. Armonk and New York: M. E. Sharpe. 
Huntington, Samuel P. (1991) The Third Wave: Democratizaton in the Late Twentieth Century. Norman: University of Oklahoma Press.

Hydén, Göran (1998) Demokratisering i tredje världen [The Democratization of the Third World]. Lund: Studentlitteratur.

Kirkegaard, Ane (2004) A Matter of Difference? Family Planning and Gendered Discourses on Sexuality and Reproductive Decision-making among Black and White Zimbabweans. Göteborg: Department of Peace and Development Research, Göteborg University.

Ledgerwood, Judy (1996) 'Politics and Gender: Negotiating Conceptions of the Ideal Women in Present Day Cambodia'. Asia Pacific Viewpoint, Vol. 37, No. 2, August, pp. 139-152.

- - (1998) 'Rural Development in Cambodia: The View from the Village'. In Frederick Z. Brown and David G. Timberman (eds), Cambodia and the International Community - the Quest for Peace, Development and Democracy. Singapore: Asian Society and Institute of Southeast Asian Studies.

Lilja, Mona (2008) Power, Resistance and Women Politicians in Cambodia: Discourses of Emancipation. Copenhagen: NIAS Press.

McGrew, Laura, Kate Frieson and Chan Sambath (2004) Good Governance from the Ground Up: Women's Role in Post-Conflict Cambodia. Phnom Penh: Women Waging Peace.

O’Donnell, Guillermo and Philippe C. Schmitter (1986) Transitions from Authoritarian Rule: Tentative Conclusions about Uncertain Democracies. Baltimore: Johns Hopkins University Press.

Öjendal, Joakim \& Hans Antlöv (1998) 'Asian Values and its Political Consequences - is Cambodia the First Domino?' Pacific Review, Vol. 11, No 4, 1998

Ottaway, Marina (2002) 'Rebuilding State Institutions in Collapse States'. Development and Change, Vol. 33, No. 5, pp. 1001-1023.

Ovesen, Jan, Ing-Britt Trankell and Joakim Öjendal (1996) When Every Household is an Island. Stockholm: Uppsala Research Reports in Cultural Anthropology, 0348-9507; 15.

Parekh, Bhikhu (1993) 'The Cultural Particularity of Liberal Democracy'. In David Held (ed.), Prospects for Democracy: North, South, East, West. Cambridge: Polity Press, pp. 156-175.

Peterson, V. Spike and Anne Sisson Runyan (1993) Global Gender Issues. San Francisco: Westview Press.

Pettit, Philip (2003) 'Deliberative Democracy, the Discursive Dilemma and Republican Theory'. In Fishkin and Laslett (eds), Debating Deliberative Democracy. Oxford: Blackwell, pp. 138-162.

Richmond, Oliver (2005) The Transformation of Peace. London: Palgrave.

Roberts, David W. (2001) Political Transition in Cambodia 1991-99: Power, Elitism and Democracy. Richmond: Curzon Press.

- - (2003) 'From "Communism" to "Democracy" in Cambodia: a Decade of Trans- 
formation and Beyond'. Communist and Post-Communist Studies 36. Available: www. sciencedirect.com. Pergamon, pp. 245-258.

Schmitter, Philippe C. and Terry Lynn Karl (1991) 'What Democracy Is ... and Is Not'. Journal of Democracy 2 (Summer), pp. 75-88.

Young, Iris (2000) 'Hybrid Democracy: Iroquois Federalism and the Postcolonial Project'. In Will Sanders (ed.) Political Theory and the Rights of Indigenous Peoples. Cambridge: Cambridge University Press.

Kimchoeun et al. (2007) Accountability and Neo-Patrimonialism in Cambodia: A Critical Literature Review, Working Paper 34. Phnom Penh: CDRI 


\section{Index}

abuse of power $81,92,207,211-12,300$

accountability 103, 120-1, 152, 163-4, 167, 170, 190, 193-4, 200, 203, 206-7, 209-10, 213, 217, 220(n29-30, n3), 271-2, 279, 303

horizontal 71-3, 93-4; vertical 71-2

ADHOC xiv, 89, 92, $97,269,291$

aid $49,111,138$

bilateral 156, 174; 'cannot substitute for democratic process' 175; contribution to Cambodian budget 155; frozen (1997) 166; fungibility 156, 160-1, 166, 178(n23); 'mainly used for tax reduction' 180(n44); pledges 159-61, 175; political economy 15188; transformation into political legitimacy 160-3

aid dependence 153-4, 155-7, 159-65, 175, 178(n19-20)

aid donors $8,13,22,31,151-5,161,166,168-9$, 171-2, 173, 176(n8), 181(n48), 192, 259, 269, 278-80, 287, 299, 306;

diversification 170-1; 'make corruption worse' 158; 'national interest takes precedent' 156, 178(n24); RGC's view 163-5; votes of confidence (for Cambodia) 159-60, $174-5$

Alagappa, M. 304, 309

Amnesty International 90, 254, 257, 265, 291

Antlöv, H. ii, 298, 311

Aristide, J-B. 178(n24), 182

army/armed forces 38, 56-7, 59-61, 64, 123, 169, 172,259

ASEAN 46, 162-3, 261

Asian Development Bank xiv, 78, 97, 152, 164, 180(n46)

Association of Nuns and Laywomen of Cambodia (ANLWC, 1995-) 229-30, 233

Australia 245, 254, 260, 268-9

Battambang 41, 114, 117, 118, 243-5

Becker, E. 283, 291

Beyond Democracy in Cambodia

approach 3-9; connotations 2; prime concerns 8-9, 21; observation and analysis 'key tasks' 23; theoretical underpinnings 10-20; structure 20-4

Bhabha, H. K. 299, 301-2, 306, 310 'big people' 86, 210-11

Boyle, D. 254, 292

Brinkerhoff, D. W. 18-19, 26, 70, 265

Buddhism 22-3, 43, 44, 224-49, 283, 299, 304-5

Buddhist socialism 36, 38, 41-2

budget 172, 178(n23), 179(n37), 269, 279

aid dependence 155 ; credibility 169 ; deficits 151, 154, 176(n1), 177(n16); expenditure 155, 166, 181(n49); official 169, 180(n47); revenue $155,167-8,173,180(\mathrm{n} 46)$

budgetary crisis (1997-2003) 153, 165, 166-8; lessons 170-3, 174

Buth Savong 238-9, 242, 243-7, 248

Call, C. T. 15, 16, 24(n5), 26

Cambodia Demographic and Health Surveys (2000, 2005), 177(n11), 179(n29

Cambodian Human Rights Action Committee 257, 265, 292

Cambodian People's Party (CPP) 7-8, 32-4, 48-66, 67(n7), 174, 246, 285, 290(n24); ability successfully to stage elections 51,52 , 54; commune council elections (2002) 126, 128-9, 130(n9); commune councils 123; consolidation of power 126 ; decentralization reform 110-11, 130(n9); ECCC 250, 253, 257, 261-2, 264, 267, 275; image of competence 49-51, 53-4, 56-8, 60-1, 63-5; judicial affairs 86, 88, 93-5; 'Vietnamese' origins 50,54 ; weakness of opposition parties 49; women 137, 139

CARERE (Cambodia Resettlement and Reintegration, 1992-5) 130(n6), 132, 217-18(n4)

CARERE2 (Cambodia Area Rehabilitation and Regeneration, 1996-2000) 191-3, 2001, 204, 206, 213, 217(n2, n6), 218(n4), 219(n19)

Carothers, T. 7, 26, 298, 311

Centre for Social Development 164, 276, 283

Chandler, D. 35-6, 38, 45, 67, 283, 292, 304, 310

Chhim Sopheak 276, 292

Chilbo Industrial Co. Ltd. 80, 96(n11), 98

China 25(n16), 46, 162, 171-2, 175, 185, 188, 253, 260, 266-9, 284, 288(n2), 289(n19), 290(n21) 
civil servants/civil service 35, 91-2, 128, 155-6, $164-5,172,175,176(\mathrm{n} 8), 178(\mathrm{n} 22, \mathrm{n} 25)$

civil society $72,101,103,106-7,174,224-5,250$, 254, 260, 274, 278, 280-1, 284, 286-7, 306; Buddhism and 227-36; motives and interests in ECCC 264-6

civil war/s 2, 9, 15, 56, 105, 118, 123, 152, 176(n5)

Coalition Government of Democratic Kampuchea (CGDK) 46, 262-3, 267, 278, 290(n25), 285

Cold War 2, 3, 36, 47, 266-7; Cambodian neutralism $37-8,40$

colonialism 36, 74, 113, 302, 309(n1)

Committee for Free Elections in Cambodia (COMFREL) 54, 67(n3), 67

Commune Administration law (2001) 108, 111 commune chiefs 113-14, 116, 118-20, 130(n9, n15), 192, 195-8, 202, 207-8, 211-13, 237, 306

commune councillors 115, 120-1, 126, 130(n15), 220(n 30, n32-3);

loyalties 121; roles and responsibilities

220(n29); selection (involuntary) as

candidates 208-9, 220(n31)

commune councils 108, 123-9, 130(n7, n9), 218(n16), 219(n23-4, n26), 305

cannot deliver 'development' 119; colonial era 112; popular perception 115, 116-19; power 119, 130(n15); problems 120-1; role 119-22

Commune Development Committee (CDC) 193, 201-2, 205, 218(n7)

Commune Development Plan (CDP) 193, 219(n21)

communes 49, 210-13;

composition 192; decrees $(1908,1925) 112$;

elections 53-5, 57-8, 108, 117, 123, 125, 127,

128-9, 131(n17), 192, 217(n6); 218(n8), 299;

historical role 112-14

Communist Party of Kampuchea 34, 38-40, 42

conflict resolution 107, 195-7, 199, 207

Constitution (1993) 21, 70-1, 75, 92-3, 96, 110 , $114,162,297,307$

Consultative Group (CG) meetings 159-61, 165, 171, 179(n35-6)

corruption $8,25(\mathrm{n} 10), 31,33,35,40,58,60,64$, 66-7(n1), 102, 179(n36), 269, 277, 27980, 300, 308, 309;

failure to pass a law against $\sim 158,164-5$, 174, 180(n41-2); judicial 75, 80, 81-4, 87, 89-91, 94-6; local level 118, 119, 121; political economy of aid 152-3, 154-9, 161, 164-5, 167, 174, 180(n42)

Corruption Perception Index 158, 179(n33-4)

Council for Legal and Judicial Reform 76, 92, 277, 288(n2)
Council of Ministers 162, 165, 174, 178(n23)

court cases: failure to process 89-90; political, 87; political and civil 86

court clerks 78, 80, 82, 89, 93, 96(n4, n9); appointment and transfer 83-4

court officials 76, 77, 80, 85, 87, 88, 96(n2), 275, 277; living conditions 81

court warrants: failure to execute $80-1,85-6$ courts 74, 79, 94, 197, 275-6, 287

'fish market' analogy 89 ; lack of resources 75-6; profit-maximizing environment

89-90, 97(n15); provincial 82, 210

culture 25(n11), 46-7, 82, 107, 117-18, 130(n5), 138, 232, 250, 282, 283, 300, 302

debt 172-3, 181(n50, n53)

decentralization 22

evolution 108-12; literature 103-4,

106-7, 115, 116; qualitative and quantitative material 115; theoretical underpinnings of local approach 104-7

decentralization reform 101-35, 161, 191, 217(n6), 218(n14), 305

consequences for overall democratization

126-7; content and process 108-9, 130(n7);

fieldwork 130(n11); means to political reconstruction 127-8; 'outpaces national reform' 123; panacea versus cul-de-sac 128-9; political consequences 124-8; rationale 109-12; 'two key changes' 120 defence 155, 167-9, 178(n23), 273, 300

democracy 171, 236

'big-bang insertion' (1993) 102, 106, 109, 129; consolidation 14-15, 298; general and particular applications 14-17; 'inserted' 247, 308 ; motives for voting 303; multi-party 162 ; national level (boosted by decentralization) 128-9; 'procedural' 15, 32, 33; 'proper' versus 'actual' 306 ; quality 62 ; sustainability 101-2

Democrat Party 34-41, 53

Democratic Kampuchea (DK, 1975-9) 43-5, 46, 47, 49, 250;

retained Cambodia's seat at UN throughout 1980s 254; terminated the judiciary, 74; see also Khmer Rouge

Democratic Party of Kampuchea (DPK) zones 157-8, 184, 263, 290(n24)

democratization 1-24, 26(n18), 102, 224, 297, 298-301, 303

Cambodia far from 'ready' 5; conclusions 307-9; 'conclusions depend upon perspective' 306; consequences of decentralization reform 126-7; demand for 3-4; enforced 21; general and particular 
applications 14-17; judicial system and 70-100; literature 298; local 124-6; longterm processes 4,5

deputy village chiefs 195, 199, 205, 207-8, 211, 217(n5), 220(n28)

development 59-60, 119, 121-3, 145-7, 153, 166, 174, 191, 206, 213, 215;

political economy of aid, 154-9; villagers' perceptions 200-5

development agencies/actors 203-5, 216-17, 219(n23)

development projects/programmes 59, 60, 166

Dhammayietra movement 228-31, 233, 240

Diamond, L. 16, 27, 299, 310

discourse 137, 139-41, 144-5, 146-8, 300-2, 305

democratic 308; democratic (time and space)

307; hegemonic 13; political 67(n6); power-

loaded 146; versus practice 303; 'shapes

thought and action' 308

distance (ruler vs ruled) 115, 116, 122, 199, 200

districts 111, 121, 192, 210, 213

Dith Munthy 76-7, 252, 288(n2)

Documentation Centre of Cambodia (DC-Cam) 257, 266, 272-3, 283, 289(n18)

'dominant power politics' (Carothers) 7

Dutch disease 153-4, 155, 156, 159, 174, 177(n10), 181(n52)

Ear, S. xi, 22, 176(n7), 177(n9), 181(n49), 182-3, 306

Ebihara, M. 39, 43, 67(n10), 67

economy $18,42,107,110,154-5,268-9$

education $118,125,139,143,155,169,171$, 178(n23), 181(n49), 191, 206-7

election (1993) 9, 33-4, 48-51, 75, 108, 110, 130(n9), 152, 163, 192, 237, 251, 303-4

election (1998) 34, 54-5, 57, 63, 66, 162, 166, 238,303

election (2003) 33-4, 52, 54-5, 59-61,66, 67(n7), $162-3,237$

election (2008) 33-4, 263

elections 3-8, 19, 21, 299

credibility $31,33,67(\mathrm{n} 3)$; democratic

legitimacy (1946-2008) 34-42; local and

international responses 60-3; 'may not

deliver legitimacy' 18 ; reconstruction of

'legitimate political authority' 31-69; turn-

out rates 40-1; women's participation 139

elites $8,19,32,35-6,38-40,70-1,81,95,106-7$,

114, 119, 126, 206, 219(n26), 260, 277, $288,303-4$

empiricism ix, 5, 8-9, 13, 23, 24(n5), 94, 104, 107, 111-12, 114-15, 125-6, 194, 298, 300

Escobar, A. 145, 147

Etcheson, C., 254, 293 ethnicity $13,32,48,107,308$

executive branch 80, 84-9

Extraordinary Chambers in Courts of Cambodia (ECCC, 2006-) 250-96

balancing acts 270, 271, 290(n24); budget 257, 288(n6); corruption 260; defence support 258; funding, 258-9; history and structure 251; international standards 2867; issues and challenges 270-7 , 284-5, 287; legacy and legal reform 277-8; legitimacy 276, 277, 287; 253, 257, 265, 267, 278; motives and interests of key actors 260-9; personnel 257, 288(n8); politics 252-6; purposes 256; RGC-UN agreement to establish (2003) 256-7; structure 256-60; supermajority verdicts $257-8,289$ (n9); surveys 265 , 289(n16); victims 258, 286; witness protection 258

failed states 152, 173, 176(n5), 183, 186

Food for Work 123, 204

France/French 36, 74, 92, 112, 176(n3), 233, 253-4, 258, 260, 262, 266, 268-9

Frieson, K. 39, 67(n4), 68

FUNCINPEC xiv, 33, 50, 53, 55-7, 65, 88, 94, $163,253,263,285$

commune council elections (2002) 130(n9); disarming 56; flight of leadership (1997) 56; women 137,139

Galtung, J. 13, 27

Ganna kammathikā buddhamandal vipassanā thura [Committee for Vipassanā Meditation Centre] 239-41, 248

GDP 22, 155, 157-9, 167-8, 172-4, 176(n1), 178(n28), 181(n54)

genocide 1, 14, 24(n1), 46, 57, 152, 176(n5), 252, 261, 263, 270-1, 273, 281-2, 291(n33), 298

Global Witness (GW) 169-70, 183-4

globalization 12, 17-18, 25(n14), 136-50, 282;

governance 11, 22, 105, 123-4, 126, 129(n4), 144, 152-3, 156-7, 159, 162-3, 166-8, 172-4, 176(n6), 178(n26), 181(n53), 274-5, 299-300, 305

governance intervention 189-223;

'can be done by local agencies' 217(n1);

external design 190, 203, 214, 217;

impact on local power structures 205-7;

implementation dynamics 190-1

government officials $74,84-5,88-9$

Hammarberg, T. 254, 268, 293

Hasselskog, M. xi, 22, 67(n11), 68, 107, 306, 309(n1) 
healing (Cambodian society) 272, 281-4, 286

health/healthcare 155, 169, 178(n23), 181(n49), 191

Heder, S. 35-6, 68, 158, 184, 254, 262, 276, 293

Heng Mony Chenda 231, 233, 236

higher authorities 199, 207-8, 210, 213

Hughes, C. xi, 21, 27, 51, 57, 67(n2, n6, n8-9), 218(n9), 221, 228, 235-6, 248-9, 304-5

human rights $7,11,15$ (n11), 40, 87, 89, 92-4, 163, 171-2, 180(n43), 210, 232-6, 247, 252, 259, 266, 271, 287, 301

Human Rights Watch 89, 92, 97; 254, 257, 265, 294, 299

Hun Sen 32, 50-2, 54, 57-63, 285

consolidation of power 59; court

infrastructure 77; ECCC 253-5, 261-4, 267, 273-4, 278, 280, 288(n4), 290(n20); five years as Minister of Foreign Affairs (to 1985) 179(n38); good governance 156, 184, 180(n41); national sovereignty $180(\mathrm{n} 43)$; political economy of aid 160, 162-5, 168-9, 171, 179-81, 184; relations with judicial branch 80, 86, 87, 91, 93-4, 97(n13), 98-9; 'win-win' policy 273-4, 290(n26), 294

Huntington, S. 3, 14, 27, 298, 311

hybridity x, 20, 102, 111-12, 144-5, 297-312

identity 45, 137-8, 142, 144, 147-8, 149, 247, 309 ideology 39-40, 60, 74, 75, 123, 303

Ieng Sary 252, 256, 274, 276, 278, 288(n2)

Ieng Thirith 256, 274

IMF 8, 166-8, 172-3, 180(n46), 181(n51), 184

impunity 91-2, 251, 271, 275, 280, 285, 306, 308-9

Indochinese Communist Party 34, 268

inequality 153, 154, 158, 159, 165, 174

infant and child mortality 153-4, 157, 165, 177(n11), 179(n29)

inflation 151, 154, 155, 178(n21)

Internal Rules of ECCC (2007) 257-8, 288(n8)

International Centre for Transitional Justice 272, 290(n23, n28)

international community 266-9, 287-8, 290(n27), 308

International Conferences on Rehabilitation of Cambodia (ICORC, Tokyo, 1993, 1994) 154

international law 256-7, 269, 283, 305

international relations/foreign policy 156,159 , 162-3, 175, 262, 289(n13)

investigating judges/magistrates 90, 92, 276, 285 investment/investors 80, 90-1, 139, 178(n19)

Japan 171-2, 254, 260, 268-9, 290(n21)

judges 72-96, 96(n4, n8), 257-8, 278, 289(n9); fear of reprisal 92; insecurity of tenure 72, 93, 95; shortage 78, 89, 91; subservience 87-8

judicial independence 70-1, 93-5, 277 compromised 73-5, 79-80; intervention from executive branch 84-9; party detachment and political insularity 72 judicial reform/legal reform 90-4, 95, 269, 279-80

judicial salaries $81,91,96(n 9, n 12)$

judicial system 70-100, 298-9, 308

corruption 75, 81-4; flaws, 287; lack of resources 75-9, 89; legitimacy 89-94; politicized 88; 'tool for rich and powerful' 90 judiciary 250-2, 257, 269-70, 279-80, 306 appointments and promotions 83 ; and democracy 71-3; ECCC 274-7; educational attainment 78, 96(n9); history 74-5;

intra-institutional cooperation (low) 79-80; legitimacy 270; subservience 74-5, 79; women 136, 139

July events (1997) 153, 165, 166-8, 172, 177(n12), 178(n19), 254-5, 267-8

Kampong Cham 82, 241

Kampot province 67(n7), 263

Kandal Province 43, 100, 239, 244

Keat Chhon 156, 167, 184

Keo Sophoan 86, 97(n13), 98

Khieu Samphan 256, 263, 291(n31)

Khmer diaspora 245, 247, 282

Khmer Rouge 49, 87, 157, 168, 180(n39);

ECCC 250-96; insurgents (1980s, 1990s)

194; origins and outcomes 283

Khmer Rouge regime (1975-9) 1-2, 14, 17, 23, 25(n10), 45, 113, 154, 172, 305;

'closing the chapter' 268-70, 272, 280,

285-6; 192; lower-level cadres 254, 273-4, 290(n24); religion 224, 226, 231, 239, 243-4

Khmer Rouge Tribunal (KRT) 23, 288(n1); see also ECCC

Khmerness 38, 42, 44, 45, 47, 66

Kiernan, B. 38, 67(n4), 68

Kim Sedara xii-xiii, 22, 67(n2, n8), 68, 103, 114$15,117,119,122,124,130,133,218$ (n10, n17), 219(n18, n23-4), 220(n33), 222, 305

klach (fear) 117, 130(n14)

knowledge (new) 137, 142-4, 148

Koh Santepheap (newspaper) 86, 90-1, 97(n13), 98

'Kompong Loung' 191, 195-6, 200-2, 204-6, 208, 210, 212, 217(n3), 219(n19)

korob (respect) 117, 130(n14)

land 45, 58, 65, 94, 123, 174, 195, 200, 280, 299 
law 299

abolished by DK 74; 'subservient to political power' 89 ; 'two kinds' 92

law enforcement 79, 176(n6)

Law outlawing the DK group (1994) 274, 276-7, 294

lawyers $79,82-3,87-8,90,94,96(n 4)$ shortage 78

Ledgerwood, J. 43, 68, 105-6, 136, 140-1, 149

legitimacy 5-12, 16-23, 24(n3)

concept scrutinized 32; contested concept 19; democratic 31-3, 48, 62, 63; ECCC 25096; elections (1993-2008) 48-59; external $3, \mathbf{4}, 7,8, \mathbf{1 8}, 19,31,33,46,48,61-2,153,159$, 160-3, 173-5, 250, 252, 258, 260-1, 264-5, 268, 280; functional 53-4, 56-7, 60; general and particular application 17-20; internal 3, 4, 8, 17-18, 31, 49, 61-2, 153, 159, 160-3, $173,250,252,259-61,264-6,274,280,282$, 287; judicial system 89-94; key concept 16-17; 'multi-dimensional process' 18-19; national 286; procedural 32-3, 304; state machinery 125; 'three components' 19-20; during [Vietnam] War 42-8; Weberian definition 17, 264; women in politics 136-7; see also political legitimacy

liberal democracy 19, 119, 136, 189, 194, 218, 219(n22, n25), 301-2, 304-9 compatibility with local culture 308 ; 'inappropriate model' 16, 64, 130(n5)

LICADO xv, 89, 92, 97

Lilja, M. ii, xi-xii, 22, 70, 133, 136, 140-3, 146, $149,247,305,311$

local authorities 113, 192, 194-200

Local Development Fund (LDF) 193, 201-4, 213, 218(n7), 219(n21)

local leaders: perceptions of their roles 207-10

Local Planning Process (LPP) 193, 201

local politics 22, 122-4

logging 153, 165-7, 168-73, 262, 276

Lon Nol regime (1970-5) 1, 25(n10), 42-3, 113, 263

Long, W. J. 6, 13, 28

MacLeod, K. 218(n16), 219(n20, n26), 220(n301), 222

macroeconomy 154, 159, 167, 174, 177(n14), 181(n54)

Maha Ghosananda 228-9, 231, 240

Mahanikay (monastic order) 226, 233-4, 237, 242,244

'makeability' of a society $189,190,306$

Malloch Brown [initial/s n/a] 265, 295

mandates (village/commune level) 198, 200-5, 209, 213, 215, 218(n14)
Mansfield, C. 218(n16), 219(n20, n26), 220(n301), 222

Marston, J. xii, 22-3, 304-6

masculinity: 'hegemonic' (Connell) 142, 144

McAndrew, J. 218(n16), 219(n26), 220(n32), 222

McGrew, L. xii, 23, 289(n19), 295

media/newspapers/press $58,86-7,90-1,225$, 228, 264, 277-8, 299, 301

mekon (ranking monks at provincial level) 234, 235

mental health 277-8, 290-1(n30), 284, 287

militia/militiaman 113-14, 195, 197, 205, 207-8

ministries

Defence/National Defence 75, 180(n47);

Economy and Finance 121, 130(n8),

166; Foreign Affairs and International

Cooperation (MFAIC) 165; Interior (MoI)

75, 77, 79-80, 96(n8), 109-11, 121, 126,

178(n23), 213, 257, 259, 275-6; Justice

(MOJ) 74-5, 83, 84, 86, 87, 93, 96(n4),

257, 275; Religion (1992-) 227, 244; Rural

Development (MRD) 217(n2)

monarchy 20, 38-9, 42, 65, 224, 263-4

monks 205, 225-7, 231-5, 237-8, 239, 241-6,

248, 305-6

Montgomery, J. D. 4-5, 17, 29

'moral right to rule' $6,8,9,17,20,32-3,52,101$, 104, 129(n1)

National Army of Democratic Kampuchea 44, 49

National Assembly 34, 37, 75, 141, 158, 174, 180(n42), 256-7

National Election Committee (NEC) 52-4

National Institute of Public Health 177(n11), 179(n29)

national sovereignty $165,180(\mathrm{n} 43), 170,261$, 268,285

nation-building 25(n14), 46, 49, 114

neo-patrimonial relations 102, 119, 300, 307

nepotism 84, 90, 200, 207, 219(n27)

Nhem Kim Teng 231-3, 236

NICFEC 67(n3)

non-governmental organizations (NGOs) 155-6, $158,160,164,219$ (n23), 252, 258, 268-9, 277-80

impact (further research required) 148;

'inserted' 247; religion, 225, 227-31, 233-5,

239, 247-8; Western-funded 136-7, 145

'normality' 12-13, 159-65, 175, 307, 309

normative approach $8,25(\mathrm{n} 11)$

Norodom Ranariddh, Prince 160, 169, 177(n12), 254-5, 260, 262-3, 288(n4)

Norodom Sihamoni, King (2004-) 50, 263-4

Norodom Sihanouk

abdication (2004) 50; as King 34, 36, 56, 91 , 
93, 163, 227, 233, 256, 260, 263-4; as Prince 14, 20, 25-6(n16-17), 34, 36-42, 45, 61, 67(n10), 113, 266

nuns 229-30, 243, 248

Nuon Chea 256, 274

O’Donnell, G. 15, 28, 72, 98

Oam Yin Teang 86

oil 181(n52), 268

Öjendal, J. ii, xii, 22, 25(n16), 28-9, 68, 70, 103, $108,114-15,117,119,122,124,130-4$, 140, 149, 218-20, 222, 247, 298, 305, 311

Open Society Justice Initiative 289(n19), 290(n22), 291(n32), 295

Organic Law (drafted 2007) 26(n18), 130(n16)

Oudong 229, 238, 241-2, 246-7

Ovesen, J. 67(n5), 68, 138, 149

Pailin 158, 263, 290(n24), 283

Paris Peace Agreement (1991) 2, 46-7, 151, 154, 227-8, 240, 252, 261-2, 266, 271, 273, 299

Party of Democratic Kampuchea 48, 55-6

patronage politics/patronage $5,7,20,37,41,56$, 59, 71, 81-4, 85, 88, 90, 95, 105, 110-11, 121, 123-4, 130(n9), 155, 160-1, 165, 175, 269, 276; vertical 119

patron-client networks 81, 83, 94, 95, 253, 302, 305, 308

peace $51,60,104-5,127,192,270-1,273-4,282$, 285, 290(n24, n27)

peace-building 10, 55, 106, 108, 252

peasants $18,37,38,43,67$ (n10)

People's Republic of Kampuchea (PRK, 1979-) 44-8, 55, 79, 81, 96(n12), 252, 261, 273; judicial system 74; local authorities 199 , 218(n17); religion 224-8, 239

People's Revolutionary Party of Kampuchea 34

Peou Sorpong 289(n13), 295

Perez de Cuellar, J. 154

Phnom Penh 40-2, 57, 61, 63, 99-100, 179(n35), 196, 198, 238, 240-1, 244, 246, 256, 263 military battle (1997) 55; religion 231, 239-40, 243-4

Phnom Penh Municipal Court (PPMC) 75-7, 80, $83,87,90,96(\mathrm{n} 5-6)$

Pin Sisovann 163, 185

Pol Pot 46, 252, 261, 283, 288(n2)

police $38,59,61,73,80-1,86-7,90,96(n 2), 123$, 192, 259, 269-70, 277

'policy lists' 12-14

political authority 31-69, 101, 127-8

political culture 5, 103, 105, 109, 120, 130(n5), 305

political economy of aid 151-88

case studies 153, 165-73; context 154-9;

fieldwork 177(n9); qualitative input, 177(n9) political legitimacy 31-69; 103-6, 107, 151-88 decentralization reform 124-6; definition 176(n2); governance intervention 189-223; hybrid democracy and $~ 303-6$; postconflict context 297-312; reconstruction at commune level 114-24, 125-6; see also legitimacy

political parties $6,21,48,93,150,216,219(\mathrm{n} 26)$, 220(n32), 237, 242, 250, 253, 302-3

in opposition $52-6,60,73$; in opposition ('weakness') 53, 55-6; interference with judiciary 87-8; motives and interests in ECCC 262-3

political reconstruction versus 'conflict settlement' 107

decentralization reform as a means to $\sim$ 127-8; post-conflict society 1-30

political will 157, 180(n42), 260, 278, 287

politics 88, 130(n5), 299

competitive 4, 6; 'grey zone' (Carothers) 298, 300, 303-4, 307; of legitimacy and reconstruction (women) 136-50

post-conflict reconstruction ix-x, 303 application (general and particular) 10-14; approach, content, meaning 10; Cambodia as test-case 152; conclusions 307-9; decentralization strategy 101-35; democratic decentralization 'works well' 128-9; pillars 11; political 1-30; terminology 24(n2); time required for completion 14

poverty $22,31,81-2,108,118,121-2,123-5$, 127, 130(n7), 131(n18), 155, 178(n21), 180(n43), 206-7, 232, 275, 280, 308

poverty-reduction 157-8, 179(n30), 192, 263, 266,304

power $85,89,92,104,106,120,126,129(\mathrm{n} 3), 142$, 161, 178(n22), 264, 304-5, 307, 308-9

power structures: challenged by women 145-8; local 205-7

Pracheachon Party 34, 37

preah vihear 242

prosecutors 74, 76-82, 84-8, 90-6, 96(n4), 257-8, 276, 278, 285

fear of reprisal 92; insecurity of tenure 93,

95; shortage 91

'protection' 57, 64

protest 210-13, 214-15

provinces 54, 111, 121, 192, 202, 212

psycho-social services 282, 290-1(n30)

public outreach 259, 266, 269, 278, 280, 283-4, 286-7, 290-1(n30)

Pursat Province 43, 114

rational choice 200, 201, 219-20(n27) 
reconstruction and reconciliation ix, 14, 24 5(n6-9), 290, 308-9

reconciliation 6, 10, 105, 270-2, 273-4, 280, 281, 283-5, 287-8, 290(n24-5); reconstruction 2, 25(n10), 281, 297

Rectangular Strategy (RGC) 275

'reform through crisis' 167, 180(n45)

refugee camps 46-7, 227, 229-31, 239, 247

refugee repatriation $130(\mathrm{n} 6), 138,284$

refugees (IDPs/migration) 24(n8), 44-5, 177(n13)

'refusal of becoming' (Foucault) 147-8

regime legitimacy 24(n3), 151-88

foreign agendas 228; grass-roots 228-9;

politicization 47; state framework 225-7

reparations $276-7,280$

rich and powerful 71-2, 90, 92, 96(n2)

roads $50,65,77,171,201,204-5,219$ (n21)

Rondinelli, D.A. 4-5, 17, 29

Roome, P. 112, 113, 134

Royal Government of Cambodia (RGC) 155-6, 159-61, 166-70, 172, 174-5, 185, 286, 306 balancing acts 284-5; challenges 284-5; 'dismal human rights record' 287; ECCC 250, 253-4, 256, 258-64, 269-70, 272-4, 278-81, 282, 290(n20, n24); legitimacy 277-9; motives and interests in ECCC 2601; quest for legitimacy 260; 'understands donors better than donors understand RGC' 184; view of aid donors 163-5

Royal Government Task Force on the EC 274 rule of law 11, 18, 20-1, 70-5, 94-6, 152, 167, $253,265-6,270,275,277,279-80,282$, $286-8,306$; 'exists only on paper' 92

rural areas $43,45,65,155,157,162,193,204-5$, $214-17,245,308$;

governance intervention 191; participatory interventions 194; women 137-9, 141, 146, 147; see also communes

Rusten, C. 218(n9, n14), 219(n20-1, n23-4), 220(n29, 32), 222

Sam Bunthoeun 230, 238-9, 239-43, 247-8

Sam Rainsy Party (SRP) 33, 50, 53, 55-7, 60, 63, 65, 88, 130(n9), 137, 263, 285

'sanctity of tradition' 20

Sangkum era (1953-70) 20, 26(n17), 113

Sangkum Reastr Niyum (People's Socialist Community) 34, 36-42, 45, 53, 55

Santi Sena (1995-) 229-33

Sar Kheng 130(n7)

schools 40, 43, 44, 49, 50, 57, 65, 162, 219(n21)

Scott, J.C. 211-12, 222

security 49-50, 57, 60, 87, 155, 192-3, 259, 276, 285

SEILA (1996-) 108-9, 111, 130(n6), 191-3, 200,
204, 206, 213, 217-18(n6-7)

Senate 111, 126, 137, 162

Sihanoukism 38, 42, 46, 47, 50

Sisowath, King (1904-27) 112

socio-politics 210-13, 214, 216

Sok An 156, 178(n27), 180(n41), 185, 254, 256

Son Ngoc Thanh 38

Son Soubert 93, 100

Soviet Union/Soviet Bloc 46, 74, 154-5, 177(n15)

Special Drawing Rights (SDRs) 173, 181(n51)

sraouch touek (ritual blessing with water) 242, 243

State of Cambodia (SoC/SOC, 1989-) 47, 48, 75, $80,81,114,226,252$

Supreme Council of Magistracy (SCM) 80, 83, $87,93,264,270,275,277,288(n 2)$

Supreme Court 75, 76, 288(n2)

'Svay Ei' village 191, 195-6, 200-1, 205, 207-9, 211-12, 217(n3), 219(n19, n27)

Svay Rieng province 231, 233

Ta Mok (d 2006) 256

Task Force on Extraordinary Chambers (1999-) 256

taxation $77,108,111,113,152-3,160-1,165$, $167-8,172,174,176(\mathrm{n} 6), 247$

temples/pagodas/wat 49, 50, 57, 205, 207, 226, 233-5, 237-42, 244-6, 304-6

Tep Vong 226, 237

Thai border 44, 227, 229-31, 285

Thailand 37-8, 40, 46, 158, 237, 248, 267

Thammayut (monastic order) 226-7, 244

third wave of democratization (Huntington) 3 , 14, 27, 298, 311

Transcultural Psychosocial Organization (TPO) 290-1(n30)

transition paradigm (inadequacy) 298-300, 311

transitional justice 270-2

transparency/openness 103, 118, 121, 122, 1634, 167, 169, 180(n42), 185, 284

Transparency International (TI) 158, 179(n33-4)

trust/mistrust 6, 9, 70, 80, 90, 94, 96, 104-6, 118, $121,127,141,176(\mathrm{n} 8), 190,200,212$, 253-4, 265-6, 276, 281-2, 287-8

truth 270-1, 272-3, 274, 277, 280, 281, 283, 285, 290(n24)

Un, K. xiii, 21-2, 30, 79, 82-3, 90, 93, 96-100, 306

United Nations 1, 56, 166, 178(n26), 186, 308

Cambodia's seat 180(n39); Office of Legal

Affairs 254; Special Representative of

Secretary-General (SRSG) for Human

Rights in Cambodia 180(n43), 252, 268;

UN Border Relief Organization (UNBRO)

233-4; UN Committee on Elimination 
of Discrimination against Women 136, 139, 149; UN General Assembly 175; UN 'Group of Experts' 272, 282-3, 290(n24), 296; UN High Commissioner for Human Rights (Cambodia Office) 180(n43), 234, 252, 288(n4); UN Secretary General's report (2004) 271-2, 281, 296; UN Security Council 11, 162, 260, 268; UN Trust Fund 278, 290(n29); UN Volunteers 301; UNCDF xvi, 105; UNDP 11, 24(n8-9), 30, 108, 130 (n6), 135, 192, 217(n2); UNICEF 177(n11

United States of America 11, 31, 63, 164, 166, 173, 177(n13), 181(n50), 234, 240, 245-6, 253-4, 260, 266-8, 290(n20), 299

US Congress 178(n24), 268; USAID 152, 158, 178(n24)

UNTAC 2, 5, 8, 9, 20-1, 22, 25(n12, n15), 48, 51, 109, 130(n6), 152, 154, 158-9, 162-3, 173-4, 178(n19), 179(n30), 192, 251, 266-7, 271, 284, 301, 309(n1), 310 criminal law 252; human rights 234; legacy 180(n43); religion 224-5, 227-9, 234, 237, 240, 247

Vickery, M. 67(n4), 68, 74, 99

Vietnam 25(n16), 36, 40, 46, 66, 168, 226, 231, 240, 253, 262, 266-8, 284, 289-90(n1920), 299

Vietnamese 45, 64, 113-14, 261

Vietnamese invasion (1978-9) 2, 44, 162

Vietnamese withdrawal (1989) 75, 114, 154, 226

Vietnamization 46, 47, 50, 54, 74

village autarky 42, 46, 67(n3)

village chiefs $52-3,55,57,65,111,123,126$, 130(n15), 192, 195-9, 201-2, 205-6, 208, 217-20n; arbitrariness 199; remuneration 220(n28)

Village Development Committees (VDCs) 193, 200-1, 208, 218(n7-8) elections 206-7, 213; membership/members 205-6, 209, 212; roles and responsibilities 202, 219(n20)

Village Development Plan (VDP) 193, 203 perceptions of development 200-5; perceptions of local authorities 194-200

villages $39-47,49,52-3,55,57-8,61,67$ (n10),

192, 283

leadership challenges 210-13; power structures 41; procedures not understood by villagers 198, 199; subsistence 41, 45

weak states 176(n6), 185

Weber, M. 17, 30

Westernization 138-9, 144-5, 148

women 18, 22, 199, 202, 206-7, 217(n2), 219(n24), 302, 305, 308-9

challenging power structures 145-8; decision-making power 147; high-status knowledge 142-4; literature 140; political participation 136-50; and politics 139-42; representation in parliament 139; resistance strategies 138, 142-5, 148; self-confidence 143; status 140-1, 143-4; VDCs 193; see also nuns

World Bank 8, 11, 90, 152, 159, 166, 170, 176-9n; author-data source 157-8, 165, 172-3, 179(n30, n32), 180(n46), 186-7, 275, 296; expenditure tracking 181(n49); reports on Cambodia (1994-7) 178(n18), 186

World Development Indicators 177(n11), 179(n29)

World Trade Organization 162, 261

'woven discourses' 144-5

Yos Hut 233-4, 240

Young, I. 299-300, 306, 312

youth 35, 38, 40-1, 65, 277

Yun Samean 171, 188

NIAS Press is the autonomous publishing arm of NIAS - Nordic Institute of Asian Studies, a research institute located at the University of Copenhagen. NIAS is partially funded by the governments of Denmark, Finland, Iceland, Norway and Sweden via the Nordic Council of Ministers, and works to encourage and support Asian studies in the Nordic countries. In so doing, NIAS has been publishing books since 1969, with more than two hundred titles produced

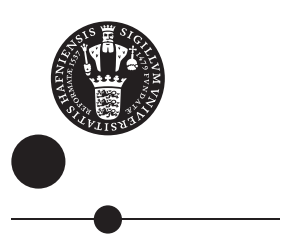

COPENHAGEN UNIVERSITY

in the past few years.

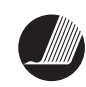

\section{nordon}

Nordic Council of Ministers 